\title{
Environmental Monitoring Plan for Waste Area Grouping 6 at Oak Ridge National Laboratory, Oak Ridge, Tennessee
}

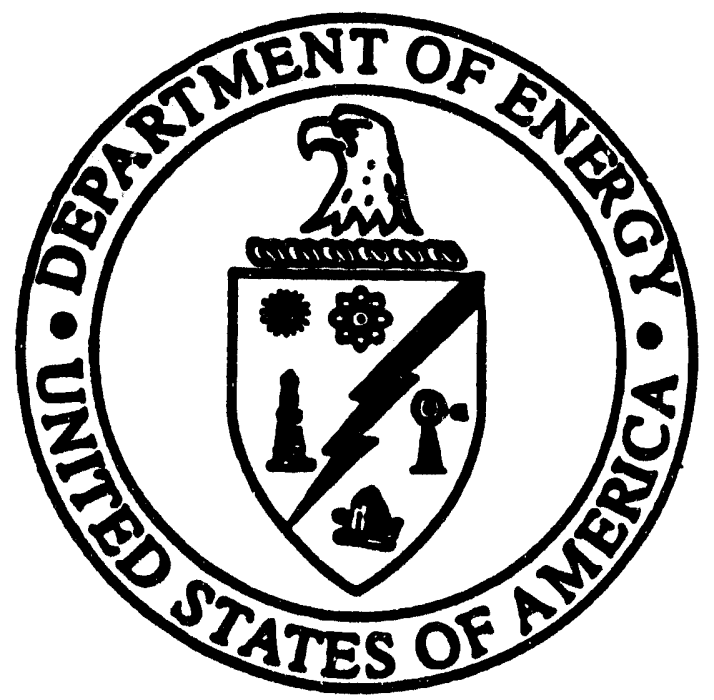


DOE/OR/01-1192\&D1

ORNL/ER-158\&D1

Energy Systems Environmental Restoration Program ORNL Environmental Restoration Program

\section{Environmental Monitoring Plan for Waste Area Grouping 6 at Oak Ridge National Laboratory, Oak Ridge, Tennessee}

Date Issued-September 1993

Prepared by

Science Applications International Corporation

Oak Ridge, Tennessee

under subcontract 18B-99069C

Prepared for

U.S. Department of Energy

Office of Environmental Restoration and Waste Management under budget and reporting code EW 20

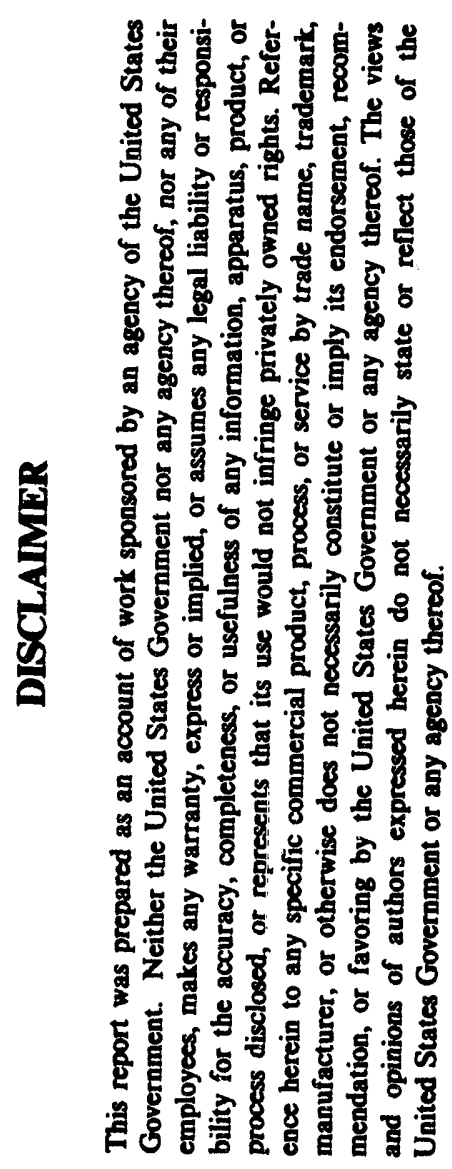

OAK RIDGE NATIONAL LABORATORY

Oak Ridge, Tennessee 37831-6285

managed by

MARTIN MARIETTA ENERGY SYSTEMS, INC.

for the

U.S. DEPARTMENT OF ENERGY

under contract DE-AC05-84OR21400 


Environmental Consulting Engineers, Inc.
EBASCO Services
CDM Federal Programs Corporation
Science Applications International Corporation
Radian Corporation
Gilbert/Commonwealth Engineers and Consultants
contributed to the preparation of this document and
should not be considered eligible contractors for its
review.




\section{CONTENTS}

FIGURES $\ldots \ldots \ldots \ldots \ldots \ldots \ldots \ldots \ldots \ldots \ldots \ldots \ldots \ldots \ldots \ldots \ldots \ldots \ldots$

TABLES $\ldots \ldots \ldots \ldots \ldots \ldots \ldots \ldots \ldots \ldots \ldots \ldots \ldots \ldots \ldots \ldots \ldots \ldots \ldots \ldots$ vii

ACRONYMS $\ldots \ldots \ldots \ldots \ldots \ldots \ldots \ldots \ldots \ldots \ldots \ldots \ldots \ldots \ldots \ldots \ldots \ldots$ ix

EXECUTIVE SUMMARY $\ldots \ldots \ldots \ldots \ldots \ldots \ldots \ldots \ldots \ldots \ldots \ldots \ldots \ldots$ xi

1. INTRODUCTION $\ldots \ldots \ldots \ldots \ldots \ldots \ldots \ldots \ldots \ldots \ldots \ldots \ldots \ldots$ 1-1

1.1 PURPOSE AND SCOPE OF DOCUMENT $\ldots \ldots \ldots \ldots \ldots \ldots \ldots \ldots \ldots$

1.2 ENVIRONMENTAL RESTORATION (ER) PROGRAM STRATEGY $\ldots \ldots \ldots 1-2$

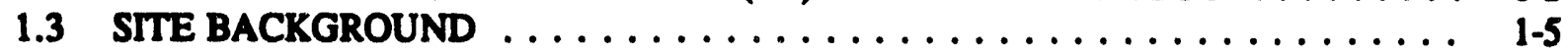

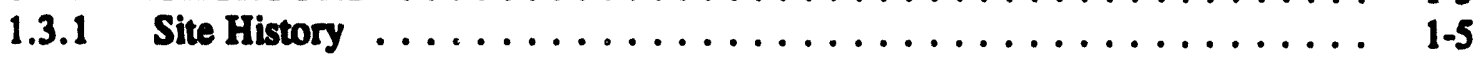

1.3.2 Regulatory Background $\ldots \ldots \ldots \ldots \ldots \ldots \ldots \ldots \ldots \ldots, 1-5$

1.3.3 Overview of the RFI $\ldots \ldots \ldots \ldots \ldots \ldots \ldots \ldots \ldots \ldots \ldots$ 1-7

2. MONITORING OBJECTIVES $\ldots \ldots \ldots \ldots \ldots \ldots \ldots \ldots \ldots \ldots \ldots \ldots$ 2-1

2.1 PROGRAM OBJECTIVES $\ldots \ldots \ldots \ldots \ldots \ldots \ldots \ldots \ldots \ldots \ldots$ 2-1

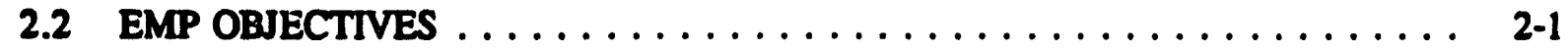

2.3 DATA QUALTTY OBJECTIVES $\ldots \ldots \ldots \ldots \ldots \ldots \ldots \ldots \ldots \ldots$ 2-2

2.3.1 Statement of the Problem $\ldots \ldots \ldots \ldots \ldots \ldots \ldots \ldots \ldots \ldots, 2-7$

2.3.2 Identify the Decisions to be Made ................ 2-7

2.3.3 Identify Inputs to the Decision (Data Users $\ldots \ldots \ldots \ldots \ldots \ldots \ldots$ 2-9

2.3.4 Define the Study Boundaries $\ldots \ldots \ldots \ldots \ldots \ldots \ldots \ldots \ldots \ldots$ 2-9

2.3.5 Develop the Decision Rule $\ldots \ldots \ldots \ldots \ldots \ldots \ldots \ldots \ldots \ldots . . \ldots$ 2-9

2.3.6 Specify Limits on Uncertainty $\ldots \ldots \ldots \ldots \ldots \ldots \ldots \ldots \ldots \ldots$ 2-11

2.3.7 Optimize Design for Obtaining Data $\ldots \ldots \ldots \ldots \ldots \ldots \ldots \ldots$ 2-12

3. ENVIRONMENTAL MONITORING TASKS $\ldots \ldots \ldots \ldots \ldots \ldots \ldots \ldots$ 3-1

3.1 SAMPLING AND ANALYSIS FRAMEWORK $\ldots \ldots \ldots \ldots \ldots \ldots \ldots$ 3-1

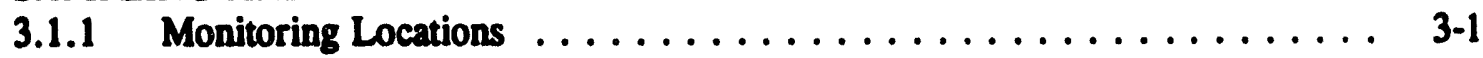

3.1.2 Sample Collection Methods ................... 3-12

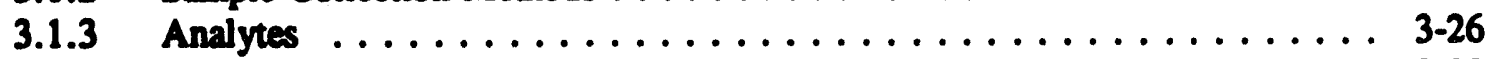

3.2 SAMPLING AND ANALYSIS PLAN $\ldots \ldots \ldots \ldots \ldots \ldots \ldots \ldots \ldots \ldots \ldots \ldots \ldots$

3.2.1 PO1 - Evaluate Changes in Risk Attributable to WAG 6 . . . . . . . . 3-34

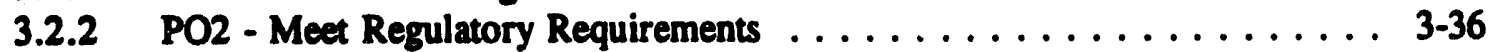

3.2.3 PO3 - Support Implementation of Interim or Final Actions $\ldots \ldots \ldots \ldots$ 3-37

4. DATA ANALYSIS AND RISK ASSESSMENT $\ldots \ldots \ldots \ldots \ldots \ldots \ldots \ldots$ 4-1

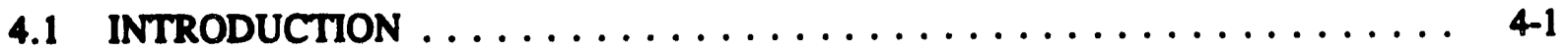

4.2 DATA MANAGEMENT . . . . . . . . . .

4.3 METHODS TO EVALUATE CHANGES IN RISK CONDITIONS $\ldots \ldots \ldots \ldots$ 4-1

4.3.1 Risk to the Receptor at the Boundary of the Waste Unit ......... 4-2

4.3.2 Relative Risk from WAG 6 at WOD ............... 4-4

4.3.3 Contaminant Trend Analysis . . . . . . . . . . . . . . 4-9

4.4 METHODS TO IDENTIFY CHANGES IN COCs . . . . . . . . . . . 4-10

4.4.1 Inorganic and Organic Contaminants . . . . . . . . . . . 4 411

4.4.2 Radionuclides ........................ 4-11

4.4.3 Methods for Identifying COCs to be Deleted from the List . . . . . . . 4 4-11 
5. PROGRAM STRATEGY AND ADMINISTRATION $\ldots \ldots \ldots \ldots \ldots \ldots \ldots \ldots$ 5-1

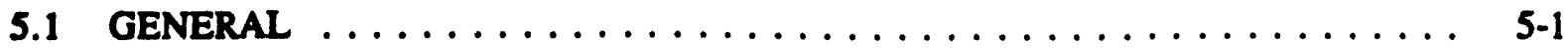

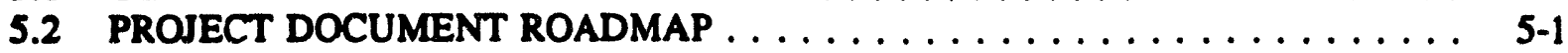

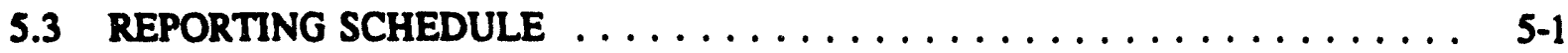

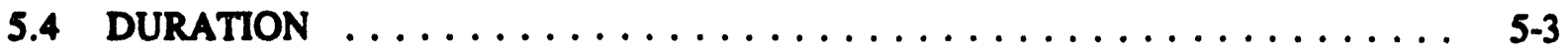

6. REFERENCES

6-1

7. GLOSSARY OF TERMS

$7-1$

APPENDIXES

A PRELIMINARY CALCULATION OF RELATIVE RISK AT WHITE OAK DAM $\ldots \ldots$ A-1

B PARC PARAMETERS

B-1

C ESTIMATION OF ANNUAL H FLUX AND AVERAGE CONCENTRATION FROM WAG 6 SURFACE WATER USING THE QC MODEL $\ldots \ldots \ldots \ldots \ldots \ldots \ldots$. . .

D CHEMICAL OF CONCERN SELECTION CRITERIA $\ldots \ldots \ldots \ldots \ldots \ldots \ldots \ldots$

93-072P/090993

iv 


\section{FIGURES}

1.1 Contaminant discharge to WOD $\ldots \ldots \ldots \ldots \ldots \ldots \ldots \ldots \ldots \ldots$

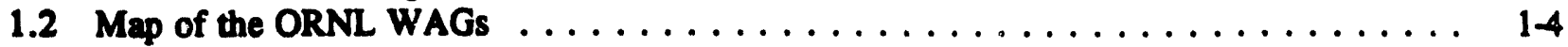

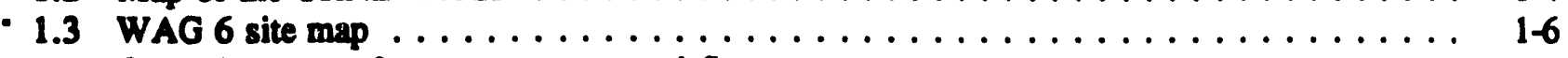

1.4 Groundwater-surface water conceptual flow system . . . . . . . . . . . . . . . $1-9$

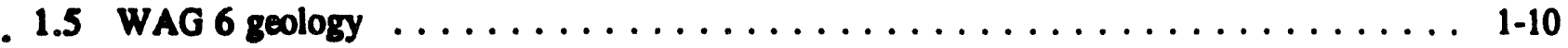

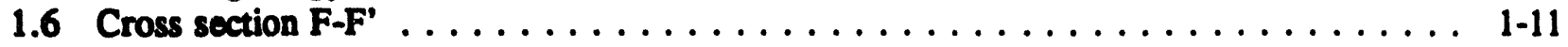

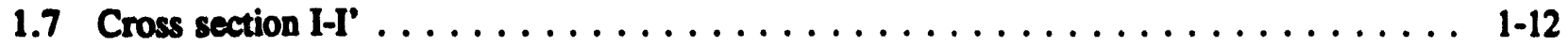

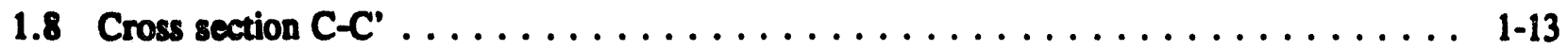

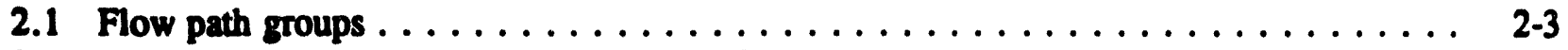

2.2 Subsurface flow paths along ungaged WAG 6 perimeter . . . . . . . . . . . . $2-6$

2.3 WAG 6 DQO development process $\ldots \ldots \ldots \ldots \ldots \ldots \ldots \ldots \ldots \ldots \ldots \ldots$

2.4 WAG 6 conceptual monitoring strategy . . . . . . . . . . . . . . . . . 2-13

2.5 Summary of WAG 6 monitoring plan strategy $\ldots \ldots \ldots \ldots \ldots \ldots \ldots \ldots \ldots$

3.1 WAG 6 watersheds and surface water monitoring stations $\ldots \ldots \ldots \ldots \ldots \ldots \ldots \ldots$

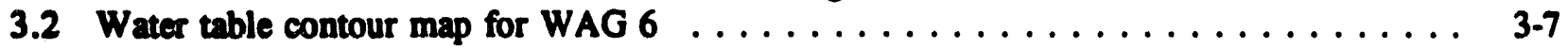

3.3 Locations of groundwater quality monitoring wells $\ldots \ldots \ldots \ldots \ldots \ldots \ldots$

3.4 Location of non-trench piezometers and wells $\ldots \ldots \ldots \ldots \ldots \ldots \ldots \ldots$

3.5 Location of trench piezometers and wells $\ldots \ldots \ldots \ldots \ldots \ldots \ldots \ldots \ldots \ldots$

3.6 Hydrologic classes of trenches at WAG $6 \ldots \ldots \ldots \ldots \ldots \ldots \ldots \ldots \ldots \ldots$

4.1 Decision tree ................................ 4-12

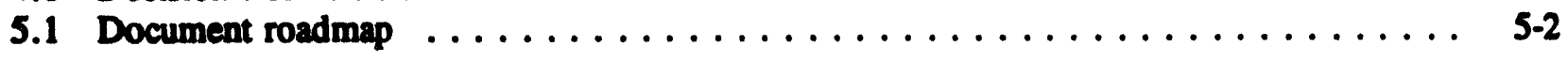




\section{TABLES}

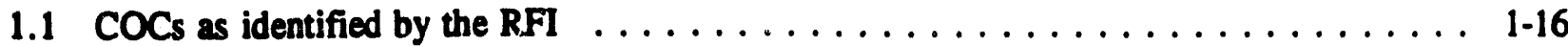

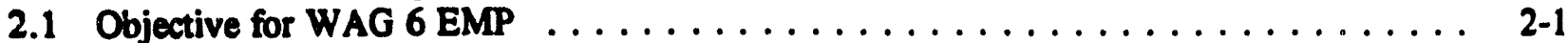

- 2.2 Water volume by flow path $\ldots \ldots \ldots \ldots \ldots \ldots \ldots \ldots \ldots \ldots \ldots \ldots \ldots \ldots \ldots, 2-5$

2.3 Summary of WAG monitoring data needs $\ldots \ldots \ldots \ldots \ldots \ldots \ldots \ldots \ldots \ldots \ldots$ 2-10

3.1 Gaged surface water monitoring stations $\ldots \ldots \ldots \ldots \ldots \ldots \ldots \ldots \ldots \ldots \ldots, 4$

3.2 Ungaged surface water monitoring locations $\ldots \ldots \ldots \ldots \ldots \ldots \ldots \ldots \ldots$ 3-5

3.3 Wells to be sampled for groundwater quality $\ldots \ldots \ldots \ldots \ldots \ldots \ldots \ldots$ 3-9

3.4 Approximate locations of the proposed groundwater quality monitoring wells $\ldots \ldots \ldots \ldots \ldots \ldots \ldots \ldots \ldots \ldots \ldots \ldots \ldots \ldots \ldots . \ldots \ldots$

3.5 Perimeter groundwater quality monitoring well data $\ldots \ldots \ldots \ldots \ldots \ldots \ldots$ 3-10

3.6 Interior groundwater quality monitoring well data $\ldots \ldots \ldots \ldots \ldots \ldots \ldots \ldots$ 3-11

3.7 Data for existing piezometers and monitoring wells $\ldots \ldots \ldots \ldots \ldots \ldots \ldots \ldots$ 3-13

3.8 Proposed new non-trench piezometer locations $\ldots \ldots \ldots \ldots \ldots \ldots \ldots \ldots$ 3-17

3.9 WAG 6 trench piezometer hydrologic class $\ldots \ldots \ldots \ldots \ldots \ldots \ldots \ldots \ldots \ldots$ 3-18

3.10 WAG 6 trench monitoring piezometer data $\ldots \ldots \ldots \ldots \ldots \ldots \ldots \ldots$ 3-19

3.11 Wells to be equipped for continuous monitoring $\ldots \ldots \ldots \ldots \ldots \ldots \ldots \ldots$ 3-21

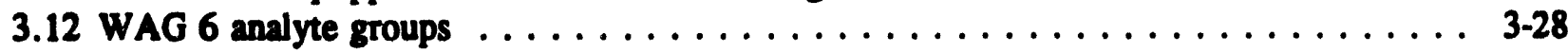

3.13 Summary of WAG 6 SAP $\ldots \ldots \ldots \ldots \ldots \ldots \ldots \ldots \ldots \ldots \ldots . \ldots \ldots$. $\ldots \ldots \ldots$

4.1 Tiered approach for transport pathway component quantification $\ldots \ldots \ldots \ldots \ldots$ 46

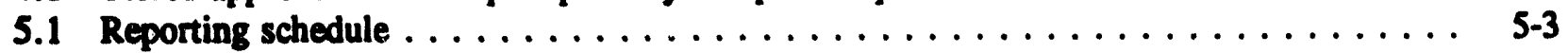




\section{ACRONYMS}

2-D

-3-D

ACF

. AMR

ARARs

CERCLA

CLP

COC

C-Q

DOE

DQO

EDT

EMP

Energy Systems

EPA

ER

ET

EWB

FFA

FWS

GC

HEAST

HI

HSL

- ICM

IRIS

LLW

MCL

NCOC

NCP

NPDES

NPL

OREIS

ORNL

ORR

OU

PARCC

PO

POC

PRC

PVC

QAPjP

QAP

QA/QC

RC

- RCRA

RFI

two-dimensional

three-dimensional

annual contaminant flux

Annual Monitoring Report

Applicable, Relevant, and Appropriate Requirements

Comprehensive Environmental Response, Compensation and Liability Act

Contract Laboratory Program

chemical of concern

concentration-discharge relationship

U.S. Department of Energy

data quality objectives

Explosives Detonation Trench

Environmental Monitoring Plan

Martin Marietta Energy Systems, Inc.

U. S. Environmental Protection Agency

environmental restoration

evapotranspiration

Emergency Waste Basin

Federal Facilities Agreement

U.S. Fish and Wildlife Service

geochemical

Health Effects Assessment Summary Tables

hazard index

Hezardous Substance List

Interim Corrective Measures

Integrated Risk Information System

low-level radioactive waste

maximum contaminant level

new chemicals of concern

National Contingency Plan

National Pollutant Discharge Elimination System

National Priorities List

Oak Ridge Environmental Information System

Oak Ridge National Lahoratory

Oak Ridge Reservation

operable unit

Precision, Accuracy, Representativeness, Completeness, and Comparability

primary objectives

point of compliance

primary risk contributors

polyvinyl chloride

Quality Assurance Project Plan

Quality Assurance Plan

quality assurance/quality control

relative contribution

Resource Conservation and Recovery Act

RCRA Facility Investigation 


$\begin{array}{ll}\text { RFICOC } & \text { RFI chemicals of concern } \\ \text { RI } & \text { remedial investigation } \\ \text { RS } & \text { radiological scans } \\ \text { SAP } & \text { Sampling and Analysis Plan } \\ \text { SARA } & \text { Superfund Amendments and Reauthorization Act } \\ \text { SDWA } & \text { Safe Drinking Water Act } \\ \text { SOW } & \text { statement of work } \\ \text { SWSA } & \text { Solid Waste Storage Area } \\ \text { TAL } & \text { Target Analyte List } \\ \text { TCL } & \text { Target Compound List } \\ \text { TDEC } & \text { Tennessee Department of Environment and Conservation } \\ \text { UCL } & \text { upper confidence level } \\ \text { VOCs } & \text { volatile organic compounds } \\ \text { WAG } & \text { Waste Area Grouping } \\ \text { WOC } & \text { White Oak Creek } \\ \text { WOD } & \text { White Oak Dam } \\ \text { WOL } & \text { White Oak Lake } \\ \text { WST } & \text { West Seep Tributary } \\ \text { WSW } & \text { West Seep Weir }\end{array}$




\section{EXECUTTVE SUMMARY}

This document presents the Environmental Monitoring Plan (EMP) for Waste Area Grouping (WAG) 6 at the Oak Ridge National Laboratory (ORNL). Based on the results of the Resource Conservation and Recovery Act (RCRA) Facility Investigation (RFI) and on subsequent discussions with regulators, a

- decision was made to defer implementing source control remedial measures at the WAG. The alternative selected to address the risks associated with WAG 6 involves maintenance of site access controls to prevent public exposure to on-site contaminants, continued monitoring of contaminant releases to determine if source control measures are required, and development of technologies that could support the final remediation of WAG 6.

The decision to defer active source control measures at WAG 6 is based primarily on information that shows WAG 6 contributes $<2 \%$ of the total off-site contaminant risk released over White Oak Dam (WOD). Thus, while WAG 6 may require source control measures in the future, available resources are currently being shifted to higher priority sites, e.g., those source WAGs that contribute a greater percentage to off-site risk.

Although active source control measures are not being implemented at WAG 6, environmental monitoring is necessary to ensure that any potential changes in contaminant release from the WAG are identified early enough to take appropriate action. Two types of environmental monitoring will be conducted: baseline monitoring and annual routine monitoring. The baseline monitoring will be conducted to establish the baseline contaminant release conditions at the WAG, confirm the site-related chemicals of concern (COCs), and gather data to confirm the site hydrologic model. The baseline monitoring is expected to begin in 1994 and last for 12-18 months. The annual routine monitoring will consist of continued sampling and analyses of COCs to determine off-WAG contaminant flux and risk, identify trends in releases, and confirm the primary contributors to risk. The annual routine monitoring will continue for $\sim 4$ years after completion of the baseline monitoring.

The following sampling/monitoring activities will be conducted during both phases of the EMP to support the previously stated goals: surface water monitoring at gaged sites and along the ungaged perimeter of the site; surface water monitoring to evaluate the concentration $(C)$ vs volumetric flow rate (Q) relationship (C-Q); groundwater perimeter monitoring; interior well monitoring; groundwater level monitoring; seep and spring monitoring; 49 trench area French drain discharge monitoring; and meteorological monitoring. Data quality objectives (DQOs) have been established to ensure that a twofold increase in annual risk from contaminant flux from WAG 6 can be identified. A factor of 2 increase in risk from WAG 6 releases each year for a period of 4 years would increase WAG 6 contribution to risk at WOD to a level that would make it a priority site for source control measures. Identifying a twofold annual increase will help ensure that appropriate actions can be taken before off-site risks reach an unacceptable level. 


\section{INTRODUCTION}

\subsection{PURPOSE AND SCOPE OF DOCUMENT}

This document outlines the purpose and objectives of the Environmental Monitoring Plan (EMP) at the Oak Ridge National Laboratory (ORNL) Waste Area Grouping (WAG) 6. Based on the results of the Resource Conservation and Recovery Act (RCRA) Facility Investigation (RFI) conducted from 1989-1991 (BNI 1991), and on recent interactions among the U.S. Department of Energy (DOE), the U.S. Environmental Protection Agency (EPA) and the Tennessee Department of Environment and Conservation (TDEC), a decision was made to defer implementing source control remedial measures at the WAG. The alternative selected to address hazards at WAG 6 involves maintenance of site access controls to prevent public exposure to on-site contaminants, continued monitoring of contaminant releases to determine if source control measures are required, and development of technologies that could support the final remediation of WAG 6.

The decision to defer active control measures at WAG 6 is based primarily on information that shows WAG 6 contributes $<2 \%$ of the total off-site contaminant risk released over White Oak Dam (WOD). Thus, while WAG 6 source control measures may be required at some time in the future, available resources are currently being shifted to higher priority sites, e.g., those WAGs that contribute a greater percentage to off-site risk.

Although active source control measures are not being implemented at WAG 6, it is necessary to ensure that any major increases in contaminant release from the WAG are identified early enough to take appropriate action. Because WAG 6 was established later than other WAGs, it is early in its release history compared to other WAGs, and thus current releases may not be indicative of future releases. Monitoring at WAG 6 is the method chosen to ensure that changes in releases are tracked and identified - before they reach a magnitude comparable to other sources.

The WAG 6 EMP is also designed to address all applicable regulatory requirements. Current regulatory drivers at the site include a tri-party letter agreement between DOE, EPA Region IV, and the TDEC Comprehensive Environmental Response, Compensation, and Liability Act (CERCLA) programs; and RCRA, National Pollutant Discharge Elimination System (NPDES) compliance permits, and relevant DOE orders.

The WAG 6 EMP is also designed (1) to contribute to a better understanding of pathways and processes important for contaminant transport in the White Oak Creek (WOC) watershed, (2) to provide information to support a final remedy for WAG 6 and the groundwater operable unit (OU), (3) to gain insight into the development and implementation of a focused and effective monitoring program conducted when remedial actions are deferred, (4) to support the Melton Valley groundwater model development, and (5) to determine the accuracy and reliability of the existing site hydrologic (water balance) model as part of the broader ORNL conceptual model.

Although the major aspects of the plan are presented in this report, many of the details will be presented in associated documents, including a stand-alone Sampling and Analysis Plan (SAP), Quality Assurance Project Plan (QAPjP), Health and Safety Plan, and a Data Management Plan. These plans are outlined in more detail in Sect. 5. 


\subsection{ENVIRONMENTAL RESTORATION (ER) PROGRAM STRATEGY}

The WAG 6 EMP is a subset of the ER Program for the entire ORNL site. As such, any environmental monitoring plan for the WAG must conform to the ER site-wide strategy for ORNL. Although the site-wide strategy is in early stages of development, major aspects have been identified, including:

- support rapid reduction of risk to human health and the environment;

- reduce contaminant releases offsite via WOC and Raccoon Creek;

- address the major sources of contaminant releases in a prioritized and hierarchical fashion, addressing sites of greatest concern (risk, regulatory, public) first;

- identify source control actions that result in a significant reduction of risk or contaminant flux; and

- collect data necessary to design, implement, and verify final remedies.

The current strategy does not address the technical and conceptual details of managing the integration of source WAGs and environmental media WAGs (i.e., the groundwater OU). Initial work at the site indicates that early phases of CERCLA implementation at the WOC watershed should focus on understanding the major contributors to releases over WOD. The ORNL ER Program prioritizes these major contributors largely via efforts in WAG 2. Figure 1.1 shows how WAG 6 fits into the conceptual understanding of current off-site releases via WOD. Contamination at WOD comes from four primary sources: directly from WAG 6 and WAG 7 via WAG 2, and from sources that release contaminants into WOC and Melton Branch Creek (Fig. 1.2). Monitoring performed on the major drainages leading to White Oak Lake (WOL) and WOD suggests that contaminant flux from WAG 6 and WAG 7 is minimal compared to the flux coming from sources along WOC and Melton Branch, suggesting WAG 6 and WAG 7 are low priority risk sources.

The focus of the WAG 6 EMP will be on tracking changes in the total flux and risk contributions from WAG 6 to WOD, to provide the ER Program necessary information to continue to track and identify source control priorities. The plan assumes that the hypothetical point of exposure [point of compliance (POC)] is WOD. WOD would not be considered a conventional POC for CERCLA activities. However, this EMP is designed to track WAG 6 releases for near-term decision-making on prioritizing source control activities at ORNL. The WOD POC provides the reference point for determining the worst contributors to off-site risk first. Another type of decision-making will occur when it is necessary to determine final cleanup goals for source WAGs. Depending on resolution of land use issues, the POC may still be WOD or may be WOL or the tributaries flowing into the lake. However, because the major objective of the WAG 6 EMP is to determine when WAG 6 will become a higher priority site, the POC is WOD.

In addition to tracking risk contribution at the dam, data will be collected and analyzed in a manner that provides information on the risk to a hypothetical person residing at the boundary of the waste unit. The boundary of the waste unit is the conventional POC for RCRA and CERCLA actions. RFI risk estimates for a future hypothetical person residing on-WAG indicated access controls are necessary to 


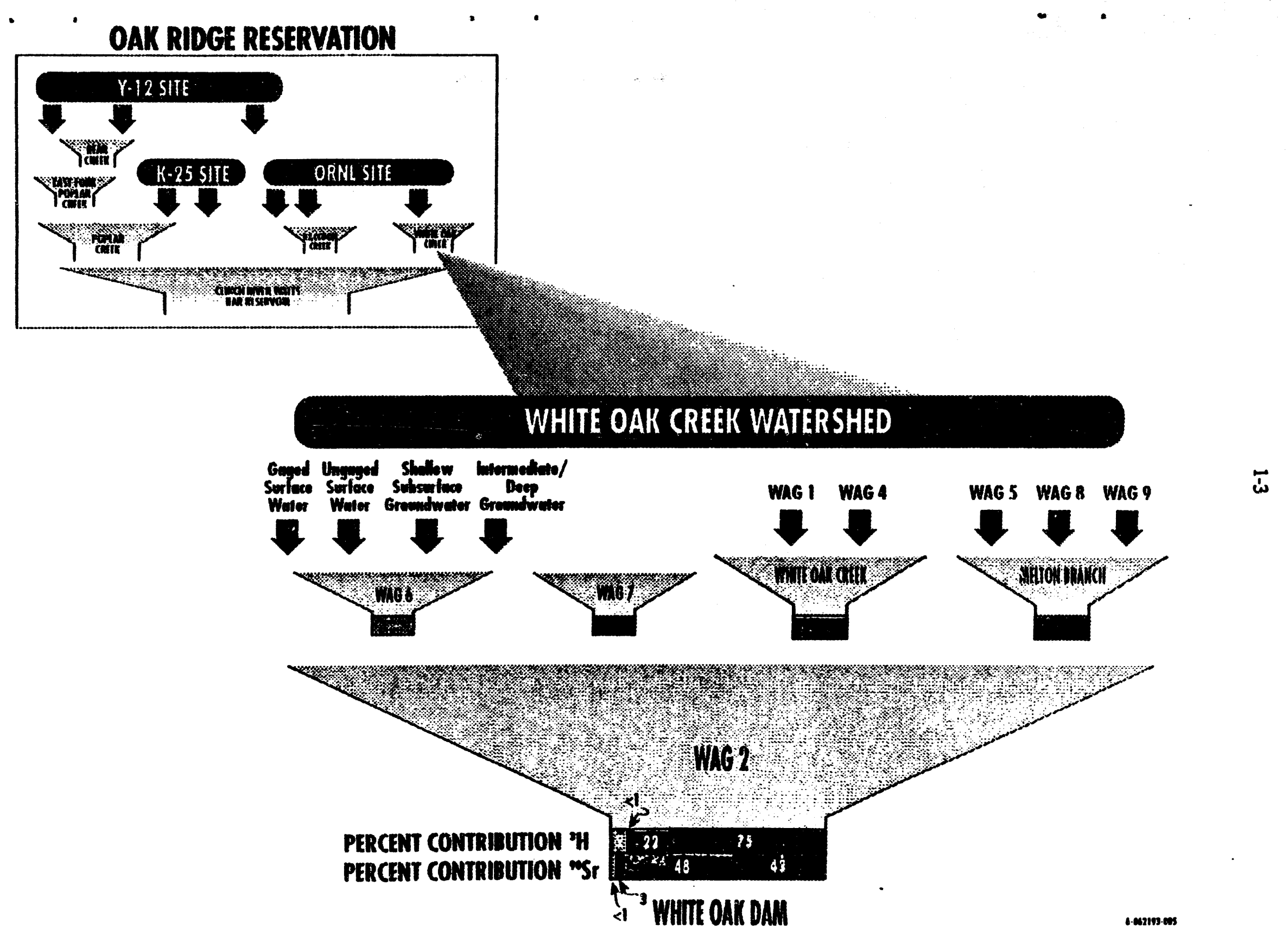

Fig. 1.1. Contaminant discharge to WOD. 


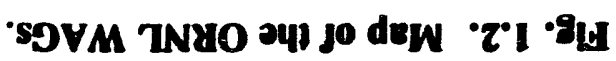

musoo isomolrsorol.o

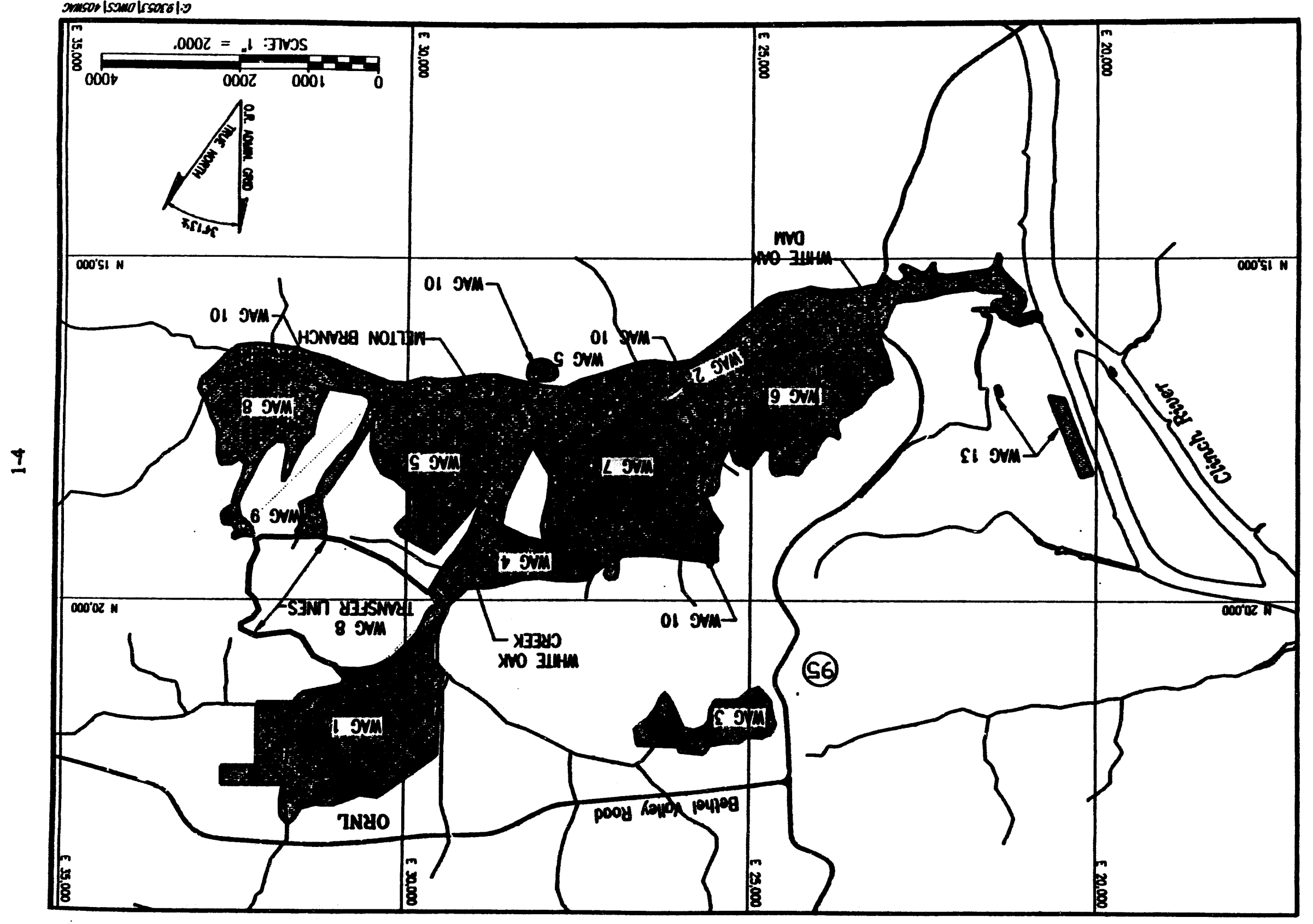


prevent on-WAG exposures. Changes in risk estimated for the WAG boundary will be evaluated to satisfy regulatory concerns and to reiterate the need for continued access controls of the WAG.

Because the major objective of the monitoring is to track changes in risk and flux, the EMP is divided into two primary components: baseline monitoring and routine annual monitoring.

The baseline monitoring is estimated to take 12-18 months to complete. The baseline characterization is intended to provide the data necessary to confirm the findings of the RFI with respect to off-site transport of chemicals of concern (COCs); establish baseline flux and risk estimates against which routine annual monitoring results can be compared; provide input into directed study activities; and obtain information to assist in refining the EMP for continued routine annual sampling. Results of the baseline monitoring will be used to identify the initial conditions at the site and provide input into the routine monitoring component so that routine monitoring can be focused and cost-effective.

The routine annual monitoring will begin in parallel with the baseline monitoring. Routine annual monitoring is interded to provide the information necessary to calculate annual changes in contamination releases and risk associated with WAG 6. Routine annual monitoring will continue at the site for 5 years.

\subsection{SITE BACKGROUND}

\subsubsection{Site Fistory}

Martin Marietta Energy Systems, Inc. (Energy Systems), under prime contract to DOE, operates the three facilities on the Oak Ridge Reservation (ORR), including ORNL. As part of research operations

- at ORNL, hazardous and low-level radioactive waste (LLW) have been produced and disposed of for 45 years. WAG 6, which has received waste since 1969, consists of three solid waste management units: Solid Waste Storage Area (SWSA) 6, the Emergency Waste Basin (EWB), and the Explosives

- Detonation Trench (EDT). These units are shown in Fig. 1.3. The EWB, located in the northeast corner of WAG 6, is an emergency holding basin with a surface area of $\sim 0.8$ ha $(2$ acres) and a storage capacity of $15 \mathrm{M}$ gal. The basin has never been used for waste disposal or storage but does receive some runoff from SWSA 6. The EDT was a trench $~-15-f t$ long, 5-ft wide, and 4-ft deep and was used to detonate explosives and shock-sensitive chemicals. The EDT was located in the southeastern corner of SWSA 6 but has been backfilled and its exact location is unknown (BNI 1991).

SWSA 6, comprising $~ 27.5$ ha (68 acres), was opened in 1969 for shallow land burial of LLW and nonradioactive wastes. Wastes disposed of in SWSA 6 include laboratory glassware and equipment, protective apparel, mechanical equipment, construction materials, filter media and resins, contaminated earth, biological research wastes, etc. Waste packaging has been highly variable ranging from plastic bags to stainless steel drums to unpackaged waste (BNI 1991).

\subsubsection{Regulatory Background}

SWSA 6 was operated under the authority of the Atomic Energy Act of 1954, as administered under

- the guidance of the Atomic Energy Commission (now known as DOE) for managing radioactive waste materials. In May 1986, DOE temporarily discontinued waste disposal at SWSA 6 when it was discovered that RCRA-regulated hazardous and/or mixed wastes were being disposed of there. Once 


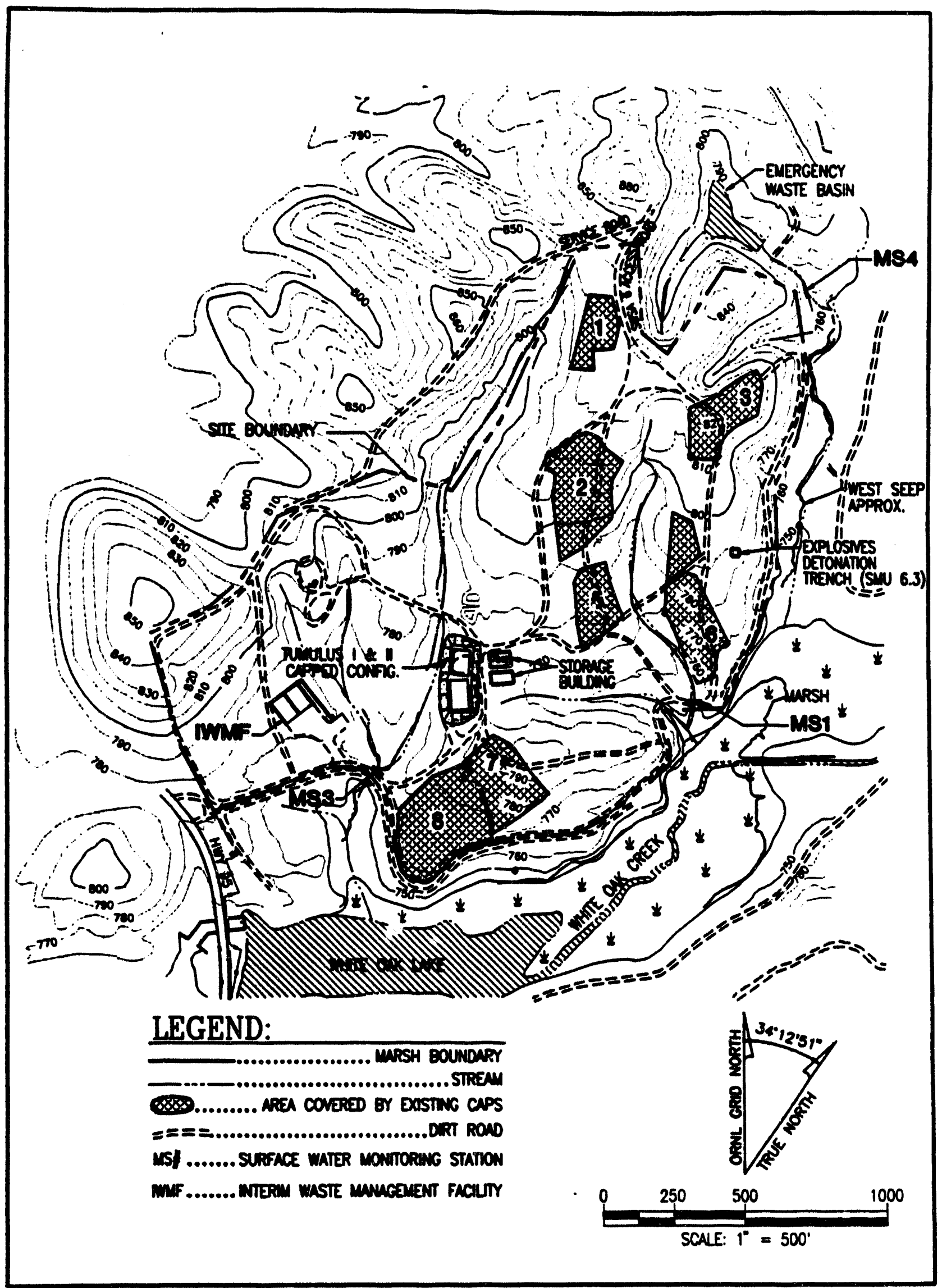

G: (93053\ECE_8_93\PLW2

Fig. 1.3. WAG 6 site map. 
appropriate procedures were in place to prevent additional RCRA-regulated waste from being disposed of at SWSA 6, it was reopened.

SWSA 6 areas that received RCRA-regulated hazardous and/or mixed wastes after November 8, 1980, are classified as RCRA-regulated units. A RCRA closure plan was submitted to TDEC in August 1988 and approved that September. The plan required that the units stop receiving RCRA wastes by November 1988. Also included in the original closure plan was a description of the series of activities leading to final closure, including an RFI.

Because disposal areas containing only LLW or mixed wastes are interspersed among the RCRAregulated units, closure of only the RCRA-regulated units would be difficult. Therefore, as proposed in the closure flan, Interim Corrective Measures (ICM) caps were placed over the RCRA-regulated wastes and run-on/runoff controls were installed to allow time for a single, comprehensive plan to be developed for closure and corrective action for all SWSA 6 disposal areas. The EWB, the EDT, and SWSA 6 were combined to form WAG 6 so that a comprehensive plan for all three contaminated sites could be developed.

In December 1989, the ORR, including ORNL, was placed on the National Priorities List (NPL) of CERCLA sites. Inclusion on the NPL required that WAG 6 remediation comply with CERCLA regulatory requirements. As required by the National Contingency Plan (NCP) as amended by the Superfund Amendments and Reauthorization Act (SARA), federal facilities on the NPL must enter into a Federal Facilities Agreement (FFA) with the EPA and the appropriate state government agency. Accordingly, DOE signed an FFA with EPA and TDEC for the ORR; the FFA became effective January 1, 1992. As a result of the FFA, WAG 6 is regulated under CERCLA as the main regulatory requirement, with RCRA as an applicable and/or relevant and appropriate requirement (ARAR).

Although the original closure plan mandated closure of the RCRA-regulated portions of SWSA 6 by October 1993, EPA recognized that this schedule was not feasible and requested a revised schedule for

- WAG 6. In response, DOE submitted a revised closure schedule on August 28, 1991, to TDEC under which the selected WAG 6 source control action was proposed to be completed in 1997. Because the CERCLA process has determined that source control action at WAG 6 will be deferred, RCRA closure will be delayed until the time that CERCLA identifies the best alternative for addressing the risk issues at the WAG. The current project schedule anticipates DOE and EPA will sign a Letter of Agreement by fall 1993, with monitoring continuing through 1998 .

\subsubsection{Overview of the RFI}

A key component of the RCRA strategy at WAG 6 was to complete an RFI by September 1991. The primary objectives of the RFI were to evaluate the site's potential human health and environmental impacts and to develop a preliminary list of alternatives to mitigate these impacts.

The WAG 6 RFI evaluated ORNL's existing waste disposal records and sampling data and performed the additional sampling and analysis necessary to describe the nature and extent of contamination; characterize key contaminant transport pathways; and assess potential risks to human health and the

- environment by developing and evaluating potential receptor scenarios. Estimated excess lifetime cancer 
risks as a result of exposure to radionuclides and chemicals were quantified for each potential human receptor. Potential impacts were qualitatively assessed for environmental receptors.

\subsubsection{Site hydrogeology}

An important aspect of the RFI was the information gathered to support a better understanding of the conceptual hydrologic model that describes water flow and water balance at the site. This conceptual model is the basis for many aspects of the proposed EMP. The conceptual hydrologic model for the ORR developed by Moore (1988) and revised by Solomon at al. (1992) and Moore and Toran (1992) also provides input for the WAG 6 conceptual model. According to the ORR conceptual model, the groundwater flow system at WAG 6 consists of four hydrologic zones: the storm flow zone, the vadose zone, the groundwater zone, and the aquiclude. The groundwater zone can be further subdivided into three intervals: the water table interval, the intermediate interval, and a deep interval. The combined groundwater-surface water flow concept is illustrated in Fig. 1.4.

The key aspects of the WAG 6 site hydrologic model are summarized below.

- The lateral near-surface component of subsurface water flow, primarily through large pores, accounts for most subsurface water flow off the WAG.

- Lateral groundwater flow in the water table interval (the zone surrounding the perennial water table) accounts for nearly all of the remaining subsurface water flow.

- Subsurface water discharges directly to surface water, or indirectly via seeps and springs.

- Nearly all water leaving WAG 6 is through the surface water drainages. This includes groundwater that resurfaces at seeps and springs.

- Contaminants from the on-WAG sources are transported off-WAG via the hydrologic flow pathways. Contaminant sources include wastes currently in the trench.

The conceptual hydrologic model is graphically depicted in Figs. 1.5-1.8. Figure 1.5 depicts the site geology. Three cross sections depicting actual site conditions with the conceptual groundwater flow model superimposed are presented as Figs. 1.6-1.8. Descriptions of the physical processes that are graphically depicted on these cross sections follow.

The storm flow zone extends from ground surface to a depth of about 3-7 ft. Nearly all subsurface water in undisturbed areas ( $-90 \%$ of water not consumed by evapotranspiration) flows through the storm flow zone via large pores. Lateral flow in the zone is caused by the large hydraulic conductivity through the pores. Subsurface water flowing in this zone is either quickly discharged to surface seeps and springs and surface water drainages, lost via evapotranspiration, or held as soil moisture. A small percentage of water flowing through the storm flow zone percolates through the vadose zone toward the water table interval. 


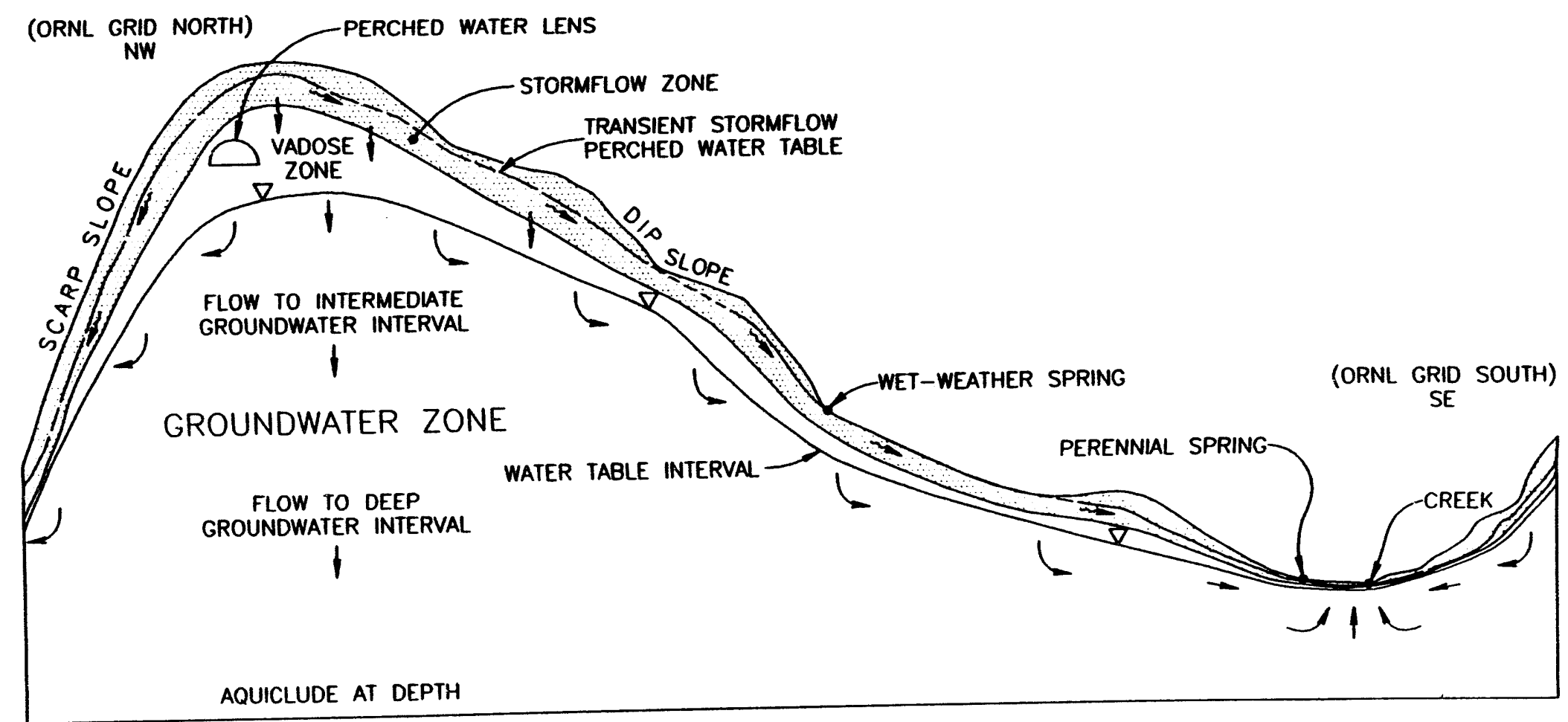

NOT TO SCALE

Fig. 1.4. Groundwater-surface water conceptual how system. 


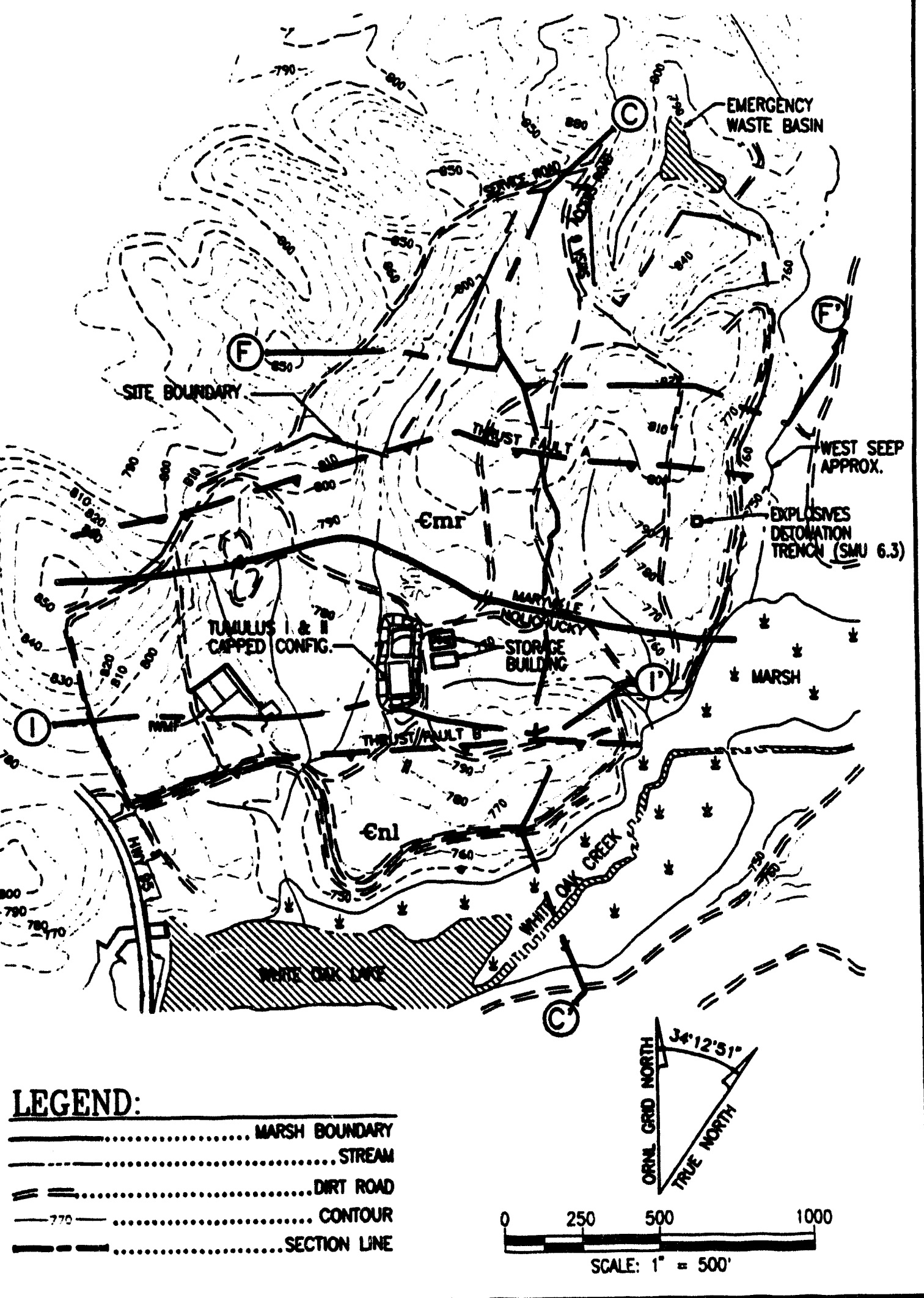

LEGEND:

Fig. 1.5. WAG 6 geology. 


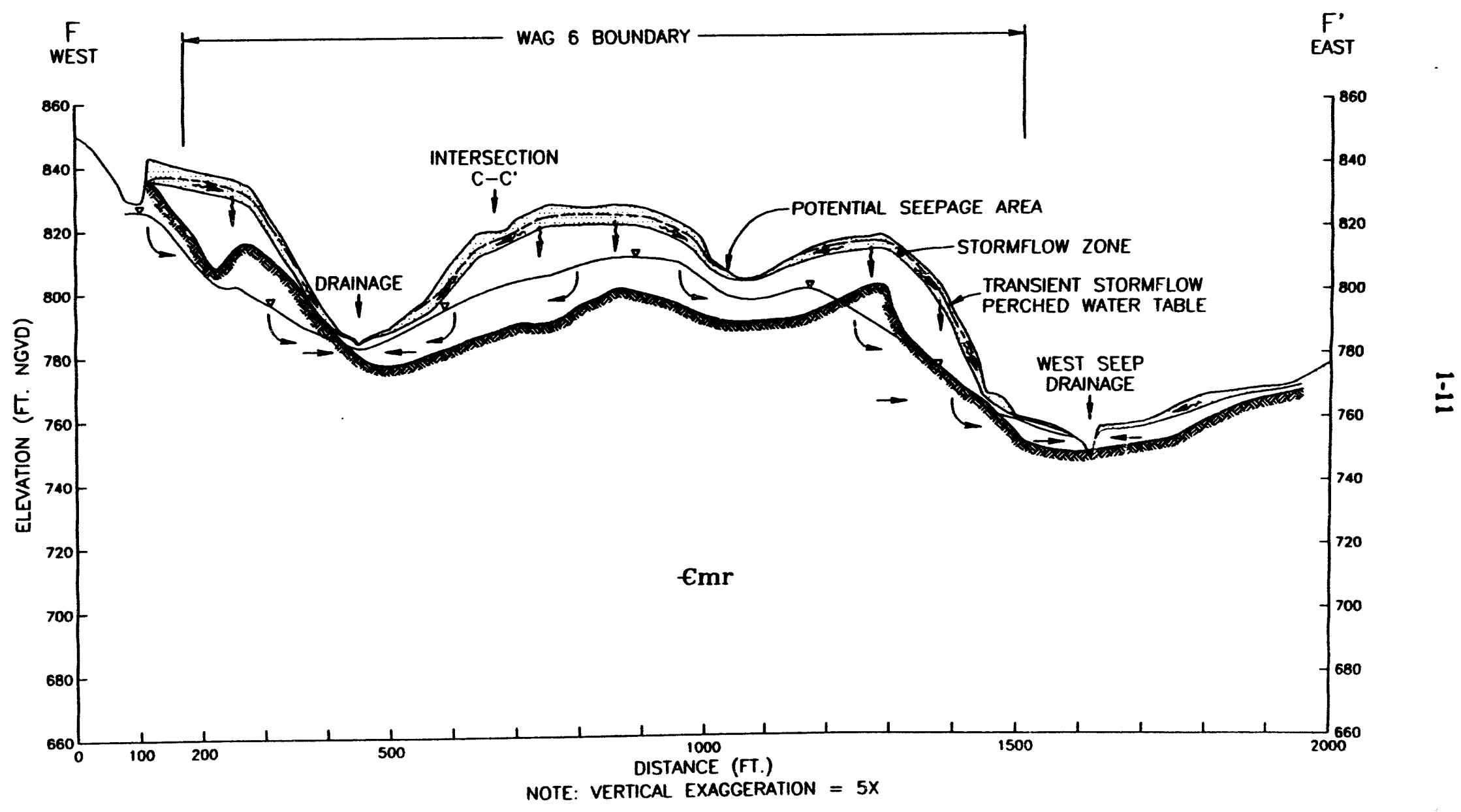

Fig. 1.6. Cross section F-F’. 


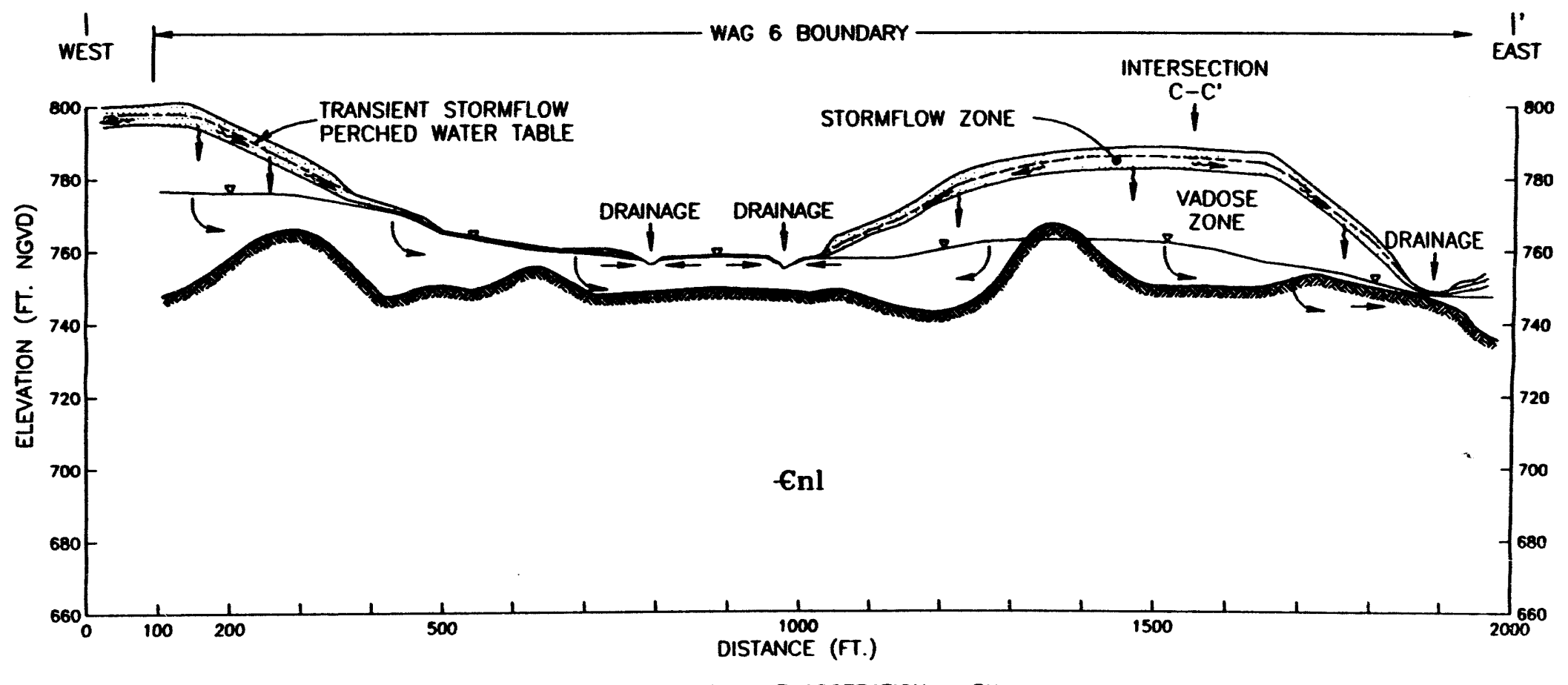

NOTE: VERTICAL EXAGGERATION $=5 X$

Fig. 1.7. Cross section I-I'. 


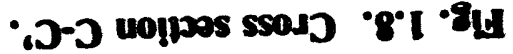

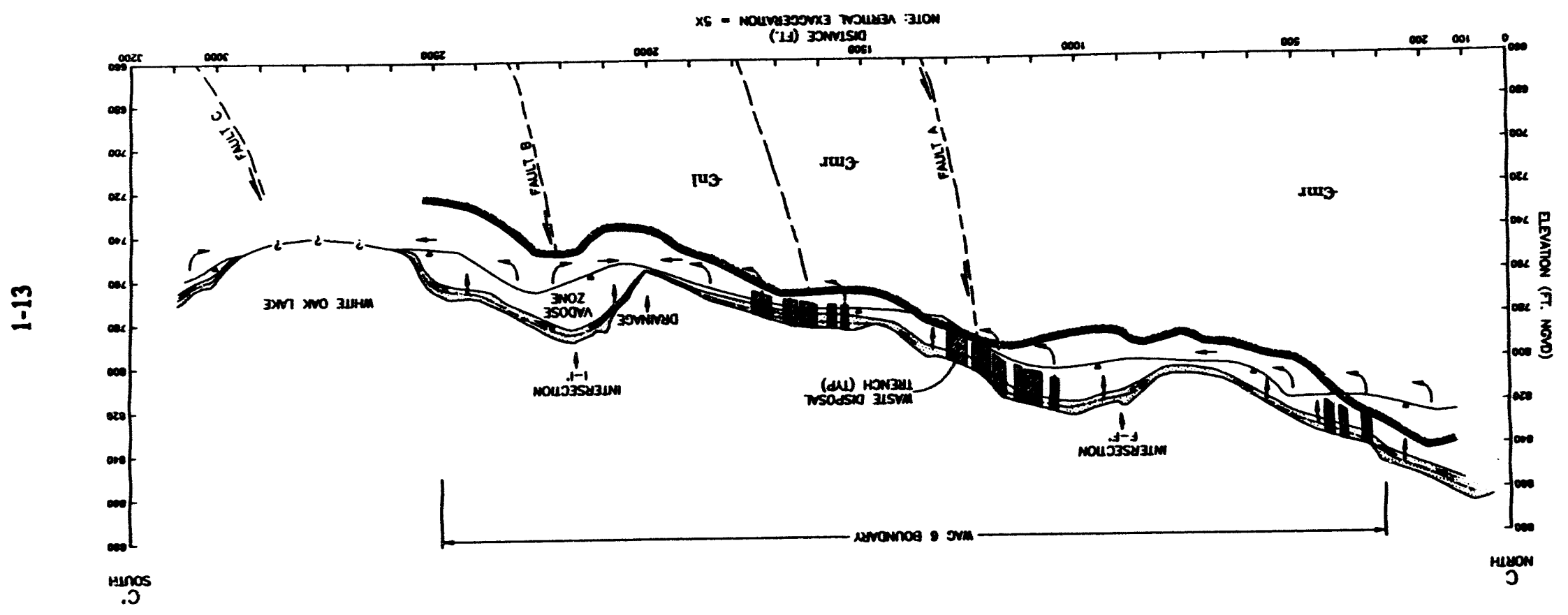


The vadose zone exists throughout WAG 6 except where the water table intersects the land surface. The vadose zone extends from the base of the storm flow zone to the top of the water table. Thus the thickness of the vadose zone is dependent upon seasonal and precipitation-induced water table fluctuations. The vadose zone is typically thicker under ridges than in the valleys. Recharge through the vadose zone is episodic (controlled by rainfall) and occurs through discrete permeable zones.

The water table interval is continuously saturated and transmits most of the water that reaches this depth to surface water. The bulk of the mass of water in the water table interval resides in the matrix porosity, however the majority of flow occurs in the fractures. Most water reaching the water table interval flows though fractures to seep and spring discharge points. Groundwater that is not transmitted along this interval to surface discharge points moves downward through a series of dipping, imbricate fracture zones toward the intermediate groundwater interval. The water table interval is characterized by calcium bicarbonate water chemistry.

The intermediate groundwater interval ranges from 100-330 $\mathrm{ft}$ in thickness and is characterized by a transition from mixed-cation bicarbonate waters to sodium bicarbonate waters. The change in groundwater chemistry from the water table interval has been attributed to ion exchange processes. Hydraulic conductivity within the intermediate interval is much lower than in the water table interval. Groundwater flow is slower than in the water table interval. As in the water table interval, the majority of the mass of water is contained in the matrix and the majority of flow occurs in fractures. Most groundwater in this interval flows very slowly to surface discharge points with a very small percentage flowing toward the deep groundwater zone.

The deep groundwater interval is characterized by very slow fracture flow with a significantly lower number of fractures (thus less transmissive) than the overlying intermediate groundwater interval. Waters within the deep interval typically contain greater concentrations of dissolved solids than the waters in the intermediate interval and are generally of the sodium bicarbonate type. The waters of the deep zone show increasing chloride content with depth as the aquiclude is approached. Flow in the deep groundwater interval is very small in relation to the shallow and water table intervals, therefore it is not depicted in the figures.

The aquiclude, occurring at 590-790 $\mathrm{ft}$ below ground surface, contains saline water. The water is chemically similar to sedimentary basin brines. The aquiclude is considered to be the lower boundary of groundwater flow on the ORR.

There are a few physical factors at WAG 6 that add additional complexity to the hydrologic system. It is believed that site reworking, in the form of road, cap, and building construction, has increased the surface runoff from precipitation in localized areas and reduced the potential for evapotranspiration. An additional factor is the interception of subsurface water flowing through the storm flow zone by waste burial trenches. Water can infiltrate into trenches forming perched water zones, and either percolate toward the water table interval or "spill" into the storm flow zone downgradient of the trench. The trenches and reworked soils change water flow paths over short distances, however this does not affect the overall hydrologic model for the site.

The ORR conceptual model can be used to address contaminant transport. The key aspects of contaminant transport at WAG 6 are summarized below (BNI 1991; Moore 1988; Moore and Toran 1992; and Solomon et al. 1992). 
- Nearly all contaminant transport occurs through the hydrologic system with the surface water system being the most important pathway for off-WAG transport.

- Subsurface water becomes contaminated by entering burial trenches and contacting buried wastes.

- Matrix diffusion is believed to play a major role in attenuating contaminant transport, and creating secondary contaminant sources down hydrologic gradient from waste burial areas.

Contaminant transport at WAG 6 occurs when water infiltrates into disposal trenches, leaches contaminants from buried wastes, then moves toward surface water discharge points via the storm flow zone or the water table interval, and during the erosion and transport of contaminated soils and sediments. Some disposal trenches reside within the water table interval and are subject to continual leaching. The transport of airborne-contaminated particulates is a potential transport mechanism only when contaminated soils are exposed.

In the subsurface pathway matrix diffusion is believed to act as an important attenuation factor to contaminant transport. Contaminants moving through the subsurface water system are taken into the rock/soil matrix via molecular diffusion. The rock/soil matrix can act as a secondary source of contaminants after primary sources are leached, removed, or isolated.

\subsubsection{Chemicals of concern}

During the RFI, a broad sweep of analyses (radiological, chemical, and geochemical) was performed on samples from all environmental media. Chemical analysis included all Appendix IX compounds. The RFI identified the COCs at WAG 6 as metals and volatile organic compounds (VOCs) that met the criteria spelled out in Risk Assessment Guidance for Superfund (EPA 1989). Man-made radionuclides are included in the $\mathrm{COC}$ list if detected levels exceeded the error level (counting and background error) - of the analysis. Several naturally occurring radionuclides were not included in the COC list because their concentrations have been found to be comparable to background concentrations (BNI 1991). Those species with single sampling event exceedances and sporadic detections were not included in the COC list. The COCs vary depending on the media, however, the major COCs released from the site are tritium (H), strontium-90 $\left.{ }^{50} \mathrm{Sr}\right)$, cesium-137 $\left({ }^{137} \mathrm{Cs}\right)$, cobalt-60 $\left({ }^{\circ} \mathrm{Co}\right)$, and VOCs. For the EMP, the large list of COCs identified in the RFI was decreased to inclucle only those compounds that have been detected above Maximum Contaminant Levels (MCLs). The COCs identified by the RFI are presented by medium in Table 1.1 . 
Table 1.1. COCs as identified by the RHI

\begin{tabular}{|c|c|}
\hline Media & Contaminant \\
\hline Groundwater, seeps, and springs & 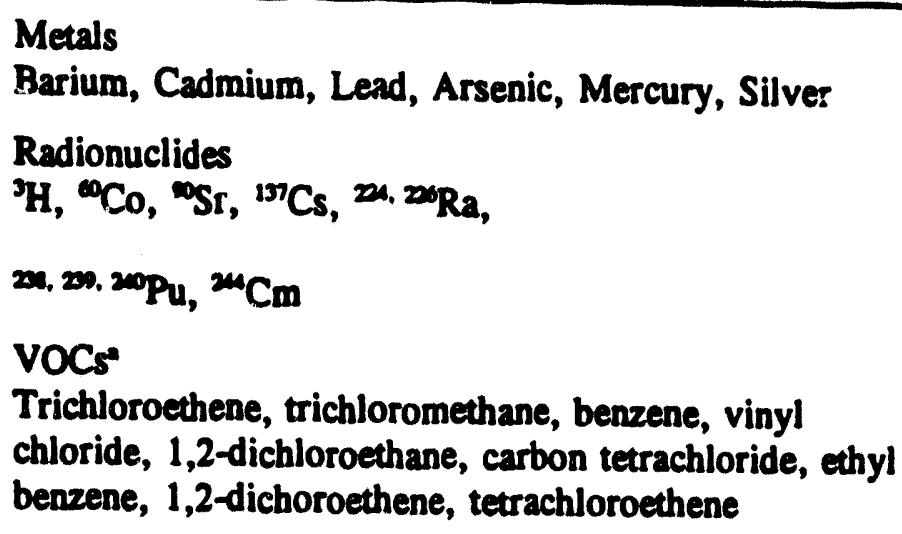 \\
\hline Surface water & $\begin{array}{l}\text { Radionuclides } \\
{ }^{3} \mathrm{H},{ }^{\infty} \mathrm{Co},{ }^{\infty 0} \mathrm{Sr},{ }^{137} \mathrm{Cs},{ }^{20,}{ }^{200} \mathrm{Pu},{ }^{222},{ }^{2 m} \mathrm{Cm} \\
\text { vOCs" } \\
\text { Trichloroethene, 1,2-dichloroethene, tetrachloroethene, } \\
\text { vinyl chloride }\end{array}$ \\
\hline Bedload stream sediments & $\begin{array}{l}\text { Radionuclides } \\
{ }^{3} \mathrm{H},{ }^{\infty} \mathrm{Co},{ }^{10 \mathrm{Sr}},{ }^{17} \mathrm{Cs}\end{array}$ \\
\hline
\end{tabular}

- VOCs and heavy metals are identified as a COC if the levels detected in the RFI meet or exceed a Safe Drinking Water Act (SDWA) MCL or healuh-based criteria in the case of sediments.

\subsubsection{Risk assessment}

Baseline Human Health Evaluation. As part of the RFI, a baseline risk assessment was performed to assess potential impacts contaminants at WAG 6 could have on human health and the environment if no remedial actions were taken. The baseline risk assessment included a human health evaluation and an environmental evaluation.

The methodology for the human health evaluation involved selecting potential COCs, identifying receptor scenarios and associated exposure pathways, estimating representative contaminant concentrations at receptor locations, collecting toxicity information, and estimating risks for each receptor.

Excess lifetime cancer risk is the probability that an individual will develop cancer as a result of exposure to the carcinogen(s) being evaluated. Excess lifetime cancer risk was quantified for radionuclides and carcinogenic COCs. For convenience, this probability is typically presented in exponential notation. For example, a risk of 0.000002 (or 2 chances in 1,000,000) is represented as $2 \times 10^{6}$. For chemical toxicants, a hazard index (HI) was estimated. The HI is the ratio of the estimated intake over the acceptable intake. If the ratio is $>1$, there may be a concern for public health effects. 
Two hypothetical land use scenarios were assumed for WAG 6-a no action scenario (which assumed a loss of access controls) and an institutional control scenario.

No action scenario. The no action scenario assumed that DOE's current access restrictions for the site become ineffective immediately. Site fencing, warning signs, patrols, and institutional controls are - assumed to disappear. This scenario is highly unlikely. However, evaluation of a no action scenario provides a baseline for decision-making and is required under Sect. $300.430(e)(6)$ of the NCP.

For the WAG 6 no action scenario, risks were evaluated for a hypothetical receptor who homesteads on-WAG over the next 30 years. Risks for the homesteader were evaluated for contaminant concentrations representing an average for the entire site and concentrations representing an average for the high-activity auger hole area. This 2-acre high-activity area contains $>85 \%$ of the WAG's radioactivity and represented an upperbound for exposure to radionuclides.

The estimated radionuclide and chemical risks for the hypothetical on-WAG adult homestead receptor evaluated using average concentrations were 1 (unity) and $3 \times 10^{4}$, respectively. Because these risks exceed the upper limit of EPA's target risk range, the need for continued DOE control of the site was demonstrated.

Ninety-nine percent of the radiological risk was associated with external exposure, with the majority of the dose resulting from isotopes of europium associated with the reactor control plates disposed in the high activity auger hole area. Although the computed radionuclide risks and doses were high, they were almost exclusively the result of worst case assumptions regarding the homesteader excavating deep into the wastes and spreading the waste across the ground surface. If the homesteader at the high activity auger hole area did not exhume wastes, estimated radionuclide risk would be orders of magnitude less $\left(9 \times 10^{3}\right)$.

The majority of the chemical risk was due to ingestion of groundwater and inhalation of water vapor - while showering. Vinyl chloride, carbon tetrachloride, and trichloroethene were the predominant contributors to the groundwater risk.

The HI for noncarcinogenic effects exceeded 1 for the on-WAG homesteader. The target organ of greatest concern was the liver. These results support the demonstrated need for continued DOE control of the site.

Institutional control scenario. The institutional control scenario assumed that DOE would continue to use WAG 6 as an LLW disposal site for the next 10 years and that this operational period would be followed by a 100 -year institutional control period. This scenario corresponds to DOE's operational and institutional control plans for WAG 6 for the next 110 years with the exception that, for assessment purposes only, the scenario assumed that DOE would not perform site closure or remediation other than to maintain the existing soil cover and vegetation over the disposal units.

For the institutional control scenario, risks were evaluated for hypothetical receptors for two different periods. For the next 30-year period (1990-2020), four receptors were evaluated-one an occupational- risk receptor (an ORNL employee) and the remaining three public-risk receptors (a hunter, a boundary receptor, and an off-WAG homesteader resident downstream along the Clinch River.) 
For the period corresponding to the release of institutional controls and other access restrictions in the year 2100, an on-WAG homesteader was evaluated. It was assumed this receptor could be exposed via a variety of pathways.

The estimated radionuclide risk for the hypothetical maintenance worker receptor was $10^{3}$. This risk was almost exclusively attributable to an external radiation dose of 2 rem accumulated over 30 years. Alhough risk to the employee exceeded the upper limit of EPA's target risk range, dose to the employee was well below the $5 \mathrm{rem} /$ year recommended in federal guidance for maximum occupational exposure. The estimate is conservative due to the assumption that the worker spends 8 hours a day for 30 years working directly over SWSA 6 waste disposal areas.

The eatimated radionuclide risk for the off-WAG homesteader along the Clinch River was $6 \times 10^{5}$. This risk was primarily a result of external exposure from decay of ${ }^{\circ} \mathrm{Co}$ and ${ }^{27} \mathrm{Cs}$ that were assumed to accumulate in soils as a result of crop irrigation over a period of decades. The risk contribution from assumed ingestion of surface water was $3 \times 10^{6}$. Because heavy irrigation is highly unlikely given the abundant rainfall in the region, and because a homesteader is more likely to use groundwater as a drinking water source rather than untreated surface water, this scenario is very conservative.

The estimated radionuclide risk for the future on-WAG receptor evaluated for site average concentrations was $3 \times 10^{-1}$. As described for the no action scenario homesteader, the majority of the risk was associated with external exposure to radionuclides. Estimated chemical risks were the same as for the no action scenario homesteader due to the assumption of steady state conditions for chemicals. Because risks exceed EPA's target risk range, the need for remedial actions effective beyond the year 2100 has been demonstrated.

Baseline Environmental Evaluation. The baseline environmental evaluation was the second component of the baseline risk assessment. The purpose of the evaluation was to assess potential risks to the environment from selected contaminants at WAG 6.

Field surveys conducted to support this evaluation indicated the following: No rare plant species are present in SWSA 6 . SWSA 6 stream drainages contain essentially no wetland community development. No threatened or endangered bird or mammal species listed by the U.S. Fish and Wildlife Service (FWS) are present at WAG 6. SWSA 6 streams contain no invertebrate species listed as threatened or endangered by the state of Tennessee or the FWS. One of the streams lacks adequate habitat for fish; the other has habitat suitable for native minnows, but none were found during an electroshocking survey. During a survey of the EWB, five bass were collected.

To assess potential environmental impacts under a no action scenario, hypothetical target species were selected. For each species, impacts were qualitatively addressed to the extent feasible given the available data. The target species selected were the tulip poplar, representing terrestrial flora; the whitetailed deer, red-tailed hawk, and raccoon, representing terrestrial fauna; bluegills and fathead minnows, representing aquatic vertebrates; and benthic macroinvertebrates representing aquatic invertebrates.

Potential impacts - terrestrial nora. The evaluation indicated that terrestrial flora (tulip poplar tree) would uptake contaminants, in particular "Sr. The combined high levels of ${ }^{*} \mathrm{Sr}$ in groundwater, surface water, and soils may cause toxic effects on vegetation growing in areas of these concentrations. WAG 6 soils may be marginally phytotoxic due to cadmium, and chromium may accumulate in the roots of vegetation but should not cause effects in plant foliage.

93-072P1090993 
Potential impacts - terrestrial fauna. Deer can ingest ${ }^{0} \mathrm{Sr}$ from contaminated vegetation, as was evidenced at SWSA 5, where contaminant levels in honeysuckle and blackberry were sufficiently high - tha ${ }^{10} \mathrm{Sr}$ levels in the bone of a $45-\mathrm{kg}$ deer could easily exceed the confiscation limit of $30 \mathrm{pCi} / \mathrm{g}$ if the deer browsed on such contaminated vegetation for a period of 1 week to 1 year (Garten and Lomax 1987). As part of the Biological Monitoring and Abatement Program, Loar et al. (1988) found that all

- field-collected mammals from SWSA 4 and the WOC floodplain had detectable levels of ${ }^{\circ} \mathrm{Sr}$ in bone tissue. Because of the large inventory of "Sr at WAG 6, species from the lower tropic levels such as voles, shrews, and rabbits may suffer adverse effects themselves, bioconcentrate ${ }^{\circ} \mathrm{S}$ in their bone tissue, and subsequently cause adverse effects in the red-tailed hawk and raccoon that prey upon them.

Cadmium levels in surface water have exceeded the suggested standard from the FWS. This metal is known to bioconcentrate in liver and kidney tissues of shrews by factors ranging from 15 to 33 times the levels found in the soil. Not only can cadmium adversely affect the soft tissue of shrews, but also those of the red-tailed hawks that prey upon them. The greatest potential for adverse effects to raccoons is through ingestion of contaminated surface water by the raccoons themselves and by voles upon which they prey and from ingestion of contaminated aquatic organisms. Although cadmium is taken up by plamts when the soils are acidic, ingestion of vegetation is not expected to be a major source of contamination to the deer. Incidental ingestion of soil may provide an additional pathway.

Potential impacts - aquatic environment. Although no fish were collected from streams in WAG 6 during surveys in 1990, one drainage provides adequate habitat for native minnows and could, therefore, support fish populations that could potentially be impacted by contaminants from WAG 6 under a no action scenario. Cadmium and copper exceed both the acute and chronic ambient water quality criteria for protection of aquatic organisms.

There are currently efforts ongoing by ORNL-ER to identify better methods for assessing potential ecological effects for source WAGs. Part of this effort will identify ways to link results of ecological asseasments of source WAGs to the larger scale watershed investigations. 


\section{MONITORING OBJECTIVES}

\subsection{PROGRAM OBJECTTVES}

A major objective of the ER Program at ORNL is to identify potential risks to human health and the environment presented by contaminants leaving the ORR via the WOC watershed. As stated in Sect. 1.2, contaminants from multiple sources are released via the WOC watershed and it is the objective of the ER Program to address the most problematic sources first. Presently, WAG 6 is not a high priority site because it contributes a small percentage of the off-site releases. However, as resources are shifted from WAG 6 to other sources, it is imperative to continue to monitor the changing role WAG 6 plays in contributing to off-site releases, and to understand if and when priorities should shift back to WAG 6.

To address the ER programmatic objectives, it was determined that the monitoring at the site should be able to detect a ten-fold change in risk at WOD that is attributable to contaminant releases from WAG 6. A ten-fold increase would result in WAG 6 flux contributions at WOD equal to $\sim 20 \%$ of the current total releases. It was also determined that an annual two-fold increase in total flux could alert decisionmakers to the increased relative contribution from WAG 6 early before the WAG becomes a higher priority for source control.

\section{EMP OBJECTIVES}

Three primary objectives (POs) have been identified for performing environmental monitoring at WAG 6. The three POs have been divided into sub-objectives for further clarification. The objectives - are listed in Table 2.1.

Table 2.1. Objective for WAG 6 EMP

Primary

objective

identifier
Objective description

Identify changes in risk associated with WAG 6

Estimate risk at boundary of waste unit and relative risk at WOD

Verify primary COCs that contribute to risk

Refine risk estimates

Meet regulatory requirements

Meet RCRA reporting requirements

Meet NPDES reporting requirements

Address DOE Orders 5400.1, 5400.5, and 5820.2A

Support implementation of interim or final actions

Identify major sources of off-WAG contaminant migration

Develop technologies to support site characterization and remediation activities 
PU1 is to identify changes in risk at the site to determine if additional action (either site characterization or remediation) is necessary. Risk associated with the WAG, as directed under PO11, will be measured at two points: the boundary of the waste unit where releases enter a surface water body (a common compliance point in CERCLA and RCRA actions) and at WOD. The evaluation of relative risk a WOD supports the ORNL ER Program objective of identifying the greatest contributors to off-site risk. Baseline risk estimates at these two points will be established with data gathered during the baseline monitoring effort. Measurements and data evaluation performed in subsequent years will identify changes in the baseline estimates.

As part of tracking changes in risk, it will be necessary to determine if the correct contaminants are being measured. PO1-2 requires that the existing list of $\mathrm{COCs}$ be checked periodically by analyzing samples for an expanded list of contaminants.

The third component of $\mathrm{PO} 1$ is sampling that will allow risk estimation methods to be continually refined. Estimating relative risk at WOD requires that total contaminant flux from the site be understood. A conceptual site water balance model and a numerical groundwater model are required to estimate total contaminant flux. PO1-3 calls for samples that will help confirm the conceptual model and refine the groundwater model.

PO2 is to ensure that all regulatory requirements that apply to WAG 6 are addressed in the monitoring effort. Regulatory drivers identified at the site include a RCRA permit (PO2-1), an NPDES permit (PO2-2), DOE Order 5400, which requires DOE contractors to ensure public protection against undue risk from radiation (PO2-3), and DOE Order 5826.2A, which monitors LLW storage and disposal.

PO3 ensures that data are collected that will support implementation of an interim or final action at the WAG if such an action is deemed necessary. A primary component of this objective is to be able to understand the source of off-WAG contaminants. The majority of the monitoring efforts under PO1 will be focused on contamination leaving the WAG at the boundary of the waste unit. These efforts will identify if action is necessary, but will not provide the information necessary to identify the source of the problem. PO3-1 is designed to ensure that internal locations on the WAG near the trenches indicate changes in releases from the sources.

PO3-2 directs efforts toward developing technologies for future site characterization and remediation efforts at ORNL. This plan addresses less complex technologies. Larger scale technology demonstrations will be addressed by separate plans.

\subsection{DATA QUALITY OBJECTIVES}

One of the most important steps in assuring the quality and useability of environmental monitoring data is the development of data quality objectives (DQOs). DQOs are developed during project scoping and during development of monitoring plans to ensure that the data collected are sufficient and adequate for decision-making.

A major requirement for identifying DQOs is a conceptual site model that describes what is known about the current situation at a site. A conceptual site model was developed for the WAG 6 EMP (Fig. 2.1). In Fig. 2.1, the WAG is defined by four distinct flow path groups: surface water discharge 


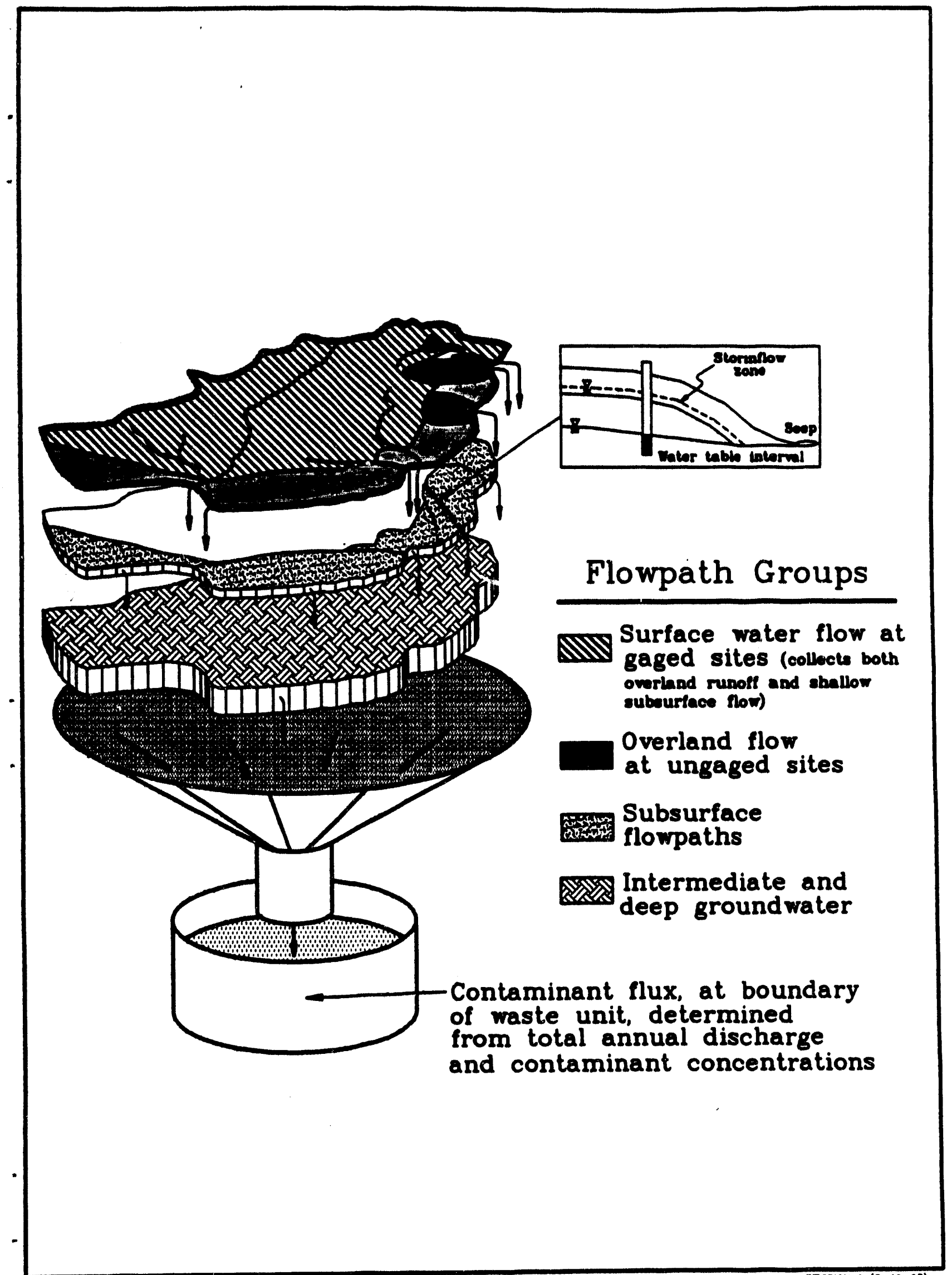

Fig. 2.1. Flow path groups. 
at gaged sites, overland runoff at ungaged sites, shallow subsurface water along the WAG perimeter, and intermediate to deep groundwater. Flow path groups are depicted in the figure on separate layers.

The gaged and ungaged surface water flow path groups are shown on the top layer in Fig. 2.1. Transport pathways on this layer consist of the main WAG 6 tributaries and two gullies located on the eastern perimeter. Currently, each of the four main tributaries on the southern perimeter of the WAG is gaged and will be monitored separately during the initial stage of the EMP. In 1994, the two eastern tributaries will be joined to form one monitoring location, MS1, and the two western tributaries will be joined to form one monitoring location, MS3. Overland flow in the two eastern perimeter gullies, shaded in Fig. 2.1, occurs only during storm events.

The shallow subsurface water discharge along the perimeter comprises the third flow path group, depicted by the middle layer in Fig. 2.1. Areal subsurface drainage (i.e., seeps and springs) along the southern and eastern perimeter of the WAG are the main transport pathways. While these areas are highly sloped toward the West Seep and WOL, they are not expected to have appreciable overland flow except in the two ungaged surface water gullies. However, shallow groundwater drainage and subsurface storm flow drainage are expected to flow to the receiving surface waters.

A set of assumptions that supports the conceptual model includes:

- Annual risk associated with the primary WAG 6 contaminants (e.g., ${ }^{3} \mathrm{H}$ and ${ }^{2} \mathrm{Sr}$ ) is directly proportional to annual contaminant flux (ACF) and thus can be estimated by measuring ACF. ACF is defined by:

ACF (mg/year) = water volume (L/year) * average contaminant concentration (mg/L).

- Water volume leaving the WAG 6 perimeter flows via four major flow path groups (Fig. 2.1 and Table 2.2).

- Flux via surface water at gaged sites can be measured with water volume and contaminant concentration samples taken by automatic samplers at the gaged monitoring stations MS1, MS3, and MS4. (These sites are shown in figures presented in Sect. 3.)

- Flux via the ungaged perimeter ("overland flow at ungaged perimeter sites" and "subsurface flow paths") can be estimated separately for five primary subsurface drainages (identified by surface topography) along the eastern and southern boundaries of the WAG (see Fig. 2.2).

- The flux via "overland flow at ungaged perimeter sites" and "subsurface flow paths" can be estimated using the WAG 6 water balance and groundwater model to calculate water volumes for each of the five drainages, and contaminant concentrations measured at the following locations:

- overland flow at ungaged sites (during storms) at B and C sampling locations along the eastern site boundary, and

- release via the subsurface flow path at five primary perimeter seeps and springs and/or shallow (water table interval) groundwater wells. 
Table 2.2. Water volume by now path

\begin{tabular}{lll}
\hline \multicolumn{1}{c}{ Flow path } & $\begin{array}{c}\text { Primary location(s) for } \\
\text { measuring flow }\end{array}$ & $\begin{array}{c}\text { Percent } \\
\text { contribution to } \\
\text { total flow from } \\
\text { WAG 6 }\end{array}$ \\
\hline Surface water at gaged sites & $\begin{array}{l}\text { gaged surface water } \\
\text { monitoring stations }\end{array}$ & $\approx 85 \%$ \\
$\begin{array}{l}\text { Overland flow at ungaged } \\
\text { perimeter sites }\end{array}$ & $\begin{array}{l}\text { Locations B \& C on } \\
\text { eastern boundary } \\
\text { subsurface flow paths (includes } \\
\text { interval groundwater) }\end{array}$ & $\begin{array}{l}\text { perimeter seeps and } \\
\text { springs and perimeter } \\
\text { shallow groundwater } \\
\text { wells } \\
\text { intermediate and deep }\end{array}$ \\
$\begin{array}{l}\text { Intermediate and deep } \\
\text { groundwater }\end{array}$ & $\begin{array}{l}\text { groundwater wells } \\
\text { (combined) }\end{array}$ & $<1 \%$ \\
\hline
\end{tabular}

- A single primary location for collecting a contaminant sample that represents each of the five subsurface flow paths can be identified during the baseline sampling effort.

- Flux from the intermediate and deep groundwater intervals will be estimated from contaminant concentrations at the perimeter groundwater wells (screened at intermediate depths) and results from WAG 6 water balance and groundwater models.

- The contaminants contributing the majority of the off-WAG risk are those that were consistently detected at elevated levels in the surface water during RFI sampling and estimated to be the greatest contributor to risk to a hypothetical receptor at WOD (see Appendix A). These contaminants are ${ }^{3} \mathrm{H}$ and ${ }^{\circ} \mathrm{Sr}$.

- Based on RFI sampling, a list of COCs for WAG 6 has been developed. Primary considerations in developing the list include comparison to background and MCLs. Most of these contaminants do not contribute significantly to elevated off-WAG risk (e.g., are not detected frequently at the gaged surface water stations). Most of the sampling effort will be directed towards the high-risk contributors $\left(\mathrm{H}\right.$ and ${ }^{\circ} \mathrm{Sr}$ ), however, the full list of RFI COCs will be analyzed less frequently yet ensure that ${ }^{3} \mathrm{H}$ and ${ }^{90} \mathrm{Sr}$ remain as the only high-risk contributors.

- To ensure that the RFI identified all important COCs, the Hazardous Substance List (HSL) Target Analyte List (TAL) and Target Compound List (TCL) will be checked during the baseline monitoring and once more during routine monitoring.

- Base flow grab samples taken at surface water gaged stations upstream of WAG 6 (WOC, West Seep Weir), at the perimeter of WAG 6 (MS1, MS3), and downstream of WAG 6 (at WOD) can provide information that will help validate contaminant flux estimates. 


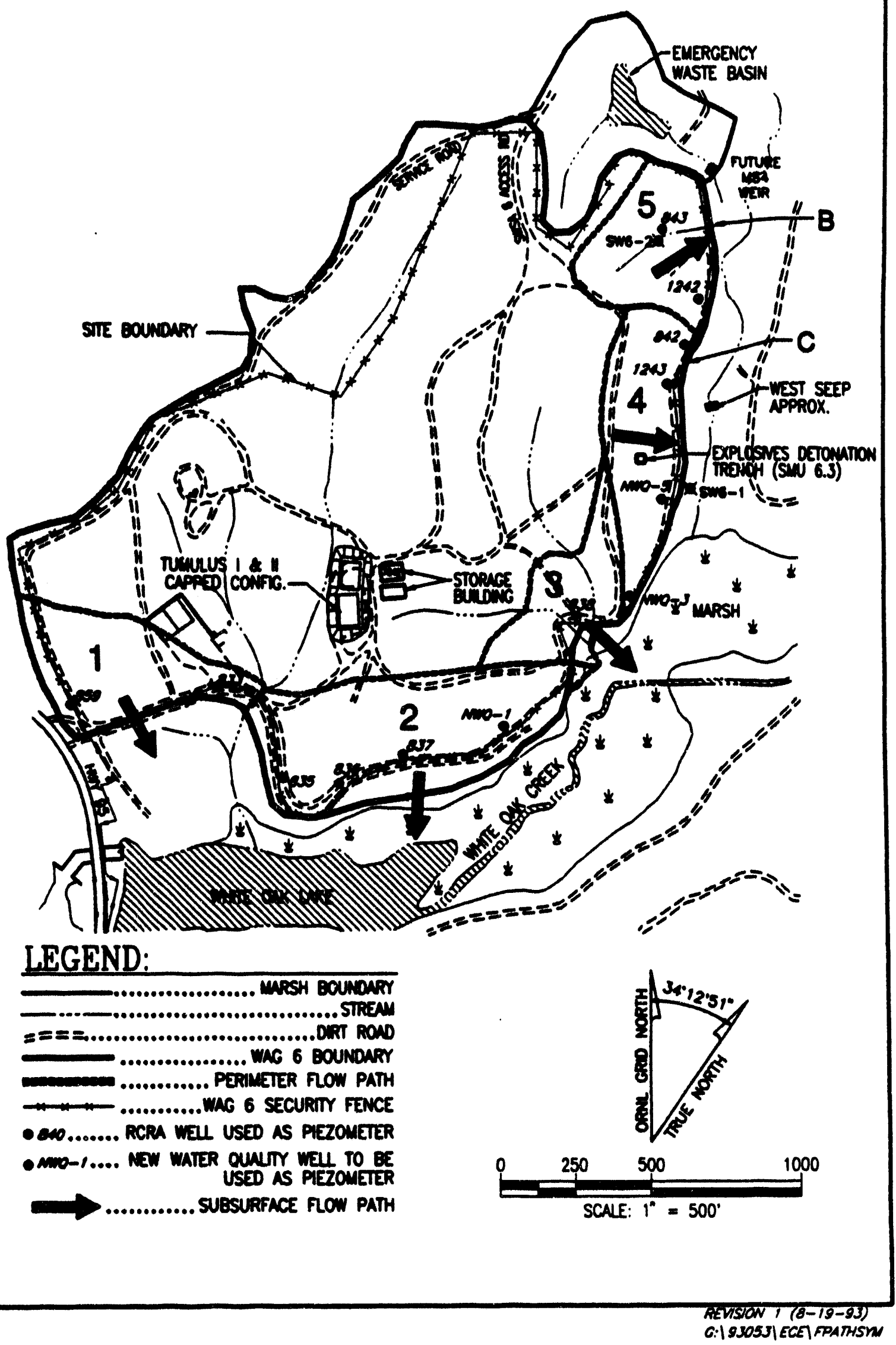

Fig. 2.2. Subsurface flow paths along ungaged WAG 6 perimeter. 
- The largest relative uncertainty in understanding the site is in the groundwater regime where, it is assumed, the smallest fluxes occur.

The DQO development process is based heavily on the site conceptual model and assumptions. The seven primary stages of the DQO development process defined by EPA (1992a) (Fig. 2.3) are:

- state the problem,

- identify decisions to be made,

- identify inputs to the decision (data uses and data needs),

- define the study boundaries,

- develop the decision rule (if/then),

- specify limits on uncertainty, and

- optimize design for obtaining data.

\subsubsection{Statement of the Problem}

The decision to defer remedial action at WAG 6 was based on information that suggests WAG 6 contributes relatively little $(<2 \%)$ to the total risk at WOD. Because of this, WAG 6 currently is a low priority site for source control remediation.

However, it has been determined that if WAG 6 (or any source WAG) were to contribute $~ 20 \%$ of the total risk at WOD, it could become a priority site for source control resources. For WAG 6 to contribute 20\%, a ten-fold increase in flux and risk from the site would have to occur. This increase could result from several potential scenarios including degradation of buried containers, reduced effectiveness of the ICM caps, or increased contact of the buried waste with infiltrating rainfall.

The priority of WAG 6 could also increase if the total risk at WOD decreased due to source control actions at other sources in the WOC watershed. For example, if source control action on WAG 5 results

- in decreased flux over WOD, the relative percentage of total flux associated with WAG 6 would automatically increase.

\subsubsection{Identify the Decisions to be Made}

To address the situation at WAG 6, the primary decision that must be made using the data collected during the environmental monitoring is:

Do changes in releases from WAG 6 change the priority of WAG 6 for source control remediation resources?

Decisions that support the primary decision include:

- Are contaminant releases from WAG 6 increasing?

- How much of an annual increase would trigger the need for expedited action?

- Are the proper COCs being measured?

- What type of remediation could be implemented if expedited actions were required? 


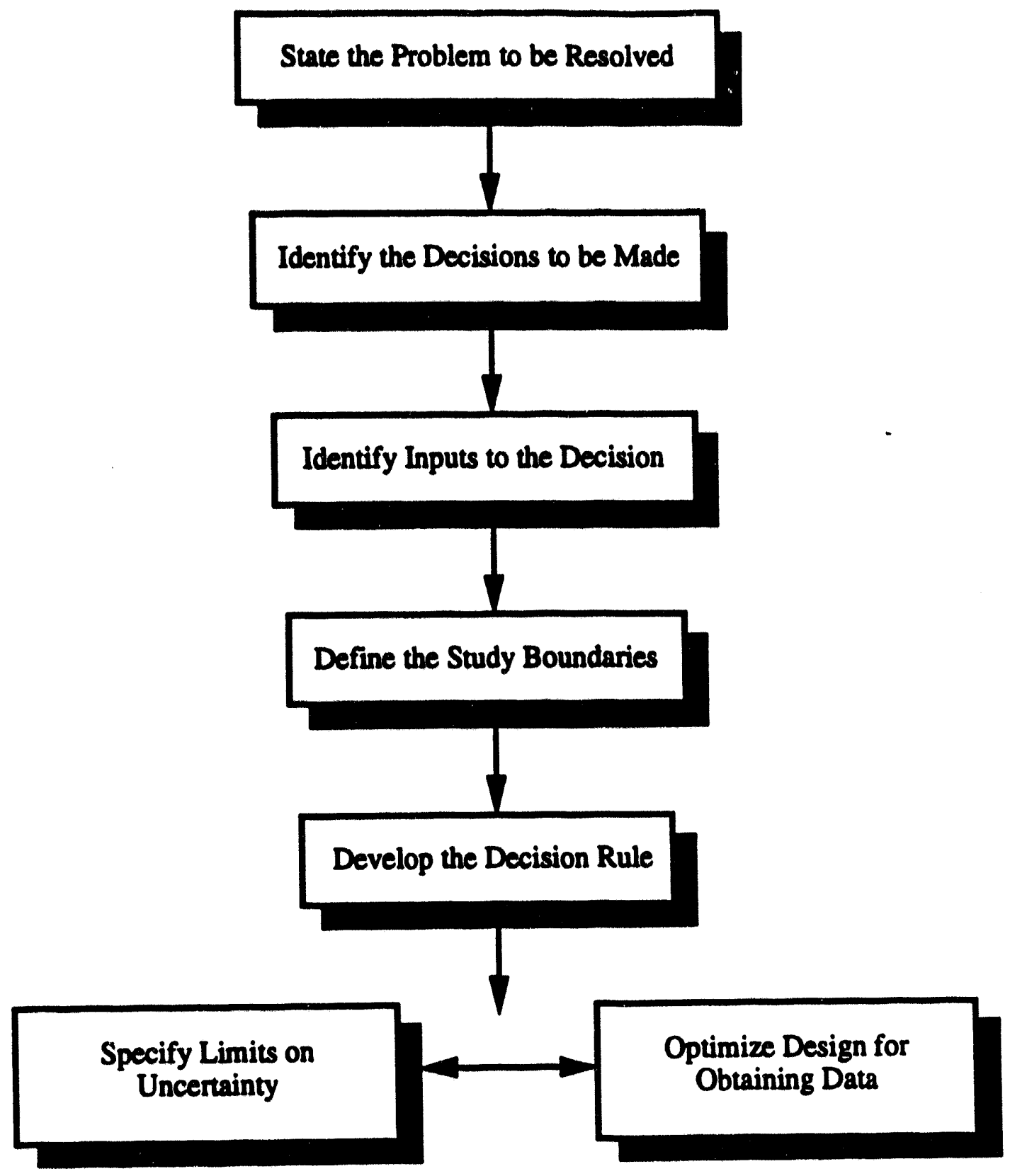

Fig. 2.3. WAG 6 DQO development process. 
- Which on-WAG sources would be most cost-effective to remediate?

\subsubsection{Identify Inputs to the Decision (Data Users and Data Uses)}

The data collected during the EMP will be examined primarily by the following data users to address the POs of the plan:

- WAG 6 project scientists, engineers and risk assessors

- to eatimate flux and risk changes at the boundary of the waste unit

- to extimate relative flux and risk at WOD attributable to WAG 6

- to confirm sito-related COCs

- to comply with regulatery requirements

- to confirm the site conceptual model and groundwater model

- to provide input into the regional groundwater model

- to evaluate potential remediation measures, if necessary

- Decision-makers (DOE, EPA Region IV and TDEC)

- $\quad$ ovaluate the need for continued access controls

- to determine the priority of WAG 6 for remediation resources

- to select source control measures if necessary

- to provide information for community relations.

Data uses and variables required to answer the primary questions are summarized in Table 2.3.

\subsubsection{Denne the Study Boundaries}

The apatial study boundary for the monitoring program is the geographical boundary of WAG 6, the drainage area of the EWB, and WOD. The plan focuses on the WAG 6 boundary that borders WOL to estimate flux released to the lake. The plan also addresses the groundwater within and beneath the WAG 6 trenches to track changes in releases from the sources.

The temporal boundary of the monitoring program is five 1-year periods, with annual reviews of the situation at the end of each year.

\subsubsection{Develop the Decision Rule}

The intent of the WAG 6 monitoring is to ensure that any changes in contaminant releases from the WAG are detected early enough such that a decision on remediation can be made prior to a significant increase in off-site releases. The decision rules that will be used to trigger the need for potential action include:

- If eatimated risk at the WAG 6 boundary continues to exceed the $10^{-4}$ to $10^{-6}$ risk range, then access controls must remain in place.

- If total contaminant flux increases by a factor of 10 total or a factor of 2 annually, then:

- aspects of the monitoring plan for the subsequent year may be altered to better understand the increase, and/or 
Table 2.3. Sunnmary of WAG monitoring data needs

\begin{tabular}{|c|c|c|c|}
\hline \multirow{2}{*}{$\begin{array}{l}\text { Objective } \\
\text { number }\end{array}$} & \multirow[b]{2}{*}{ Objective description } & \multicolumn{2}{|c|}{ Determine data neods to antisfy DQO requirements } \\
\hline & & Data uses & Data needs \\
\hline $\mathbf{P 0 1}$ & \multicolumn{3}{|c|}{ Identify changes in risk attributable to WAG 6} \\
\hline PO1-1 & $\begin{array}{l}\text { Extimate relative riak at } \\
\text { WOD }\end{array}$ & $\begin{array}{l}\text { Eetimnte risk at the boundary } \\
\text { of the waste unit and relative } \\
\text { sisk aseociated with WAG } 6 \\
\text { at WOD }\end{array}$ & $\begin{array}{l}\text { Concentrations of primary } \\
\text { COCs and water volume data } \\
\text { at gaged and ungaged perimeter } \\
\text { anmpling locations }\end{array}$ \\
\hline PO1-2 & $\begin{array}{l}\text { Verify COCs that } \\
\text { conaribute majority of risk }\end{array}$ & $\begin{array}{l}\text { Determine if the correct } \\
\text { contributors to rick are being } \\
\text { meamered in PO1-1 }\end{array}$ & $\begin{array}{l}\text { Periodic expanded andyre liat } \\
\text { to check for now sito-related } \\
\text { COC. }\end{array}$ \\
\hline PO1-3 & Refine risk extimates & $\begin{array}{l}\text { Refine groundwater model } \\
\text { used to ectimate water } \\
\text { volumes flowing scross } \\
\text { ungaged perimeter of site }\end{array}$ & $\begin{array}{l}\text { Water level measuremeats, } \\
\text { geochemical data, data from } \\
\text { upgradient and downgradient } \\
\text { sources, moteorological data }\end{array}$ \\
\hline $\mathbf{P O 2}$ & \multicolumn{3}{|c|}{ Meed regulatory requirements } \\
\hline PO2-1 & $\begin{array}{l}\text { Meet RCRA reporting } \\
\text { requirements }\end{array}$ & $\begin{array}{l}\text { Track and evalunie } \\
\text { concentrations of RCRA } \\
\text { parameters from RCRA wolls }\end{array}$ & $\begin{array}{l}\text { RCRA volatile and radiological } \\
\text { parnmeter concentrations from } \\
\text { RCRA wells }\end{array}$ \\
\hline $\mathrm{PO}-2$ & $\begin{array}{l}\text { Med NPDES reporting } \\
\text { requirements }\end{array}$ & $\begin{array}{l}\text { Report NPDES permit } \\
\text { discharge panmeters }\end{array}$ & $\begin{array}{l}\text { NPDES discharge points at the } \\
\text { site are aneociated with the } \\
\text { tumulus atructure and ICM } \\
\text { caps. Sepanate monitoring } \\
\text { activities will address NPDES } \\
\text { data }\end{array}$ \\
\hline PO2-3 & $\begin{array}{l}\text { Comply with DOE Order } \\
5400.5 \text { and } 5820.2 A\end{array}$ & $\begin{array}{l}\text { Track and evaluate } \\
\text { concentrations of site-related } \\
\text { radionuclides detected above } \\
\text { derived concentration guide } \\
\text { (DCG) levels }\end{array}$ & $\begin{array}{l}\text { Radiological scans (report } \\
{ }^{17} \mathrm{Cs},{ }^{\infty} \mathrm{Co} \text {, and Eu isotope } \\
\text { from gamma scan), }{ }^{3} \mathrm{H} \text { and }{ }^{10 S t}\end{array}$ \\
\hline PO3 & \multicolumn{3}{|c|}{ Support implementation of interim or final actions } \\
\hline PO3-1 & Identify major sources & $\begin{array}{l}\text { Track changes in groundwater } \\
\text { within or directly beeceath the } \\
\text { sources to identify major } \\
\text { sources in the eveat that } \\
\text { source control remediation is } \\
\text { required }\end{array}$ & $\begin{array}{l}\text { Groundwater quality data from } \\
\text { sampling location, including } \\
\text { interior wells, seeps and } \\
\text { springs, and Freach drains }\end{array}$ \\
\hline PO3-2 & $\begin{array}{l}\text { Develop technologies to } \\
\text { aupport site } \\
\text { charncterization and } \\
\text { remediation }\end{array}$ & $\begin{array}{l}\text { Develop methods to better } \\
\text { address the site } \\
\text { charncterization and } \\
\text { remediation needs at ORNL }\end{array}$ & To be determined \\
\hline
\end{tabular}




\section{2-11}

- $\quad$ source control measures may be implemented.

- If new COCs are detected and meet project-specific criteria for inclusion on the COC list, then they will be included on the list of site-specific COCs and analyzed routinely.

\subsubsection{Spedify Limits on Uncertainty}

Two primary types of uncertainty can be associated with the conclusions drawn from the data collected: (1) the uncertainty associated with the ability to detect and quantify the level of a contaminant in the environment (e.g., sampling and analytical uncertainty), and (2) statistical variations inherent in using sample data to represent a population, usually resulting from weather conditions and sample size issues. The WAG 6 EMP calls for multiple types of samples from various environmental media. Each sample type must address the first type of uncertainty in approximately the same manner. However, depending on the flow path and COC being evaluated, different factors contribute to environmental variability. The following two sections discuss these data uncertainty issues.

\subsubsection{Uncertainty associated with analytical variability}

Environmental data collection inherently involves some error, therefore some degree of uncertainty will exist in any decision based on environmental data. Conventional uncertainty constraints will be used to establish quantitative limits on total study error and corresponding measurement and sampling error measurement (EPA 1992a).

Any data derived from the sampling proposed in this monitoring plan will be collected and documented in such a manner as to be technically and legally defensible. Sampling will be performed - according to a set of approved procedures (as summarized in Sect. 3 and detailed in the Sampling and Analysis Plan) and, in general, laboratory procedures will be performed according to the EPA-Contract Laboratory Program (CLP) statement of work (SOW) protocols. It is suggested that all samples be analyzed at DQO Level III with an appropriate level of quality assurance. Ten percent of the data packages will be validated to a Level IV validation level to help provide confidence in the quality of the Level III analytical packages. Appendix B provides recommended analytical methods and Precision, Accuracy, Representativeness, Completeness, and Comparability (PARCC) parameters. The PARCC parameters have been chosen to ensure that all data used for decision-making have a high degree of accuracy associated with them and can be used to assess risk associated with WAG 6. An analytical quality Level II may be used for samples taken to address the concentration-discharge (C-Q) relationship.

\subsubsection{Uncertainty associated with environment variability}

The primary basis for all specific uncertainty considerations is the decision rule that states a two-fold increase in annual flux from WAG 6 could result in some action being taken. The decision rule mainly applies to ${ }^{\mathrm{H}} \mathrm{H}$ and ${ }^{\circ \mathrm{S} r}$ samples because virtually all of these samples are used to estimate total flux from the WAG. However, in the design of the sampling plan, more emphasis has been placed on understanding the variability in concentrations at the gaged sampling station, because it is assumed that $\mathbf{8 5 \%}$ of water flowing from the site flows through the gaged stations. Samples taken from interior groundwater wells and interior seeps and springs are used to identify changes in source releases. For interior sampling locations, it has been determined that sampling should be able to identify a trend in mean concentrations at any sampling location for which historical data are available. 
To limit the uncertainty in the risk estimates, higher sampling frequencies are being recommended for ${ }^{3} \mathrm{H}$ and ${ }^{0 S}$ r at gaged surface water stations because these samples will reflect the majority of the flux and risk leaving the site. A baseline sampling program with higher sampling frequencies for all sample locations is being recommended to establish a baseline against which statistical changes can be identified.

\subsubsection{Optimize Design for Obtaining Data}

Figure 2.4 shows the strategy for tracking changes in risk at WAG 6 over the 5-year monitoring period. Figure 2.5 summarizes the sample requirements. Based on the conceptual model and the questions that need to be addressed by the program (e.g., is the risk associated with flux from WAG 6 increasing?), it was determined that optimal use of monitoring resources during routine monitoring results in the following:

- a relatively large number of samples at the gaged surface water stations, because $-85 \%$ of flow from the site can be measured at these stations;

- fewer samples along the ungaged perimeter, because flux from the two ungaged flow paths contribute $15 \%$ of the total flow;

- a focus on ${ }^{~} \mathrm{H}$ and ${ }^{\circ} \mathrm{Sr}$ as the major analytes, because they contribute nearly all the off-site risk from the WAG; and

- the required number of samples to meet regulatory requirements.

The baseline monitoring effort includes additional sample types to confirm the site conceptual model and groundwater model, an increased number of sample locations to identify the most representative locations for sampling the ungaged perimeter in the subsequent years, and increased sample frequencies to escablish the statistical baseline (e.g., the means and variances of contaminant concentrations and flow volumes against which year-to-year changes can be compared). Final determination of the optimal sample locations and frequencies for the routine annual monitoring may be changed based on the results of the baseline sampling. The baseline monitoring also includes samples to test the $C-Q$ hypothesis and potentially establish the C-Q relationship to the extent that it could be used in site characterization activities at ORNL. The C-Q relationship is described in detail in Appendix C.

The routine annual monitoring will provide enough routinely collected samples to determine if releases from the WAG are changing. During the 5th-year of routine annual monitoring, the RFI COC list will be reconfirmed by sampling for expanded analytes. 
-

Expanded

Analyte List for

COC Check

1.

C-Q Sampling

a
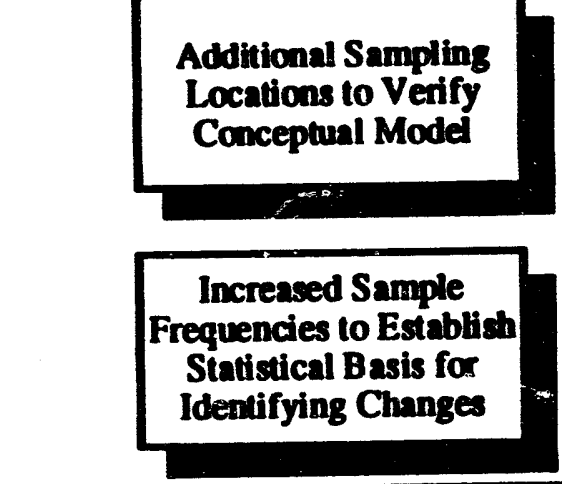

Expanded

Analyte List for COC Check

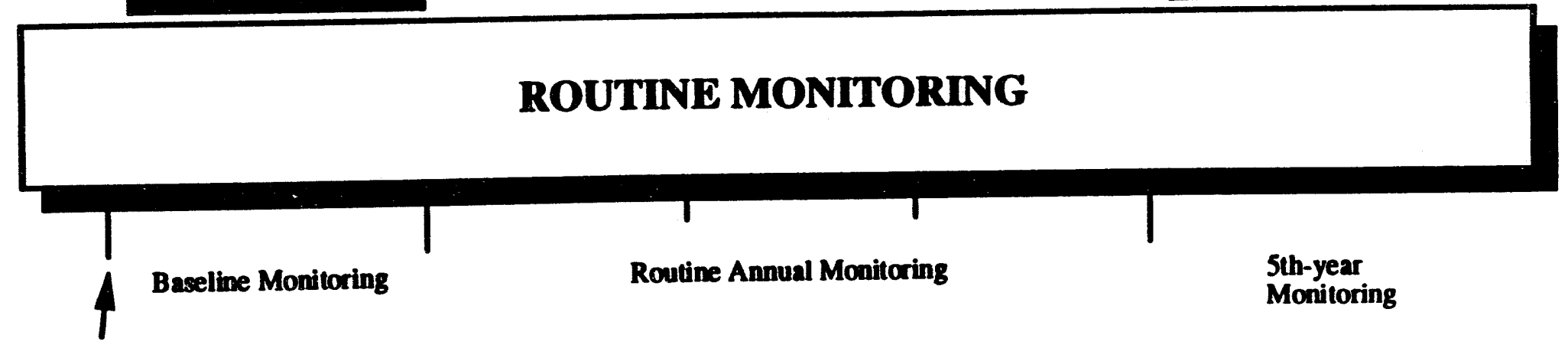

Point in time when new

gaged monitoring

stations are operational

Fig. 2.4. WAG 6 conceptual monitoring stratezy. 


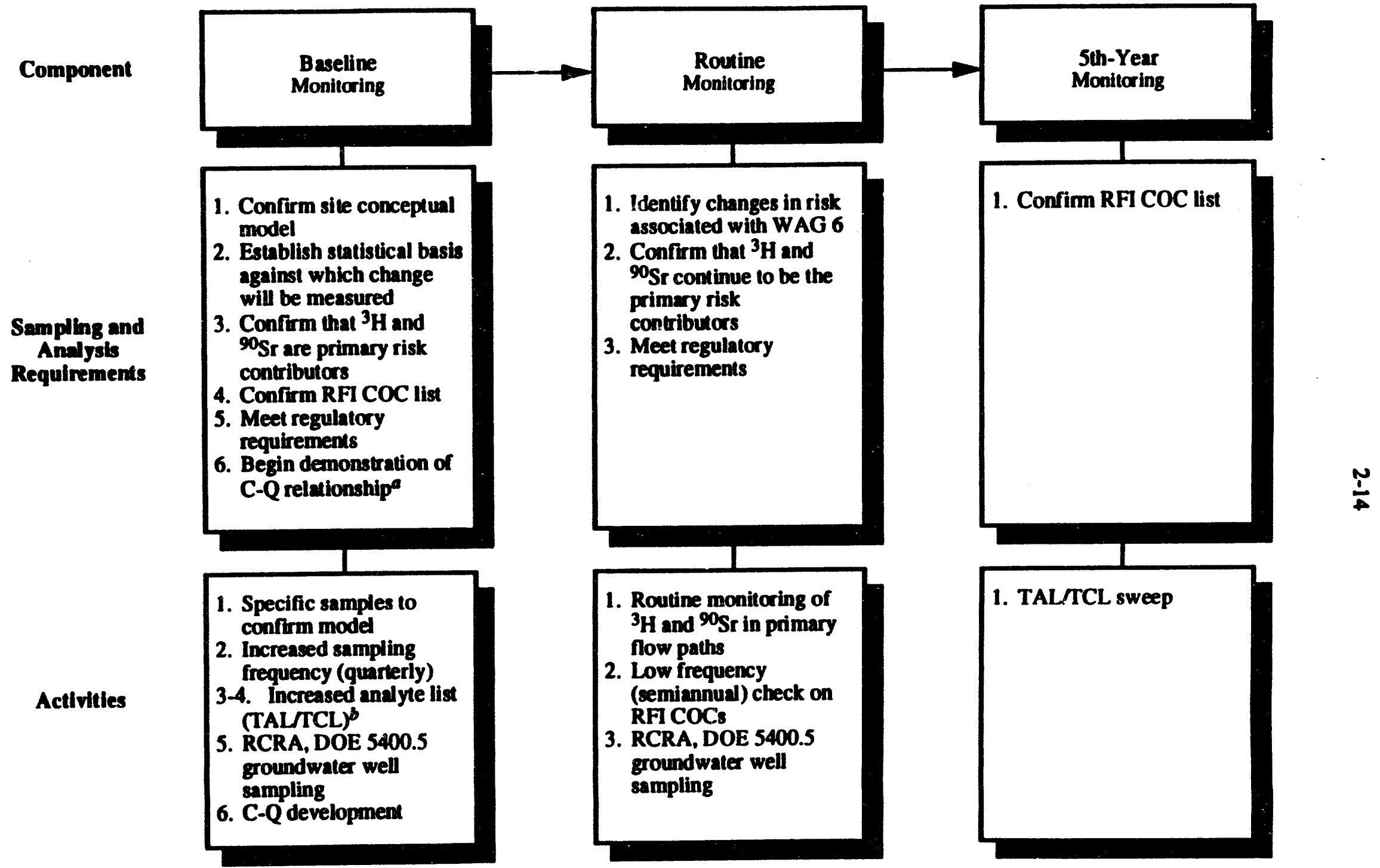

${ }^{a} \mathrm{C}-\mathrm{Q}=$ concentration va volumetric flow rave relationship (a site chanciterization technology demonatration)

bTAUTC = target analyte listharget compound list

Fig. 2.5. Summary of WAG 6 monitoring plan strategy. 


\section{ENVIRONMENTAL MONITORING TASKS}

This section presents an overview of the sampling and analysis activities proposed for WAG 6. Prior to presenting the plan, the section provides a framework for understanding the proposed monitoring, including an explanation of the major sampling tasks, sampling locations and methods, and the proposed list of analytes. After presenting the framework, a SAP is presented in summary form. Detailed SAPs that can be used to guide specific field activities are being prepared as stand-alone documents.

These include SAPs for:

- surface water monitoring,

- seeps and springs monitoring,

- groundwater quality monitoring,

- groundwater level monitoring, and

- meteorological monitoring.

The detailed SAPs expand on information presented below in Sects. 3.1 and 3.2. The detailed SAPs are written for use by field personnel and identify standard operating procedures required for all sampling activities and quality control requirements for all sampling and analysis tasks.

\subsection{SAMPLING AND ANALYSIS FRAMEWORK}

The following subsections present the WAG 6 framework within which sampling and analysis - activites will take place. The framework provides the basis for the SAP presented in Sect. 3.2.

\subsubsection{Monitoring Locations}

This section presents the monitoring locations for sampling activities during the WAG 6 EMP. Many of the locations discussed herein were established during the RFI and other past sampling activities. Other locations need to be relocated (in the case of gaged monitoring stations), some need to be identified (in the case of seeps and springs), and additional groundwater wells and piezometers need to be installed.

\subsubsection{Surface water}

The RFI (BNI 1991) identified seven main surface water drainages within WAG 6, all originating inside the WAG boundary. Each drainage and its associated watershed is shown in Fig. 3.1. Approximately $80 \%$ of the WAG 6 surface area drains directly to WOL through four major tributaries, which are identified in Fig. 3.1 by monitoring station and the drainage nomenclature retained from the RFI: MS1-DB, MS1-DA, MS3-FA, and MS3-FB. In general, these drainages can be characterized as short (i.e., <2000 ft) and well-defined. A fifth major drainage area is not as well-channelized as the previous four, but carries the drainage from another 7\% of the WAG 6 surface area. This tributary is located in the northeastern part of the WAG and drains into the EWB. The accumulated water contained in the EWB is periodically pumped over the dam. This discharge, or seepage through the dam, from the EWB enters a narrow stream that joins the West Seep Tributary (WST) and eventually drains into WOC - and WOL. 


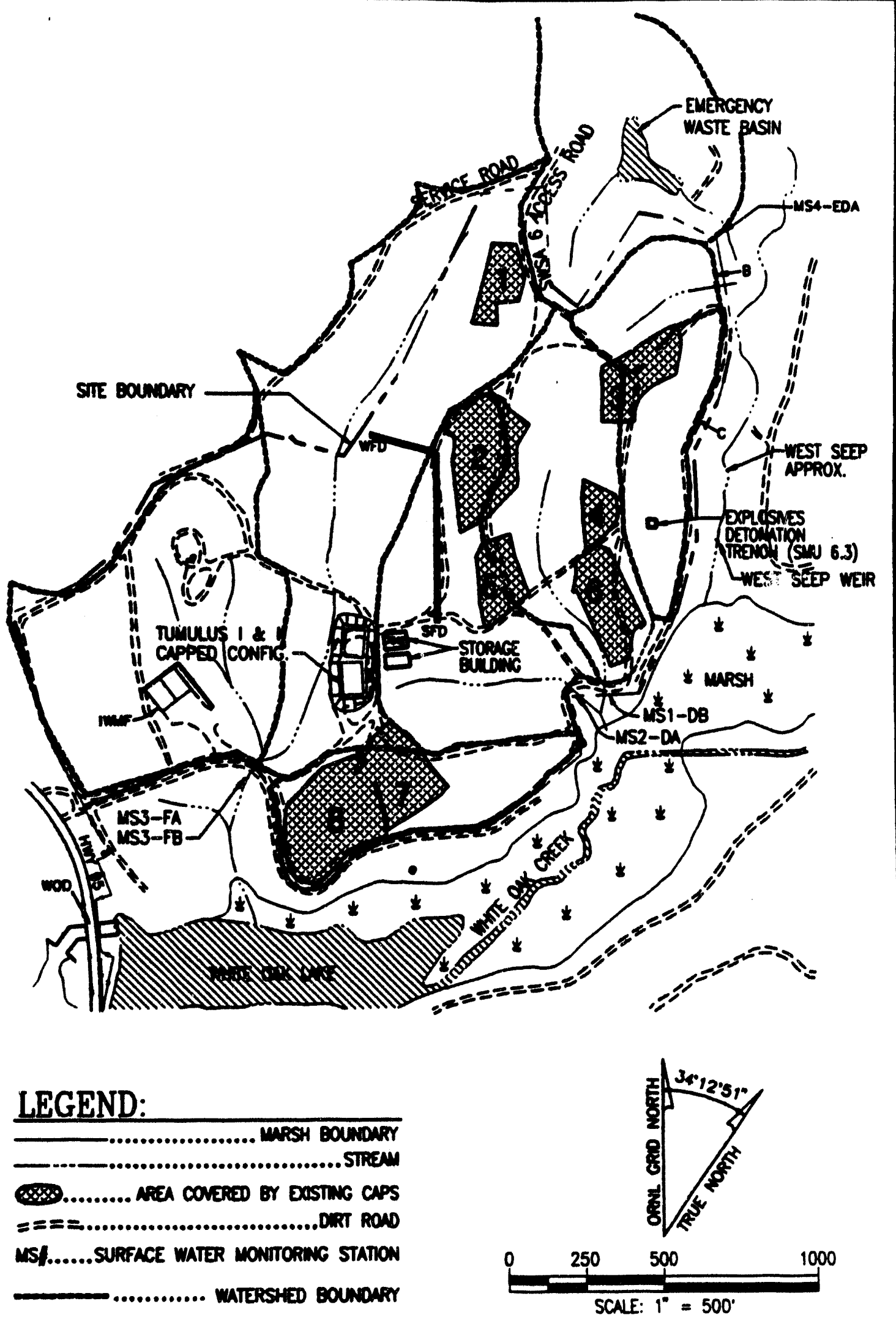

6:193053,ECE TS_PLA

Fig. 3.1. WAG 6 watersheds and surface water monitoring stations. 
Additional discharge in the MS3-FB and MS1-DA drainages is contributed by the 49 trench area French drain, also shown in Fig. 3.1. This subsurface structure was constructed in the central area of - the site to intercept groundwater from upgradient areas and lower the water table below the base elevation of the 49 trench area waste trenches.

The remaining two drainage areas, identified in Fig. 3.1 as B and C, are located in the eastern portion of the WAG. These areas are highly sloped and surface streams are short and not well-defined. Drainage from B and C are carried to the WST. Areas B and C discharge only during storm events. Due to the lack of channelization, storm water runoff from both drainages $B$ and $C$ is comprised mainly of overland sheet flow or shallow concentrated flow.

Flow in the five main tributaries is predominantly intermittent. Flow during dry weather conditions (i.e., base flow) is mainly due to groundwater discharge from the water table. During dry periods, especially in the summer months, the water table will decrease to an elevation below the stream bed, drastically reducing or altogether eliminating base flow. Storm water runoff in the main tributaries is comprised of base flow, overland flow and subsurface storm flow. The relative amount of each component to storm water runoff has not been quantified. Increases in the amount of impervious area within the WAG through implementation of the ICM caps has affected the runoff for most drainages by increasing peak flows from 5 to 27\%. In general, runoff hydrographs for WAG 6 drainages during the summer months are of short duration (i.e., minutes to hours) and relatively low volume, peaking very quickly after the start of runoff and then returning at a slower pace to near base flow conditions. In contrast, winter storm hydrographs are lengthy (i.e., hours to days), with broader peaks. Runoff peaks are extended by the long, slow increases and decreases in runoff, characteristic of the greater duration, and precipitation volume, of winter storms. In addition to increased precipitation volume, nearly saturated surface and subsurface conditions in winter months increases the volume of subsurface storm - flow and corresponding runoff.

Surface Water Monitoring at Gaged Stations. It was determined that the quality and location of the existing gaged monitoring stations needed to be upgraded at the site prior to performing baseline sampling activities. Existing structures commonly become submerged during storm events, effectively reducing the discharge rate through the flume and causing the values to be in error. The planned upgrades will merge the DA and DB discharges (new MS1), and merge the FA and FB discharges (new MS3) into stations fully equipped to handle all expected ranges of flow. Gaged monitoring station MS4 will be established in the small tributary north of the WST to gather data on the discharge and contaminants that are released from the EWB area. The locations of the new stations were chosen to provide the most useful data for determining total off-WAG flux. The new gaged surface water monitoring stations will be equipped with hydraulic structures and electronic data logging and autosampling equipment. Table 3.1 presents the new gaged monitoring station locations, along with a description of the hydraulic structure installed at each site. Table 3.1 also presents additional gaged stations that will be used less frequently. These monitoring stations also are shown in Fig. 3.1. 
Table 3.1. Gaged surface water monitoring stations

\begin{tabular}{|c|c|c|}
\hline Stration & Locntion & Hydraulic structure \\
\hline MS1* & $\begin{array}{l}\text { just inside the SWSA } 6 \text { fence at the routed } \\
\text { confluence of drainage DA and DB, several yards } \\
\text { wouth of ICM cap } 6\end{array}$ & 4.5-ft $\mathrm{H}$ flume \\
\hline MS3* & $\begin{array}{l}\text { juat inside the SWSA } 6 \text { fence at the routed } \\
\text { confluence of drainage FA and FB, near ICM cap } 7\end{array}$ & 4.5-ft H flume \\
\hline MS4 & $\begin{array}{l}\text { in a narrow atroam that carries EWB drainage to the } \\
\text { WST, southeast of the EWB dam }\end{array}$ & 1.5-ft $H$ flume \\
\hline WOD & WOD, eouth of WAG 6 in WOL & \\
\hline
\end{tabular}

The physical dacription of the tation is based upon currently proposed design. Theac gaged sites include electronic data boging and avtosampling equipment.

Approximately $80 \%$ of the WAG 6 surface area discharges through the location where stations MS1 and MS3 will be located. Each of these stations will be located at the end of the most downstream reach of combined internal drainages, near the WAG perimeter, making them ideal for off-WAG contaminant release monitoring. Data gathered at MS4 station will account for discharge from another 7\% of WAG 6.

The West Seep Weir (WSW) station may also be used in the WAG 6 monitoring program to provide additional data for the characterization of the contaminants released from the northeast perimeter of the WAG. WSW is located on the WST, north of the WOL floodplain and south of the MS4 station. A large seep and spring area that is located just northwest of the station discharges contaminated groundwater from WAG 7 to the WST. Because WST receives inputs from WAG 6, WAG 7, and WAG 2 , interpretation of the radiologic data gathered at WSW will be confounded by the contaminant inputs from other WAGs. Identification of the source(s) of the contaminants identified in samples gathered at WSW will be possible as more data from WAG 2 and WAG 7 become available.

Surface Water Monitoring at Ungaged Locations. Several ungaged locations will be monitored as part of the surface water monitoring task. Table 3.2 and Fig. 3.1 present the ungaged locations. Ungaged locations include two interior perimeter drainages that discharge only during storm events and will be monitored to capture storm runoff along the ungaged perimeter. 
Table 3.2. Ungaged surface water monitoring locations

\begin{tabular}{l} 
Stration \\
\hline B Location \\
drainage area B, located on the eastern perimeter north of ICM cap 3 and south \\
of the EWB \\
drainage area C, located on the eastern perimeter south of drainage B and west of \\
ICM cap 4
\end{tabular}

Data gathered at drainages $B$ and $C$ will allow quantification of the contaminant release from the eastern perimeter of the WAG during storm events. Contaminant flux determination is less straightforward in these areas because there are no acceptable sites for flumes or weirs.

Several surface water locations will be sampled infrequently as part of an effort to perform mass balance confirmation on the base flow flux estimates for the WAG. Locations upgradient (at points in the WST and WOC) and downgradient (WOD) of WAG 6 will provide data to help confirm flux estimates. Two stations are in French drain outlets, WFD and SFD, and are included in the surface water monitoring task to monitor changes in contaminant releases closer to the sources. The contaminants released from the French drain originate from an areally integrated source, due to the configuration of . the drain across the WAG.

\subsubsection{Seeps and springs}

Seeps and springs represent the continuum between the surface water and groundwater systems. Seeps and springs are the points at which subsurface water discharges to the surface water system and thus mark the predominant groundwater discharge points. As with the ungaged surface water stations, monitoring perimeter seeps and springs will help quantify flux moving across the ungaged perimeter of the site. Internal seep and spring monitoring will help identify changes in releases from the sources.

Seeps and springs at WAG 6 tend to occur in low lying areas near drainages. Because characterization and/or location of seeps and springs at WAG 6 has not been conducted in detail sufficient to support the needs of the EMP, a seep and spring survey has been planned and will be conducted prior to baseline monitoring. Field reconnaissances will be conducted to identify visible seeps and springs throughout WAG 6 and adjacent to the eastern and southern boundaries where additional information will greatly aid the estimates of off-site contaminant flux. The initial reconnaissances will be conducted - during the dry season, concentrating on areas where groundwater discharge would be most probable (i.e., heads of drainages, along drainages, etc.). Any identified seeps and springs will be numbered and flagged. The identified locations will be revisited during wet weather conditions. Selection of a seep or - spring as a permanent monitoring point will be based on a combination of flow conditions, suspected contamination levels, and location. Seeps and springs located on the eastern and southern boundaries 
where off-site flux measurements will be difficult will have higher priority than those located in the inner drainage systems where flux can be monitored downgradient at the gaged monitoring stations.

\subsubsection{Groundwater}

Groundwater wells will be monitored for four primary purposes:

- perimeter wells will be monitored to help estimate flux leaving the ungaged perimeter via the subsurface flow path,

- selected interior wells will be monitored to track releases near the sources,

- all wells will be monitored for water level measurements to improve the calibration of the groundwater model to estimate flow across the ungaged perimeter, and

- RCRA compliance wells will be monitored to address RCRA permit requirements.

In general, existing groundwater wells at WAG 6 will be used to conduct water quality, water level, and RCRA compliance monitoring. The exception to this is six proposed wells along the southern and eastern perimeters of the site and nine internal non-trench piezometers.

Fizure 3.2 presents a water bble contour map developed from previous sampling efforts (wet season, February 1990). The general configuration of water table contours has been found to be essentially the same in both the wat and the dry season and from year to year. In general, upgradient areas lie to the northwest of WAG 6 and downgradient areas lie to the east and the southeast of the WAG. Because the site topography has considerable relief (Fig. 1.3), and the water table is a subdued replica of the ground surface, the water table contours are complex. The internal drainages are responsible for some of the complexity in the water table configuration because they act as discharge zones for groundwater. In essence, the internal drainages segregate areas of shallow groundwater at WAG 6, preventing uniform shallow groundwater flow and interaction across the entire WAG. Waste disposal areas generally lie on topographic highs or ridge crests between the internal drainages.

Well Loentions for Groundwater Quality Monitoring. The groundwater monitoring network is divided into three functional groups: upgradient perimeter wells, downgradient perimeter wells, and interior wells (Fig. 3.3 and Table 3.3). Upgradient wells have been characterized as uncontaminated and representative of background water quality. Downgradient wells have been categorized on the basis of location down hydraulic gradient or along geologic strike of waste disposal areas, and will be used to estimate the flux of groundwater contamination through the ungaged shallow perimeter and intermediate to deep groundwater system. Interior wells have been chosen to provide adequate spatial distribution for asseasing WAG-wide changes in releases from the waste sources. Interior wells have been chosen on the basis of historical data that indicate these wells are close to active sources and pathways. 


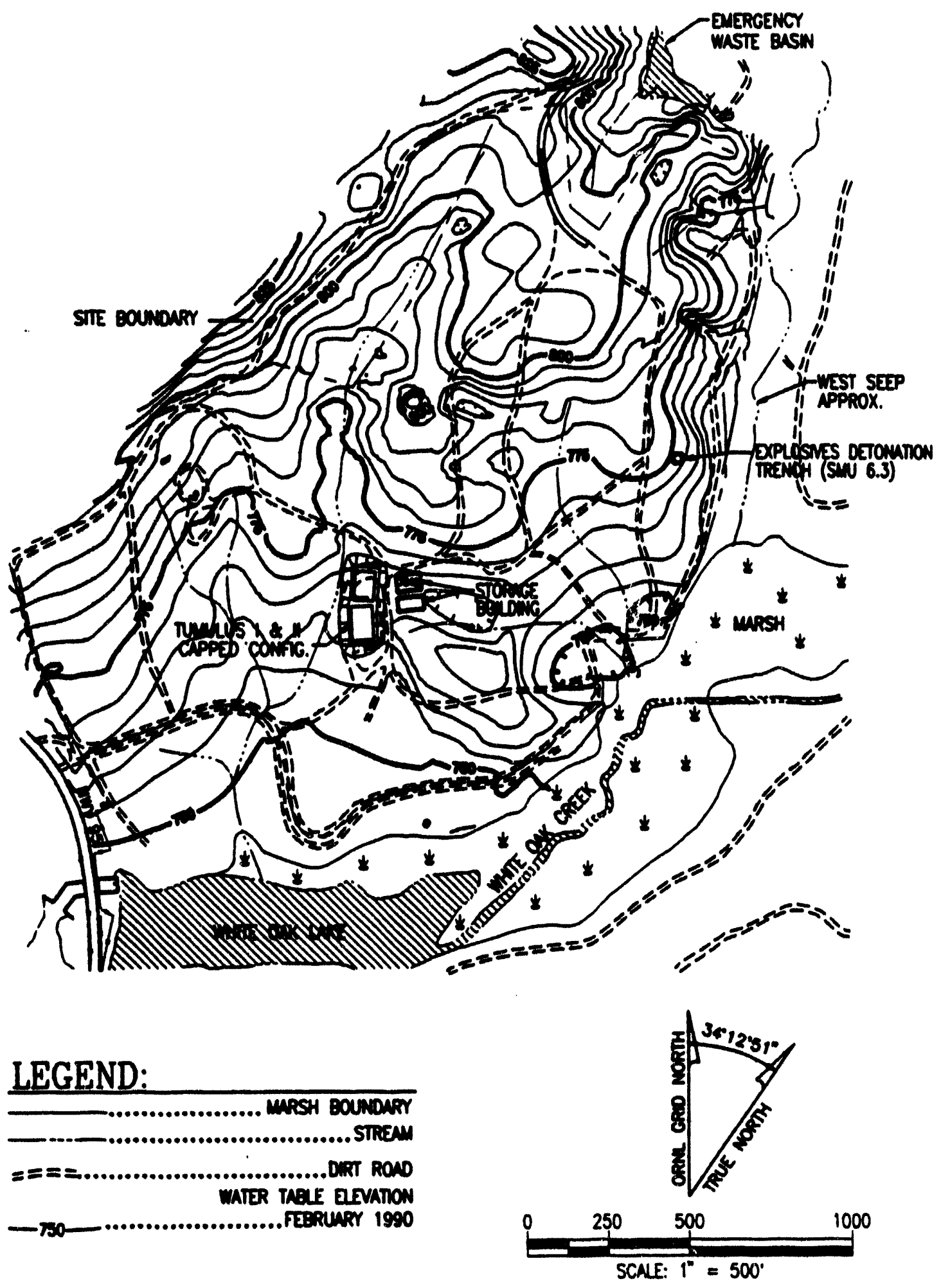

G.193053 ICE 8 9J WTCONT DWC

Fig. 3.2. Water table contour map for WAG 6. 


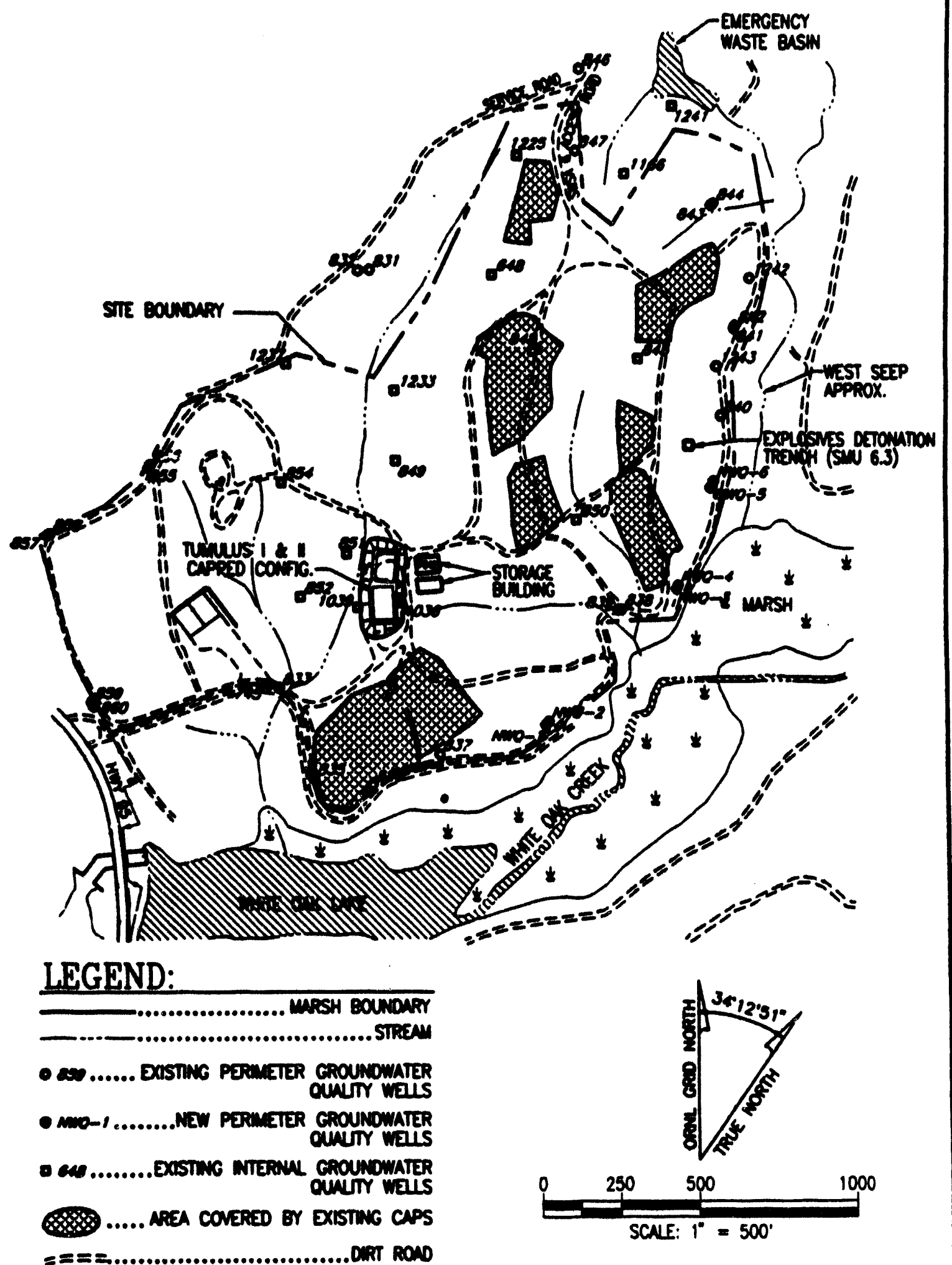

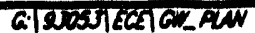

Fi. 3.3. Locations of groundwater quality monitoring wells. 
Table 3.3. Wells to be sampled for groundwater quality

\begin{tabular}{|c|c|}
\hline Well type & Well number \\
\hline Upgredient perimeter wells & $745,831,832,833,846,855,856,857,858,859,860$ \\
\hline Downgradient perimeter wells & $\begin{array}{l}835,836,837,838,839,840,841,842,843,844,847,1242 \\
1243 \text {, NWQ-1, NWQ-2, NWQ-3, NWQ-4, NWQ-5, NWQ-6 }\end{array}$ \\
\hline Internal wells & $\begin{array}{l}648,845,848,849,850,851,852,854,1036,1039,1166 \\
1225,1233,1237,1241,848\end{array}$ \\
\hline
\end{tabular}

Groundwater quality monitoring data gaps were identified along the eastern portion of WAG 6 in the RFI (BNI 1991). These data gaps will be rectified by the installation of groundwater monitoring wells along the eastern perimeter of WAG 6. All additional monitoring wells will be installed in such a manner as to conform to RCRA protocol (EPA 1986). The locations and proposed depths of installation for these additional wells are presented in Table 3.4.

Table 3.4. Approximate locations of the proposed groundwater quality monitoring wells

\begin{tabular}{ccccc}
\hline Well * & North & Enst & Elovation & Total Depth \\
\hline NWQ-1 & 15940 & 24690 & 759 & 30 \\
NWQ-2 & 15950 & 24700 & 759 & 60 \\
NWQ-3 & 16375 & 25110 & 762 & 25 \\
NWQ-4 & 16385 & 25115 & 762 & 55 \\
NWQ-5 & 16700 & 25220 & 758 & 25 \\
NWQ-6 & 16720 & 25230 & 758 & 55 \\
\hline
\end{tabular}

Table 3.5 provides detailed information on the perimeter groundwater wells that will be sampled for water quality. Table 3.6 provides similar information on the interior wells.

Well and Pieameter Locations for Water Level Monitoring. All groundwater monitoring wells and piezometers will have periodic water level measurements taken. A subset will be instrumented for continuous measurement of water levels and temperature and conductivity. This section presents the grouping and location of wells and piezometers to be used for water level monitoring efforts.

The water level monitoring network is divided into two groups: trench piezometers and non-trench monitoring wells and piezometers. Trench piezometers are located directly in disposal trenches, or in the backfill surrounding silos and auger holes, and are used to measure the water levels within these waste disposal units. Non-trench monitoring wells and piezometers are located outside of the trenches themselves, and are used to measure the elevation of the water table as well as lateral and vertical hydraulic gradients. 


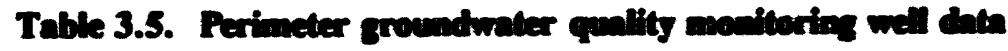

\begin{tabular}{|c|c|c|c|c|c|c|c|c|c|c|c|}
\hline \multirow{3}{*}{ Well : } & \multirow{2}{*}{\multicolumn{2}{|c|}{ ORNL grid location }} & \multirow{3}{*}{$\begin{array}{l}\text { Ground } \\
\text { olev. }\end{array}$} & \multirow{3}{*}{$\begin{array}{l}\text { Mees. } \\
\text { point }\end{array}$} & \multirow{3}{*}{ Total } & \multicolumn{4}{|c|}{ Soreen indervar } & \multirow{3}{*}{$\begin{array}{l}\text { Moniloring } \\
\text { inderval zomose }\end{array}$} & \multirow{3}{*}{ Una/Clase } \\
\hline & & & & & & \multicolumn{2}{|c|}{ Depoth } & \multicolumn{2}{|c|}{ Flewtion } & & \\
\hline & North & Enet & & & & T/SCR & B/SCR & T/SCR & B/SCR & & \\
\hline 831 & 17387.4 & 24133.5 & 835.6 & 839.6 & 50.7 & 24.2 & 50.4 & 811.4 & 785.2 & Stallow Bodrock & RCRA-WQMW \\
\hline 832 & 17385.6 & 24096.7 & 838.3 & 841.6 & 85.9 & 58.1 & 85.6 & 780.2 & 752.7 & Shallow Bedrock & RCRA-WQMW \\
\hline 846 & 18030.7 & 24803.5 & 861.0 & 865.0 & 81.0 & 55.0 & 81.0 & 806.0 & 780.0 & Sthellow Bedrock & RCRA-WQMW \\
\hline 855 & 16755.3 & 23427.7 & 811.3 & 815.2 & 52.0 & 30.0 & 51.7 & 781.3 & 759.6 & Shallow Bedrock & RCRA-WQMW \\
\hline 856 & 16764.4 & 23432.9 & 810.2 & 813.7 & 82.0 & 55.0 & 81.2 & 755.2 & 729.0 & Deep Bedrock & RCRA-WQMW \\
\hline 857 & 16538.0 & 23106.3 & 847.2 & 849.6 & 70.0 & 49.7 & 69.6 & 797.5 & 777.6 & Regolith & RCRA-WQMW \\
\hline 858 & 16542.1 & 23115.8 & 847.2 & 850.7 & 106.4 & 84.5 & 106.1 & 762.7 & 741.1 & Shallow Bedrock & RCRA-WQMW \\
\hline 745 & 16067.8 & 23808.3 & 754.2 & 757.0 & 60.2 & 35.0 & 60.2 & 719.2 & 694.0 & Shallow Bedrock & RCRA-WQMW \\
\hline 833 & 16056.9 & 23842.4 & 752.7 & 756.3 & 31.0 & 9.5 & 30.7 & 743.2 & 722.0 & Shallow Bedrock & RCRA-WQMW \\
\hline 835 & 15767.7 & 23951.8 & 759.9 & 762.9 & 27.5 & 5.5 & 26.9 & 754.4 & 733.0 & Rezolith & RCRA-WQMW \\
\hline 836 & 15748.2 & 24138.8 & 763.3 & 767.3 & 28.5 & 7.0 & 28.2 & 756.3 & 735.1 & Resolith & RCRA-WQMW \\
\hline 837 & 15845.6 & 24352.6 & 771.1 & 774.5 & 31.6 & 10.0 & 31.3 & 761.1 & 739.8 & Regolith & RCRA-WQMW \\
\hline 838 & 16308.7 & 24934.8 & 752.3 & 755.1 & 22.8 & 5.0 & 21.5 & 747.3 & 730.8 & Regolith/Bodrock & RCRA-WQMW \\
\hline 839 & 16308.8 & 24923.6 & 751.6 & 755.2 & 56.0 & 25.0 & 56.0 & 726.6 & 695.6 & Shallow Bedrock & RCRA-WQMW \\
\hline 840 & 16928.6 & 25251.7 & 766.9 & 770.9 & 26.9 & 11.0 & 26.6 & 755.9 & 740.3 & Stullow Bodrock & RCRA-WQMW \\
\hline 841 & 17206.3 & 25294.8 & 766.0 & 769.7 & 56.5 & 36.3 & 56.3 & 729.7 & 709.7 & Shallow Bodrock & RCRA-WQMW \\
\hline 842 & 17216.1 & 25298.4 & 767.3 & 770.1 & 26.8 & 8.0 & 23.2 & 759.3 & 744.1 & Shallow Bodrock & RCRA-WQMW \\
\hline 843 & 17597.1 & 25221.4 & 781.4 & 783.9 & 21.0 & 3.6 & 19.3 & 777.8 & 762.1 & Regolith/Bedrock & RCRA-WQMW \\
\hline 844 & 17602.5 & 25228.6 & 781.0 & 784.8 & 52.0 & 24.6 & 51.7 & 756.4 & 729.3 & Shallow Bedrock & RCRA-WQMW \\
\hline 847 & 17769.9 & 24790.5 & 839.6 & 843.1 & 67.0 & 45.4 & 65.8 & 794.2 & 773.8 & Shallow Bedrock & RCRA-WQMW \\
\hline 859 & 16009.4 & 23246.2 & 777.9 & 781.0 & 26.5 & 5.4 & 26.2 & 772.5 & 751.7 & Rezolith & RCRA-WQMW \\
\hline 860 & 15996.6 & 23252.9 & 777.1 & 780.2 & 61.8 & 34.0 & 61.5 & 743.1 & 715.6 & Shallow Bodrock & RCRA-WQMW \\
\hline 1242 & 17367.9 & 25344.8 & 775.1 & 777.3 & 27.3 & 11.3 & 26.3 & 763.8 & 748.8 & Shallow Bedrock & RFI-MW \\
\hline 1243 & 17085.6 & 25239.0 & 778.7 & 781.6 & 27.9 & 11.9 & 26.9 & 766.7 & 751.7 & Shallow Bedrock & RFI-MW \\
\hline
\end{tabular}

T/SCR \& B/SCR = Top and Boltom of Sereened Section 
Table 3.6. Interior groundwater guality monitorims well data

\begin{tabular}{|c|c|c|c|c|c|c|c|c|c|c|c|c|}
\hline \multirow{3}{*}{ Well : } & \multirow{2}{*}{\multicolumn{2}{|c|}{ ORNL grid location }} & \multirow{3}{*}{$\begin{array}{l}\text { Ground } \\
\text { elev. }\end{array}$} & \multirow{3}{*}{$\begin{array}{l}\text { Top } \\
\text { casing }\end{array}$} & \multirow{3}{*}{$\begin{array}{l}\text { Mens. } \\
\text { point }\end{array}$} & \multirow{3}{*}{$\begin{array}{l}\text { Total } \\
\text { depth }\end{array}$} & \multicolumn{4}{|c|}{ Screen inlervat } & \multirow{3}{*}{$\begin{array}{l}\text { Monitoring } \\
\text { interval sone }\end{array}$} & \multirow{3}{*}{ Une/Class } \\
\hline & & & & & & & \multicolumn{2}{|c|}{ Depoth } & \multicolumn{2}{|c|}{ Flevation } & & \\
\hline & North & Enst & & & & & T/SCR & $\mathrm{B} / \mathrm{SCR}$ & T/SCR & $\mathrm{B} / \mathrm{SCR}$ & & \\
\hline 1225 & 17754.8 & 24603.6 & 829.36 & 831.89 & 831.89 & 24.0 & 7.0 & 22.06 & 822.30 & 807.30 & Regolith & RFI-MW \\
\hline 1233 & 17005.3 & 24211.9 & 796.02 & 798.35 & 798.35 & 23.7 & 7.4 & 22.45 & 788.57 & 773.57 & Regolith/Bedrock & RFI-MW \\
\hline 1237 & 17089.1 & 23868.7 & 825.47 & 827.69 & 827.69 & 57.3 & 42.3 & 57.30 & 783.17 & 768.17 & Shallow Bedrock & RFI-MW \\
\hline 1241 & 17913.5 & 25097.6 & 805.70 & 808.24 & 808.24 & 35.9 & 14.9 & 34.90 & 790.80 & 770.80 & Regolith & RFI-MW \\
\hline 1166 & 17697.2 & 24945.9 & 806.75 & 808.95 & 808.95 & 39.0 & 16.7 & 36.74 & 790.01 & 770.01 & Shallow Bedrock? & TARA-PZ \\
\hline 845 & 17108.2 & 24988.3 & 807.33 & 810.30 & 811.23 & 41.0 & 19.2 & 39.90 & 788.13 & 767.43 & Regolith/Bedrock & RCRA-WQMW \\
\hline 848 & 16942.4 & 24656.3 & - & - & - & - & - & - & - & - & -- & - \\
\hline 849 & 16781.8 & 24215.2 & 787.68 & 791.18 & 791.48 & 32.9 & 10.5 & 32.60 & 777.18 & 755.08 & Regolith/Bedrock & RCRA-WQMW \\
\hline 850 & 16595.4 & 24793.5 & 769.98 & 771.36 & 772.08 & 22.7 & 6.0 & 21.70 & 763.98 & 748.28 & Regolith/Bodrock & RCRA-WQMW \\
\hline 851 & 16485.0 & 24058.2 & 766.36 & 769.15 & 770.16 & 21.6 & 4.0 & 20.00 & 762.36 & 746.36 & Regolith/Bedrock & RCRA-WQMW \\
\hline 852 & 16346.9 & 23911.6 & 767.55 & 769.68 & 770.65 & 25.3 & 5.4 & 21.50 & 762.15 & 746.05 & Regolith/Bedrock & RCRA-WQMW \\
\hline 854 & 16711.9 & 23851.9 & 781.48 & 783.23 & 784.68 & 27.5 & 5.0 & 27.30 & 776.48 & 754.18 & Regolith/Bodrock & RCRA-WQMW \\
\hline 648 & 17374.6 & 24524.2 & 823.42 & 824.73 & 824.73 & 45.0 & 35.0 & 45.00 & 788.42 & 778.42 & Shallow Bedrock & RAP-PZ \\
\hline 1036 & 16328.6 & 24231.1 & 767.98 & 771.90 & 771.90 & 26.7 & 13.0 & 23.00 & 754.98 & 744.98 & Regolith & TUMULUS-I \\
\hline 1039 & 16313.3 & 24093.3 & 765.40 & 768.28 & 768.28 & 17.6 & 6.5 & 11.50 & 758.90 & 753.90 & Regolith & TUMULUS-I \\
\hline
\end{tabular}

T/SCR \& B/SCR = Top and Bottom of Screened Section 
The spatial distribution of non-trench piezometers and monitoring wells for water level monitoring was chosen to provide sufficient density to record seasonal changes in the configuration of the water table. Consideration was given to screen depths for non-trench piezometers and wells to allow for determination of vertical gradients. The locations of all existing non-trench piezometers and monitoring wells which will be utilized for water level monitoring are listed in Table 3.7 and shown in Fig. 3.4.

Although the use of existing piezometers and wells was maximized, installation of new piezometers is required in areas that have insufficient spatial density or require the use of piezometers which have been damaged, are poorly constructed, or are otherwise not suitable. Table 3.8 lists the approximate coordinates and depth to bedrock of new non-trench piezometers. The depth to top of rock in Table 3.8 should be inferred as the probable maximum depth below ground surface that the piezometer will be installed. The new piezometers may utilize polyvinyl chloride (PVC) construction, as these piezometers will not be used for water quality monitoring. In addition to the new piezometers, the new water quality wells addressed in Sect. 3.1.1.3 will also be used for water level measurements.

Trench piezometers selected for monitoring were chosen to include trenches within all the waste disposal areas at WAG 6, utilizing existing piezometers. Consideration also was given to the hydrologic

class of the trenches. It was assumed that those trenches that are currently dry will continue to be dry, and these were eliminated from consideration for water level monitoring. Table 3.9 lists the hydrologic class for each of the trench piezometers and the data source used to make the classification. The intermittently and perennially bathtubbing trenches have been combined into a single class. Table 3.10 lists the original identification, the identification in current use, and the locations and elevations of the trench piezometers to be utilized for the EMP. Trench piezometer locations are shown in Fig. 3.5. Table 3.11 lists the piezometers that have been selected for continuous water level monitoring.

By selecting trench piezometers inside the ICM caps for monitoring, it is possible to continue evaluation of the effectiveness of the ICM caps. The trench piezometers in uncapped trenches provide the minimum network necessary for evaluation of the areal extent of water table inundation of the trenches.

\subsubsection{Meteorologieal monitoring location}

The tumulus meteorology station will be used for this effort. The station is located $-100 \mathrm{ft}$ south of the uumulus disposal facility. The location of the meteorological tower is such that it will provide representative measurements of the local air flow patterns in WAG 6. The location of the tower meets EPA specifications of no surface obstruction located within a distance of 10 times the height of the instrument. This minimizes the probability of any air flow obstructions or artificially induced turbulence.

\subsection{Sample Collection Methods}

This section presents the various sample collection methods that will be used to monitor the conditions at WAG 6 . These methods cover all four environmental media: surface water, seeps and springs, and groundwater. Specific procedures for performing sample collection activities are provided in more detail in the SAPs. 
Table 3.7. Data for existing piesometers and monitoring wells

\begin{tabular}{|c|c|c|c|c|c|c|c|c|c|c|}
\hline \multirow[b]{3}{*}{ Well * } & & & \multirow{3}{*}{$\begin{array}{l}\text { Ground } \\
\text { elov. }\end{array}$} & \multirow{3}{*}{$\begin{array}{l}\text { Meas. } \\
\text { point }\end{array}$} & \multirow{3}{*}{$\begin{array}{l}\text { Total } \\
\text { depth }\end{array}$} & \multicolumn{4}{|c|}{ Screen interval } & \multirow[b]{3}{*}{ Interval zone } \\
\hline & \multicolumn{2}{|c|}{ ORNL grid location } & & & & \multicolumn{2}{|c|}{ Depth } & \multicolumn{2}{|c|}{ Elevation } & \\
\hline & North & Enst & & & & T/SCR & B/SCR & T/SCR & B/SCR & \\
\hline $\begin{array}{l}347 \\
367 \\
374 \\
376 \\
377 \\
379 \\
382 \\
383 \\
385 \\
399 \\
401 \\
636 \\
637 \\
638 \\
641 \\
644 \\
647 \\
648 \\
650 \\
652 \\
656 \\
835 * \\
836^{*} \\
837^{*} \\
838^{*} \\
840^{*} \\
842 * \\
843^{*} \\
844^{*} \\
845 \\
846 * \\
847^{*}\end{array}$ & $\begin{array}{l}16545.0 \\
17723.0 \\
17462.0 \\
16584.0 \\
16610.0 \\
16156.0 \\
15814.0 \\
16165.0 \\
17903.0 \\
16881.3 \\
17022.3 \\
17668.0 \\
17715.1 \\
17495.1 \\
17383.5 \\
16748.9 \\
17145.7 \\
17374.6 \\
17273.9 \\
16159.7 \\
17923.9 \\
15767.7 \\
15748.2 \\
15845.6 \\
16308.7 \\
16928.6 \\
17216.1 \\
17597.1 \\
17602.5 \\
17108.2 \\
18030.7 \\
17769.9\end{array}$ & $\begin{array}{l}24602.0 \\
25091.0 \\
25346.0 \\
23479.0 \\
23297.0 \\
23206.0 \\
24025.0 \\
24895.0 \\
24669.0 \\
24349.5 \\
24380.2 \\
24326.2 \\
24136.0 \\
24119.4 \\
23985.2 \\
24848.4 \\
24749.0 \\
24524.2 \\
25150.6 \\
24900.0 \\
24693.0 \\
23951.8 \\
24138.8 \\
24352.6 \\
24934.8 \\
25251.7 \\
25298.4 \\
25221.4 \\
25228.6 \\
24988.3 \\
24803.5 \\
24790.5\end{array}$ & $\begin{array}{l}777.1 \\
841.7 \\
781.3 \\
806.5 \\
836.8 \\
792.1 \\
763.3 \\
769.4 \\
841.3 \\
800.1 \\
8-1 \\
833.0 \\
859.4 \\
848.4 \\
843.8 \\
776.3 \\
816.7 \\
823.4 \\
817.1 \\
770.2 \\
847.6 \\
759.9 \\
763.3 \\
771.1 \\
752.3 \\
766.9 \\
767.3 \\
781.4 \\
781.0 \\
807.3 \\
861.0 \\
839.6\end{array}$ & $\begin{array}{l}778.7 \\
844.2 \\
783.5 \\
809.5 \\
839.8 \\
793.0 \\
765.7 \\
771.5 \\
843.8 \\
800.1 \\
-5 \\
834.7 \\
861.6 \\
849.9 \\
845.8 \\
776.2 \\
820.4 \\
824.7 \\
820.1 \\
769.8 \\
847.8 \\
762.9 \\
767.3 \\
774.5 \\
755.1 \\
770.9 \\
770.1 \\
783.9 \\
784.8 \\
811.2 \\
865.0 \\
843.1\end{array}$ & $\begin{array}{r}12.6 \\
69.0 \\
31.0 \\
35.0 \\
56.0 \\
37.0 \\
21.0 \\
33.0 \\
45.0 \\
28.6 \\
28.9 \\
54.0 \\
66.0 \\
70.0 \\
60.0 \\
17.0 \\
36.0 \\
45.0 \\
60.0 \\
90.0 \\
120.0 \\
27.5 \\
28.5 \\
31.6 \\
22.8 \\
26.9 \\
26.8 \\
21.0 \\
52.0 \\
41.0 \\
81.0 \\
67.0\end{array}$ & $\begin{array}{r}59.0 \\
21.0 \\
25.0 \\
46.0 \\
27.0 \\
11.0 \\
23.0 \\
35.0 \\
23.6 \\
59 \\
39.0 \\
49.0 \\
55.0 \\
45.0 \\
7.0 \\
26.0 \\
35.0 \\
52.0 \\
70.0 \\
100.0 \\
5.5 \\
7.0 \\
10.0 \\
5.0 \\
11.0 \\
8.0 \\
3.6 \\
24.6 \\
19.2 \\
55.0 \\
45.4\end{array}$ & $\begin{array}{l}6 \overline{69.0} \\
31.0 \\
35.0 \\
56.0 \\
37.0 \\
21.0 \\
33.0 \\
45.0 \\
28.6 \\
54 \\
54.0 \\
66.0 \\
70.0 \\
60.0 \\
17.0 \\
36.0 \\
45.0 \\
60.0 \\
90.0 \\
120.0 \\
26.9 \\
28.2 \\
31.3 \\
21.5 \\
26.6 \\
23.2 \\
19.3 \\
51.7 \\
39.9 \\
81.0 \\
65.8\end{array}$ & $\begin{array}{l}782.7 \\
760.3 \\
781.5 \\
790.8 \\
765.1 \\
752.3 \\
746.4 \\
806.3 \\
776.6 \\
79-1 \\
794.0 \\
810.4 \\
793.4 \\
798.8 \\
769.3 \\
790.7 \\
788.4 \\
765.1 \\
700.2 \\
747.6 \\
754.4 \\
756.3 \\
761.1 \\
747.3 \\
755.9 \\
759.3 \\
777.8 \\
756.4 \\
788.1 \\
806.0 \\
794.2\end{array}$ & \begin{tabular}{|l}
$\mathbf{7 7 2 . 7}$ \\
750.3 \\
771.5 \\
780.8 \\
755.1 \\
742.3 \\
736.4 \\
796.3 \\
771.6 \\
$-\overline{779.0}$ \\
793.4 \\
778.4 \\
783.8 \\
759.3 \\
780.7 \\
778.4 \\
757.1 \\
680.2 \\
727.6 \\
733.0 \\
$\mathbf{7 3 5 . 1}$ \\
$\mathbf{7 3 9 . 8}$ \\
$\mathbf{7 3 0 . 8}$ \\
$\mathbf{7 4 0 . 3}$ \\
$\mathbf{7 4 4 . 1}$ \\
$\mathbf{7 6 2 . 1}$ \\
$\mathbf{7 2 9 . 3}$ \\
$\mathbf{7 6 7 . 4}$ \\
$\mathbf{7 8 0 . 0}$ \\
$\mathbf{7 7 3 . 8}$
\end{tabular} & $\begin{array}{c}\text { Regolith } \\
\text { Shallow Bedrock } \\
\text { Shallow Bedrock } \\
\text { Bedrock/Regolith } \\
\text { Regolith } \\
\text { Shallow Bedrock } \\
\text { Regolith/Bedrock } \\
\text { Shallow Bedrock } \\
\text { Shallow Bedrock } \\
\text { Regolith/Bedrock } \\
\text { Regolith/Bedrock } \\
\text { Shallow Bodrock } \\
\text { Shallow Bodrock } \\
\text { Shallow Bedrock } \\
\text { Shallow Bodrock } \\
\text { Shallow Bedrock } \\
\text { Shallow Bedrock } \\
\text { Shallow Bedrock } \\
\text { Shallow Bedrock } \\
\text { Deep Bedrock } \\
\text { Deep Bedrock } \\
\text { Regolith } \\
\text { Regolith } \\
\text { Regolith } \\
\text { Regolith/Bedrock } \\
\text { Shallow Bedrock } \\
\text { Shallow Bedrock } \\
\text { Regolith/Bedrock } \\
\text { Shallow Bedrock } \\
\text { Regolith/Bedrock } \\
\text { Shallow Bedrock } \\
\text { Shallow Bedrock }\end{array}$ \\
\hline
\end{tabular}


Table 3.7 (continued)

\begin{tabular}{|c|c|c|c|c|c|c|c|c|c|c|}
\hline \multirow[b]{3}{*}{ Well } & & & \multirow{3}{*}{$\begin{array}{l}\text { Ground } \\
\text { elov. }\end{array}$} & \multirow{3}{*}{$\begin{array}{l}\text { Meas. } \\
\text { point }\end{array}$} & \multirow{3}{*}{$\begin{array}{l}\text { Total } \\
\text { depth }\end{array}$} & \multicolumn{4}{|c|}{ Screen interval } & \multirow[b]{3}{*}{ Interval zone } \\
\hline & \multicolumn{2}{|c|}{ ORNL grid location } & & & & \multicolumn{2}{|c|}{ Depth } & \multicolumn{2}{|c|}{ Elovation } & \\
\hline & North & Enst & & & & T/SCR & B/SCR & T/SCR & B/SCR & \\
\hline $\begin{array}{r}848 \\
849 \\
850 \\
851 \\
852 \\
853 \\
854 \\
1036 \\
1037 \\
1039 \\
1166 \\
1225 \\
1233 \\
1234 \\
1236 \\
1237 \\
1238 \\
1240 \\
1241 \\
1242 * \\
1243 * \\
1254 \\
1257 \\
1258 \\
936+ \\
937+ \\
938+ \\
939+ \\
940+ \\
941+ \\
945+ \\
999+ \\
1000+\end{array}$ & $\begin{array}{l}16942.4 \\
16781.8 \\
16595.4 \\
16485.0 \\
16346.9 \\
16695.1 \\
16711.9 \\
16328.6 \\
16228.1 \\
16313.3 \\
17697.2 \\
17754.8 \\
17005.3 \\
16956.9 \\
16195.3 \\
17089.1 \\
17079.0 \\
18066.2 \\
17913.5 \\
17367.9 \\
17085.6 \\
16434.1 \\
16493.3 \\
16409.2 \\
16144.6 \\
16148.2 \\
16170.6 \\
15814.8 \\
15827.6 \\
15833.5 \\
17540.7 \\
17518.9 \\
17498.4\end{array}$ & $\begin{array}{l}24656.3 \\
24215.2 \\
24793.5 \\
24058.2 \\
23911.6 \\
24047.5 \\
23851.9 \\
24231.1 \\
24175.7 \\
24093.3 \\
24945.9 \\
24603.7 \\
24211.9 \\
25249.1 \\
23195.5 \\
23868.7 \\
23862.4 \\
25183.9 \\
25097.6 \\
25344.8 \\
25239.0 \\
24112.8 \\
24251.2 \\
24248.1 \\
24609.8 \\
24688.4 \\
24676.1 \\
24525.3 \\
24595.3 \\
24561.1 \\
24512.1 \\
24509.4 \\
24506.6\end{array}$ & $\begin{array}{l}- \\
787.7 \\
777.0 \\
766.4 \\
767.6 \\
780.4 \\
781.5 \\
768.0 \\
771.1 \\
765.4 \\
806.8 \\
829.4 \\
796.0 \\
772.3 \\
801.6 \\
825.5 \\
824.9 \\
797.7 \\
805.7 \\
775.1 \\
778.7 \\
766.6 \\
777.8 \\
776.9 \\
790.4 \\
787.8 \\
\mathbf{7 8 7 . 9} \\
\mathbf{7 6 7 . 5} \\
766.4 \\
766.8 \\
808.5 \\
808.6 \\
808.8\end{array}$ & $\begin{array}{l}- \\
791.5 \\
7772.1 \\
770.2 \\
770.7 \\
784.4 \\
784.7 \\
771.9 \\
774.6 \\
768.3 \\
809.0 \\
831.9 \\
798.4 \\
774.6 \\
803.9 \\
827.7 \\
827.2 \\
800.3 \\
808.2 \\
777.3 \\
781.6 \\
768.9 \\
779.6 \\
779.0 \\
793.9 \\
792.1 \\
791.7 \\
770.3 \\
770.0 \\
770.7 \\
811.9 \\
810.5 \\
810.7\end{array}$ & $\begin{array}{r} \\
32.9 \\
22.7 \\
21.6 \\
25.3 \\
27.7 \\
27.5 \\
26.7 \\
26.2 \\
17.6 \\
39.0 \\
24.0 \\
23.7 \\
149.2 \\
161.8 \\
57.3 \\
152.0 \\
23.6 \\
35.9 \\
27.3 \\
27.9 \\
17.5 \\
23.1 \\
25.0 \\
400.4 \\
215.3 \\
61.5 \\
400.4 \\
219.5 \\
63.0 \\
402.5 \\
295.0 \\
178.0\end{array}$ & $\begin{array}{r}10.5 \\
6.0 \\
4.0 \\
5.4 \\
4.5 \\
5.0 \\
13.0 \\
12.3 \\
6.5 \\
16.7 \\
7.1 \\
7.5 \\
128.2 \\
140.8 \\
42.3 \\
131.0 \\
7.6 \\
14.9 \\
11.3 \\
11.9 \\
12.5 \\
13.1 \\
15.0 \\
380.0 \\
174.3 \\
40.8 \\
380.0 \\
196.1 \\
42.1 \\
380.0 \\
275.0 \\
158.0\end{array}$ & $\begin{array}{r}- \\
32.6 \\
21.7 \\
20.0 \\
21.5 \\
25.8 \\
27.3 \\
23.0 \\
22.3 \\
11.5 \\
36.7 \\
22.1 \\
22.5 \\
148.2 \\
160.8 \\
57.3 \\
151.0 \\
22.6 \\
34.9 \\
26.3 \\
26.9 \\
17.5 \\
23.1 \\
25.0 \\
400.0 \\
215.3 \\
61.5 \\
400.0 \\
219.5 \\
63.0 \\
400.0 \\
295.0 \\
178.0\end{array}$ & $\begin{array}{l}7 \overline{777.2} \\
764.0 \\
762.4 \\
762.2 \\
775.9 \\
776.5 \\
755.0 \\
758.8 \\
758.9 \\
792.0 \\
822.3 \\
788.6 \\
644.1 \\
660.8 \\
783.2 \\
693.9 \\
790.1 \\
790.8 \\
763.8 \\
766.7 \\
754.1 \\
764.7 \\
761.9 \\
410.4 \\
613.5 \\
747.1 \\
387.5 \\
570.4 \\
724.7 \\
428.5 \\
533.6 \\
650.8\end{array}$ & $\begin{array}{l}- \\
755.1 \\
748.3 \\
746.4 \\
746.1 \\
754.6 \\
754.2 \\
745.0 \\
748.8 \\
753.9 \\
770.0 \\
807.3 \\
773.6 \\
624.1 \\
640.8 \\
768.2 \\
673.9 \\
775.1 \\
770.8 \\
748.8 \\
751.7 \\
749.1 \\
754.7 \\
751.9 \\
390.4 \\
572.5 \\
726.4 \\
367.5 \\
547.0 \\
703.8 \\
408.5 \\
513.6 \\
630.8\end{array}$ & $\begin{array}{c}\text { Shallow Bedrock } \\
\text { Regolith/Bedrock } \\
\text { Reoplith/Bodrock } \\
\text { Regolith/Bodrock } \\
\text { Regolith/Bedrock } \\
\text { Regolith/Bedrock } \\
\text { Regolith/Bedrock } \\
\text { Regolith } \\
\text { Regolith } \\
\text { Regolith } \\
\text { Shallow Bedrock } \\
\text { Regolith } \\
\text { Regolith/Bedrock } \\
\text { Deep Bedrock } \\
\text { Deep Bedrock } \\
\text { Shallow Bedrock } \\
\text { Deep Bedrock } \\
\text { Shallow Bedrock } \\
\text { Regolith } \\
\text { Shallow Bedrock } \\
\text { Shallow Bedrock } \\
\text { Regolith } \\
\text { Regolith } \\
\text { Regolith } \\
\text { Deep Bedrock } \\
\text { Deep Bedrock } \\
\text { Shallow Bedrock } \\
\text { Deep Bedrock } \\
\text { Deep Bedrock } \\
\text { Shallow Bedrock } \\
\text { Deep Bedrock } \\
\text { Deep Bedrock } \\
\text { Shallow Bedrock }\end{array}$ \\
\hline
\end{tabular}




\begin{tabular}{|c|c|c|c|c|c|c|c|c|c|c|}
\hline \multirow[b]{3}{*}{ Well * } & & & \multirow{3}{*}{$\begin{array}{l}\text { Ground } \\
\text { elev. }\end{array}$} & \multirow{3}{*}{$\begin{array}{c}\text { Meas. } \\
\text { point }\end{array}$} & \multirow{3}{*}{$\begin{array}{l}\text { Total } \\
\text { deptin }\end{array}$} & \multicolumn{4}{|c|}{ Sereen interval } & \multirow[b]{3}{*}{ Interval zono } \\
\hline & \multicolumn{2}{|c|}{ ORNL grid location } & & & & \multicolumn{2}{|c|}{ Depth } & \multicolumn{2}{|c|}{ Elovation } & \\
\hline & North & Enst & & & & T/SCR & B/SCR & T/SCR & B/SCR & \\
\hline $\begin{array}{l}1001+ \\
1002+ \\
1003+ \\
1659 \\
1671 \\
1672 \\
1673 \\
2469\end{array}$ & $\begin{array}{l}16862.0 \\
16810.7 \\
16782.5 \\
16756.0 \\
16872.0 \\
16849.2 \\
16841.4 \\
17627.7 \\
\end{array}$ & $\begin{array}{l}24694.8 \\
24697.1 \\
24668.2 \\
23641.2 \\
23596.3 \\
23618.5 \\
23603.5 \\
24620.8 \\
\end{array}$ & $\begin{array}{l}786.1 \\
783.5 \\
786.1 \\
809.2 \\
805.0 \\
805.6 \\
827.8 \\
\end{array}$ & $\begin{array}{l}788.0 \\
785.6 \\
788.6 \\
812.3 \\
807.1 \\
807.3 \\
829.2 \\
\end{array}$ & $\begin{array}{r}400.0 \\
197.0 \\
79.0 \\
28.7 \\
250.7 \\
94.6 \\
46.8 \\
45.3 \\
\end{array}$ & $\begin{array}{r}240.7 \\
84.6 \\
36.8 \\
30.3 \\
\end{array}$ & $\begin{array}{r}400.0 \\
197.0 \\
79.0 \\
\\
250.7 \\
94.6 \\
46.8 \\
45.3 \\
\end{array}$ & $\begin{array}{l}406.1 \\
606.5 \\
727.1 \\
\\
568.5 \\
720.4 \\
768.8 \\
797.5 \\
\end{array}$ & $\begin{array}{l}386.1 \\
586.5 \\
707.1 \\
\\
558.5 \\
710.4 \\
758.8 \\
782.5 \\
\end{array}$ & $\begin{array}{l}\text { Deep Bedrock } \\
\text { Deep Bedrock } \\
\text { Shallow Bedrock } \\
\text { Regolith/Bedrock } \\
\text { Deep Bedrock } \\
\text { Shallow Bedrock } \\
\text { Shallow Bedrock } \\
\text { Shallow Bedrock }\end{array}$ \\
\hline
\end{tabular}

- $=$ RCRA well used as piezometer. $+=$ Hydnulic head monitoring station. T/SCR \& B/SCR $=$ Top and Bothom of Screened Section 


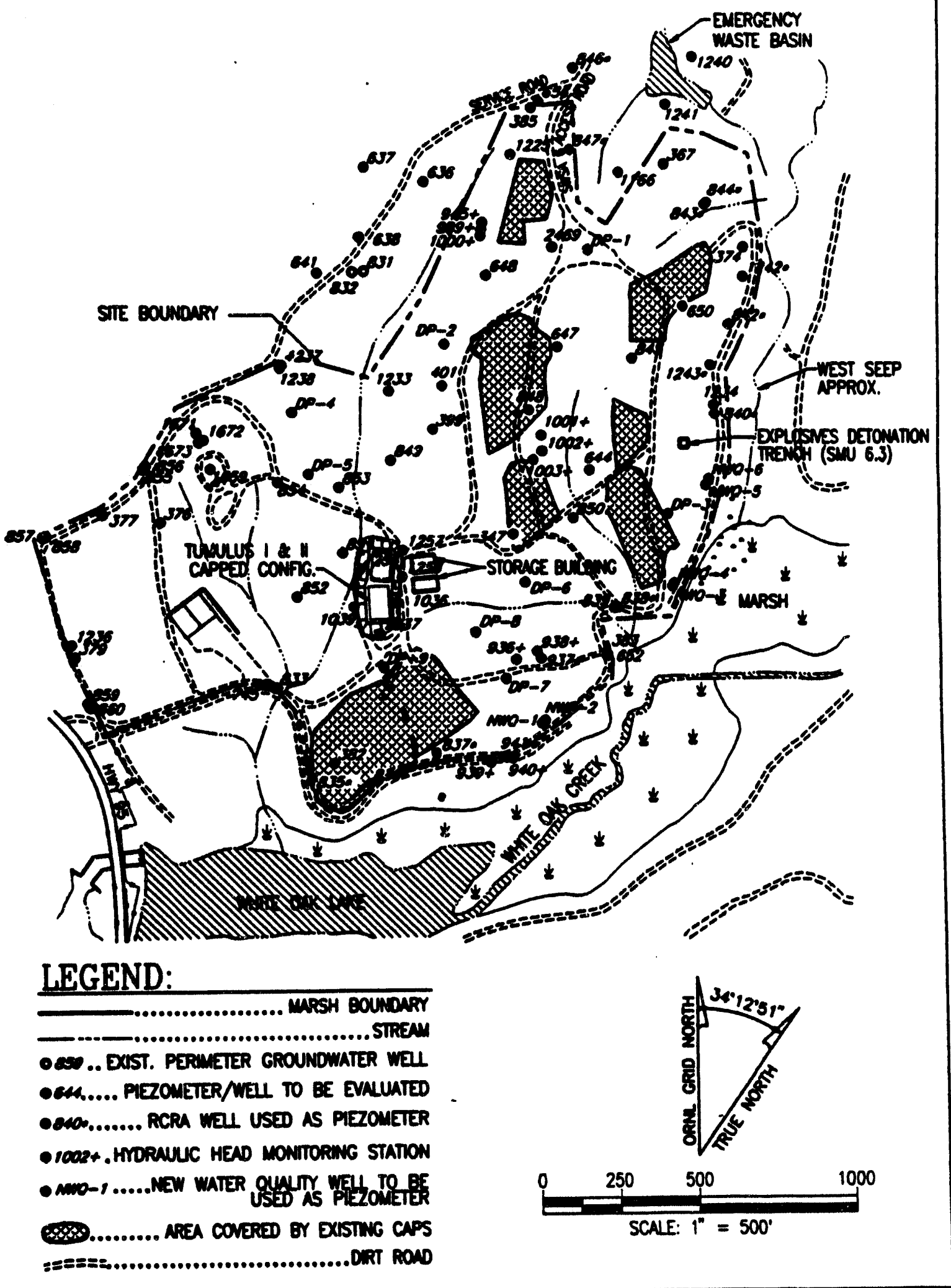

G:\93053 ECE WE-PZ

Fig. 3.4. Location of non-trench piezometers and wells. 
Table 3.8. Proposed new non-trench piesometer locations

\begin{tabular}{cccc}
\hline Well * & Northing & Easting & Top of rock \\
\hline DP-1 & 17455.0 & 24850.0 & 16 \\
DP-2 & 17156.0 & 24390.0 & 30 \\
DP-3 & 16607.0 & 25096.0 & 37 \\
DP-4 & 16937.0 & 23900.0 & 25 \\
DP-5 & 16738.0 & 23951.0 & 12 \\
DP-6 & 16391.0 & 24640.0 & 17 \\
DP-7 & 16084.0 & 24577.0 & 35 \\
DP-8 & 16232.0 & 24481.0 & 39 \\
DP-9 & 16120.0 & 24188.0 & 39 \\
\hline
\end{tabular}

Top of rock in feet below ground surface. Depths are approximated from the depth of the closeat bedrock well and are sccurnte to $\sim 10 \mathrm{t}$. 


\section{3-18}

Table 3.9. WAG 6 trench piezometer hydrologic class

\begin{tabular}{cccc}
\hline Well ID & Well I & Hydrologic class & Data source \\
\hline T82 & 2522 & II & a,c \\
T444 & 2528 & II & c \\
T69 & 2529 & II & a,c \\
T363 & 2263 & II & a,c \\
C2-X1 & 2409 & PI & c \\
T85 & 2349 & PI & a,c \\
T105 & 2084 & PI & a,c \\
T101 & 2083 & Bathtubbing & a,c \\
T329 & 2256 & II & a,c \\
T44 & 2290 & II & a,c \\
T60 & 2305 & II & a,c \\
T63 & 2306 & II & a,c \\
T260-1 & 2209 & PI & b \\
T279-1 & 2217 & PI & a \\
T279-5 & 2221 & PI & a \\
T304 & 2252 & II & b \\
T145 & 2117 & PI & a \\
T203 & 2202 & II & b \\
T133 & 2105 & Bathtubbing & b \\
T198 & 2190 & Bathtubbing & b \\
T19 & 2479 & Silo Well & - \\
T40 & 2499 & Silo Well & - \\
T44 & 2503 & Silo Well & - \\
T11 & 2472 & Silo Well & - \\
T30 & 2489 & Silo Well & - \\
AUG-48 & 4018 & Auger Hole Well & - \\
T92-2 & 2365 & PI & c \\
T35 & 2260 & Bathtubbing & a \\
Tis & 259 & \\
\hline
\end{tabular}

Miraing data unavailable at the time of publication.

$D=$ Dry

II = Intermituently Inundated

PI = Perennially Inundated

Buthtubbing

$a=\mathrm{R}$ report (BNI 1991)

b = Inferred from figures contained in $\mathbf{R J}$

$c=$ Clapp 1992 
Table 3.10. WAG 6 trench monitoring piezometer data

\begin{tabular}{|c|c|c|c|c|c|c|}
\hline \multirow{2}{*}{ Well ID } & \multirow{2}{*}{ Well * } & \multicolumn{2}{|c|}{ ORNL grid location } & \multirow{2}{*}{$\begin{array}{l}\text { Top of } \\
\text { casing }\end{array}$} & \multirow{2}{*}{$\begin{array}{l}\text { Ground } \\
\text { surface }\end{array}$} & \multirow{2}{*}{$\begin{array}{l}\text { Depth below } \\
\text { land surface } \\
\text { (ft) }\end{array}$} \\
\hline & & North & Enst & & & \\
\hline $\mathrm{T} 82$ & 2522 & 17702.0 & 24641.0 & 832.5 & 830.7 & 13.19 \\
\hline T444 & 2528 & 17660.0 & 24715.0 & 837.5 & 835.1 & 13.29 \\
\hline T69 & 2529 & 16870.0 & 24565.0 & 798.3 & 796.5 & 10.37 \\
\hline T363 & 2263 & 16989.0 & 24567.0 & 803.4 & 801.9 & 12.40 \\
\hline$C 2-X_{1}$ & 2409 & 17192.5 & 24618.9 & - & 823.5 & 17.4 \\
\hline $\mathbf{T} 85$ & 2349 & 16638.0 & 24614.0 & 784.2 & 782.6 & 10.50 \\
\hline T105 & 2084 & 16574.0 & 24642.0 & 781.0 & 779.4 & 10.11 \\
\hline T101 & 2083 & 16423.0 & 25037.0 & 763.9 & 762.8 & 10.93 \\
\hline T329 & 2256 & 16678.0 & 24922.0 & 777.5 & 774.9 & 9.91 \\
\hline T44 & 2290 & 15809.0 & 23965.0 & 763.2 & 761.4 & 14.96 \\
\hline$T 60$ & 2305 & 15700.0 & 24053.0 & 763.1 & 761.1 & 11.39 \\
\hline T63 & 2306 & 15873.0 & 24026.0 & 763.9 & 762.0 & 14.60 \\
\hline T260-1 & 2209 & 16575.7 & 23906.9 & - & 779.9 & - \\
\hline T279-1 & 2217 & 16490.1 & 23962.6 & - & 777.6 & 8.37 \\
\hline T279-5 & 2221 & 16448.6 & 23961.1 & - & 775.5 & 6.97 \\
\hline T304 & 2252 & 16967.3 & 23857.0 & - & 804.6 & 19.2 \\
\hline T145 & 2117 & 16824.9 & 24232.7 & - & 791.3 & 12.31 \\
\hline $\mathbf{T 2 0 3}$ & 2202 & 16773.1 & 24007.8 & - & 786.4 & 18.0 \\
\hline T133 & 2105 & 17015.0 & 24351.2 & - & - & 14.01 \\
\hline T198 & 2190 & 16866.6 & 24427.0 & $\cdot$ & - & 10.33 \\
\hline T19 & 2479 & 17175.4 & 24341.8 & - & - & 23.00 \\
\hline $\mathbf{S 1 1}$ & 2469 & 17627.7 & 24620.8 & 829.2 & 827.8 & 45.30 \\
\hline $\mathrm{T} 40$ & 2499 & 16051.5 & 24461.5 & - & $\cdot$ & 25.00 \\
\hline $\mathrm{T} 44$ & 2503 & 16086.6 & 24448.7 & - & - & 23.00 \\
\hline T11 & 2472 & 17139.3 & 24359.0 & - & - & 17.5 \\
\hline$T-30$ & 2489 & 17445.4 & 24642.9 & $\cdot$ & - & 20.0 \\
\hline AUG-48 & 4018 & 17120.0 & 24999.0 & - & - & 6.95 \\
\hline T92-2 & 2365 & 16728.0 & 24615.0 & - & - & 11.15 \\
\hline T35 & 2260 & 17020.2 & 24279.8 & - & 804.2 & 12.34 \\
\hline
\end{tabular}

Misuing data unavailable at the time of publication. 


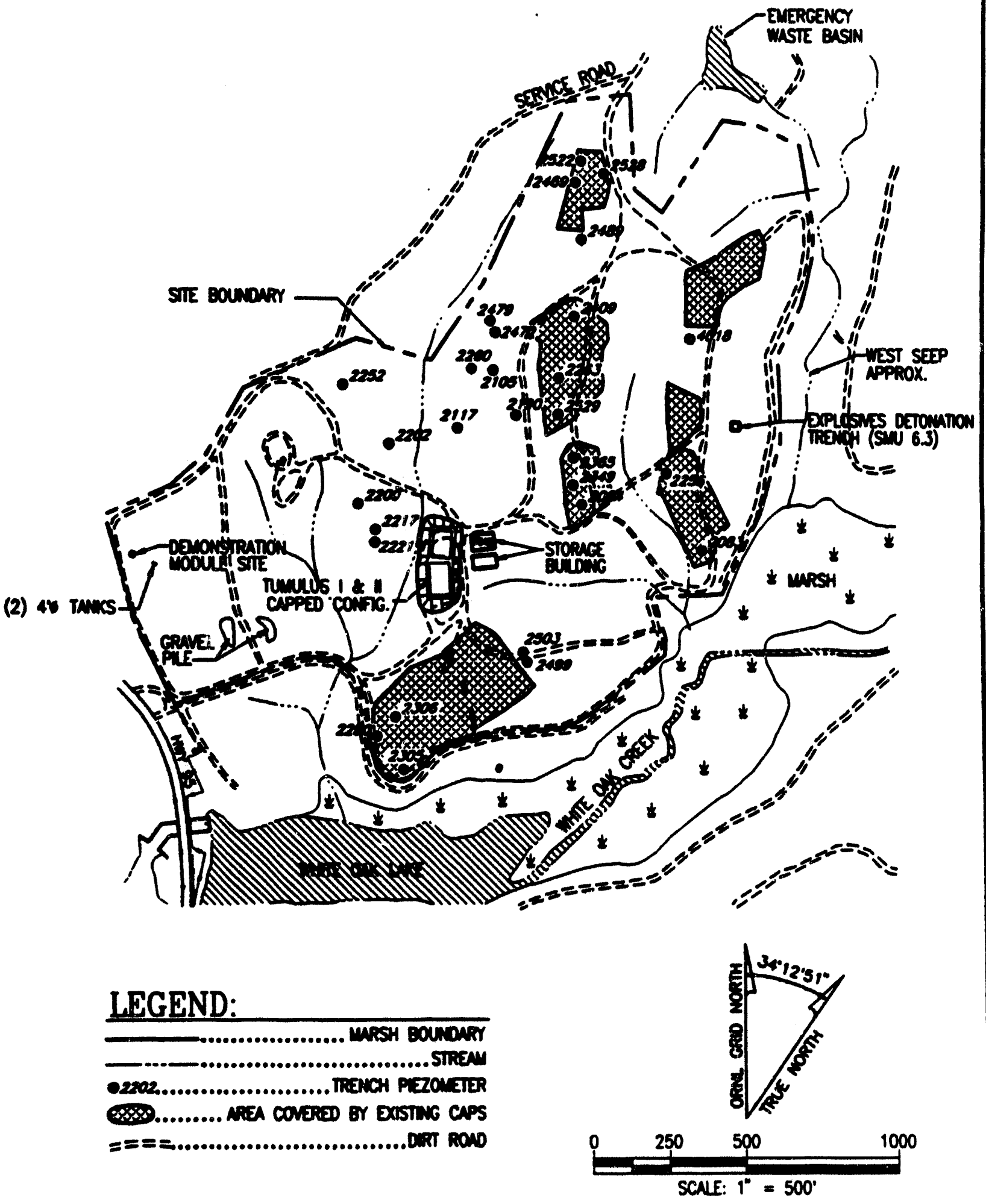

Fig. 3.5. Locations of trench piezometers. 
Table 3.11. Piesometers to be equipped for continuous monitoring

\begin{tabular}{|c|c|c|}
\hline Group & Type & Woll number \\
\hline Treach pierometers & Water lovel & $\begin{array}{l}2252,2202,2209,2217,2522,2528,2469 \\
2489,2479,2472,2260,2105,2190,2305 \\
2499,2503,2349,2365,2529,2263,2409 \\
4018,2256,2083\end{array}$ \\
\hline Non-trench piezometers & Water level & $\begin{array}{l}848,347,644,382,1225,2469,851,845 \\
399,401, \text { DP2, DP3, DP4, DPS, DP7 }\end{array}$ \\
\hline Other piesometers & $\begin{array}{l}\text { Water lovel conductivity } \\
\text { temperature }\end{array}$ & $\begin{array}{l}2117,2221,2306,2290,2084,835,836,837, \\
\text { WOL }\end{array}$ \\
\hline
\end{tabular}

- WOL will be monitored as part of this functional group.

\subsubsection{Surface water monitoring}

The various types of surface water data that will be collected as part of the EMP include:

- surface water flow measurements from gaged monitoring points,

- flow-proportional surface water quality data from gaged monitoring points,

- discrete (i.e., base flow and storm event) surface water quality data from gaged and ungaged monitoring points,

- data for defining the C-Q relationships, and

- bedload sediment radionuclide concentrations.

Continuous Flow Measurements. Continuous flow measurements will be collected via electronic water level sensors and programmable data loggers at the hydraulic structure (i.e., flume or weir) located - at each of the three major perimeter monitoring stations. The level sensor will measure the stage height and aransmit this information to the data logger, which translates the stage measurement into a discharge value using a preprogrammed rating table established for the hydraulic structure. Electronic measurements will be verified periodically by field personnel through manual water level and timedvolumetric discharge measuremeats.

Flow-paced Water Quality Sampling. Flow-paced water quality sampling is a standard data collection technique that has been used extensively at monitoring stations in the WOC basin. An automatic sampler collects an aliquot of water from the stream and delivers it to a large container. This occurs every time that an incremental volume of water has passed the monitoring site. An electronic data logger tabulates the discharge and water volume, activates the sampler, and records aliquot collection times. This process continues until the composite container is filled or retrieved by field personnel. The amount of sample collected in the container is determined by the aliquot volume, the incremental flow volume between aliquots, and the time-varying stream discharge. The stream flow cannot be known in advance, therefore it follows that the volume of the composite sample is variable and dependent on the stream hydrograph.

Monitoring locations designated as flow-paced sampling sites will be equipped with automatic samplers for continuous sample collection. Sample collection containers must be retrieved weekly to prevent overfilling. Weekly samples will not be analyzed separately. To reduce the analytical cost of 
this program, each weekly sample collected at a site during each month will be combined into one monthly composite sample.

Flow-paced amples are prepared by mixing the water contained in the container that has been retrieved from the field, immediately decanting the amount of mixed sample needed for analysis, and performing the desired analytical procedures. Therefore, the concentration of contaminant obtained through analysis of the mixed sample is the flow-proportional concentration for the time period during which aliquots were collected in the container.

Grab Storm Flow Sampling. Monitoring ungaged drainages requires the grab storm flow sampling approach. This methcd is ideal for monitoring stations that discharge only during storm events because if does not require the maintenance of costly and cumbersome equipment on \& continuous basis. All grab storm flow sumples must be collected manually. In general, the objectives for grab storm flow sampling are similar to that stated for automatic storm flow sampling (i.e., obtain sequential storm flow samples, evenly distributed over the runoff hydrograph of the avent). Sample coverage of the entire hydrograph will require that field personnel arrive onsite prior to the start of runoff conditions, and collect multiple amples during storm flow. The samples appropriate for analysis can be selected after all samples are collected.

Automatic Storm Now Sampling. Automatic storm flow sampling will be performed at the main gazed sites. The main purpose for implementing the automatic storm flow sampling method is to collect the mid-range and high flow sample data required for establishment of $\mathrm{C}-\mathrm{Q}$ relationships. These data, along with corresponding flow measurements, can indicate whether contaminants are moving by shallow pathways or deeper groundwater pathways during storm flow conditions.

As indicated by the name of this method, these samples will be collected using programmable automatic samplers. A sampler will remain inactive during dry weather conditions until a programmable data logger, located onsite with a level sensor, encounters a preprogrammed water level above base flow. At this point the logger activates the sampler and sample collection proceeds according to the sampler's program. Samples are collected into individual bottles at discrete, preprogrammed time intervals. This process continues until all sample bottles contained in the sampler are filled. The number of samples that can be collected by a sampler varies depending upon the bottle size.

Ideally, the storm flow samples collected using this method will be distributed evenly over the entire runoff hydrograph of the storm. Every effort should be made during sampler programming to collect as many samples as possible throughout the runoff hydrograph (i.e., before, during, and after the peak flow). However, the shape and timing of individual runoff hydrographs cannot be known in advance, thus it is difficult to sample evenly all portions of the runoff event. Sample coverage of the hydrograph can be refined through adjustment of the sampler activation level and the sample collection interval, based upon site runoff characteristics (e.g., basin size, travel times, storm flow component timing) and seasonal base flow and runoff treads. Initially, these values will be determined through examination of sitespecific historical storm flow data. Adjustments to these parameters to obtain better sample coverage of a runoff event will be made after field personnel become more experienced with the site-specific flow characteristics.

Automatic storm flow sampling will occur frequently during the baseline monitoring period in an effort to provide enough seasonal variation in the data to establish and evaluate $C-Q$ relationships for the 
COCs. If the relationships derived from these samples are judged to be useful, then the frequency of automatic storm flow sampling can be reduced.

Grab Base Flow Sampling. The main purpose for using the grab base flow sampling method is to provide the low-flow/high concentration data needed to adequately establish $C-Q$ relationships. Grab base - flow sampling is also required for analytes with short analytical holding times or physical limitations that invalidate the use of flow-paced sample collection techniques.

All grab base flow samples will be collected manually. To ensure that sampling occurs during true base flow conditions, the following requirements must be met for sampling to be performed.

- a least 72 hours must have passed with $<0.1$ in. of rainfall, and

- stream flow at the sample site is generally at base flow levels (i.e., consistent with previous censonal observations during periods of no rainfall).

All grab anmple collection will be coordinated such that base flow mass balance samples collected upatream and downstream from WAG 6 and tributary base flow samples will be collected on the same day. Grab samples at perimeter and interior seeps will be collected within the ensuing 24 hours.

Sediment Sampling. Bedload sediment sampling will be conducted in conjunction with surface water monitoring to gather data that will be used to determine the release of contaminants that are carried offisite with stream bed sediments. Bedload sediment samples will be collected and analyzed for specific radionuclides adhered to the sediment grains. This information will be combined with additional sediment transport mensurements or estimates of sediment mass flux to determine the contribution of contaminated . sediments to the overall surface water contaminant flux.

Bedload samplers will be utilized to collect sediment samples. Pan samplers will be used to ensure - that sediments collected and analyzed are representative of transportable sediments in the stream. These pans will be submerged in the stream near the gaged surface water monitoring site prior to forecasted storm events and will remain in the stream for the duration of the stormwater runoff event. The sediment collected in the pan will be transferred to a sample bottle and submitted for laboratory analyses.

Estimation of off-site contaminant flux in the bedload portion of sediment transport will be separated from estimation of the suspended sediment component of sediment transport. This will be accomplished by the use of bedload sediment transport models (e.g., derivations of the Einstein model), measured stream flow hydrographs, and determination of the contaminant concentrations in the bedload sediments. This methodology is probably not as precise or accurate as the methods to be used for determination of the suspended sediment flux component, however the transport of contaminated bedload sediments is most probably a very small component of total off-site flux of contamination from WAG 6.

\subsubsection{Seeps and springs}

Prior to any sampling of seeps and springs, a survey will be conducted to identify perennial seeps - and springs on the WAG 6 boundary and internal to the WAG. Seeps and springs will be monitored using base flow grab sampling techniques, as described above for surface water. An attempt will be made to measure seep and spring flow if possible. 


\subsubsection{Groundwater monitoring}

Groundwater monitoring involves two primary sampling types: water quality monitoring and water level monitoring.

Water Qunlity Monitoring. Groundwater quality monitoring will be conducted to evaluate the contribution to off-WAG risk presented by contaminated groundwater. Specific monitoring tasks are:

- groundwater sampling and analysis for selected radiologic, inorganic, and organic contaminants in the WAG 6 perimeter wells and in selected wells in the WAG interior;

- groundwater sampling and analysis for metals, anions, and field parameters at the WAG 6 perimeter wells and in selected wells in the WAG interior for geochemical monitoring; and

- groundwater sampling and analysis for periodic verification of the groundwater COCs.

The specific parameters and sampling methodology are detailed in the SAP. Groundwater sampling procedures will conform to RCRA guidance (EPA 1986) for the use of dedicated bladder pump monitoring networks. Currently approved ORNL sampling procedures will be employed. These procedures may be revised at a future time to conform with updated EPA guidance. Consideration will be given to the need to minimize purge water volumes (which may need to be handled as hazardous or radioactive waste), obtain repeatable, representative groundwater samples that are representative of in-situ groundwater conditions, and minimize the artifacts of sampling.

Water Level Monitoring. The following data collection tasks have been identified for the groundwater level monitoring task:

- Monitoring seasonal water table fluctuations.

Manual water level measurements in trench piezometers and non-trench piezometers and wells will be taken to record sessonal fluctuations in the water table and to estimate the areal extent of treach inundation via the water table.

- Monitoring transient (storm response) water level fluctuations.

Selected trench and non-trench piezometers will be instrumented with electronic pressure transducers and data loggers for continuous water level monitoring. These data will provide information regarding mechanisms by which water enters the waste disposal trenches in capped and uncapped areas. Figure 3.6 shows the conceptual hydrologic classes of trenches at WAG 6.

- Monitoring transient changes in temperature and specific conductance.

Selected locations will be instrumented for continuous monitoring of temperature and conductivity in addition to water levels. Specifically targeted are those trenches that show contimuous inundation, trenches that fluctuate with WOL stage, perimeter wells between Cap 8 and WOL, and WOL itself. These data will be used to gain an understanding of trench/groundwater/WOL interaction and will provide a qualitative estimate of groundwater flux through inundated trenches. 


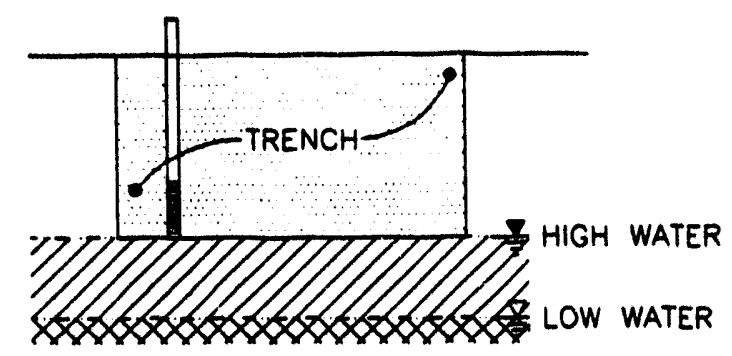

UNSATURATED:

TRENCH BOTTOM IS ABOVE

THE HIGH WATER ELEVATION AND

THERE IS NO STANDING WATER

IN TRENCH.

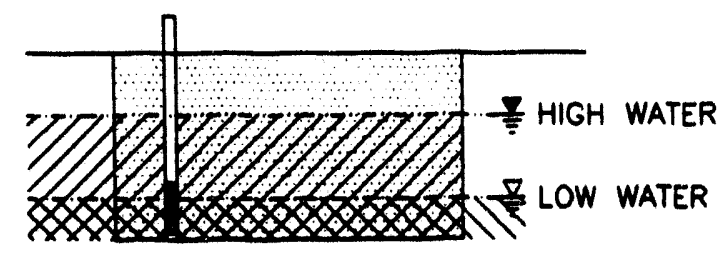

SATURATED/PERENNIALLY INUNDATED: TRENCH BOTTOM ELEVATION IS BELOW THE SEASONAL LOW WATER TABLE ELEVATION (旁).

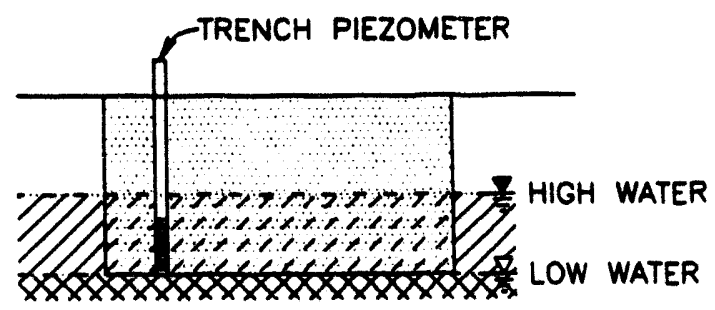

INTERMITTENTLY INUNDATED:

TRENCH BOTTOM ELEVATION FALLS

WITHIN THE RANGE OF WATER

TABLE ELEVATION.

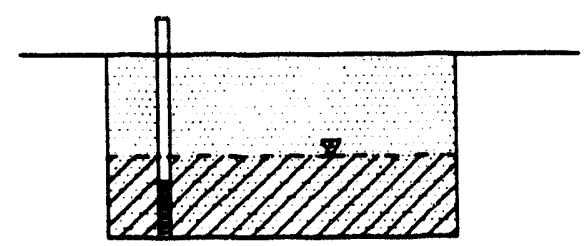

BATHTUBBING:

WATER LEVELS OBSERVED IN TRENCH WELLS (旦) AT ALL TIMES. AT ELEVATIONS GREATER THAN THE

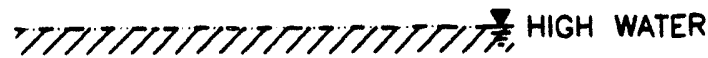
WATER TABLE ELEVATION ( $\frac{7}{\overline{3}}$ ).

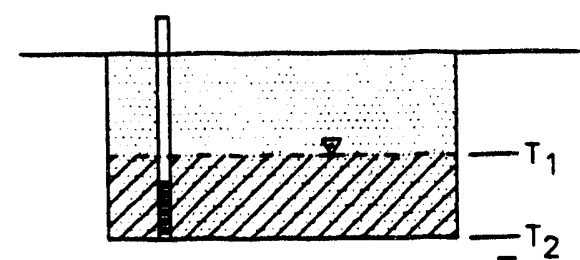

INTERMITTENT BATHTUBBING: WATER LEVELS INTERMITTENTLY OBSERVED IN TRENCH WELLS ( $\nabla$ ) AT LEVELS ABOVE THE TRUE WATER TABLE ELEVATION (

YTTTTTTITTITYTTTITE, HIGH WATER

Fig. 3.6. Hydrologic classes of trenches at WAG 6. 
For a given set of manual water level measurements, all measurements should be taken over a time period not greater than $24 \mathrm{~h}$, preferably during periods of little or no precipitation, or after wells have had time to stabilize following precipitation events. Completion of the water level survey in as short a time as practical will provide a "snapshot" in time of the water table elevation. Avoidance of storm events will ensure that the water level measurements are not unduly influenced by transient hydraulies in reaponse to the storms, because the manual measurements are directed toward representative seasonal fluctuations rather than short-term local response to storm events. The time that it takes stream hydrographs to return to base flow can be utilized to determine an appropriate stabilization time for measurements following precipitation events. Seasonal changes in the time needed for streams to return to base flow have been observed and need to be taken into account when scheduling manual water level measurements.

\subsubsection{Meteorological monitoring}

Meteorological monitoring will be conducted at WAG 6 to provide data for precipitation quantification, evapotranspiration (ET) analysis, and hydrologic response evaluation. These data are necessary for accurate water balance estimations. Details regarding the meteorological monitoring at WAG 6 are presented in the SAP. Specifically, the meteorological monitoring work plan addresses the use of meteorological parameters and frequency of measurement for the WAG 6 EMP.

The meteorological monitoring system will consist of a stand-alone 2-m tower and meteorological instruments connected to an electronic data logger for continuous data acquisition. With the exception of the precipitation gage, which will be mounted at ground level, the meteorological instrumentation will be mounted on the 2-m tower.

The following parameters will be measured at the meteorological tower:

- wind speed and wind direction,

- temperature,

- relative humidity,

- precipitation, and

- solar radiation.

\subsubsection{Analytes}

A compilation of analyte groupings for site-related COCs and potential COCs has been developed for the WAG 6 EMP. The compilation of analytes illustrated in Table 3.12 divides the analyte lists into six analyte groups. This collection of analyte groups was developed to meet the specific DQOs discussed in Sect. 2.3 and to optimize resources 80 that more money is spent tracking the greatest contributors to risk.

The first group of analytes in Table 3.12 contains only those COCs that are considered the primary comtributors to off-site risk-3 and ${ }^{-3}$. Based on analysis of previous sampling at WAG 6 (Appendix A), ${ }^{3} \mathrm{H}$ contributes nearly $92 \%$ of the 30 -year risk, followed by ${ }^{\circ} \mathrm{Sr}$ which contributes $-6 \%$ of the risk. All other potential $\mathrm{COCs}$ contribute $<2 \%$ to the 30 -year risk contributed by WAG 6 . The primary risk contributors (PRCs) grouping of analytes will be used to measure risk for the routine program under 
PO1-1 and to determine the C-Q relationship during the baseline program under PO3-2. Total suspended solids will be determined for all flow-proportional samples collected for C-Q purposes.

The second group of analytes in Table 3.12 contains all the current COCs (both major and minor contributors) that were identified in the RFI report (referred to as RFICOC). This list contains those - species of metals and volatile organies that were detected at levels above health-based concentration limits during the WAG 6 remedial investigation (RI) and man-made radionuclides that were detected at levels which exceeded the error level of the analysis. Naturally occurring radionuclides were not included in this list because their concentrations were not found to exceed comparable background concentrations. The RFICOC grouping of analytes will be used to identify potential new risk contributors at the WAG 6 boundary (PO1-2) and ideatify major contaminant sources (PO3-1) for both the routine and baseline programs.

The third group of analytes in Table 3.12 contains those analytes that are required to be measured as part of the RCRA groundwater monitoring program (RCRA). The RCRA list is also required by DOE Order 5400 . To meet the requirements of the order, several specific isotopes are reported, including ${ }^{3} \mathrm{H}$ and ${ }^{\circ 5}$, ${ }^{15} \mathrm{Cs}$, and ${ }^{\circ} \mathrm{Co}$. In addition to meeting the regulatory reporting requirements of RCRA, the information gained from these samples will be used to support the groundwater modeling studies. The RCRA grouping of analytes will be used to meet PO2-1 for both the routine and baseline programs.

The fourth group of analytes in Table 3.12 contains a wide sweep of analytes that have the potential of becoming new chemicals of concern (NCOC) at WAG 6. The NCOC list was compiled to identify those analytes that have the potential of becoming risk contributors but were not found during the 1991 RI. The NCOC grouping of analytes will be used to identify potential new risk contributors at the WAG 6 boundary (PO1-2) and identify major contaminant sources (PO3-1) for the baseline program.

The fith group of analytes are the geochemical (GC) analytes that will be used to characterize the groundwater chemistry and to assist in determining residence times and approximate flow paths. The -information contained in the GC grouping will be folded back into the groundwater OU characterization study and allow a determination of whether a particular sampling point is subject to rapid fracture recharge or is more representative of typical flows along existing flow paths. The GC grouping of analytes will be used to refine the risk estimate models (PO1-3) for the baseline program. 
Table 3.12. WAG 6 analyte groups

\begin{tabular}{|c|c|c|}
\hline Andyte group & Description & Analytes \\
\hline PRC & $\begin{array}{l}\text { site-related chemicals that contribute } \\
\text { the majority to risk and should be } \\
\text { analyzed for more frequently }\end{array}$ & ${ }^{3} \mathrm{H},{ }^{\infty} \mathrm{Sr}$ \\
\hline RFICOC & $\begin{array}{l}\text { site-related chemicals determined to be } \\
\text { COCs during RFI sample analysis (see } \\
\text { Table 1.1) }\end{array}$ & $\begin{array}{l}{ }^{3} \mathrm{H},{ }^{\infty} \mathrm{Sr} \\
\text { Gross alpha } \\
\text { Gamma scan (Cs, Co, Eu) } \\
\text { CLP volatiles (TCL) } \\
\text { CLP metals (TAL) }\end{array}$ \\
\hline RCRA & $\begin{array}{l}\text { VOCs and radionuclides required for } \\
\text { reporting under RCRA and DOE } \\
\text { Orders }\end{array}$ & $\begin{array}{l}\text { SW846 (8240) volatiles } \\
\text { alkalinity } \\
{ }^{3} \mathrm{H} ;{ }^{\circ} \mathrm{Sr} \\
\text { Gross alpha } \\
\text { Gamma scan }\left({ }^{37} \mathrm{Cs},{ }^{\infty} \mathrm{Co}, \mathrm{Eu}\right)\end{array}$ \\
\hline $\mathrm{NCOC}$ & $\begin{array}{l}\text { expanded list of analytes infrequently } \\
\text { analyzed for to confirm RFICOC list }\end{array}$ & $\begin{array}{l}{ }^{3} \mathrm{H}, \text { Sr } \\
\text { Gross alpha } \\
\text { Gamma scan } \\
\text { CLP metals, volatiles, semi- } \\
\text { volatiles, pesticides/PCBs, } \\
\text { herbicides }\end{array}$ \\
\hline GC & geochemical parameters & $\begin{array}{l}\text { ICP metals } \\
\text { anions } \\
\text { dissolved organic \& dissolved } \\
\text { inorganic carhon } \\
\text { alkalinity }\end{array}$ \\
\hline RS & radiation scans & $\begin{array}{l}\text { Gross alpha } \\
\text { Gamma scan }\end{array}$ \\
\hline
\end{tabular}

The las group of analytes is the radiological scans (RS) that will be used to help identify new radiological contaminants that may be identified in either the groundwater wells, surface water seeps, or bedload sediments. RS are a cost-effective method of identifying changes in releases or COCs. If radiation sean data indicate increased radiation levels, individual isotopes will be quantified to identify which specific nuclides are elevated. Specific analytical procedures that will be used are presented in the SAPs.

\section{SAMPLING AND ANALYSTS PLAN}

Using the sampling strategy presented in Fig. 2.3 and the locations, methods, and analytes group defined in this chapter, an SAP has been developed that covers sampling activities for the baseline and anmul routine monitoring periods. Table 3.13 summarizes these activities in relation to the program objective they address. The plan has been optimally designed to address the POs and confirm the site conceptual model outlined in Sect. 2. Sampling tasks are defined in terms of flow path groups as shown 
Tabie 3.13.' Summary of WAG 6 SAP

\begin{tabular}{|c|c|c|c|c|c|c|c|}
\hline \multirow[b]{3}{*}{$\begin{array}{l}\text { Objective } \\
\text { number }\end{array}$} & \multirow[b]{3}{*}{$\begin{array}{c}\text { Objective } \\
\text { description }\end{array}$} & \multicolumn{6}{|c|}{ Monitoring Plen Sample Requireonents } \\
\hline & & \multicolumn{2}{|l|}{ Baselino year } & \multicolumn{2}{|c|}{ Routine mounal monitorins } & \multicolumn{2}{|c|}{$\begin{array}{l}\text { Sth-Year monitoring } \\
\text { (differences from routine) }\end{array}$} \\
\hline & & Type/frequency/location & $\begin{array}{c}\text { Analyte } \\
\text { list }\end{array}$ & Type/frequency/location & $\begin{array}{c}\text { Analyte } \\
\text { list }\end{array}$ & Type/frequency/focation & $\begin{array}{c}\text { Analyte } \\
\text { list }\end{array}$ \\
\hline PO1 & Evaluate changes it & bis attributable to WAG 6 & & & & & \\
\hline PO1-1 & $\begin{array}{l}\text { Eatimale relative } \\
\text { rist at WOD }\end{array}$ & $\begin{array}{l}\text { Surface water at gaged sives - } \\
\text { MS1, MS3, MS4, WOD" } \\
\text { (monthly, } 48 \text { samples plus } \\
\text { flow datis) }\end{array}$ & $\begin{array}{l}\text { RFI } \\
\text { COCs }\end{array}$ & $\begin{array}{l}\text { Sweface water at gaged sites - } \\
\text { MS1, MS3, MS4, WOD } \\
\text { (monthly, } 48 \text { samples plus } \\
\text { flow data); } \\
\text { Overland flow at ungaged } \\
\text { sires and subsurface flow - } \\
\text { five primary perimeter seeps } \\
\text { or shallow groundwater wells } \\
\text { (semiannual, } 10 \text { samples) }\end{array}$ & 'H, ${ }^{\text {sr }}$ & & \\
\hline PO1-2 & $\begin{array}{l}\text { Verify COCs that } \\
\text { contribute majority } \\
\text { of rist }\end{array}$ & $\begin{array}{l}\text { Surface water of gaged sites- } \\
\text { MS1, MS3, MS4 (quarterly, } \\
12 \text { samples); } \\
\text { Overland flow at ungaged } \\
\text { sires and subsurface flow - } \\
5 \text { perimeter seeps, } 12 \\
\text { perimeter shallow ,7 } \\
\text { intermediate groundwater } \\
\text { wells (quarterly) and } 11 \\
\text { upgradient wells (semiannual) } \\
\text { (total } 118 \text { samples), } \\
\text { B and C sites (quarterly } \\
\text { storm grabs, } 8 \text { samples) }\end{array}$ & $\begin{array}{l}\text { Ist } \\
\text { quarter- } \\
\text { TAL } \\
\text { TCL/ } \\
\text { RFI } \\
\text { Rad; } \\
\text { 2nd-4th } \\
\text { quarter- } \\
\text { RFI } \\
\text { COCs }\end{array}$ & $\begin{array}{l}\text { Sunface water at gaged sites - } \\
\text { MS1, MS3, MS4 (semiannual, } \\
6 \text { samples); } \\
\text { Overland flow at ungaged } \\
\text { sites and subsurface flow - } \\
5 \text { primary perimeter seeps or } \\
\text { shallow groundwater wells } \\
\text { (cemiannual, } 10 \text { samples); } \\
\text { B mod C sites (semiennual, } 4 \\
\text { samples) }\end{array}$ & $\begin{array}{l}\text { RFI } \\
\text { COCs }\end{array}$ & $\begin{array}{l}\text { Surface water at gaged } \\
\text { sires - MS1, MS3, MS4 } \\
\text { (semiannual, } 6 \text { samples); } \\
\text { Overland flow at ungaged } \\
\text { sires and subsurface } \\
\text { flow - } 5 \text { primary } \\
\text { perimeter seeps or } \\
\text { shaillow groundwater } \\
\text { wells (semiannual, } 10 \\
\text { samples); } \\
\text { B and C siles } \\
\text { (semiannual, } 4 \text { samples) }\end{array}$ & $\begin{array}{l}\text { Ist semi- } \\
\text { annual } \\
\text { sample- } \\
\text { TAL/ } \\
\text { TCL/RFI } \\
\text { Red; 2nd } \\
\text { sample, } \\
\text { RFI COCs }\end{array}$ \\
\hline
\end{tabular}


Table 3.13 (continued)

\begin{tabular}{|c|c|c|c|c|c|c|c|}
\hline \multirow[b]{3}{*}{$\begin{array}{l}\text { Objective } \\
\text { number }\end{array}$} & \multirow[b]{3}{*}{$\begin{array}{l}\text { Objective } \\
\text { description }\end{array}$} & \multicolumn{6}{|c|}{ Monitoring Pien Samplo Requirements } \\
\hline & & \multicolumn{2}{|l|}{ Baseline year } & \multicolumn{2}{|c|}{ Routine smunal monitoring } & \multicolumn{2}{|c|}{$\begin{array}{l}\text { Sth-Year monitoring } \\
\text { (differesces from routine) }\end{array}$} \\
\hline & & Type/frequency/location & $\begin{array}{l}\text { Amalyte } \\
\text { list }\end{array}$ & Type/fregueacy/location & $\begin{array}{l}\text { Analyte } \\
\text { list }\end{array}$ & Type/frequency/location & $\begin{array}{c}\text { Analyte } \\
\text { list }\end{array}$ \\
\hline \multirow[t]{6}{*}{ PO1-3 } & Refine rist extimates & & & & & & \\
\hline & -Mass flux check & $\begin{array}{l}\text { Sunface water - } \\
\text { MS1, MS3, WST, WOC, } \\
\text { WOD (semiannually, } 10 \text { grab } \\
\text { samples) }\end{array}$ & ${ }^{3} \mathrm{H}, \operatorname{sos}_{\mathrm{S}}$ & $\begin{array}{l}\text { Surface water - } \\
\text { MS1, MS3, WST, WOC, } \\
\text { WOD (cemiannual, } 10 \text { grab } \\
\text { samples) }\end{array}$ & 'H, str & & \\
\hline & $\begin{array}{l}\text {-Groundwater model } \\
\text { refinement }\end{array}$ & $\begin{array}{l}\text { Subsurface flow, intermediate } \\
\text { and deep groundwater - } \\
\text { Continuous water level } \\
\text { monitoring (29 } \\
\text { wells/piesometers), water } \\
\text { level monitoring (106 } \\
\text { wells/piezometers) }\end{array}$ & & $\begin{array}{l}\text { Subsurface flow, intermediate } \\
\text { and deep groundwater - } \\
\text { Manual water level monitoring } \\
\text { (106 wells/piezometers) }\end{array}$ & & & \\
\hline & - Water Balance & $\begin{array}{l}\text { Continuous meteorological } \\
\text { data monitoring, tumulus } \\
\text { meteorology station }\end{array}$ & & $\begin{array}{l}\text { Continuous meteorological } \\
\text { data monitoring, tumulus } \\
\text { meteorology station }\end{array}$ & & & \\
\hline & $\begin{array}{l}\text { - Geochemical } \\
\text { tracking }\end{array}$ & $\begin{array}{l}\text { Subsurface flow, intermediate } \\
\text { and deep groundwater - } \\
45 \text { groundwater wells } \\
\text { (annual, } 45 \text { samples) }\end{array}$ & $\begin{array}{l}\text { Geo- } \\
\text { chemical }\end{array}$ & & & & \\
\hline & $\begin{array}{l}\text {-Identify sediment } \\
\text { transport } \\
\text { contribution to risk }\end{array}$ & $\begin{array}{l}\text { Bedlond sodiment samples, } \\
\text { MS1, MS3, MS4 } \\
\text { (seminnual, } 6 \text { samples) }\end{array}$ & $\begin{array}{l}\text { Gross } \\
\text { alpha, } \\
\text { gamma }\end{array}$ & & & & \\
\hline
\end{tabular}




\begin{tabular}{|c|c|c|c|c|c|c|c|}
\hline \multirow[b]{3}{*}{$\begin{array}{l}\text { Objective } \\
\text { number }\end{array}$} & \multirow[b]{3}{*}{$\begin{array}{c}\text { Objective } \\
\text { description }\end{array}$} & \multicolumn{6}{|c|}{ Monitoring Plan Sample Requirements } \\
\hline & & \multicolumn{2}{|l|}{ Baseline year } & \multicolumn{2}{|c|}{ Routine emmual monitoring } & \multicolumn{2}{|c|}{$\begin{array}{l}\text { Sth-Year monitoring } \\
\text { (differences from routine) }\end{array}$} \\
\hline & & Type/frequency/hocation & $\begin{array}{l}\text { Analyte } \\
\text { list }\end{array}$ & Type/frequency/location & $\begin{array}{l}\text { Analyte } \\
\text { list }\end{array}$ & Type/frequency/location & $\begin{array}{c}\text { Analyte } \\
\text { list }\end{array}$ \\
\hline PO2 & Meet regulatory re & irements & & & & & \\
\hline PO2-1 & $\begin{array}{l}\text { Moet RCRA } \\
\text { reporting } \\
\text { requirements }\end{array}$ & $\begin{array}{l}24 \text { RCRA groumdwater wells } \\
\text { (cemiannual, } 48 \text { samples) }\end{array}$ & $\begin{array}{l}\text { RCRA } \\
\text { para- } \\
\text { meters }\end{array}$ & $\begin{array}{l}24 \text { RCRA groundwater wells } \\
\text { (semiannual, } 48 \text { samples) }\end{array}$ & $\begin{array}{l}\text { RCRA } \\
\text { para- } \\
\text { meters }\end{array}$ & & \\
\hline PO2-2 & $\begin{array}{l}\text { Moet NPDES } \\
\text { reporting } \\
\text { requirements }\end{array}$ & $\begin{array}{l}\text { NPDES discharge points in } \\
\text { WAG } 6 \text { boundary are } \\
\text { associated with specific point } \\
\text { discharges (e.g., from the } \\
\text { tumulus and ICN caps) and } \\
\text { will be handled under those } \\
\text { programs }\end{array}$ & & & & & \\
\hline PO2-3 & $\begin{array}{l}\text { Comply with DOE } \\
\text { Order } 5400.5\end{array}$ & $\begin{array}{l}\text { Subsurface flow - } \\
19 \text { secondary perimeter seeps } \\
\text { or shallow groundwater wells } \\
\text { (semionnual, } 38 \text { samples) }\end{array}$ & $\begin{array}{l}\text { Groess } \\
\text { alpha, } \\
\text { gamma, } \\
{ }^{3} \mathrm{H}_{\mathrm{g}}{ }^{\mathrm{Sr}}\end{array}$ & $\begin{array}{l}\text { Subsurface flow - } \\
19 \text { secondary perimeter seeps } \\
\text { or shallow groundwater wells } \\
\text { (semiannual, } 38 \text { samples) }\end{array}$ & $\begin{array}{l}\text { Gross } \\
\text { alpha, } \\
\text { gamma, } \\
{ }^{3} \mathrm{H},{ }^{\infty} \mathrm{Sr}\end{array}$ & & \\
\hline
\end{tabular}


Table 3.13 (cominured)

\begin{tabular}{|c|c|c|c|c|c|c|c|}
\hline \multirow[b]{3}{*}{$\begin{array}{l}\text { Objective } \\
\text { number }\end{array}$} & \multirow[b]{3}{*}{$\begin{array}{l}\text { Objective } \\
\text { description }\end{array}$} & \multicolumn{6}{|c|}{ Monitoring Plen Samplo Requirements } \\
\hline & & \multicolumn{2}{|l|}{ Baseline year } & \multicolumn{2}{|c|}{ Routine ennumal monitoring } & \multicolumn{2}{|c|}{$\begin{array}{l}\text { Sth-Year monitoring } \\
\text { (differences from routine). }\end{array}$} \\
\hline & & Type/frequency/location & $\begin{array}{l}\text { Analyte } \\
\text { list }\end{array}$ & Type/frequency/location & $\begin{array}{l}\text { Analyte } \\
\text { list }\end{array}$ & Type/frequency/location & $\begin{array}{c}\text { Analyte } \\
\text { list }\end{array}$ \\
\hline $\mathbf{P O 3}$ & Support implemente & ion of interim or final setions & & & & & \\
\hline PO3-1 & $\begin{array}{l}\text { Identify major } \\
\text { sources }\end{array}$ & $\begin{array}{l}\text { Interior groundwater wells } \\
\text { (15), French drains (2), } \\
\text { internal seeps (5) (quarterly, } \\
88 \text { samples) }\end{array}$ & $\begin{array}{l}\text { Ist } \\
\text { quarter - } \\
\text { TAL } \\
\text { TCL } \\
\text { RFI } \\
\text { Rad; } \\
\text { 2nd-4th } \\
\text { quarter - } \\
\text { RFI } \\
\text { COCs }\end{array}$ & $\begin{array}{l}\text { Interior groundwater wells } \\
\text { (15), French drains (2), } \\
\text { internal seeps (5) (annual, } \\
22 \text { eamples) }\end{array}$ & $\begin{array}{l}\text { RFI } \\
\text { COCs }\end{array}$ & $\begin{array}{l}\text { Interior groundwater } \\
\text { wells (15), French drains } \\
\text { (2), seeps (5) (annual, } 22 \\
\text { samples) }\end{array}$ & $\begin{array}{l}\text { TAL } \\
\text { TCL RFI } \\
\text { Red }\end{array}$ \\
\hline \multirow[t]{2}{*}{ PO3-2 } & $\begin{array}{l}\text { Develop } \\
\text { technologies to } \\
\text { support sile } \\
\text { characterization and } \\
\text { remodiation }\end{array}$ & & & & & & \\
\hline & - Q-C Relationship & $\begin{array}{l}\text { MS1, MS3 (12 samples/year } \\
\text { during base flow, } 24 \\
\text { samples); } \\
\text { MS1, MS3 (10 samples per } 8 \\
\text { storms, } 160 \text { samples) }\end{array}$ & ${ }^{3} \mathrm{H}, \operatorname{mst}_{\mathrm{r}}$ & & & & \\
\hline
\end{tabular}


Table 3.13 (continued)

\begin{tabular}{|c|c|c|c|c|c|c|c|}
\hline \multirow[b]{3}{*}{$\begin{array}{l}\text { Objective } \\
\text { number }\end{array}$} & \multirow[b]{3}{*}{$\begin{array}{l}\text { Objective } \\
\text { description }\end{array}$} & \multicolumn{6}{|c|}{ Monitoring Plen Sample Requirements } \\
\hline & & \multicolumn{2}{|l|}{ Beseline year } & \multicolumn{2}{|c|}{ Routies ennual monitoring } & \multicolumn{2}{|c|}{$\begin{array}{l}\text { Sth-Year monitoring } \\
\text { (differences from routine) }\end{array}$} \\
\hline & & Type/frequency/location & $\begin{array}{l}\text { Analyte } \\
\text { list }\end{array}$ & Type/frequency/location & $\begin{array}{l}\text { Analyte } \\
\text { list }\end{array}$ & Type/frequency/location & $\begin{array}{l}\text { Amalyte } \\
\text { list }\end{array}$ \\
\hline & $\begin{array}{l}\text { chnology } \\
\text { nonstrations (to } \\
\text { letermined) }\end{array}$ & & & & & & \\
\hline
\end{tabular}

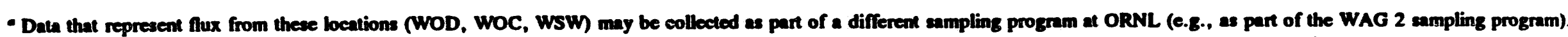

- Overland flow at ungaged sires and subsurface flow - 5 perimeter sceps, 12 perimeter shallow and 7 intermedinte groundwater wells (quarterly, 96 samples) 
in Fig. 2.1. The rationale for the proposed sampling plan is discussed below in terms of the monitoring objectives.

\subsubsection{PO1- Evaluate Changes in Risk Attributable to WAG 6}

PO1 is to identify changes in risk at the site to determine if additional action (either site characterization or remediation) is necessary. A majority of the data collected to address POI will be used to estimate flux and risk at the perimeter of WAG 6. Samples collected to refine the site hydrological model and bedload sediment sampling will be conducted as part of the baseline year monitoring activities only.

\subsubsection{PO1-1 - estimate relative risk at WOD}

Flux attributable to WAG 6 will be measured along the gaged and ungaged perimeters of the site. Samples taken at the perimeter of the waste unit and WOD will be used to estimate the relative risk at WOD. Known sampling locations are shown on Figs. 3.1 and 3.2.

Baseline Year. Surface water samples will be collected from gaged sites MS1, MS3, MS4, and WOD. The data collected at WOD provide the total flux over WOD, against which the relative contribution from WAG 6 can be estimated. Samples will be collected from these four stations monthly, for a total of 48 samples plus flow data, which is collected continuously (Sect. 3.1.2). Additionally, samples from ungaged overland and subsurface flow paths will be collected from 5 perimeter seeps, 12 perimeter shallow, and 7 perimeter water table interval groundwater wells. Samples will be collected quarterly from these 24 locations, for a total of 96 samples. Once the baseline establishes sample locations along the ungaged perimeter that can represent the ungaged flux, fewer sample locations will be necessary. Samples will be analyzed for the COCs identified in the RFI (BNI 1991) to confirm the $\mathrm{COC}$ and confirm that ${ }^{3} \mathrm{H}$ and ${ }^{\circ} \mathrm{Sr}$ are the primary risk contributors.

Boutine Annual Monitoring (Years 2-4). After baseline sampling has confirmed or contradicted the assumptions used to developed the site conceptual model, and has established a statistical baseline against which change can be measured, it is assumed that sample frequencies will decrease. The exception to the decrease in frequency is surface water samples from the gaged monitoring stations. Because it is assumed that these stations capture $\sim 85 \%$ of the total discharge from the site, they will be sampled with the same frequency as in the baseline year. Samples from ungaged overland and subsurface flow paths will be collected from five primary perimeter seeps or shallow groundwater wells (identified during baseline sampling). Sampling will be conducted semiannually, for a total of 10 samples per year. Unless the baseline identifies additional primary risk contributors, samples will be analyzed for changes in ${ }^{3} \mathrm{H}$ and osr concentrations only.

Sth-Year Monitoring. No changes from routine annual monitoring.

\subsubsection{PO1-2 - Verify COCs that contribute to majority of risk}

Occasionally it will be necessary to determine if the correct contaminants are being measured and if additional contaminants are significantly contributing to off-WAG risk. PO1-2 requires samples to be collected from the boundary of the waste unit and 11 upgradient wells to confirm the PRCs and COCs identified in the RFI and identify any other chemicals that may be contributing to risk at WOD. 
Beseline Year. Surface water samples will be collected quarterly from three gaged sites: MS1, MS3, and MS4, for a total of 12 samples. Samples from the ungaged overland and subsurface flow - paths will be collected from 5 perimeter seeps, 12 perimeter shallow, and 7 perimeter water table interval groundwater wells on a quarterly basis and 11 upgradient wells on a semiannual basis, for a total of 118 samples. Quarterly storm grab samples will be collected at the B and C sites for an additional 8 samples.

- Analyses perfon led during the first quarter of the baseline year will include TALTCL and analysis for the radiological parameters to re-establish the RFI COC list, while in subsequent quarters the analyte list will include only those identified in the RFI.

Routine Annual Monitoring. Surface water samples will be collected from gaged sites MS1, MS2, and MS4 semiannually, for a total of 6 samples. Samples will be collected from the overland and subsurface flow paths at 5 primary perimeter seeps or shallow groundwater wells and the B and C sites on a semiannual basis, for a total of 14 samples. During the routine annual monitoring, the samples will be analyzed for RFI COCs only. The primary purpose of all the analyses is to ensure that ${ }^{3} \mathrm{H}$ and ${ }^{0} \mathrm{Sr}$ remain as the only primary risk contributors.

Sth-Year Monitoring. Sample location and frequency is the same as for routine annual monitoring, but analyes performed during the first semiannual sampling event will be expanded as during the base year monitoring to include TALTTCL and the radiological parameters. Analyses for the second semiannual sampling event will be the same as for routine annual monitoring (RFICOCs).

\subsubsection{PO1-3 - Refine risk elements}

Estimating relative risk at WOD requires that $A C F$ from the site be understood. ACF is estimated using flow and water quality data from the gaged surface water stations and a combination of water - quality data and model estimates for the ungaged perimeter. PO1-3 allows for samples that will help confirm the conceptual water balance model and refine the numerical groundwater model.

Beseline Year. Samples will be collected to provide data for the following tasks: mass flux check, groundwater model refinement, water balance, geochemical tracking, and to identify sediment transport contribution to risk.

- Base flow mass flux check: surface water samples will be collected from 5 sites: MS1, MS3, WST, WOC, and WOD. These will be grab samples collected semiannually for a total of 10 grab samples. Samples will be analyzed for ${ }^{3} \mathrm{H}$ and ${ }^{\circ} \mathrm{Sr}$ only. These samples will provide a check on the base flow flux estimation methods.

- Groundwater model refinement: water level data will be obtained from the shallow, intermediate, and deep groundwater flow paths. Continuous water level monitoring will be conducted at 29 interior wells/piezometers at any given time, and manual water level monitoring will be performed at 106 wells/piezometers. These data will be used to calibrate the numerical groundwater model.

- Gechemical tracking: samples from the subsurface and intermediate and deep groundwater flow paths will be collected from $\mathbf{4 5}$ groundwater wells annually, for a total of $\mathbf{4 5}$ samples. These will be analyzed for the suite of geochemical parameters. 
- Identincation of sediment transport contribution to risk: bedload sediment samples will be collected from the gaged surface water stations MS1, MS3, and MS4 semiannually for a total of 6 amples. These samples will be analyzed for gross alpha and gamma to determine if contaminants sorbed to sediment is a transport pathway of concern at the site.

Routine Annual Monitoring. In subsequent years from the baseline year, only the mass flux check and groundwater model refinement tasks will be performed.

- Mase flux check: grab samples will be collected from the same five sites (MS1, MS3, West Seep, WOC, and WOD) and with the same frequency as in the baseline year (10 samples total). These samples will likewise be analyzed for ${ }^{3} \mathrm{H}$ and ${ }^{\circ} \mathrm{Sr}$.

- Groundwater model refinement: manual water level data will be obtained from the subsurface and intermediate and deep groundwater flow paths from 106 interior wells/piezometers.

- Water balance calculations: continuous meteorological data monitoring at the tumulus meteorology station will be collected bi-monthly to provide data on rainfall and ET for understanding the site water balance and estimating groundwater flow using the numerical model.

Sth-Year Monitoring. No changes from routine annual monitoring.

\subsubsection{PO2 - Meet Regulatory Requirements}

PO2 is to ensure that all regulatory requirements that apply to WAG 6 are addressed in the monitoring effort. These include RCRA (PO2-1); NPDES (PO2-2) and DOE Orders 5400 and $5820.2 A$ (PO2-3).

\subsubsection{PO2-1 - Med RCRA reporting requirements}

Baseline Year. Samples will be collected semiannually from 24 RCRA groundwater wells (48 samples total) and analyzed for RCRA parameters (Table 3.12).

Routine Annual Monitoring. No changes from baseline year.

Sth-Year Monitoring. No changes from routine annual monitoring.

\subsubsection{P02-2 - Meet NPDES reporting requirements}

NPDES discharge points in the WAG 6 boundary are associated with a specific point discharge at the tumulus. NPDES monitoring requirements for this discharge point will be handled under the tumulus technology demonstration monitoring plan.

\subsubsection{P03-3 - Comply with DOE Order 5400.5}

Baseline Year. Samples from the subsurface flow path will be obtained from 19 perimeter seeps or challow groundwater wells semiannually, for a total of 38 samples. These will be analyzed for ${ }^{3} \mathrm{H}$ and ${ }^{\circ 5}$ and gross alpha and gamma $\left({ }^{37} \mathrm{Cs},{ }^{\infty} \mathrm{Co}\right.$, and Eu results will be reported). 
Routine Annual Monitoring. No change from baseline year monitoring.

- Sth-Year Monitoring. No change from routine annual monitoring.

\subsubsection{PO3 - Support Implementation of Interim or Final Actions}

PO3 ensures that data are collected that will support implementation of an interim or final action at the WAG if auch an action is deemed necessary. A primary component of this objective is to understand the cource of off-WAG contaminants. The majority of the monitoring efforts described thus far will idemify if action is necessary, but will not provide the necessary information needed to identify the source of the problem.

\subsubsection{P03-1 - Identify major sources}

PO3-1 is designed to ensure that internal locations in the WAG interior near the trenches indicate changes in releases from the sources.

Baceline Year. Samples will be collected quarterly from 15 interior groundwater wells, 2 French drain outles, and 5 interior seeps, for a total of 88 samples. These samples will be analyzed during the firut quarter sumpling effiort for the TALTCL analyte list and full list of radiological parameters. In subsequent quarters, the analyte list will be RFICOCs.

Routine Annual Monitoring. Samples will be collected annually from the same sites identified above, for a total of 22 samples. The samples will be analyzed for the RFICOCs.

Sth-Year Monitoring. Samples will be collected semiannually from the sites above. During the first semiannual sampling event, the TAL/TCL and full list radiological parameters will be performed. During the second semiannual event, the samples will be analyzed for the RFICOCs.

\subsubsection{P03-2 - Develop technologies to support site characterization and remediation}

PO3-2 is concerned with developing technologies for future site characterization and remediation efforts at ORNL. The less complex methods are addressed in this plan; larger technology demonstrations will be addressed by separate plans. Also under this objective an attempt will be made to understand the C-Q relationship.

Baseline Year. Data will be obtained to define the C-Q relationship. Surface water samples will be taken from gaged stations MS1 and MS3 at the rate of 12 samples per year during base flow (24 samples) and 10 samples during 8 storm events (160 samples). These samples will be analyzed for ${ }^{3} \mathrm{H}$ and ${ }^{205}$. Sampling to be performed for technology demonstrations has not yet been determined.

Specific data will be collected to support and refine the rumeric groundwater model. In addition to using this model to calculate ACF across the ungaged perimeter, the model must be evaluated as a potential tool for evaluating post-remediation hydrologic isolation.

Routine Annual Monitoring. To be determined for technology demonstration.

Sth-Year Monitoring. To be determined for technology demonstration. 


\section{DATA ANALYSIS AND RISK ASSESSMENT}

\subsection{INTRODUCTION}

Evaluation of the data collected during the EMP will focus on addressing the POs of the plan. These POs are:

- POI - identify changes in risk associated with WAG 6,

- PO2 - med regulatory requirements, and

- PO3 - aupport Implementation of Interim or Final Actions.

This section, which is divided into two parts, presents the methods that will be used to quantitatively evaluate the data to address POI. It presents risk assessment methods that will be used to establish the bascline conditions using the baseline year data and to evaluate the data from the subsequent years to ideatify changes in relenses from the site. Section 4.4 addresses PO2 and provides specific methods for adding or deleting chemicals from the list of COCs. Some data analysis methods to support PO3-1 are presented in Sect. 4.3.3; data analysis methods for PO3-2, which addresses technology development, will be discussed in apecific plans that present selected technology demonstrations.

\section{DATA MANAGDMENT}

Sampling and field measurements will be received from the field via electronic and hard copy. Data will be electronically inserted into the WAG 6 data management system. Information in the data management system will include equipment maintenance and calibration, monitoring locations, monitoring ovent schedules, chain-of-custody forms, field measurements and samples, analytical laboratory sample transfer, tracking and results, field measurement and sample verification and validation, and data analysis. Specifics reganding the data management process for WAG 6 sampling and analysis will be described in the Data Management Plan.

The Dat Management Plan will provide organization, integrity, security, traceability, and consistency of the data generated during the WAG 6 project. Specifically, it will support the project data lifecycle including project planning, field measurements, sample tracking, laboratory analyses of enviroamental samples, data verification, validation and assessment, data consolidation and storage, transfer to the Oak Ridge Environmental Information System (OREIS), data analysis, spatial analysis and mapping, summarization and reduction of data, simulations and risk assessment calculations, data presentation, and data and document archival.

\subsection{MEIHODS TO EVALUATE CHANGES IN RISK CONDTIONS}

As indicated by the monitoring objective PO1, the ultimate use of the monitoring data will be to determine if risks posed by WAG 6 increase. Chemical concentrations and fluxes from WAG 6 will be used to esimate two types of off-WAG risk: (1) risk to a receptor at the boundary of the waste unit and, (2) the risk contribution from WAG 6 at WOD in relation to the contribution from other sources in the 
waterhed. The following section addresses the evaluation methods that will be used to address these risk concerns.

\subsubsection{Risk to the Receptor at the Boundary of the Waste Unit}

Evaluating risk to the receptor at the boundary of the waste unit is necessary (1) to establish the need for continued access controls, and (2) to provide information to regulators on the WAG-related ristes at the conventional POC.

Reeults of the RFI baseline risk assessment (see Sect. 1) indicate that risks to a hypothetical on-WAG water user would exceed acceptable risk levels. The baseline year monitoring efforts will establish the now baseline risk estimates for the hypothetical receptor located at specific points along the boundary of the WAG. It is assumed that these risk estimates will exceed the $10^{-4}$ to $10^{-6}$ acceptable risk range defined by CERCLA. The methods presented here use standard intake and risk equations from EPA (1989, 1991) and rely on toxicity data from EPA toxicity data basts [Integrated Risk Information System (IRIS) (EPA 1993) and the Health Effects Assessment Summary Tables (HEAST) (EPA 1991, 1992b)] for quantifying risks.

\subsubsection{Conceptual exposure model}

A complete exposure model includes the following components:

- an exposure point-a point in the environment where a potential receptor may directly or indirectly (e.g., via a transport pathway) contact the contamination,

- a pathway of exposure (e.8., ingestion of drinking water), and

- a potential human or environmental receptor.

The hypothetical receptor at the boundary of the waste unit may contact contaminants released from WAG 6 at an exposure point. Intake of the contaminant by the receptor is determined by the exposure point concentration, and by the exposure pathways. The details of the conceptual exposure model for WAG 6 are provided below.

Exposure Point. The exposure points that will be used to evaluate risk to the receptor at the boundary of the waste unit represent points along the boundary where each major drainage enters WOL, represented by gaged stations MS1, MS3, and MS4. These locations have been selected because it is assumed that water from all surface discharge points upstream of the monitoring stations (including above-ground seeps) flows to these monitoring points and because the surface water flow path accounts for $-85 \%$ of the water flux leaving the site. To cover the entire boundary of the waste unit, an additional exposure point will be a point along the eastern drainage of the WAG. This point covers an area where no gaged monitoring stations are located.

Exposure Point Concentrations. Generally, exposure point concentrations reflect an upper 95\% confidence level on the arithmetic mean of the data from a single monitoring station (EPA 1989). The 95\% upper confidence level (UCL) will be the standard value for risk estimates. If data appear to be lognormally distributed, the arithmetic mean of the log-transformed data will be used. This means that chemical concentrations collscted at one monitoring station throughout the year will be statistically 
evaluated to determine the $95 \%$ UCL on the arithmetic mean, and this value will be used to develop the exposure point concentration. Exposure point concentrations for MS1, MS3, and MS4 will be the UCL of the monthly concentrations from gaged flow-paced surface water sampling stations. In addition to determining the UCL, the statistical analysis of chemical data will attempt to determine the data distribution (if discernible with collected data), provide simple summary statistics of the data used to cetimate the exposure point concentration, and provide histograms for individual chemicals at individual sampling atations or for combined data sets.

Exposure Pathways. A complete exposure to a COC occurs when a receptor contacts the contaminants via an exposure route (e.g., ingestion, inhalation, etc.). For WAG 6 risk support to the environmental monitoring program, human exposure will be estimated for ingestion of drinking water. This pathway has been chosen for two reasons. First, the drinking water ingestion pathway is the pathway used by EPA to determine MCLs. Drinking water is also the default pathway recommended by EPA for developing preliminary remediation goals (EPA 1991). If it is found that VOCs have become a concern at the site, inhalation of volatiles will be considered in the risk assessment support.

Beceptor. The proposed human receptor for the risk evaluation is a potential resident who resides at the boundary of the waste unit. This person uses the surface water entering WOL as the primary source of potable water.

\subsubsection{Bisk equations and parameters for the receptor at the boundary of the waste unit}

The equations and parameters that will be used to determine cancer risk to the receptor at the boundary of the site are, for ${ }^{3} \mathrm{H}$ and ${ }^{0} \mathrm{Sr}$ :

$$
F_{\partial}\left(E P C_{\text {waOd }}\right)\left(I_{\text {w }}\right)(E F)(E D) \text {, }
$$

where

$$
\begin{aligned}
& \text { Risk = ectimated cancer risk associated with releases from WAG } 6 \text { (unitless probability), } \\
& \text { SF. } \quad=\text { oral cancer slope factor (chemical-specific, risk/pCi), } \\
& \mathrm{EPC}_{\text {waos }}=\text { exposure point concentration at boundary of WAG } 6(\mathrm{pCi} / \mathrm{L}) \text {, } \\
& \mathrm{R}_{\text {w }}=\text { water ingestion rate }(2 \mathrm{~L} / \text { day), } \\
& \text { EF } \quad=\text { exposure frequency (350 days/year), } \\
& \text { ED }=\text { exposure duration ( } 30 \text { years). }
\end{aligned}
$$

If it is found that nonradioactive chemicals become primary risk contributors the equation fo: evaluating chemical carcinogens is:

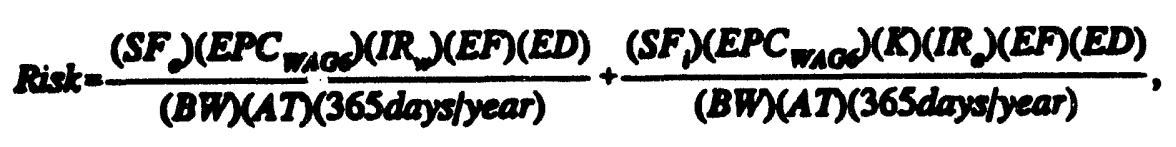

.where 


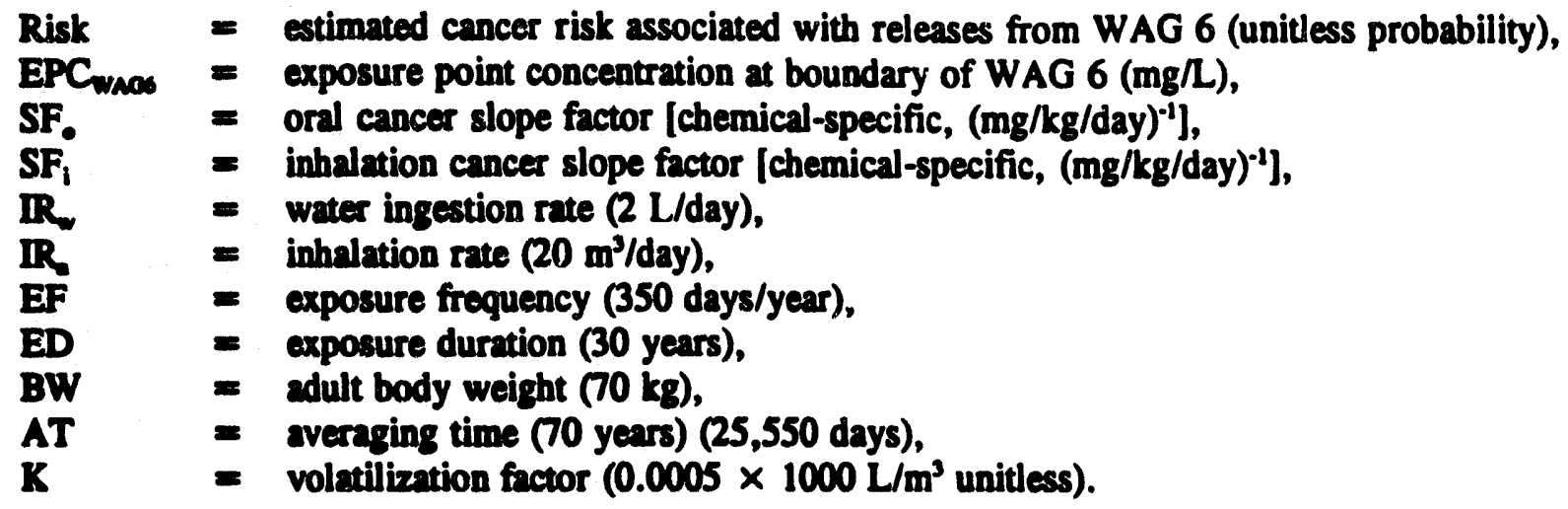

The second expression in the equation is only necessary for evaluating VOCs. Most of the values in the equation are default values from EPA 1991.

The equation for chemical toxicants is:

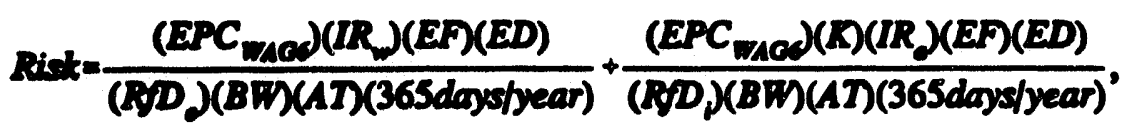

where

RfD $_{0}=$ oral reference dose [chemical-specific, (mg/kg/day)],

$\mathbf{R F D}_{\mathrm{i}} \quad=$ inhalation reference dose [chemical-specific, $(\mathrm{mg} / \mathrm{kg} /$ day $)$ ].

As with chemical carcinogens, the second expression in the equation is only necessary for evaluating vOCs.

\subsection{Relative Risk from WAG 6 at WOD}

To quantify how the releases from WAG 6 compare to releases from other sources in the WOL watershed, it is necessary to understand the risk associated with total contaminant flux released from WAG 6.

Contaminant flux is the movement of mass past a measuring location or across a boundary per unit time, and thus is measured in mass per unit time. Annual contaminant flux is calculated by:

[contaminant concentration in water $(\mathrm{mg} / \mathrm{L})] \times$ water volume $(\mathrm{L} / \mathrm{year})$ = contaminant mass flux (mg/year).

For the WAG data evaluation effort, the period of time is 1 year. ACF will be reported in units of Curies for radioactivity and in units of kilograms for metals and organics. 
The ultimate use of the flux calculation is to compare the WAG 6 flux to the total contaminant flux released over WOD. This analysis provides an estimate of the relative risk at WOD in relation to the other WAGs which in turn provides important information for prioritizing response actions for the different sources. If there is a trend towards an increase in the relative risk then the deferred action decision can be reevaluated. The first year of monitoring (baseline monitoring) is designed to generate - the initial catimates of contaminant flux and relative risk levels.

\subsection{Dedermining water balance}

To quantify ACF, it is necessary to understand the flux contributed by each of the four flow path groups ideatified in Fig. 2.1. This can be done through the formulation of a complete water balance of the WAG that defines the amount of water discharged through each flow path. This information can be andyzed, along with contaminant concentration data gathered from exposure points in each pathway, to eatimate the contaminant flux for each constituent. Once the fluxes are known, the relative risk for each comaminant, as well as the cumulative risk for all contaminants leaving the WAG, can be estimated.

There are five basic components of water balance for WAG 6: the change in water storage (AS), precipitation (P), evapotranspiration losses (ET), surface water flow (SW), and groundwater flow (GW). The water balance for WAG 6 is summarized in the following equation:

$$
\Delta S=P-E T-S W-G W \text {. }
$$

$\Delta S$ represents an estimate of the overall change in total mass of water stored in the WAG 6 system. Generally, $\Delta S$ is relatively small and consists mainly of long-term (i.e., yearly) changes of water storage in the groundwater system.

The depth of rain, measured from a gage located within WAG 6, will be aerially distributed over the WAG and will serve as the P component of the water balance. There are other rain gages located - in the vicinity of WAG 6 that will be used to supplement the rainfall data and determine the uniformity of rainfall across the WAG.

The last three components of water balance represent the major contaminant transport pathways of the WAG. The SW component accounts for the total contaminant flux of surface water leaving WAG through gaged sites and ungaged areas. The GW component accounts for flow from the WAG through the shallow, intermediate, and deep groundwater contaminant transport pathways. Finally, the ET component describes the combined losses of available water from the WAG through evaporation and transpiration processes. Ench of these components must be measured and/or predicted from the information gathered as part of the EMP.

Table 4.1 summarizes the various methods that will be used to quantify all three of the transport pathway components of the water balance. This table presents a tiered approach to flux quantification, with the first tier being the method most likely to be used for contaminant release monitoring. As more information and understanding of the system are gained, additional tools, presented in the other tiers, may be used. The following is a brief discussion of the transport pathway component approaches. 
Table 4.1. Tiered approach for transport pathway component quantification

\begin{tabular}{|c|c|c|c|}
\hline $\begin{array}{l}\text { Traneport } \\
\text { componeat }\end{array}$ & $\begin{array}{l}\text { Tier } 1 \\
\text { epproach }\end{array}$ & $\begin{array}{c}\text { Tier } 2 \\
\text { approach }\end{array}$ & $\begin{array}{c}\text { Tier } 3 \\
\text { approach }\end{array}$ \\
\hline sw & $\begin{array}{l}\text { direct menaurements and area- } \\
\text { weighted empirical eetimnies }\end{array}$ & atatistical flow predictors & $\begin{array}{l}\text { calibrated } \\
\text { models }\end{array}$ \\
\hline GW & water balance modal & groundwater model & $\begin{array}{l}\text { groundwater } \\
\text { model } \\
\text { refinements } \\
\text { and expansions }\end{array}$ \\
\hline ET & $E T=P-S W-G W$ & ET predictor equations & none \\
\hline
\end{tabular}

Surface Water Flow. The first tier approach for determining WAG 6 contaminant flux from surface water is to simply integrate the measured flows collected at the gaged stations throughout the year and cotimate the flows in ungaged areas using empirical tools. Flow at ungaged sites will be estimated by area-based adjustments to flow data measured at gaged sites and the water balance model. After baseline monitoring is completed, if contaminant flux is determined to be significant then predictive tools such as watershed models (e.g., HEC1) may be used to estimate ungaged runoff.

Groundwater Flow. The first tier approach for estimating groundwater flow volume is the use of the simple water balance equation for the ORNL site (Moore 1988; Solomon et al., 1992). This model provides an estimate of the total water volume flowing through the shallow subsurface flow path, based on total rainfall and loss via surface runoff and evapotranspiration. The use of the water balance approach will not provide groundwater volume flowing across specific boundaries of the site. To obtain this information, a second tier method must be used. The second tier method for the estimation of groundwater flow is the use of a 3-D groundwater flow model of WAG 6 (e.g., Ebasco Environmental 1993). Currently, both large-scale and small-scale three-dimensional (3-D) saturated groundwater models exist for the WAG 6 region. The small-scale WAG 6 model incorporates greater detail, utilizing a finer grid, and the large-scale Melton Valley model incorporates the impact of regional flow on the local flow system at the WAG by including the deep flow system. Additionally, two-dimensional (2-D) transient models have been developed for selected cross sections within the WAG, and a 2-D transient saturated/unsaturated model incorporating storm flow is under development.

The third tier approach for groundwater volume estimates requires the refinement and expansion of the existing groundwater models. Comparison of large- and small-scale 3-D model design and output will provide information to guide the establishment of boundary conditions appropriate for model support of the WAG 6 environmental monitoring objectives. Development and calibration of saturated/unsaturated steady-state flow models and of saturated transient flow models will be the primary vehicle for improving boundary flux estimates and for testing and revising the conceptual hydrologic model for WAG 6.

Tasks that may be performed to help refine flux estimates for the ungaged perimeter include:

- compare boundary conditions and water balances from the large-scale and small-scale models,

- perform sensitivity analysis to determine the relative importance of input parameters (field observations) and to quantify the uncertainty in the model output (boundary fluxes), 
- update the model calibration as stream discharge and water level data become available,

- develop and calibrate a 2-D saturated/unsaturated transient model that incorporates storm flow and the impact of trenches, and will provide a means for testing the relative importance of the storm flow and shallow groundwater systems, and

- develop and calibrate a 3-D saturated transient model.

In addition to providing a tool for estimating flux, the modeling efforts will also provide a tool for engineering design and measuring the effects of remedial alternatives.

Evapotranspiration. The first tier approach for the estimation of ET simply requires the quantification of the water within WAG 6 that is not taken into account by the surface water and groundwater flows. Under a first tier approach ET will be calculated using the following equation:

$$
E T=P-S W-G W .
$$

A problem with use of this equation arises due to errors in measuring the precipitation, and the surface water and groundwater terms. These errors will be reflected in the ET term. Therefore, to check the rensonableness of the ET term calculated by the first tier approach and to better understand the ET process itself, ET will also be estimated using the mathematical method reported by Van Bavel and Hillel (1976) or empirical equations that calculate evaporation, such as the Penman equation (Bedient and Huber 1989). As additional data are gathered during implementation of the EMP, second tier estimations of ET can be refined so that the results are more indicative of the ET process occurring at WAG 6.

\section{-4.32.2 Estimating relative nux}

To provide the total risk from WAG 6 for comparison to risk from other WAGs, it is necessary to develop a cumulative risk estimate that reflects the risk from the total flux. Theoretically, this cumulative risk represents a risk to a receptor that drinks from each source in proportion to its total flow. Although the scenario is unreal, these assumptions make it possible to estimate relative risk from a flux (mg/year) instead of from a concentration (mg/L). This approach views the exposure point as a point at the end of the "funnel" described in Fig. 2.1 where all contaminants from all flow paths drain.

As water-borne contaminants from WAG 6 move into WOL they merge with the instream contaminants. To determine the relative contribution to risk observed at WOD, the main measuring point before WOL empties into the Clinch River, ACF for ${ }^{3} \mathrm{H}$ and ${ }^{00} \mathrm{Sr}$ for WAG 6 is computed as follows:

$$
A C F=\left(C_{s p}\right)\left(V_{s g}\right)+\left(C_{s}\right)\left(V_{s}\right)+\left(C_{s}\right)\left(V_{s}\right)+\left(C_{s}\right)\left(V_{s}\right)
$$

where

$A C F=$ annual contaminant flux for ${ }^{3} \mathrm{H}$ and ${ }^{00 \mathrm{Sr}}$,

C = flow-proportional average discharge concentration from flow paths (sg, su, ss, gw),

$\mathrm{V}=$ discharge volume for flow paths [surface water gaged (sg), surface water ungaged, (su), subsurface flow (ss) and groundwater (gw)]. 
The average concentration for gaged surface water $C_{\alpha}$ is :

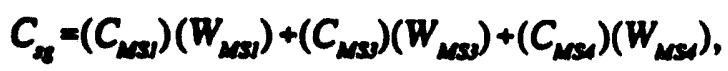

where

$\mathrm{C}_{\operatorname{man}}=$ the flow-weighted mean contaminant concentration for surface water (at MS1, MS3, and MS4),

$\mathbf{W}_{\operatorname{ma}} \quad$ = the weight for surface water at MS1 which is directly proportional to the volume for the monitoring station and can be calculated using the following equation:

$$
W_{\text {MSI }}=\frac{V_{\text {Mas }}}{V_{\text {SWO }}}
$$

where

$V_{\operatorname{ma1}}=$ the total volume of water discharged via surface water at each gaged monitoring station,

$V_{\text {swo }}=$ the total annual volume of water discharged from all gaged surface water stations.

Concentrations using the sample results generated at a single gaged station are weighted based on flows. Samples collected from the automatic samplers at these stations on a monthly basis will be averaged using flow-weighting principals to come up with the annual average concentration.

Average contanainant concentrations for ungaged surface water, the subsurface flow path, and the intermediate and deep groundwater will be estimated by averaging the concentrations detected at the various perimeter sampling locations. Average flow volumes and flow path weights for these flow paths will be estimated using the site water balance model and the groundwater model.

The relative contribution (RC) of each contaminant is computed by solving equation (4-4) for both WAG 6 discharges and those measured at WOD:

$$
R C=\frac{A C F_{\text {mad }}}{A C F_{\text {mod }}}
$$

where

$\mathbf{R C}=$ relative contribution from WAG 6,
$\mathbf{A C F}_{\text {was }}=$ annual contaminant flux released from WAG 6,
$\mathbf{A C F}_{\text {wod }}=$ annual contaminant flux released from WOD. 


\subsubsection{Estimating relative risk to the off-property receptor from WAG 6}

In order to estimate a total risk from all pathways for a given chemical, it is necessary to determine an average concentration from all flow paths. This can be done using the following equation:

$$
C_{\text {max }}=\left(C_{\infty}\right)\left(W_{\infty}\right)+\left(C_{m}\right)\left(W_{m}\right)+\left(C_{\infty}\right)\left(W_{\infty}\right)+\left(C_{s m}\right)\left(W_{\infty w}\right)
$$

where

C is calculated using equation 4-5 for the surface water gaged flow path and using average concentrations for other flow paths. $W$ is calculated using the weighting principal presented in equation 4-6. $V$ for each flow path is calculated using measured volumes for surface water gaged and the water balance model for the other flow paths.

Risk associated with ${ }^{3} \mathrm{H}$ and ${ }^{0} \mathrm{Sr}$ is estimated by calculating $\mathrm{C}_{\text {waO }}$ and using equations $4-1$ through 4-3. The resulting risk estimates for ${ }^{3} \mathrm{H}$ and ${ }^{0} \mathrm{Sr}$ can be summed to come up with total risk associated with WAG 6 (Risk waod.

Likewise, the relative contribution of WAG 6 to the risk observed a WOD is computed as:

$$
\frac{\left(R I S K_{\text {mas }}\right)\left(V_{\text {mas }}\right)}{\left(R S K_{\text {mod }}\right)\left(V_{\text {mod }}\right)}
$$

- where $V$ is the total volume of water flowing from WAG 6 and WOD.

Relative risk will be measured using the same pathways and exposure parameters as those used for the receptor at the boundary of the waste unit.

\subsubsection{Contaminant Trend Analysis}

Trend analysis will be an important part of the data evaluation. Trend analysis methods have been designed to address PO1 and PO3-1 of the program by posing several specific questions.

First, are contaminant concentrations and associated risks at the boundary of the waste unit increasing or decreasing over time? This question can be answered by a statistical comparison of the results of the routine annual data to the results of the baseline data. Various methods may be used to track trends, including parametric and nonparametric comparisons of means, and/or the use of regression analysis of concentretion trends over time.

Second, are contaminant fluxes from WAG 6 increasing or decreasing over time, resulting in:

- a change in the total flux over WOD 
- a change in the relative flux contribution from WAG 6 to the total contaminant flux leaving the watershed over WOD?

Because of the complexity of calculating a total flux from the site, it is expected that values will change from year to year based on several factors unrelated to changes in the actual conditions at the site, e.g., the site conceptual model will be refined, resulting in changes in the data evaluation procedures used to calculate flux. When this happens, data from the baseline year will need to be reevaluated using the updated methods to make year-to-year comparisons.

Third, is an observed change in ACF a function of a greater volume of water flowing through the unit (e.g., increased annual rainfall) or a function of increased releases from the sources?

This question will be answered by monitoring interior groundwater wells and by establishing the C-Q relationship at the site. Data from internal wells will be evaluated using trend analysis techniques. The C-Q relationship characterizes the change in surface water concentration over a range of surface water discharge measurements by using both base flow and storm sampling data. Defining the $C-Q$ relationship with data for the baseline year can provide the information necessary to understand flux from year to year despite changes in the volume of rainfall that passes through the WAG. The samples and methods for defining the C-Q relationship are discussed in Sect. 3 and presented in detail in Appendix C.

\subsection{METHODS TO IDENTIFY CHANGES IN COCs}

An important aspect of the EMP is its ability to identify changes in COCs at the site to ensure that the chemicals being analyzed are the primary contributors to risk. COCs for the site were initially identified during the RFI (BNI 1991). From the initial list, primary COCs were determined to be those that were detected at levels above regulatory concern, using MCLs and health-based levels as the criteria for placing a chemical on the final list. However, the COCs at WAG 6 may change over time. Previously unidentified contaminants may be detected due to degradation of containers or other physical changes in the waste disposal trenches. This section describes how additional COCs will be identified in the future and how current COCs may be deleted from the existing COC list. All additions to or deletions from the $\mathrm{COC}$ list will be restricted to the appropriate media or location.

New COCs will be identified by conducting expanded analyses for the CERCLA TAL/TCL list in combination with analyses for gross alpha emitting radionuclides and gamma spectroscopy. The combination of these analyses will provide for detection of all contaminants that are known, or suspected to have been disposed of, at WAG 6. The expanded analysis program will be conducted once during the baseline monitoring phase and during the fifth year of the routine annual monitoring phase (projected to be FY 1998). Expanded analysis will be performed on groundwater at all groundwater quality wells and surface water samples at all gaged surface water monitoring points. Detection of new COCs in surface water may trigger evaluation of the need to monitor for new COCs in stream sediments. Stream sediments will be monitored for changes in COCs, following detection of new COCs in surface water, if the new COCs are strongly sorbed $\left(K_{d} \geq\right.$ about $\left.10 \mathrm{~mL} / \mathrm{g}\right)$ or if the baseline monitoring phase has determined that off-WAG sediment transport contributes $>5 \%$ of the contaminant flux at the WAG perimeter. 
Figure 4.1 presents the general decision tree for identifying new COCs. Site-specific background concentrations will be established during baseline monitoring and using historical data. $\mathrm{MCL}$ and healthbased action-levels used in the decision process are provided in Appendix $D$. The following section provides details of the process.

\subsubsection{Inorganic and Organic Contaminants}

Following quantifiable detection of new inorganic or organic chemical(s) in a location or media, the concentration of the detected chemical will be compar $d$ to background concentrations and health-based criteria such as Safe Drinking Water Act (SDWA) MCLs and action levels. If the detected level of the chemical exceeds the health-based criteria, confirmation sampling will be performed within 3 months. If the confirmation sampling confirms that the chemical exceeds the screening criteria, the chemical will be added to the COC list for that particular media or location.

\subsubsection{Radionuclides}

For previously undetected fission products, detectable by gamma spectroscopy, a radionuclide will be a candidate for the COC list if its detected analytical concentration in both an initial and a confirmation sampling round exceeds three times the standard deviation of the counting error.

MCLs for gross alpha will be used to determine if a newly detected radionuclide should be added to the list. If the gross alpha level exceeds $5 \mathrm{pCi} / \mathrm{L}$ confirmation sampling will be required. If the confirmation sample also exceeds $5 \mathrm{pCi} / \mathrm{L}$ gross alpha, alpha spectroscopy will be sonducted on an aliquot of the confirmation sample to determine the contributing radionuclide. The detected alpha emitting radionuclide(s) will be added to the COC list if they are not naturally occurring (i.e., U, Th, Ra).

${ }^{3} \mathrm{H}$ and ${ }^{0 S} \mathrm{Sr}$ are not COCs at all sampling locations. Periodic checks will confirm or contradict this. If the level of ${ }^{3} \mathrm{H}$ exceeds $20,000 \mathrm{pCi} / \mathrm{L}$ or ${ }^{95}$ exceeds $8 \mathrm{pCi} / \mathrm{L}$ that radionuclide will be added to the - COClist at that location. As for other contaminants, confirmation sampling rounds for radionuclides will be conducted within 3 months of the initial detection.

\subsubsection{Methods for Identifying COCs to be Deleted from the List}

If a contaminant contained in the current $C O C$ list is not detected in a specific media or at a specific location, at a concentration exceeding a health-based concentration for four consecutive sampling rounds, the contaminant will be removed from the COC list. Removal of the contaminant from the COC list does not preciude sampling and analysis for that parameter for directed studies, or use of the contaminant concentrations in risk analysis. Removal of a contaminant from the $\mathrm{COC}$ list removes the contaminant from consideration for routine annual sampling and analysis. These contaminants will continue to be analyzed for during the expanded sampling. 


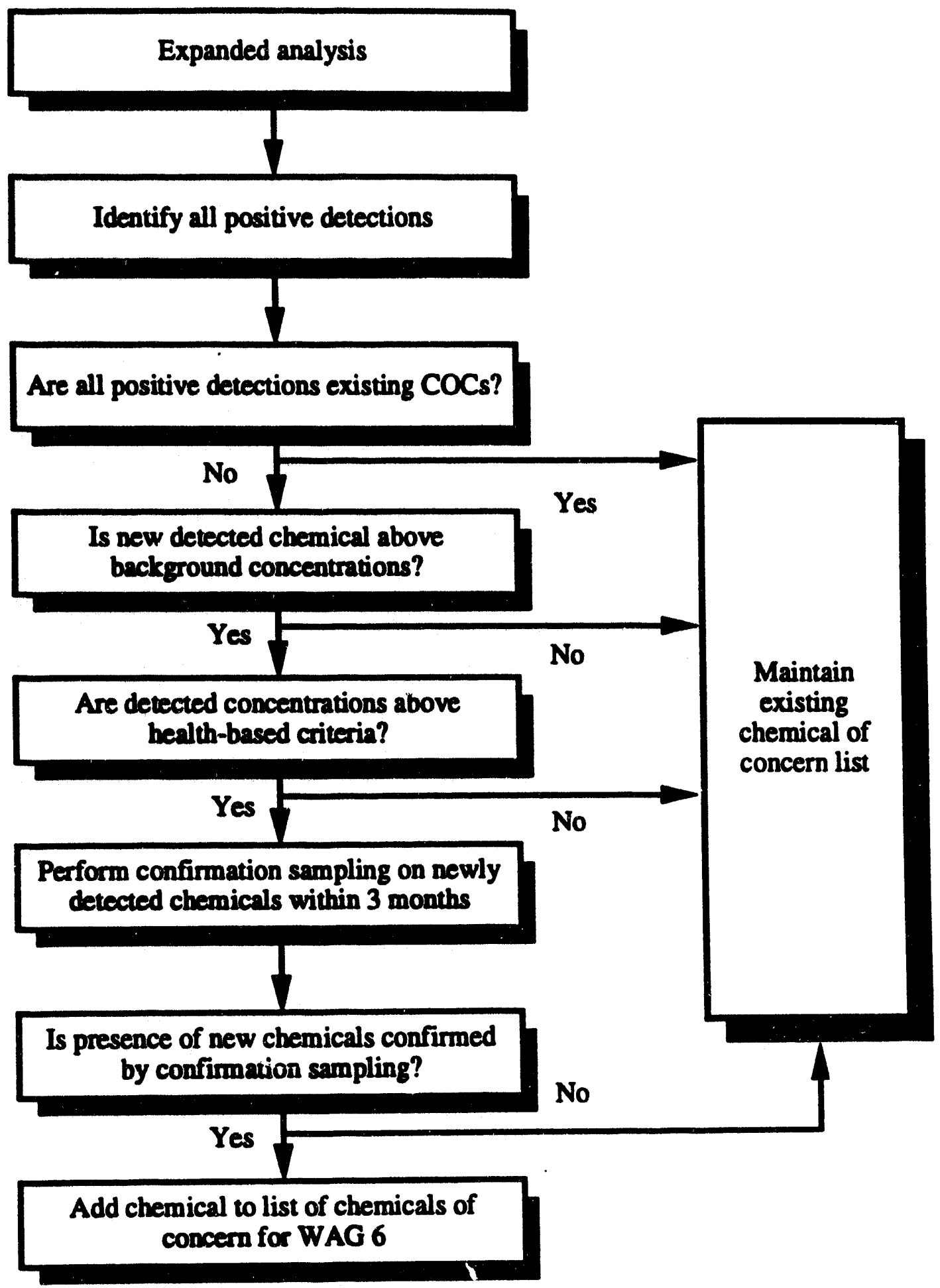

Fig 4.1. Decision tree. 


\section{PROGRAM STRATEGY AND ADMINISTRATION}

\section{S.1 GENTRRAL}

The WAG 6 EMP is divided into three components as indicated in Fig. 2.4: baseline monitoring, routine annual monitoring, and 5th-year monitoring. Proposed monitoring activities and schedules are presented for each specific monitoring task in the monitoring task portion of the document. Baseline monitoring will begin in the fall 1993. It will end once 12 months worth of data has been collected from the now gaged monitoring atations. The baseline characterization phase is intended to confirm the site conceptual model, eatablish a statistical basis against which change will be measured, confirm that ${ }^{3} \mathrm{H}$ and Sr are primary risk contributors, $c$ nfirm the RFI COC list, meet regulatory requirements, and begin demonstration of the Q-C relationship. This phase is estimated to take 12-18 months to complete.

The routine annual monitoring will begin at the completion of the baseline monitoring phase. Routine monitoring is intended to identify changes in risk associated with WAG 6, confirm that ${ }^{3} \mathrm{H}$ and Sr continue to be the primary contributors to risk, and to meet regulatory requirements.

During the Sth-year monitoring, an expanded analyte list will be evaluated to confirm the RFI COC list as part of meeting the overall objectives of the monitoring program.

\subsection{PROJECT DOCUMENT ROAD MAP}

The EMP is intended to serve as a strategy document for deferred action environmentul monitoring - at the WAG 6 site. It is in response to a Memorandum of Understanding between DOE, EPA, and TDEC, concerning future activities for WAG 6. Figure 5.1 shows the relationship between the Memorandum of Understanding, the EMP, and the supplemental documents that support the plan. These

- supplemental documents provide additional details on implementing the plan and include a QAPjP, the QAPjP for the environmental monitoring program that expands on the Quality Assurance Plan (QAP) for WAG 6, a site Health and Safety Plan, a Data Management Plan, a Site Mobilization Plan, and the SAPs.

\subsection{REPORTING SCHIDDURE}

A Baseline Characterization Report will be prepared that documents baseline environmental conditions. The Baseline Characterization Report will be submitted to the regulatory community 9 months after completion of the baseline monitoring phase (Table 5.1).

At the end of 1 year of routine annual monitoring, an Annual Monitoring Report (AMR) will be prepared. This report will be submitted to the regulatory community 9 months after the first year of routine annual monitoring (Table 5.1). AMRs will be prepared and submitted annually. This annual reporting will continue until directed otherwise through an agreement between DOE and the regulatory community. 


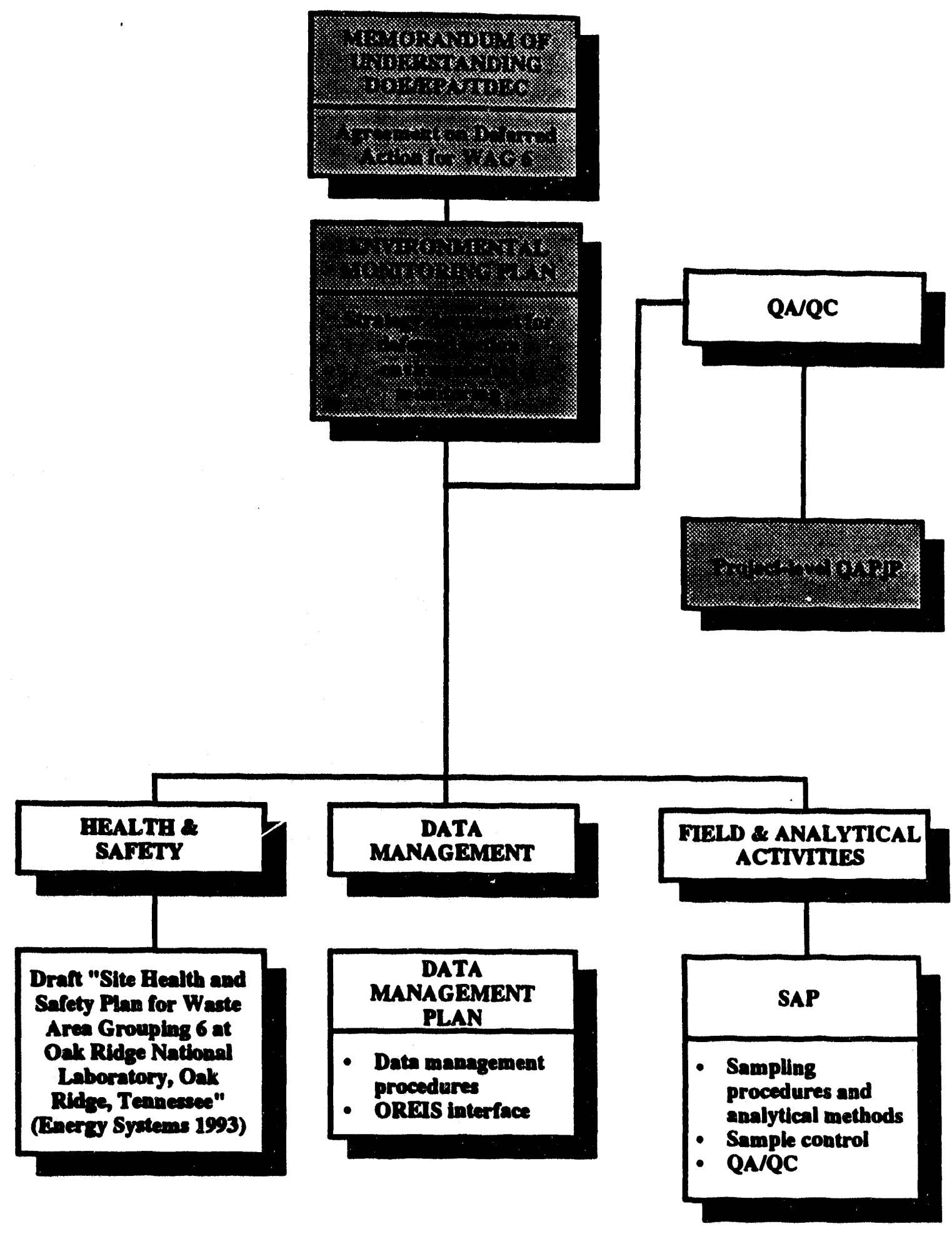

- Documents requiring DOE/EPA/TDEC approval

Fig. 5.1. Document roadmap. 
Table 5.1. Reporting schedule

- Report type

Baseline Chancterization Report

Annual Monitoring Report
Report issued to regulatory agency

9 months after routine snnual monitoring started

9 moaths after each 12-month routine annual monitoring period is completed

\subsection{DURATION}

The EMP will be evaluated at the end of each year of monitoring to determine if the program is meeting stated goals. At the end of 5 years of monitoring, the program will be subject to a performance review. The EMP described in this document will be terminated in conjunction with the 5-year performance review, or at the end of the 5th-year monitoring. Any monitoring after that point will be addressed by a separate program. 


\section{REFERENCES}

Bedient, P. B. and W. C. Huber 1989. Hydrology and Floodplain Analysis. Addison-Wesley Publishing Company, New York.

BNI (Bechtel National, Inc.) 1991. RCRA Facillity Investigation Report for Waste Area Grouping 6 at Oak Ridge National Laboratory, Oak Ridge, Tennessee, IRA 1910930.2015 , ES/ER-22/V1\&D1, ORNL/ER/SUB-87/99053/5/V1.

Clapp, R.B., and D.S. Marshall 1992. SWSA 6 Interim Corrective Measures Environmental Monitoring:FY 1991 Results. ORNL/ER-87.

Ebasco Environmental 1993. WAG 6 Interim Remediation Design Criteria Studies: Results of 3D and 2D Groundwater Flow Modeling (available from Ebasco Environmental, Oak Ridge, TN).

EPA (U. S. Environmental Protection Agency) 1986. RCRA Ground-Water Monitoring Technical Enforcement Guidance Document (TECD). Office of Emergency and Remedial Response and Office of Waste Programs Enforcement, Washington, D.C. OSWER Directive 9950.1, September.

EPA 1989. Risk Assessment Guidance for Superfund: Human Health Evaluation Manual, Part A, Interim Final, EPA/540/1-89/002, Office of Emergency and Remedial Response.

EPA 1991. Risk Assessment Guidance for Superfund: Human Health Evaluation Manual, Part B, Development of Risk-Based Preliminary Remediation Goals, Interim. Office of Emergency and Remedial Reaponse, Publication 9285.7-01B.

EPA 1992a. RCRA Ground-Water Monitoring: Draft Technical Guidance. Office of Solid Waste, Washington, D.C. EPA 530/R-93/001, November.

EPA 1992b. Health Effects Assessment Summary Tables, FY-1992 and Supplements 1 and 2. Office of Emergency and Remedial Response, OERR.6-303(92).

EPA 1993. Integrated Risk Information System (IRIS) on-line computer database, EPA, Washington, D.C.

Garten, C.T., Jr., and R.D. Lomax 1987. Strontium-90 Contamination in Vegetation from Radioactive Waste Seepage Areas at ORNL and Theoretical Calculations of ${ }^{\circ} \mathrm{Sr}$ Accumulation by Deer, Oak Ridge National Laboratory, ORNL/TM-10453.

Loar, J.M. (ed.) 1988. Second Annual Report on the ORNL Biological Monitoring and Abatement Program, Oak Ridge National Laboratory, Draft ORNL/TM Report.

Moore, G.K. 1988. Concepts of Groundwater Occurrence and Flow Near Oak Ridge National Laboratory, Tennessee. O2: Ridge National Laboratory, ORNL/TM-10969.

.Moore, G.K., and L.E. Toran 1992. Supplement to a Hydrologic Framework for the Oak Ridge Reservation ORNLIMM-12191, Oak Ridge, Tennessee.

93-0T2Prososiss 
6-2

Solomon, D.K., G.K. Moore, L.E. Toran, R.B. Dreier, and W.M. McMaster, 1992. Status Report, A Hydrologic Framework for the Oak Ridge Reservation, ORNL/TM-12026, Oak Ridge, Tennessee.

Van Bavel, C.M.H., and D.I. Hillel 1976. Calculating Potential and Actual Evaporation From a Bare Soll Surface by Simulation of Concurrent Flow of Water and Heat. Agricultural Meteorology, V. 17 pp. 453-476, 1976. 


\section{GLOSSARY OF TERMS}

annuai contaminant fux - water volume (L/yr) $\times$ average contaminant concentration $(\mathrm{mg} / \mathrm{L})$ from each of the primary flow paths (e.g., surface water) at the site.

"aquiclude - low permeability unit forming either the upper or lower boundary of a groundwater flow unit. Occurs 590-790 ft below ground surface on the ORR and contains saline water. The aquiclude is considered to be the lower boundary of groundwater flow on the ORR.

base now - normal, or non-storm induced surface water flow contributed by discharge from groundwater seeping into stream. Base flow may vary seasonally.

baseline monitoring - monitoring conducted to confirm the findings of the RFI with respect to off-site transport of COCs; establishes baseline flux and risk estimates to which routine annual monitoring results can be compared; provides input into directed study activities; and obtains information to assist in refining the EMP for the routine annual sampling phase. The baseline monitoring will last 12-18 months.

chemical of concern (COC) - for the EMP, COCs are defined as compounds that have been detected above background and above MCLs.

C-Q relationship - the relationship between volumetric flow rate $(Q)$ and concentrations $(C)$ used to evaluate change in contaminant flux that is related to changes in rainfall. If steady state conditions are assumed, Q-C can be used to predict contaminant concentrations by measuring flow.

deep groundwater interval - characterized by slow fracture flow with significantly lower number of fractures than overlying intermediate groundwater zone. Waters within this zone typically contain greater dissolved solids than in the overlying zones, and are generally of the sodium bicarbonate type. Chloride content increases as the aquiclude is approached.

downgradient wells - wells on the WAG perimeter characterized on the basis of location down hydraulic gradient or along geologic strike of waste dispor a areas, used to estimate the flux of groundwater contamination through the ungaged shallow perimeter and intermediate to deep groundwater system.

evapotranspiration (ET) - that portion of precipitation returned to the air through evaporation from open bodies of water and soil surfaces, and transpiration from the soil by plants.

excess lifetime cancer risk - the probability that an individual will develop cancer as a result of exposure to the carcinogen(s) being evaluated.

exposure pathways - means by which a potential receptor comes in contact with the contamination (e.g., ingestion of drinking water)

exposure point - a point in the environment where a potential receptor may directly or indirectly (e.g., via a transport pathway) contact the contamination.

exposure point concentration - concentrations of contaminants at the exposure point, reflecting an upper 95\% confidence level (95\% UCL) on the arithmetic mean of the data from a single monitoring station.

now volume - volume of water flowing in a stream or through an aquifer past a specific point in a given period of time.

now path - pathways identified by which water leaves the WAG. Four major flow paths have been identified for WAG 6: surface water flow that can be measured at gaged sites; overland flow at ungaged sites; subsurface flow paths (includes storm tıw zone and water table interval groundwater); and intermediate and deep groundwater.

fux - mass of contaminants across a boundary per unit time.

fracture zone - the portion of the subsurface bedrock which is characterized by numerous fractures through which groundwater flows. 
gaged monitoring station - monitoring stations located on the perimeter of the WAG so as to provide the most useful data for determining total off-WAG flux. The gaged monitoring stations are equipped with hydraulic structures and electronic data logging and auto sampling equipment. Approximately $85 \%$ of surface water from the WAG passes through gaged stations MS1, MS3, and MS4. Data collected from the gaged stations will allow calculation of contaminant flux from the WAG during both base flow and storm flow conditions.

harard index (HII) - ratio of estimated intake of chemical toxicants over the acceptable intake. If the ratio is $>1$, there may be a concern for public health effects.

hydraulic conductivity - the capacity of a porous rock, sediment, or soil for transmitting a fluid; it is a measurement of the relative ease of fluid flow under unequal pressure. Geologic formations with lower hydraulic conductivity are less permeable, or more resistant to flow; those with higher hydraulic conductivity are more permeable, or less resistant to flow.

hydraulic gradient - the rate of change of total hydraulic head (water level) per unit of distance of flow at a given point and in a given direction.

interior well - wells within the WAG perimeter chosen to provide adequate spatial distribution for assessing WAG-wide changes in releases from the waste sources.

intermediate groundwater interval - ranges in thickness from 100-330 $\mathrm{ft}$ and is characterized by a transition from mixed-cation bicarbonate waters to sodium bicarbonate waters. Hydraulic conductivity within this zone is lower than in the overlying water table interval. The majority of the water mass is contained in the matrix porosity while the majority of flow occurs in the fractures. Most groundwater in this interval flows very slowly to surface discharge points with a very small percentage flowing toward the deep groundwater zone.

matrix diffusion - process by which compounds dissolved in water move through rock matrix from areas of higher concentration to areas of lower concentration.

a.t-site - outside the physical boundary of ORNL.

off-WAG - outside the physical boundary of WAG 6. Applies especially to WOD, which is the destination of most off-WAG contaminant flux.

on-site - within the physical boundary of ORNL

on-WAG - within the physical boundaries of WAG 6.

PARCC - analytical parameters of precision, accuracy, repeatability, completeness, and comparability. perched water zones - unconfined groundwater separated from the underlying main body of groundwater by unsaturated rock or soil.

piezometer - non-pumping well consisting of a tube or pipe open at both ends which is used to measure the elevation of the water table or potentiometric surface in field situations.

primary risk contributors (PRC) - those constituents contributing to the majority of risk at the site boundary and at WOD - e.g., ${ }^{3} \mathrm{H}$ and ${ }^{10} \mathrm{Sr}$.

receptor - potential human or ecological recipient of exposure to risk.

routine annual monitoring - monitoring conducted after the baseline year which consists of continued sampling and analysis to provide the information necessary to calculate annual changes in contamination releases and risk associated with WAG 6. This phase will continue for 5 years.

seeps and springs - represent the continuum between surface water and groundwater systems. Seeps and springs are the points at which subsurface water discharges to the surface water system and thus mark the predominant groundwater discharge points.

site conceptual model - a model that describes the physical parameters and risk estimates known about the current conditions at a site.

site hydrogeological model - a model that describes physical parameters such as water flow and water balance at the site. The key aspects of the WAG 6 site hydrologic model are given in Sect. 1.3.3.1. 
site access controls - physical barriers (fencing, warning signs, patrols, and institutional controls) to prevent public exposure to on-site contaminants.

source control remedial measures - engineering actions taken at the source point that result in a significant reduction of risk or contaminant flux.

storm now zone - zone extending from ground surface to a depth of 3-7 ft. Nearly all subsurface water

- in undisturbed areas flows through the storm flow zone via large pores. Lateral flow in the zone is caused by the large $(1000 \times$ greater $)$ hydraulic conductivity through the pores. Subsurface water flowing in this zone is either quickly discharged to surface seeps and springs and surface water drainages, lost via evapotranspiration, or held as soil moisture. A small percentage of water flowing through the storm flow zone percolates through the vadose zone toward the water table interval.

storm flow - surface water flow associated with storm events.

transport pathway - path by which contaminants are transported from the source to a potential receptor site.

trench - disposal trenches within the WAG. Water level data will be collected in trench piezometers to record long-term changes in trench water levels, and to provide information about short-term fluctuations of water levels. Five hydrologic classes of trenches have been identified at WAG 6, see Fig. 3.6 for explanation.

ungaged monitoring locations - monitoring locations along the perimeter of the WAG where no gaged station exists.

upgradient well - wells located on the WAG perimeter that have been characterized as uncontaminated and representative of upgradient water quality.

vadose zone - a groundwater zone that extends from the base of the storm flow zone to the top of the water table, and exists throughout WAG 6 except where the water table intersects the land surface. The thickness of the vadose zone is dependent upon seasonal and precipitation-induced water table fluctuations. It is typically thicker under ridges than in valleys. Recharge through the vadose zone is controlled by rainfall and occurs through discrete permeable zones.

water balance - hydrologic budget equation used to examine the relationship between precipitation (P), evapotranspiration (ET), runoff (R) and infiltration (I).

- water table interval - the continuously saturated zone below the vadose zone, characterized by calcium bicarbonate water chemistry. This zone transmits most of the water that reaches this depth to surface water via seep and spring discharge points. The bulk of the mass of water in this interval resides in the matrix porosity, however, the majority of flow occurs in fractures. The water that is not transmitted along this interval to the surface moves downward through a series of dipping, imbricate fracture zones towards the intermediate groundwater interval.

watershed - drainage basin, or area that diverts all runoff to the same drainage outlet.

weir - a device placed across a stream that measures the discharge as water flows over a specially designed spillway. 


\section{APPENDIX A}

\section{PRELIMINARY CALCULATION OF RELATIVE}

RISK AT WHITE OAK DAM 


\section{CONTENTS}

TABLES $\ldots \ldots \ldots \ldots \ldots \ldots \ldots \ldots \ldots \ldots \ldots \ldots \ldots \ldots \ldots \ldots \ldots$ A-v

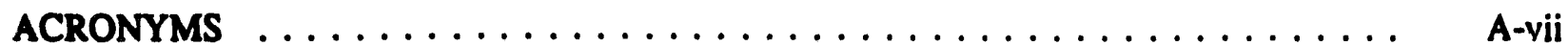

- A. PRELIMINARY CALCULATION OF RELATIVE RISK AT

WHITE OAK DAM $\ldots \ldots \ldots \ldots \ldots \ldots \ldots \ldots \ldots \ldots \ldots$ A-1

A.1 DATA FOR RISK ESTIMATE $\ldots \ldots \ldots \ldots \ldots \ldots \ldots \ldots \ldots$ A-1

A.1.1 Surface Water $\ldots \ldots \ldots \ldots \ldots \ldots \ldots \ldots \ldots \ldots$ A-1

A.1.2 Shallow Subsurface Flow Paths . . . . . . . . . . . . . A-3

A.1.3 Intermediate and Deep Groundwater Flow Path ............ A-3

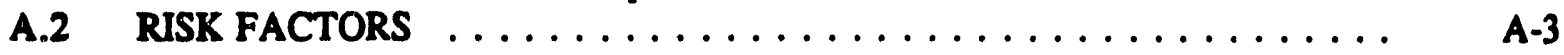

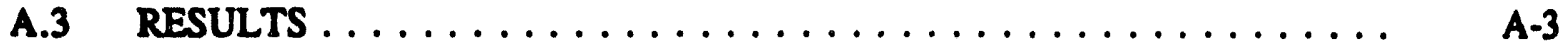

REFERENCES $\quad \ldots \ldots \ldots \ldots \ldots \ldots \ldots \ldots \ldots \ldots \ldots \ldots \ldots \ldots$ A-10

93-072P1090993 A-iii 


\section{TABLES}

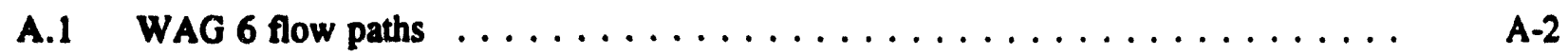

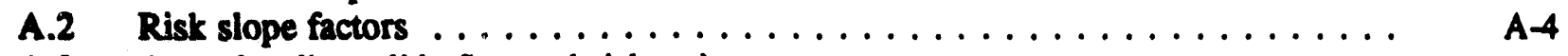

A.: Annual radionuclide flux and risk estimates

for WAG $6,1992 \ldots \ldots \ldots \ldots \ldots \ldots \ldots \ldots \ldots \ldots \ldots \ldots \ldots$ A.5

A.4 Annual chemical flux and risk estimates

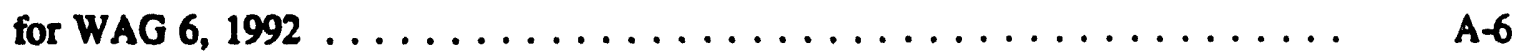

A.5 Risk summary for WAG 61992 based on available data . . . . . . . . . . . . A A-7

A.6 Comparison of risk at WAG 6 perimeter and WOD . . . . . . . . . . . . A-9 


\section{ACRONYMS}

ACF annual contaminant flux

C concentration

- COC chemicals of concern

C-Q concentration-discharge relationship

EMP Environmental Monitoring Plan

ICM Interim Corrective Measures

Q Discharge

RF risk factors

RSF risk slope factors

SSFP subsurface flow path

WAG Waste Area Grouping

WOC White Oak Creek

WOD White Oak Dam 


\section{PRELIMINARY CALCULATION OF RELATIVE RISK AT WHITE OAK DAM}

Calculation of risk is a primary goal of the Waste Area Grouping (WAG) 6 Environmental - Monitoring Plan (EMP). This section describes the basic approach to calculating risk that will be used in the annual report of the EMP, although it is expected that equations will be updated and that parameter values will be revised as new data become available.

The values of mean concentration for contaminants and contaminant fluxes reported herein represent the best approximations to date, however there are numerous sources of uncertainty, some quantifiable and some unquantifiable at this time. The treatment of uncertainties is cursory here because the available data are sparse, especially for certain flow paths along parts of the WAG perimeter.

The chemicals of concern (COCs) are fission-product radionuclides and volatile organic compounds. Although alpha-emitting radionuclides and heavy metals have been measured at elevated levels in various locations, none was considered to be important to off-WAG risk.

The methodology for calculating risk values is described in Sect. 4 of the EMP. The goal is to determine 30-year decay-adjusted risk based on the assumption that the contaminant concentrations of all water exiting the WAG site are flow-proportionately averaged.

\section{A.1 DATA FOR RISK ESTIMATE}

The WAG was subdivided into hydrologic flow paths as shown in Table A.1. Data were collected or estimated and then averaged for each COC (index $i$ ) and each flow path (index $j$ ). For each flow path the total volume of water discharged during the year was also estimated. At monitoring sites where flow- averaging was not possible simple averaging was used. Non-detects were treated as zero concentrations.

\section{A.1.1 Surface Water}

Discharge (Q) was measured at four small flumes March 1992 - February 1993 as part of Interim Corrective Measures (ICM) environmental monitoring. $Q$ at FA often bypassed the flume, therefore total $\mathbf{Q}$ for this site was estimated on a per-area basis using $Q$ from FB. Base flow grab samples and automatic storm samples were collected and analyzed for fission-product radionuclides over the period March 1992 through August 1992. As described in Appendix C, the discharge-concentration (C-Q) relationships were derived, and total annual contaminant flux (ACF) and flow-weighted mean concentration (C) were computed for ${ }^{3} \mathrm{H}$ for drainages $\mathrm{FB}, \mathrm{DA}$, and $\mathrm{DB}$, and for ${ }^{9} \mathrm{Sr}$ for $\mathrm{FB}$. The ${ }^{0} \mathrm{Sr}$ was not found in significant quantities in the other drainages. Cesium-137 was detected in a few samples at all sites, and simple averages of all data (including nondetects) were used. Organic chemicals were measured during base flow conditions at each drainage during 1989 (BNI 1991). Because the tributaries were often dry, only $2-4$ samples were collected per site. These data were averaged and adjusted to reflect flow during - base flow conditions using only a base flow factor derived from the $C-Q$ analysis in Appendix $C$. 
Table A.1. WAG 6 flow paths

\begin{tabular}{|c|c|c|c|c|c|c|}
\hline Location & $\mathbf{j}$ & $\begin{array}{l}\text { Fowpath } \\
\text { group }\end{array}$ & $\begin{array}{l}\text { Drainage } \\
\text { area } \\
(\mathrm{m} 2)\end{array}$ & $\begin{array}{l}\text { Cument } \\
\text { seep } \\
\text { sites }\end{array}$ & $\begin{array}{c}\text { Groundwater } \\
\text { wells }\end{array}$ & $\begin{array}{l}\text { New } \\
\text { Groundwater } \\
\text { wells }\end{array}$ \\
\hline DA & 1 & swo & $4.090+04$ & & & \\
\hline DB & 2 & SWG & $3.64 e+04$ & & & \\
\hline $\mathbf{F A}$ & 3 & swo & $3.72 e+04$ & & & \\
\hline FB & 4 & swg & $7.65 e+04$ & & & \\
\hline MS4-future & 5 & swU & $3.03 e+04$ & & & \\
\hline B & 6 & SWU & $1.15 e+04$ & & & \\
\hline C & 7 & SWU & $5.76 e+03$ & & & \\
\hline SSFP1 & 8 & SSW & $1.87 e+04$ & & 865,833 & \\
\hline SSFP2 & 9 & ssw & $3.57 e+04$ & & $835,836,836$ & NWQ-1 \\
\hline SSFP3 & 10 & ssw & $1.35 e+04$ & & 838 & \\
\hline SSFP4 & 11 & Ssw & $1.96 e+04$ & SW6-1 & $840,842,1243$ & NWQ-3, NWQ-5 \\
\hline SSFPS & 12 & ssw & $1.73 e+04$ & SW6-2 & 843,1242 & \\
\hline WAG-GW & 13 & DGW & $2.75 e+05$ & & $\begin{array}{c}745,839,841, \\
844,860 \\
\end{array}$ & NWQ-2, NWQ-4, NWQ-6 \\
\hline
\end{tabular}


At MS4 and for drainages B and C the concentrations of all contaminants in surface water r unoff were assumed to be negligible. These sites are known to be contaminated, but contamination is reflected in the seep concentrations of the subsurface flow paths.

\section{A.1.2 Shallow Subsurface Flow Paths}

Average concentrations for the water table interval were derived from quarterly surveillance sampling of shallow wells on the perimeter July 1988 - December 1992. Seep SW6-1 in subsurface flow path (SSFP) 5 was sampled twice (March and September 1992) and seep SW6-2 in SSFP4 was sampled once (September 1992) for radionuclides. For the other SSFPs it was assumed that the storm flow water was negligible and a single zero-concentration hypothetical spring observation was inserted in the data. This assumption seems reasonable because concentrations in nearby groundwater are relatively low.

\section{A.1.3 Intermediate and Deep Groundwater Flow Path}

The deep groundwater system is conceptualized as a single flow path. The upgradient recharge area was estimated as the WAG area itself ( $47 \mathrm{ha}$ ) although in fuire risk analyses the contributing area will be determined by groundwater model simulations. The average concentrations were computed from results of the quarterly surveillance sampling.

\section{A.2 RISK FACTORS}

The calculations were made in a spreadsheet model termed WAGRISK. The model requires risk slope factors (RSF), which were used to derive risk factors (RF) for 1-year ingestion of water, 30-year jngestion of water, and 30-year ingestion with radioactive decay, as shown in Table A.2. Five organic compounds were reported at levels of concern:

\begin{tabular}{|c|c|c|}
\hline $\begin{array}{l}\text { Trichloroethene } \\
\text { Tetrachloroethene } \\
\text { 1,2 Dichloroethene } \\
\text { 1,2 Dichloroethane } \\
\text { Carbon tetrachloride }\end{array}$ & $\begin{array}{l}\text { TCE } \\
\text { TCETE (or PEC) } \\
1,2 D C E \\
1,2 D C A \\
\text { CCL4 }\end{array}$ & $\begin{array}{l}\text { noncarcinogen } \\
\text { noncarcinogen } \\
\text { noncarcinogen } \\
\text { carcinogen } \\
\text { carcinogen }\end{array}$ \\
\hline
\end{tabular}

Data on all of the organic compounds are included in the spreadsheet model and there is provision for a sixth compound (listed as OTHER), however only carcinogenic risk was computed.

Table A.2 shows the risk slope factors, and the simple risk factors for 1-year, 30-year, and 30-year with radioactive decay. Risk factors for the noncarcinogenic organics are zero.

\section{A.3 RESULTS}

Mean Concentration $\bar{C}_{i j}$ for each contaminant and flow path is shown for radionuclides in Table A.3 and for organics in Table A.4. These tables also show the annual contaminant flux and 1-year risk for each flow path. Total fluxes are shown in Curies for radionuclides and grams for organic chemicals. The total risk for the site is not the sum of the risk levels in Tables A.3 and A.4 because they have to be flow-weighted. Total risk values are shown in Table A.5. 


\section{A-4}

Table A.2. Risk slope factors

Radionuclides

\begin{tabular}{|c|c|c|c|c|c|}
\hline Contaminant & $\begin{array}{c}\text { Bnlf-life } \\
(y)\end{array}$ & $\begin{array}{c}\mathrm{RSF} \\
(1 / \mathrm{pCi} / \mathrm{L})\end{array}$ & $\begin{array}{c}\text { 1-year } \\
\text { RF } \\
\text { (1/pCi/L) }\end{array}$ & $\begin{array}{c}\text { 30-year } \\
\text { RF } \\
\text { (1/pCi/L) }\end{array}$ & $\begin{array}{c}\text { 30-year } \\
\text { RF } \\
\text { w/decay } \\
\text { (1/pCi/L) }\end{array}$ \\
\hline${ }^{3} \mathbf{H}$ & 12.6 & $5.40-14$ & $2.7 e-11$ & $8.10-10$ & $3.970-10$ \\
\hline$\omega_{S r}$ & 29 & $3.60-11$ & $1.80-08$ & $5.40-07$ & $3.850-07$ \\
\hline${ }^{137} \mathrm{Cs}_{3}$ & 30.17 & $2.80-11$ & $1.40-08$ & $4.20-07$ & $3.040-07$ \\
\hline${ }^{\infty} C_{0}$ & 5.27 & $1.50-11$ & $7.5 e-09$ & $2.25 e-07$ & $5.59 e-08$ \\
\hline
\end{tabular}

\begin{tabular}{ccc}
\multicolumn{3}{c}{ Organics } \\
\hline Contaminant & $\begin{array}{c}1 \text {-year } \\
\text { RF } \\
(1 \mu g / L)\end{array}$ & $\begin{array}{c}30 \text {-year } \\
\text { RF } \\
(1 / \mu g / L)\end{array}$ \\
\hline TCE & 0 & 0 \\
TECETE & 0 & 0 \\
$1,2 D C A$ & 0 & 0 \\
$1,2 D C E$ & $8.70-08$ & $2.60-06$ \\
CCl4 & $1.20-07$ & $3.7 e-06$ \\
Other & 0 & 0 \\
\hline
\end{tabular}


Table A.3. Anneal rediopnctide fox and rist extimates for WAG 6, 1992

-Recharge Rates-

\begin{tabular}{|c|c|c|c|c|c|c|c|c|c|c|c|c|c|c|}
\hline \multirow[t]{2}{*}{ Fom pala } & \multirow[t]{2}{*}{ j } & \multirow[t]{2}{*}{ Fon } & \multirow{2}{*}{$\begin{array}{l}\text { Drimene } \\
\text { (n) }\end{array}$} & \multirow{2}{*}{$\begin{array}{l}\text { Shom } \\
\text { nom } \\
(\infty y)\end{array}$} & \multirow{2}{*}{ 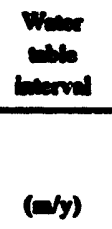 } & \multirow{2}{*}{ 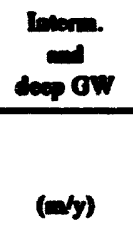 } & \multirow{2}{*}{ 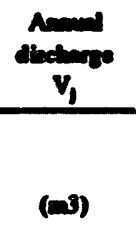 } & \multirow{2}{*}{$\frac{\mathrm{Mm}}{\mathrm{HB}}$} & \multicolumn{2}{|c|}{$\begin{array}{c}\text { Constiven } \\
\text { E. }\end{array}$} & \multicolumn{3}{|c|}{ 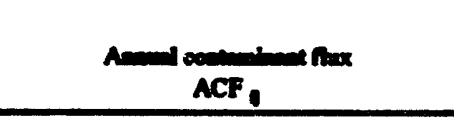 } & \multirow{2}{*}{ 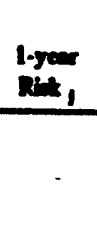 } \\
\hline & & & & & & & & & $\begin{array}{l}\sin 0 \\
(\mathrm{con})\end{array}$ & $\begin{array}{l}\text { Co137 } \\
\text { (C) } M 1)\end{array}$ & $\begin{array}{l}\text { H3 } \\
\text { (C) }\end{array}$ & $\begin{array}{l}3 \times 0 \\
(C) i\end{array}$ & $\begin{array}{l}\text { Cot37 } \\
\text { (CD) }\end{array}$ & \\
\hline DA & 1 & swo & $4.09 e+04$ & & & & $3.00+04$ & $7.50+\infty 6$ & & $1.7 e+\infty$ & $2.3 e+01$ & 0.0 & 5.20005 & 2.0000 \\
\hline DB & 2 & swo & $3.64 e+04$ & & & & $1.4 e+04$ & $1.20+05$ & & I.1e+01 & $2.6 e+\infty 0$ & 0.0 & $1.60-04$ & $5.00-06$ \\
\hline FA & 3 & swo & $3.72 e+04$ & & & & $1.20+04$ & $2.00+05$ & & 3.20002 & $2.4 c+\infty 0$ & 0.0 & $4.60-07$ & $5.40-06$ \\
\hline $\mathbf{F B}$ & 4 & swo & $7.65 e+04$ & & & & $2.58+04$ & $1.9 e+\infty$ & $2.3 e+02$ & $2.3 e+\infty 0$ & $4.7 e+01$ & $5.60-03$ & $5.60-05$ & $5.50-05$ \\
\hline MSA & 7 & swo & $3.03 e+04$ & & & & $8.1 e+03$ & $7.00+05$ & & & $5.7 e+\infty$ & 0.0 & 0.0 & 1.90005 \\
\hline B & s & swe & $1.15 e+04$ & & & & $2.8 e+03$ & 0.0 & & & 0.0 & 0.0 & 0.0 & 0.0 \\
\hline c & 6 & swo & $5.76 e+03$ & & & & $1.4 e+03$ & 0.0 & & & 0.0 & 0.0 & 0.0 & 0.0 \\
\hline S5FP1 & 8 & $5 s w$ & $1.87 e+04$ & 0.52 & 0.05 & & l.leten & $1.0 e+02$ & & & $1.10-03$ & 0.0 & 0.0 & $2.80-09$ \\
\hline SSFP2 & 9 & ssw & $3.57 e+04$ & 0.52 & 0.05 & & $2.0 e+04$ & $2.2 e+03$ & & & 4.40 .02 & 0.0 & 0.0 & 5.90 .08 \\
\hline SSFP3 & 10 & ssw & $1.35 \mathrm{se}+04$ & 0.52 & 0.05 & & $7.7 e+03$ & $1.70-02$ & & & $1.30-02$ & 0.0 & 0.0 & $4.60-00$ \\
\hline SSFP4 & 11 & ssw & $1.960+04$ & 0.52 & 0.05 & & 1.1etan & $1.4 e+05$ & & & $1.6 e+00$ & 0.0 & 0.0 & 3.9006 \\
\hline SSFPS & 12 & ssw & $1.73 e+04$ & 0.52 & 0.05 & & $9.9 e+03$ & $9.0 e+05$ & & & $8.9 x+\infty$ & 0.0 & 0.0 & 2.40 .05 \\
\hline WAO-OW & 13 & DGW & $2.75 e+05$ & & & 0.005 & $1.40+03$ & $3.4 c+04$ & & & $4.70-02$ & 0.0 & 0.0 & $9.30-07$ \\
\hline TOTAL & & & & & & & $1.5 e+0 s$ & & & & $9.1 e+01$ & $5.60-03$ & 2.7004 & \\
\hline
\end{tabular}

93-072P1081993 
Table A.4. Anneal chemical flux and rist extimates for WAG 6, 1992

\begin{tabular}{|c|c|c|c|c|c|c|c|c|c|c|c|c|c|c|c|c|}
\hline Fow & 1 & $\begin{array}{l}\text { Shord } \\
\text { now } \\
2000\end{array}$ & |liser & Desp & 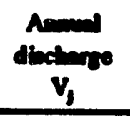 & & Mon & $\begin{array}{l}\text { Conomant } \\
\mathbf{c}_{1}\end{array}$ & & & An & ACF, & $100 x$ & & & $\begin{array}{c}\text { 1.yen } \\
\text { Ris., } \\
\end{array}$ \\
\hline & & & & & & TCE & TCETE & $1,2 \mathrm{DCA}$ & $1,2 \mathrm{DCE}$ & CCN & TCE & TCETE & $1,20 \mathrm{CA}$ & $1,2 \mathrm{DCE}$ & ccn & \\
\hline & & $\left(\omega_{y}\right)$ & $(m / y)$ & $(\omega y)$ & (m) & $(m / 2)$ & $(\omega / n)$ & $(m / 1)$ & $(0 / / 4)$ & $(m / n)$ & (b) & (b) & (D) & (c) & (a) & \\
\hline DA & 1 & & & & $3.0 x+04$ & $1.30-01$ & 0.0 & 0.0 & 0.0 & 0.0 & $4.0 e+\infty 0$ & 0.0 & 0.0 & 0.0 & 0.0 & 0.0 \\
\hline Do & 2 & & & & $1.4 e+04$ & 0.0 & 0.0 & 0.0 & 0.0 & 0.0 & 0.0 & 0.0 & 0.0 & 0.0 & 0.0 & 0.0 \\
\hline $\mathbf{F A}$ & 3 & & & & $1.2 e+04$ & 0.0 & 0.0 & 0.0 & 0.0 & 0.0 & 0.0 & 0.0 & 0.0 & 0.0 & 0.0 & 0.0 \\
\hline F & 4 & & & & $2.5 e+04$ & 2.40 .01 & $1.60-01$ & 0.0 & $8.70-01$ & 0.0 & $5.9 e+\infty$ & $4.4 e+\infty 0$ & 0.0 & $2.1 e+01$ & 0.0 & 7.5000 \\
\hline Mast & 7 & & & & $8.1 e+03$ & 0.0 & 0.0 & 0.0 & 0.0 & 0.0 & 0.0 & 0.0 & 0.0 & 0.0 & 0.0 & 0.0 \\
\hline B & 5 & & & & $2.2 e+03$ & 0.0 & 0.0 & 0.0 & 0.0 & 0.0 & 0.0 & 0.0 & 0.0 & 0.0 & 0.0 & 0.0 \\
\hline c & 6 & & & & $1.4 e+03$ & 0.0 & 0.0 & 0.0 & 0.0 & 0.0 & 0.0 & 0.0 & 0.0 & 0.0 & 0.0 & 0.0 \\
\hline SSFP1 & 8 & 0.52 & 0.05 & & $1.1 e+04$ & 0.0 & 0.0 & 0.0 & 0.0 & 0.0 & 0.0 & 0.0 & 0.0 & 0.0 & 0.0 & 0.0 \\
\hline SSFP2 & 9 & 0.52 & 0.05 & & $2.0 x+04$ & 0.0 & 0.0 & 0.0 & 0.0 & $7.50-06$ & 0.0 & 0.0 & 0.0 & 0.0 & $1.5 e-04$ & $9.2 e-13$ \\
\hline S5FP3 & 10 & 0.52 & 0.05 & & $7.7 e+03$ & 0.0 & 0.0 & 0.0 & 0.0 & 0.0 & 0.0 & 0.0 & 0.0 & 0.0 & 0.0 & 0.0 \\
\hline SSFP4 & 11 & 0.52 & 0.05 & & 1.1e+on & $2.3 e+01$ & $1.90-01$ & $1.3 e+\infty$ & $6.30-01$ & $\begin{array}{c}4.1 e+0 \\
0\end{array}$ & $2.5 e+02$ & $2.1 e+\infty 0$ & $\begin{array}{c}1.4 e+0 \\
1\end{array}$ & $7.1 e+\infty 0$ & $\begin{array}{c}4.6 e+0 \\
1\end{array}$ & $5.7 e-07$ \\
\hline S5FPS & 12 & 0.52 & 0.05 & & $9.9 e+03$ & 0.0 & 0.0 & 0.0 & $3.6 e-01$ & 0.0 & 0.0 & 0.0 & 0.0 & $3.6 e+\infty 0$ & 0.0 & $3.1 e-08$ \\
\hline WAO-OW & 13 & & & 0.005 & $1.4 e+03$ & $1.2 e+\infty$ & $2.40-01$ & 0.0 & 0.4 . & 0 & $1.6 e+\infty 0$ & $3.30-01$ & 0.0 & $5.50-01$ & 0.0 & $3.5 e-08$ \\
\hline TOTAL & & & & & $1.5 e+05$ & & & & & & $2.7 e+02$ & $6.80+\infty 0$ & $\begin{array}{c}1.4 e+0 \\
1\end{array}$ & $3.3 e+01$ & $\begin{array}{c}4.6 e+0 \\
1\end{array}$ & \\
\hline
\end{tabular}

93-072P1081993 
Table A.5. Risk summary for WAG 61992 besed on svailable data

Annusi contaminent flux

$\mathbf{A F C}_{1}$

Redionuclide

Chemicals

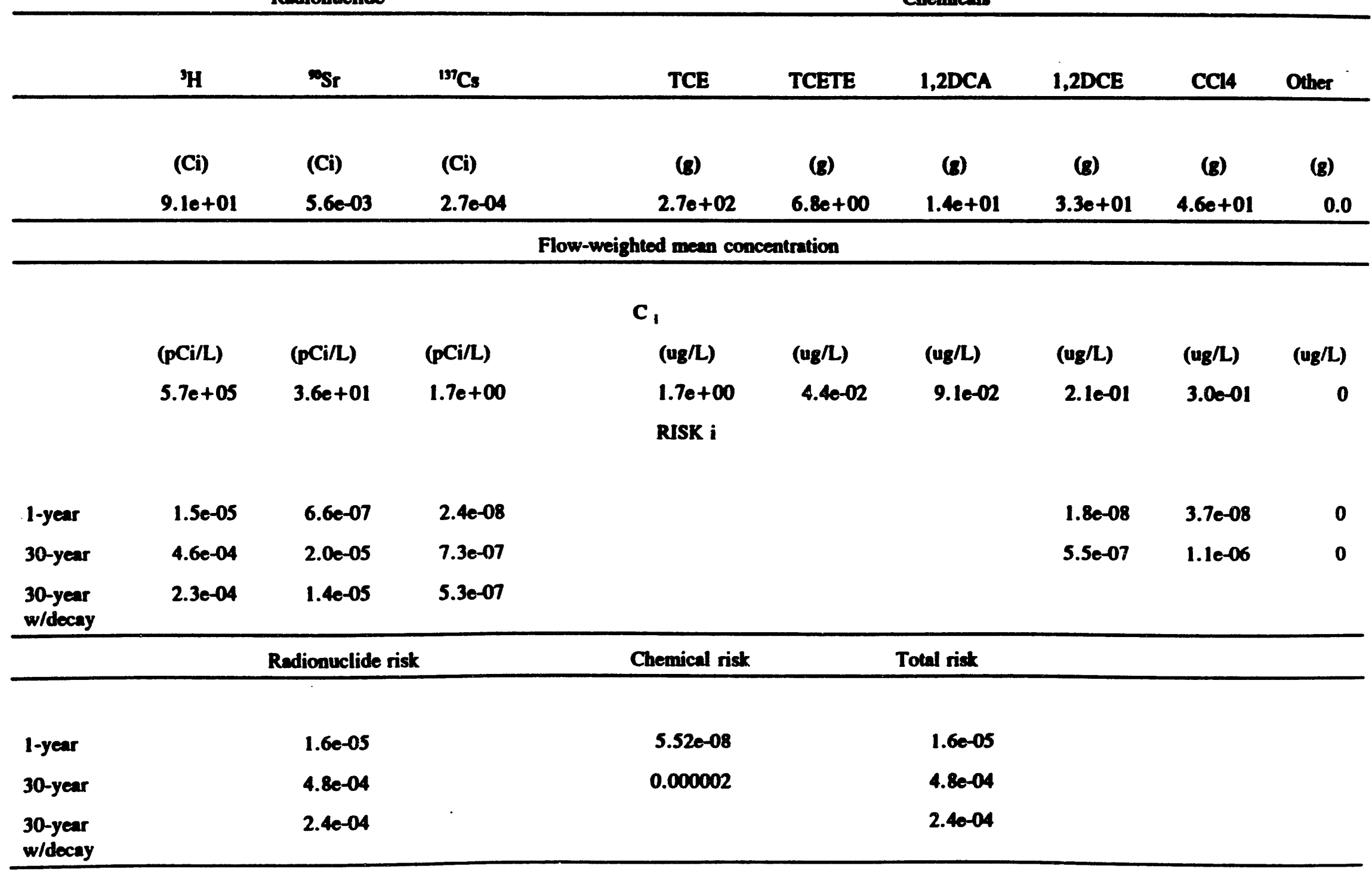

93-072P1081993 
The total risk for 30 years of water ingestion with adjustment for radionuclide decay is $2.410^{-4}$ which is higher than the $10^{4}$ criterion for "Require further investigation before taking action" for conservative estimates of exposure (Table A.6). The 1-year risk is below the criterion. The 30-year risk, without adjustment for radioactive decay, is nearly twice as great as the value with decay-adjustment, primarily because of the short half-life of ${ }^{3} \mathrm{H}$ and the fact that ${ }^{3} \mathrm{H}$ is the major contributor to risk at the WAG 6 perimeter. Tritium contributes $92 \%$ of the risk followed by ${ }^{\circ} \mathrm{Sr}$ with about $6 \%$. All of the organics plus ${ }^{23} \mathrm{Cs}$ contribute $<2 \%$ to the $30-y$ risk. All of these projections imply constant leaching and discharge with the only loss caused by radioactive decay.

Risk values at the WAG 6 perimeter can be compared to those associated with discharge at White Oak Dam (WOD) as measured in 1991. The risk values are 2.4 $10^{-4}$ and $1.710^{-4}$ for WAG 6 and WOD, respectively. When the data are adjusted for annual discharge volume the contribution to risk at WOD by WAG 6 drainage is $1.4 \%$. Other waste disposal areas, the main plant area, and the White Oak Creek (WOC) floodplain are discharging harmful contaminants at much greater levels than WAG 6.

This analysis is the first time that the site conceptual model has been implemented mathematically and combined with available monitoring data to derive current risk levels. Other risk analyses have used standard computer models to forecast discharge conditions but they tend to obscure the real flow mechanisms such as subsurface storm flow and matrix diffusion. The WAGRISK model incorporates these features for the internal drainage via the $C-Q$ relationship and at the perimeter through the use of recharge values for each subsurface flow zone. Implementation of the concepts inherent to the WAGRISK model after baseline data collection will be even more sophisticated by incorporating the results of groundwater modeling and other mathematical tools. 
Table A6. Compariaca of risk at WAG 6 perimeter and WOD

\begin{tabular}{|c|c|c|c|c|c|c|c|}
\hline Site & 1992 Data & $\begin{array}{l}\text { Annual } \\
\text { discharge }\end{array}$ & ${ }^{3} \mathbf{H}$ & ${ }^{\infty} \mathrm{Sr}$ & ${ }^{131} \mathrm{Cs}$ & ${ }^{\oplus} \mathrm{Co}$ & $\begin{array}{l}\text { Risk } \\
\text { 30-year } \\
\text { w/decay }\end{array}$ \\
\hline \multirow[t]{4}{*}{ WAG6 } & Volume (m3) & $1.5 e+05$ & & & & & \\
\hline & $C_{1}(\mathrm{pCi} / \mathrm{L})$ & & $5.7 e+05$ & $3.6 e+01$ & $1.7 e+00$ & & 2.4e- $\cap 4$ \\
\hline & AFC i (Ci) & & $9.1 e+01$ & $5.6 e-03$ & $2.7 e-04$ & & \\
\hline & RISK 30 y w/Decay & & $2.3 e-04$ & $1.4 e-05$ & $5.3 e-07$ & & \\
\hline \multicolumn{8}{|c|}{1991 Data } \\
\hline \multirow[t]{5}{*}{ WOD } & Volume (m3) & $1.5 e+07$ & & & & & \\
\hline & $C i(p C i / L)$ & & $1.4 e+05$ & $1.9 e+02$ & $1.2 e+02$ & $1.0 e+01$ & \\
\hline & AFC (Ci) & & $2.1 e+03$ & $2.8 e+00$ & $1.8 e+00$ & $1.5 e-01$ & \\
\hline & RISK 30 y w/Decay & & $5.6 e-05$ & $7.3 e-05$ & $3.6 e-05$ & $5.6 e-07$ & $1.7 e-04$ \\
\hline & Relative Flux or Risk & & 0.044 & 0.002 & $1.5 e-04$ & 0.000 & 0.015 \\
\hline
\end{tabular}


A-10

\section{REFERENCES}

BNI (Bechtel National, Inc.) 1991. RCRA Facility Investigation Report for Waste Area Grouping 6 at Oak Ridge National Laboratory, Oak Ridge, Tennessee, IRA $\$ 910930.2015$, ES/ER-22/V1\&D1, ORNL/ER/SUB-87/99053/5/V1. 


\section{APPENDIX B}

PARCC PARAMETERS 
B-3

Table B.1. PARCC parameters

Panmeter

$$
\text { - }
$$

Aluminum
Barium

Beryllium

Boros

Codmium

Calcium

Chromium

Cobalt

Copper

Iron .

Nickel

Sodium

- Silver

Lithium

- Silicon

Strontium

Tin

Titanium

Zinc

Calcium

Magnesium

Manganese

Molybdenum

Potsessium

Antimony

Vanadium
Accuracy

Method/Prop (\%Recovery)

Metals by ICP

$6010 / 3010$

$6010 / 3010$

$6010 / 3010$

$6010 / 3010$

$6010 / 3010$

6010/3010

$6010 / 3010$

6010/3010

$6010 / 3010$

6010/3010

6010/3010

$6010 / 3010$

6010/3010

6010/3010

$6010 / 3010$

$6010 / 3010$

6010/3010

6010/3010

$6010 / 3010$

6010/3010

6010/3010

6010/3010

6010/3010
75-125

75-125

75-125

75-125

75-125

75-125

75-125

75-125

75-125

75-125

75-125

75-125

$75-125$

75-125

75-125

75-125

75-125

75-125

75-125

75-125

75-125

75-125

75-125

75-125

75-125

75-125

0-20

0-20

0-20

0-20

0-20

0-20

0-20

0-20

0-20

0-20

0-20

0-20

0-20

0-20

0-30

0-20

0-20

0-20

0-20

0-20

0-20

$0-20$

0-20

0-20

$0-20$

75-125
Completeness

(\%)

PQL 
Table B.1. (continued)

\begin{tabular}{|c|c|c|c|c|c|}
\hline Parameter & Method/Prep & $\begin{array}{l}\text { Accuracy } \\
\text { \% Recovery) }\end{array}$ & $\begin{array}{l}\text { Precision } \\
\text { (\% RPD) } \\
\end{array}$ & $\begin{array}{c}\text { Completeness } \\
(\%) \\
\end{array}$ & PQL \\
\hline \multicolumn{6}{|c|}{ Metals by GFAA } \\
\hline Arsenic & $7060 / 3010$ & $75-125$ & $0-20$ & $96-100$ & 10 ugh \\
\hline Lead & $7421 / 3010$ & $75-125$ & $0-20$ & $96-100$ & 3ug/L \\
\hline Selenium & $7740 / 3010$ & $75-125$ & $0-20$ & $96-100$ & Sugh \\
\hline Thrallium & $7841 / 3010$ & $75-125$ & $0-20$ & $96-100$ & $10 u g / L$ \\
\hline \multicolumn{6}{|c|}{ Metals by CVAA } \\
\hline Mercury & $7470 / 7470$ & $75-125$ & $0-20$ & $96-100$ & $.2 u g / L$ \\
\hline
\end{tabular}




\section{B-5}

Table B.1. (continued)

\begin{tabular}{|c|c|c|c|c|c|}
\hline Parameler & Method/Prep & $\begin{array}{c}\text { Accuracy } \\
\text { (\%Recovery) }\end{array}$ & $\begin{array}{l}\text { Precision } \\
\text { (\% RPD) }\end{array}$ & $\begin{array}{c}\text { Completeness } \\
(\%)\end{array}$ & PQL \\
\hline \multicolumn{6}{|c|}{ Miscellaneous } \\
\hline Bromide2 & 300 & $75-125$ & $0-20$ & $96-100$ & $1 \mathrm{mg} / \mathrm{L}$ \\
\hline Chloride & 300 & $75-125$ & $0-20$ & $96-100$ & $1 \mathrm{mg} / \mathrm{h}$ \\
\hline Iodide? & 300 & $75-125$ & $0-20$ & $96-100$ & $10 \mathrm{mg} / \mathrm{L}$ \\
\hline $\mathrm{NO}_{3}$ & 300 & $75-125$ & $0-30$ & $96-100$ & $.05 \mathrm{mg} / \mathrm{L}$ \\
\hline PO, & 300 & $75-125$ & $0-20$ & $96-100$ & .061 ug $/ \mathrm{L}$ \\
\hline 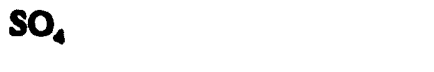 & 300 & $75-125$ & $0-30$ & $96-100$ & $5.0 \mathrm{mg} / \mathrm{L}$ \\
\hline Diseolved Organic Carbon & 415.1 & $60-140$ & $0-40$ & $96-100$ & $1 \mathrm{mg} / \mathrm{L}$ \\
\hline Discolved Inorganic Carbon & $415.1^{2}$ & $60-140$ & $0-40$ & $96-100$ & $1 \mathrm{mg} / \mathrm{L}$ \\
\hline Alkalinity & 310.1 & $75-125$ & $0-30$ & $96-100$ & $1 \mathrm{mg} / \mathrm{L}$ \\
\hline
\end{tabular}


Table B.1. (continued)

\begin{tabular}{|c|c|c|c|c|c|}
\hline Panmoter & Mothod/Prep ( & $\begin{array}{l}\text { Accuracy } \\
\text { \%Recovery) }\end{array}$ & $\begin{array}{l}\text { Precision } \\
\text { (\% RPD) }\end{array}$ & $\begin{array}{c}\text { Completeness } \\
(\mathbf{X})\end{array}$ & PQL \\
\hline \multicolumn{6}{|c|}{ Semi-Volatile Organic Compounds } \\
\hline 1,3-Dichlorobenzene & $\begin{array}{c}8270 / 35100 r \\
3520\end{array}$ & $10-172$ & $0-41$ & $96-100$ & 10. $\mu g / L$ \\
\hline 1,4-Dichlorobenzene & $\begin{array}{c}8270 / 3510 \text { or } \\
3520\end{array}$ & $36-97$ & $0-28$ & $96-100$ & 10. $\mu g / L$ \\
\hline Hexechloroethane & $\begin{array}{c}8270 / 3510 \text { or } \\
3520\end{array}$ & $40-113$ & $0-40$ & $96-100$ & 10. $\mu g / L$ \\
\hline Bis (2-chloroethyl) ether & $\begin{array}{c}8270 / 3510 \text { or } \\
3520\end{array}$ & $10-150$ & $0-50$ & $96-100$ & 10. $\mu g / L$ \\
\hline 1,2-Dichlorobenzene & $\begin{array}{c}8270 / 3510 \text { or } \\
3520\end{array}$ & $32-129$ & $0-40$ & $96-100$ & 10. $\mu g / L$ \\
\hline Bis (2-chloroisopropyl) ether & $\begin{array}{c}8270 / 3510 \text { or } \\
3520\end{array}$ & $36-166$ & $0-46$ & $96-100$ & 10. $\mu g / L$ \\
\hline N-Nitrosodipropylamine & $\begin{array}{c}8270 / 3510 \text { or } \\
3520\end{array}$ & $41-116$ & $0-38$ & $96-100$ & 10. $\mu g / L$ \\
\hline Nitrobenzence & $\begin{array}{c}8270 / 3510 \text { or } \\
3520\end{array}$ & $35-180$ & $0-40$ & $96-100$ & 10. $\mu g / L$ \\
\hline Hexechloro-1,3-butadiene & $\begin{array}{c}8270 / 35100 r \\
3520\end{array}$ & $24-116$ & $0-40$ & $96-100$ & 10. $\mu g / L$ \\
\hline 1,2,4-Trichlorobenzene & $\begin{array}{c}8270 / 3510 \text { or } \\
3520\end{array}$ & $44-142$ & $0-28$ & $96-100$ & 10. $\mu g / L$ \\
\hline Isophorone & $\begin{array}{c}8270 / 3510 \text { or } \\
3520\end{array}$ & $21-196$ & $0-60$ & $96-100$ & 10. $\mu g / L$ \\
\hline Naphthaleace & $\begin{array}{c}8270 / 3510 \text { or } \\
3520\end{array}$ & $21-133$ & $0-40$ & $96-100$ & 10. $\mu g / L$ \\
\hline Bis (2-chloroethoxy) methane & $\begin{array}{c}8270 / 3510 \text { or } \\
3520\end{array}$ & $33-184$ & $0-43$ & $96-100$ & 10. $\mu g / L$ \\
\hline Hexechlorocyclopentediene & $\begin{array}{c}8270 / 3510 \text { or } \\
3520\end{array}$ & $10-150$ & 0.50 & $96-100$ & 10. $\mu g / L$ \\
\hline Acensphthylene & $\begin{array}{c}8270 / 3510 \text { or } \\
3520\end{array}$ & $33-145$ & $0-40$ & $96-100$ & 10. $\mu g / L$ \\
\hline Acenaphthene & $\begin{array}{c}8270 / 3510 \text { or } \\
3520\end{array}$ & $46-118$ & $0-31$ & $96-100$ & 10. $\mu g / L$ \\
\hline Dimethyl phthalate & $\begin{array}{c}8270 / 3510 \text { or } \\
3520\end{array}$ & $10-112$ & $0-40$ & $96-100$ & 10ug/L \\
\hline
\end{tabular}


B-7

Table B.1. (continued)

\begin{tabular}{|c|c|c|c|c|c|}
\hline Panmeter & Method/Prep ( & $\begin{array}{l}\text { Accuracy } \\
\text { ORecovery) }\end{array}$ & $\begin{array}{l}\text { Precision } \\
\text { ( } \% \text { RPD) }\end{array}$ & $\begin{array}{c}\text { Completeness } \\
(\%)\end{array}$ & PQL \\
\hline 2,6-Dinitrotoluene & $\begin{array}{c}8270 / 3510 \text { or } \\
3520\end{array}$ & $39-139$ & $0-40$ & $96-100$ & 10. $\mu g / L$ \\
\hline Fluorene & $\begin{array}{c}8270 / 3510 \text { or } \\
3520\end{array}$ & $54-121$ & $0-40$ & $96-100$ & 10. $\mu g / L$ \\
\hline 2,4-Dinitrotoluene & $\begin{array}{c}8270 / 3510 \text { or } \\
3520\end{array}$ & $24-96$ & $0-38$ & $96-100$ & 10. $\mu g / L$ \\
\hline Diethyl phthalate & $\begin{array}{c}8270 / 35100 r \\
3520\end{array}$ & $10-114$ & $0-40$ & $96-100$ & 10. $\mu g / L$ \\
\hline N-Nitroeodiphenylamine & $\begin{array}{c}8270 / 3510 \text { or } \\
3520\end{array}$ & $41-116$ & $0-38$ & $96-100$ & 10. $\mu g / L$ \\
\hline Hexechlorobensene & $\begin{array}{c}8270 / 3510 \text { or } \\
3520\end{array}$ & $10-152$ & $0-40$ & $96-100$ & 10. $\mu g / L$ \\
\hline 4-Bromopheayl phenyl ether & $\begin{array}{c}8270 / 3510 \text { or } \\
3520\end{array}$ & $53-127$ & $0-40$ & $96-100$ & 10. $\mu \mathrm{g} / \mathrm{L}$ \\
\hline Phennithreace & $\begin{array}{c}8270 / 35100 r \\
3520\end{array}$ & $54-120$ & $0-40$ & $96-100$ & 10. $\mu g / \lambda$. \\
\hline Anthracene & $\begin{array}{c}8270 / 3510 \text { or } \\
3520\end{array}$ & $27-133$ & 0.40 & $96-100$ & 10. $\mu g / L$ \\
\hline Di-n-butyl phthalate & $\begin{array}{c}8270 / 3510 \text { or } \\
3520\end{array}$ & $10-118$ & $0-50$ & $96-100$ & 10ug/h \\
\hline Fluoranthese & $\begin{array}{c}8270 / 3510 \text { or } \\
3520\end{array}$ & $26-137$ & $0-40$ & $96-100$ & $10 \mu g / L$ \\
\hline Pyrene & $\begin{array}{c}8270 / 3510 \text { or } \\
3520\end{array}$ & $26-127$ & $0-31$ & $96-100$ & 10. $\mu g / L$ \\
\hline Butyl benzyl phthalate & $\begin{array}{c}8270 / 3510 \text { or } \\
3520\end{array}$ & $10-152$ & $0-40$ & $96-100$ & 10. $\mu g / L$ \\
\hline Bis (2-ethylbexyl) phthalate & $\begin{array}{c}8270 / 3510 \text { or } \\
3520\end{array}$ & $10-158$ & $0-40$ & $96-100$ & 10. $\mu g / L$ \\
\hline Chryeene & $\begin{array}{c}8270 / 3510 \text { or } \\
3520\end{array}$ & $17-168$ & $0-48$ & $96-100$ & 10. $\mu g / L$ \\
\hline Benso [a] anthracene & $\begin{array}{c}8270 / 3510 \text { or } \\
3520\end{array}$ & $33-143$ & $0-40$ & $96-100$ & 10. $\mu g / L$ \\
\hline 3,3'-Dichlorobenzidine & $\begin{array}{c}8270 / 3510 \text { or } \\
3520\end{array}$ & $10-162$ & 0.100 & $96-100$ & 20. $\mu g /$ \\
\hline Di-n-octyl phthalate & $\begin{array}{c}8270 / 3510 \text { or } \\
3520\end{array}$ & $10-146$ & $0-50$ & $96-100$ & 10. $\mu g /$ \\
\hline
\end{tabular}


Table B.1. (continued)

\begin{tabular}{|c|c|c|c|c|c|}
\hline Panmoter & Method/Prep ( & $\begin{array}{l}\text { Accuracy } \\
\text { \% Recovery) }\end{array}$ & $\begin{array}{l}\text { Precision } \\
\text { (\% RPD) }\end{array}$ & $\begin{array}{c}\text { Completeness } \\
(\%)\end{array}$ & PQL \\
\hline Beazo [b] fluornathene & $\begin{array}{c}8270 / 35100 r \\
3520\end{array}$ & $24-159$ & $0-40$ & $96-100$ & 10. $\mu g / L$ \\
\hline Beazo [k] fluoranthene & $\begin{array}{c}8270 / 3510 \text { or } \\
3520\end{array}$ & $11-162$ & $0-42$ & $96-100$ & 10. $\mu g / L$ \\
\hline Benzo [a] pyrene & $\begin{array}{c}8270 / 3510 \text { or } \\
3520\end{array}$ & $17-163$ & $0-40$ & $96-100$ & 10. $\mu g / L$ \\
\hline Indeno $[1,2,3-\mathrm{cd}]$ pyrene & $\begin{array}{c}8270 / 3510 \text { or } \\
3520\end{array}$ & $10-171$ & $0-45$ & $96-100$ & 10. $\mu g / L$ \\
\hline Dibenz $[\mathbf{a}, \mathbf{h}]$ anthracene & $\begin{array}{c}8270 / 35100 r \\
3520\end{array}$ & $10-227$ & $0-70$ & $96-100$ & 10. $\mu g / L$ \\
\hline Benzo [ghi] perylene & $\begin{array}{c}8270 / 3510 \text { or } \\
3520\end{array}$ & $10-219$ & $0-56$ & $96-100$ & 10. $\mu g / L$ \\
\hline 2-Chlorophenol & $\begin{array}{c}8270 / 3510 \text { or } \\
3520\end{array}$ & $27-123$ & $0-40$ & $96-100$ & 10. $\mu g / L$ \\
\hline Phenol & $\begin{array}{c}8270 / 35100 r \\
3520\end{array}$ & $5-112$ & $0-42$ & $96-100$ & 10. $\mu g / L$ \\
\hline 2,4-Dimethylphenol & $\begin{array}{c}8270 / 35100 r \\
3520\end{array}$ & $32-119$ & $0-40$ & $96-100$ & 10. $\mu g / L$ \\
\hline 2,4-Dichlorophenol & $\begin{array}{c}8270 / 3510 \text { or } \\
3520\end{array}$ & $39 \cdot 135$ & $0-40$ & $96-100$ & 10. $\mu g / L$ \\
\hline 2,4,6-Trichlorophenol & $\begin{array}{c}8270 / 3510 \text { or } \\
3520\end{array}$ & $37-144$ & $0-40$ & $96-100$ & 10. $\mu g / L$ \\
\hline 2,4-Dinitrophenol & $\begin{array}{c}8270 / 35100 r \\
3520\end{array}$ & $10-191$ & $0-50$ & $96-100$ & 50. $\mu \mathrm{g} / \mathrm{L}$ \\
\hline Peatachlorophenol & $\begin{array}{c}8270 / 3510 \text { or } \\
3520\end{array}$ & $9-103$ & $0-50$ & $96-100$ & 50. $\mu \mathrm{g} / \mathrm{L}$ \\
\hline Benzyl alcobol & $\begin{array}{c}8270 / 3510 \text { or } \\
3520\end{array}$ & $10-150$ & $0-50$ & $96-100$ & $20 u g / 2$ \\
\hline o-Creeol (2-Methylphenol) & $\begin{array}{c}8270 / 3510 \text { or } \\
3520\end{array}$ & $10-150$ & $0-50$ & $96-100$ & 10. $\mu g / L$ \\
\hline p-Cresol (4-Methylphenol) & $\begin{array}{c}8270 / 3510 \text { or } \\
3520\end{array}$ & $10-150$ & $0-50$ & $96-100$ & 10. $\mu g / L$ \\
\hline p-Chloronniline (4-Chlorosniline) & $\begin{array}{c}8270 / 3510 \text { or } \\
3520\end{array}$ & $10-150$ & $0-50$ & $96-100$ & 20ug/L \\
\hline 2-Methylnaphthalene & $\begin{array}{c}8270 / 35100 \mathrm{r} \\
3520\end{array}$ & $10-150$ & $0-50$ & $96-100$ & 10. $\mu g / L$ \\
\hline
\end{tabular}


B-9

Table B.1. (continued)

\begin{tabular}{|c|c|c|c|c|c|}
\hline Paramoter & Method/Prep ( & $\begin{array}{l}\text { Accuracy } \\
\text { X Recovery) }\end{array}$ & $\begin{array}{l}\text { Precision } \\
\text { (\% RPD) }\end{array}$ & $\begin{array}{c}\text { Completeness } \\
(\%)\end{array}$ & PQL \\
\hline 2,4,5-Trichloropheaol & $\begin{array}{c}8270 / 35100 \mathrm{r} \\
3520\end{array}$ & $10-150$ & $0-50$ & $96-100$ & 50 oug $/ \mathrm{L}$ \\
\hline o-Nitroaniline (2-Nitroaniline) & $\begin{array}{c}8270 / 3510 \text { or } \\
3520\end{array}$ & $10-150$ & $0-50$ & $96-100$ & 50. $\mu g / L$ \\
\hline m-Nitronniline (3-Nitroaniline) & $\begin{array}{c}8270 / 35100 r \\
3520\end{array}$ & $10-150$ & $0-50$ & $96-100$ & 50. $\mu g / L$ \\
\hline Dibearofuran & $\begin{array}{c}8270 / 3510 \text { or } \\
3520\end{array}$ & $10-150$ & $0-50$ & $96-100$ & 10. $\mu g / L$ \\
\hline p-Nitronniline (4-Nitronniline) & $\begin{array}{c}8270 / 3510 \text { or } \\
3520\end{array}$ & $10-150$ & $0-50$ & $96-100$ & 50. $\mu g / L$ \\
\hline o-Nitrophenol (2-Nitrophenol) & $\begin{array}{c}8270 / 3510 \text { or } \\
3520\end{array}$ & $29-182$ & $0-40$ & $96-100$ & 10. $\mu g / L$ \\
\hline p-Chloro-m-cresol & $\begin{array}{c}8270 / 3510 \text { or } \\
3520\end{array}$ & $22-147$ & $0-42$ & $96-100$ & 20ug/L \\
\hline 4,6-Dinitro-o-creeol & $\begin{array}{c}8270 / 35100 r \\
3520\end{array}$ & $10-181$ & $0-93$ & $96-100$ & 50. $\mu g / L$ \\
\hline p-Nitrophenol & $\begin{array}{c}8270 / 3510 \text { or } \\
3520\end{array}$ & & & $96-100$ & 50. $\mu g / L$ \\
\hline Benzoic acid & $\begin{array}{c}8270 / 35100 r \\
3520\end{array}$ & $10-150$ & $0-50$ & $96-100$ & 50. $\mu g / L$ \\
\hline
\end{tabular}


Table B.1. (continued)

\begin{tabular}{|c|c|c|c|c|c|}
\hline Parameter & Method/Prep ( & $\begin{array}{c}\text { Accuracy } \\
\text { (\%ocovery) }\end{array}$ & $\begin{array}{l}\text { Precision } \\
(\% \text { RPD) } \\
\end{array}$ & $\begin{array}{c}\text { Completeness } \\
(\%)\end{array}$ & PQL \\
\hline \multicolumn{6}{|c|}{ Volatile Organic Compounds } \\
\hline Acetone & 8240 & $47-143$ & $0-40$ & $96-100$ & 100ug/L \\
\hline Bensene & 8240 & $76-127$ & $0-11$ & $96-100$ & 5. $\mu g / L$ \\
\hline Methyl chloride (Chloromethnne) & 8240 & $10-140$ & $0-60$ & $96-100$ & 10. $\mu g / \mathrm{L}$ \\
\hline Methyl bromide (Bromomethne) & 8240 & $10-170$ & 0.65 & $96-100$ & 10. $\mu g / L$ \\
\hline Vinyl chloride & 8240 & $10-181$ & $0-87$ & $96-100$ & 10. $\mu \mathrm{g} / \mathrm{L}$ \\
\hline $\begin{array}{l}\text { Methylene chloride } \\
\text { (Dichloromethnne) }\end{array}$ & 8240 & $41-177$ & $0-40$ & $96-100$ & 5. $\mu g / L$ \\
\hline Carbon diaulfide & 8240 & $53-148$ & $0-40$ & $96-100$ & 5. $\mu g \Omega$ \\
\hline 1,1-Dichloroethylene & 8240 & & & $96-100$ & 5. $\mu \mathrm{g} / \mathrm{L}$ \\
\hline 1,1-Dichloroethrne & 8240 & $10-169$ & $0-43$ & $96-100$ & 5. $\mu g / L$ \\
\hline 1,2-Dichloroethane & 8240 & $56-146$ & $0-40$ & $96-100$ & 5. $\mu g / L$ \\
\hline Chloroform & 8240 & $60-140$ & $0-40$ & $96-100$ & 5. $\mu g / L$ \\
\hline 2-Butanose (Methyl ethyl ketone) & 8240 & $46-153$ & $0-40$ & $96-100$ & $100 u g / L$ \\
\hline 1,1,1-Trichloroethane & 8240 & $55-150$ & $0-40$ & $96-100$ & 5. $\mu \mathrm{g} / \mathrm{L}$ \\
\hline Carbon totrachloride & 8240 & $71-140$ & $0-40$ & $96-100$ & 5. $\mu g / L$ \\
\hline Vingl scetare & 8240 & $39-151$ & $0-50$ & $96-100$ & soug/L \\
\hline Bromodichloromethane & 8240 & $35-155$ & $0-40$ & $96-100$ & 5. $\mu \mathrm{g} / \mathrm{L}$ \\
\hline 1,1,2,2-Tetrechloroethane & 8240 & $54-142$ & $0-40$ & $96-100$ & 5. $\mu g / L$ \\
\hline 1,2-Dichloropropane & 8240 & $10-162$ & $0-55$ & $96-100$ & 5. $\mu g / L$ \\
\hline Trichloroethene & 8240 & $71-120$ & $0-14$ & $96-100$ & 5. $\mu g / L$ \\
\hline Dibromochloromethane & 8240 & $56-142$ & $0-40$ & $96-100$ & 5. $\mu g / L$ \\
\hline 1,1,2-Trichloroethane & 8240 & $53-152$ & $0-40$ & $96-100$ & 5. $\mu \mathrm{g} / \mathrm{L}$ \\
\hline Bromoform & 8240 & $46-169$ & 0.40 & $96-100$ & 5. $\mu g / L$ \\
\hline 2-Hexanone & 8240 & $49-151$ & $0-40$ & $96-100$ & soug/L \\
\hline 4-Methyl-2-pentanone & 8240 & $46-152$ & 0.40 & $96-100$ & 50 ug/L \\
\hline Tetrachloroethene & 8240 & $70-140$ & $0-40$ & $96-100$ & 5. $\mu g / L$ \\
\hline Toluene & 8240 & $76-125$ & $0-13$ & $96-100$ & 5. $\mu g / L$ \\
\hline Chlorobenzene & 8240 & $75-130$ & $0-13$ & $96-100$ & 5. $\mu g /$ \\
\hline
\end{tabular}


B-11

Table B.1. (continued)

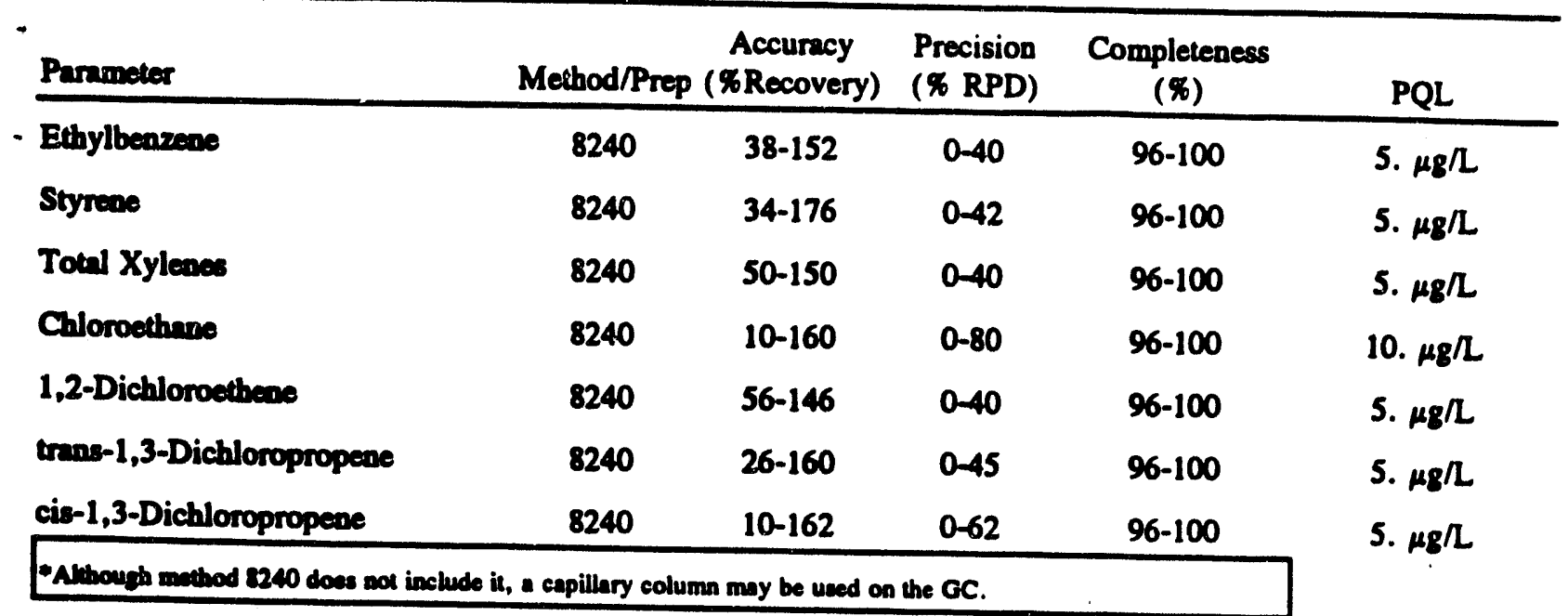


B-12

Table B.1. (continued)

\begin{tabular}{|c|c|c|c|c|c|}
\hline Parnmeter & Method/Prep ( & $\begin{array}{l}\text { Accuracy } \\
\text { 6Recovery) }\end{array}$ & $\begin{array}{l}\text { Precision } \\
\text { (\% RPD) }\end{array}$ & $\begin{array}{c}\text { Completeness } \\
(\%)\end{array}$ & PQL \\
\hline \multicolumn{6}{|c|}{ Pesticicides/PCB's } \\
\hline Aldrin & $\begin{array}{c}8080 / 3510 \text { or } \\
3520\end{array}$ & $40-130$ & $0-20$ & $96-100$ & $.04 u g / L$ \\
\hline$\triangle-B H C$ & $\begin{array}{c}8080 / 35100 r \\
3520\end{array}$ & $40-130$ & $0-20$ & $96-100$ & $.03 u g / L$ \\
\hline B-BHC & $\begin{array}{c}8080 / 3510 \text { or } \\
3520\end{array}$ & $40-130$ & $0-20$ & $96-100$ & $.06 u g / L$ \\
\hline Sigmn-BHC & $\begin{array}{c}8080 / 35100 r \\
3520\end{array}$ & $40-130$ & $0-20$ & $96-100$ & $.09 u g / L$ \\
\hline Lindane & $\begin{array}{c}8080 / 3510 \text { or } \\
3520\end{array}$ & $40-130$ & $0-20$ & $96-100$ & $.04 u g / L$ \\
\hline Chlordane & $\begin{array}{c}8080 / 35100 r \\
3520\end{array}$ & $40-130$ & 0.20 & $96-100$ & $.14 u g / L$ \\
\hline 4,4'-DDD & $\begin{array}{c}8080 / 3510 \text { or } \\
3520\end{array}$ & $40-130$ & $0-20$ & $96-100$ & .11 ug/L \\
\hline 4,4'-DDE & $\begin{array}{c}8080 / 3510 \text { or } \\
3520\end{array}$ & $40-130$ & $0-20$ & $96-100$ & $.04 u g / L$ \\
\hline $4,4^{\circ}-\mathrm{DDT}$ & $\begin{array}{c}8080 / 35100 r \\
3520\end{array}$ & $40-130$ & $0-20$ & $96-100$ & $.12 \mathrm{ug} / \mathrm{L}$ \\
\hline Dieldrin & $\begin{array}{c}8080 / 3510 \text { or } \\
3520\end{array}$ & $40-130$ & $0-20$ & $96-100$ & $.02 u g / L$ \\
\hline Endocoulfan I & $\begin{array}{c}8080 / 35100 \mathrm{r} \\
3520\end{array}$ & $40-130$ & $0-20$ & $96-100$ & $.14 u g / L$ \\
\hline Endosulfan II & $\begin{array}{c}8080 / 35100 r \\
3520\end{array}$ & $40-130$ & $0-20$ & $96-100$ & $.04 u g / L$ \\
\hline Endosulfan Sulfate & $\begin{array}{c}8080 / 35100 r \\
3520\end{array}$ & $40-130$ & 0.20 & $96-100$ & $.66 u g / L$ \\
\hline Endrin & $\begin{array}{c}8080 / 35100 r \\
3520\end{array}$ & $40-130$ & 0.20 & $96-100$ & $.06 u g / L$ \\
\hline Endrin Aldebyde & $\begin{array}{c}8080 / 35100 r \\
3520\end{array}$ & $40-130$ & $0-20$ & $95-100$ & $.23 u g / L$ \\
\hline Heptachlor & $\begin{array}{c}8080 / 35100 r \\
3520\end{array}$ & $40-130$ & $0-20$ & $96-100$ & $.03 u g / L$ \\
\hline Heptachlor Epoxide & $\begin{array}{c}8080 / 35100 r \\
3520\end{array}$ & $40-130$ & 0.20 & $96-100$ & .83 ug $/ \mathrm{L}$ \\
\hline
\end{tabular}


B-13

Table B.1. (continued)

\begin{tabular}{|c|c|c|c|c|c|}
\hline Parnmeter & Method/Prep ( & $\begin{array}{l}\text { Accuracy } \\
\text { \%Recovery) }\end{array}$ & $\begin{array}{l}\text { Precision } \\
\text { (\% RPD) }\end{array}$ & $\begin{array}{c}\text { Completeness } \\
\text { (\%) }\end{array}$ & PQL \\
\hline -Methoxychlor & $\begin{array}{c}8080 / 35100 r \\
3520\end{array}$ & $40-130$ & $0-20$ & $96-100$ & $1.76 \mathrm{ug} / \mathrm{L}$ \\
\hline Toxaphene & $\begin{array}{c}8080 / 3510 \text { or } \\
3520\end{array}$ & $40-130$ & $0-20$ & $96-100$ & $2.4 \mathrm{ug} / \mathrm{L}$ \\
\hline PCB-1016 & $\begin{array}{c}8080 / 3510 \text { or } \\
3520\end{array}$ & $40-130$ & $0-20$ & $96-100$ & $\operatorname{lug} / \mathrm{L}$ \\
\hline PCB-1221 & $\begin{array}{c}8080 / 3510 \text { or } \\
3520\end{array}$ & $40-130$ & $0-20$ & $96-100$ & $2 u g / L$ \\
\hline PCB-1232 & $\begin{array}{c}8080 / 35100 r \\
3520\end{array}$ & $40-130$ & $0-20$ & $96-100$ & lug/L \\
\hline PCB-1242 & $\begin{array}{c}8080 / 35100 r \\
3520\end{array}$ & $40-130$ & $0-20$ & $96-100$ & lug/1 \\
\hline PCB-1248 & $\begin{array}{c}8080 / 3510 \text { or } \\
3520\end{array}$ & $40-130$ & $0-20$ & $96-100$ & lug/L \\
\hline PCB-1254 & $\begin{array}{c}8080 / 3510 \text { or } \\
3520\end{array}$ & $40-130$ & $0-20$ & $96-100$ & $\operatorname{lug} / \mathrm{L}$ \\
\hline PCB-1260 & $\begin{array}{c}8080 / 3510 \text { or } \\
3520\end{array}$ & $40-130$ & $0-20$ & $96-100$ & lug/L \\
\hline
\end{tabular}


B-14

Table B.1. (continued)

\begin{tabular}{|c|c|c|c|c|c|}
\hline Parameter & Method/Prep & $\begin{array}{l}\text { Accuracy } \\
\text { \% Recovery) }\end{array}$ & $\begin{array}{l}\text { Precision } \\
\text { (\% RPD) }\end{array}$ & $\begin{array}{c}\text { Completeness } \\
(\%)\end{array}$ & PQL \\
\hline \multicolumn{6}{|c|}{ Radiochemistry } \\
\hline Tritium & 906.0 & $\pm 5 \%$ & $25 \%$ & $96-100$ & $500 \mathrm{pCi} / \mathrm{L}$ \\
\hline 60-Cobalt & 901.1 & $\pm 5 \%$ & $8 \%$ & $96-100$ & $1 \mathrm{pCi} / \mathrm{L}$ \\
\hline so-strontium & 905.0 & $\pm 10 \%$ & $15 \%$ & $96-100$ & $2 \mathrm{pCi} / \mathrm{L}$ \\
\hline 137-Cexium & 901.1 & $\pm 15 \%$ & $4 \%$ & $96-100$ & $1 \mathrm{pCi} / \mathrm{L}$ \\
\hline 238-Plutonium & $\begin{array}{c}\text { HASL-300 } \\
\text { ASTM } \\
\text { D8635 }\end{array}$ & $\pm 8 \%$ & $5 \%$ & $96-100$ & $1 \mathrm{pCi} / \mathrm{L}$ \\
\hline 239/240-Plutonium & $\begin{array}{c}\text { HASL-300 } \\
\text { ASTM } \\
\text { D8635 }\end{array}$ & $\pm 8 \%$ & $5 \%$ & $96-100$ & $1 \mathrm{pCi} / \mathrm{L}$ \\
\hline 244-Curium & 907.0 & $\pm 8 \%$ & $8 \%$ & $96-100$ & $1 \mathrm{pCi} / \mathrm{L}$ \\
\hline 242-Curium & 907.0 & $\pm 8 \%$ & $8 \%$ & $96-100$ & $1 \mathrm{pCi} / \mathrm{L}$ \\
\hline 241-Americium & 907.0 & $\pm 8 \%$ & $8 \%$ & $96-100$ & $1 \mathrm{pCi} / \mathrm{L}$ \\
\hline Groes Alphe & 900.0 & $\pm 5 \%$ & $8 \%$ & $96-100$ & $4 \mathrm{pCi} / \mathrm{L}$ \\
\hline Groes Beta & 900.0 & $\pm 5 \%$ & $8 \%$ & $96-100$ & $.5 \mathrm{pCi} / \mathrm{L}$ \\
\hline Gamma Spectroscopy & 901.1 & $\pm 5 \%$ & $8 \%$ & $96-100$ & $1 \mathrm{pCi} / \mathrm{L}$ \\
\hline Isotopic Uranium & 907.0 & $\pm 5 \%$ & $8 \%$ & $96-100$ & $1 \mathrm{pCi} / \mathrm{L}$ \\
\hline Isotopic Thorium & 907.0 & $\pm 5 \%$ & $8 \%$ & $96-100$ & $1 \mathrm{pCi} / \mathrm{L}$ \\
\hline
\end{tabular}

The following Semi-Volatile analytes were not on this list bur to appear on the CLP TAL: 2-Chloromaphithalene

Carbazole

4-Chlorophenyl-phenylether

The following Semi-Volatiles were on this list but not on the CLP TAL:

Benzyl Alcohol

Benzoic Acid

The following Volatile analytes were not on this list but do appear on the CLP TAL:

2-Chloroethylvinylether

All volutile analytes on this list appear on the CLP TAL. 


\section{APPENDIX C}

ESTIMATION OF ANNUAL ${ }^{3} \mathrm{H}$ FLUX AND AVERAGE CONCENTRATION FROM WAG 6 SURFACE WATER USING THE

C-Q MODEL 


\section{CONTENTS}

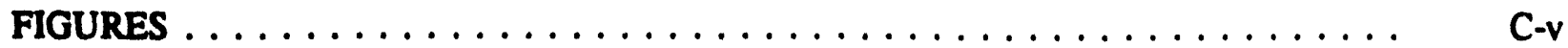

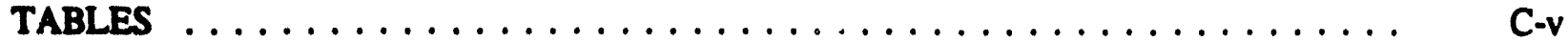

-ACRONYMS $\ldots \ldots \ldots \ldots \ldots \ldots \ldots \ldots \ldots \ldots \ldots \ldots \ldots \ldots \ldots \ldots \ldots \ldots$ C-vii

C. ESTIMATION OF ANNUAL 'H FLUX AND AVERAGE

CONCENTRATION FROM WAG 6 SURFACE WATER USING

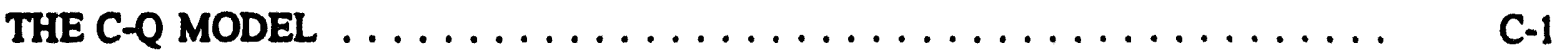

C.1 THE C-Q RELATIONSHIP . . . . . . . .

C.1.1 Purpose $\ldots \ldots \ldots \ldots \ldots \ldots \ldots \ldots \ldots \ldots \ldots \ldots \ldots \ldots \ldots \ldots, C_{\text {C-1 }}$

C.1.2 Methodology $\ldots \ldots \ldots \ldots \ldots \ldots \ldots \ldots \ldots \ldots \ldots$ C-3

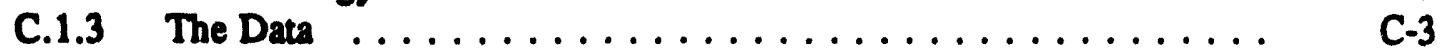

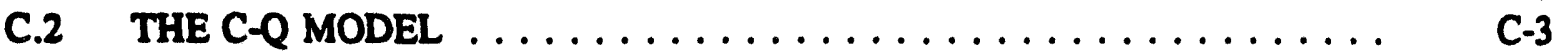

C.2.1 Annual 'H Flux and Average Concentration .......... C-8

C.3 PRELIMINARY RESULTS $\ldots \ldots \ldots \ldots \ldots \ldots \ldots \ldots \ldots \ldots$ C-11

C.4 POTENTIAL SOURCES OF UNCERTAINITY $\ldots \ldots \ldots \ldots \ldots \ldots$ C-11

C.5 MONITORING THE CHANGES $\ldots \ldots \ldots \ldots \ldots \ldots \ldots \ldots \ldots$ C-13

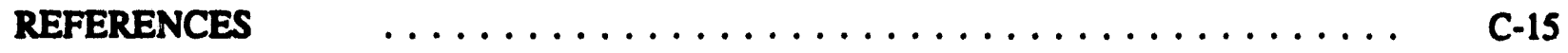

93-072P1090993 C-iii 


\section{FIGURES}

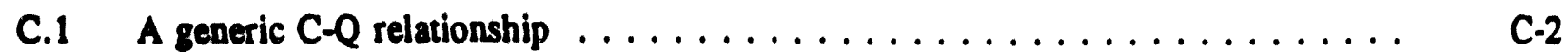

C.2 Example of $\mathrm{C}-\mathrm{Q}$ relationship $\ldots \ldots \ldots \ldots \ldots \ldots \ldots \ldots \ldots \ldots$

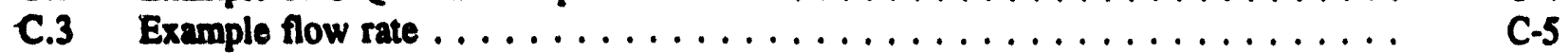

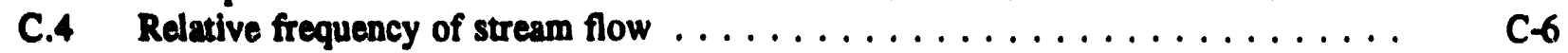

C.5 A schematic plot of $\mathrm{C}-\mathrm{Q}$ relationship $\ldots \ldots \ldots \ldots \ldots \ldots \ldots \ldots \ldots$

C.6 A statistical test of a change in concentration level ............................. c-14

\section{TABLES}

C.1 Estimated parameters of the $\mathrm{C}-\mathrm{Q}$ model $\ldots \ldots \ldots \ldots \ldots$. $\ldots \ldots \ldots$

C.2 Estimates of ${ }^{3} \mathrm{H}$ flux and average concentration for the observed period . . . . . . . . . . . . . . . . . . . . . . C-12

C.3 Estimates of annual ${ }^{3} \mathrm{H}$ flux and average concentration ............................... C 
ACRONYMS

$\begin{array}{ll}\text { C } & \text { concentration } \\ \text { DO } & \text { data quality objective } \\ \text { Q } & \text { discharge } \\ \text { SWSA } & \text { Solid Waste Storage Area } \\ \text { WAG } & \text { Waste Area Grouping }\end{array}$




\section{ESTIMATION OF ANNUAL ${ }^{3} H$ FLUX AND AVERAGE CONCENTRATION FROM WAG 6 SURFACE WATER USING THE C-Q MODEL}

\section{- C.1 THE C-Q RELATIONSHIP}

The major task of surface water monitoring is to measure the flux of contaminants leaving Waste Area Grouping (WAG) 6 and their changes over time. Contaminant fluxes in surface water are, however, known to be sensitive to climatic changes. Years with high rainfall tend to transport more dissolved contaminants than dry years because there is only partial dilution at higher flows. Therefore, an increase in annual contaminant flux or a decrease in average contaminant concentration during wet years is expected, and the reverse happens during dry years. In monitoring surface water, it is necessary to determine whether the changes in contaminant flux are caused by changes in rainfall or other changes, such as leaks in trenches and changes in vegetation. The reason is that the required remedial actions to reduce the contaminant flux in response to these two types of changes are likely to be different. Monitoring the annual contaminant flux and average concentration alone is not sufficient to discern these two types of changes statistically.

One way of detecting the change of contaminant flux that is not induced by rainfall is to monitor the discharge $(Q)$ vs concentration $(C)$ relationship. Figure $C .1$ shows a schematic plot of a generic $C-Q$ relationship. The three-piece linear function characterizes the relationship under active groundwater flow, shallow subsurface storm flow, and overland flow from transiently saturated or impervious land areas. The relationship can also be interpreted in terms of contaminant transport mechanisms. The slope of the $\log$ transformed $\mathrm{C}-\mathrm{Q}$ relationship indicates constant concentration (slope $=0)$, partial dilution $(-1<$ . slope $<0$ ), or pure dilution (slope $=-1$ ). Constant concentration indicates flows are equally contaminated and as discharge increases, contaminant flux increases. Partial dilution implies increasing contaminant flux as discharge increases, and this condition is attributed to increases in contaminated storm - flow or shallow groundwater discharge. Pure dilution implies constant contaminant flux as discharge increases, and this suggests that the water added to the system is uncontaminated. The C-Q relationships have been used effectively to evaluate changes in ${ }^{\circ} \mathrm{Sr}$ discharge at Solid Waste Storage Area (SWSA) 4 (Melroy and Huff 1985) and to infer flow mechanism for ${ }^{3} \mathrm{H}$ and ${ }^{\circ} \mathrm{Sr}$ transport in Melton Branch (Solomon a al. 1991).

The $C-Q$ relationship is expected to be relatively independent of the climate and individual storms. In addition, the $C-Q$ relationship for dissolved radionuclides, such as ${ }^{3} \mathrm{H}$ and ${ }^{90} \mathrm{Sr}$, which have a half-life of $\mathbf{1 2 . 3 6}$ and $\mathbf{2 7 . 7}$ years, respectively, should remain relatively constant from one year to the next if the drainage area under study is unchanged.

\section{C.1.1 Purpose}

The purpose of this appendix is to illustrate the use of a $\mathrm{C}-\mathrm{Q}$ model to estimate annual ${ }^{3} \mathrm{H}$ flux from WAG 6 surface water and the associated average concentration. The estimates given in this appendix are considered provisional because the data are only partially available at the time of analysis. The potential

- sources of uncertainty of the estimates are discussed. These sources of uncertainty will be scrutinized and quantified (if quantifiable) through the data quality objective (DQO) process. 


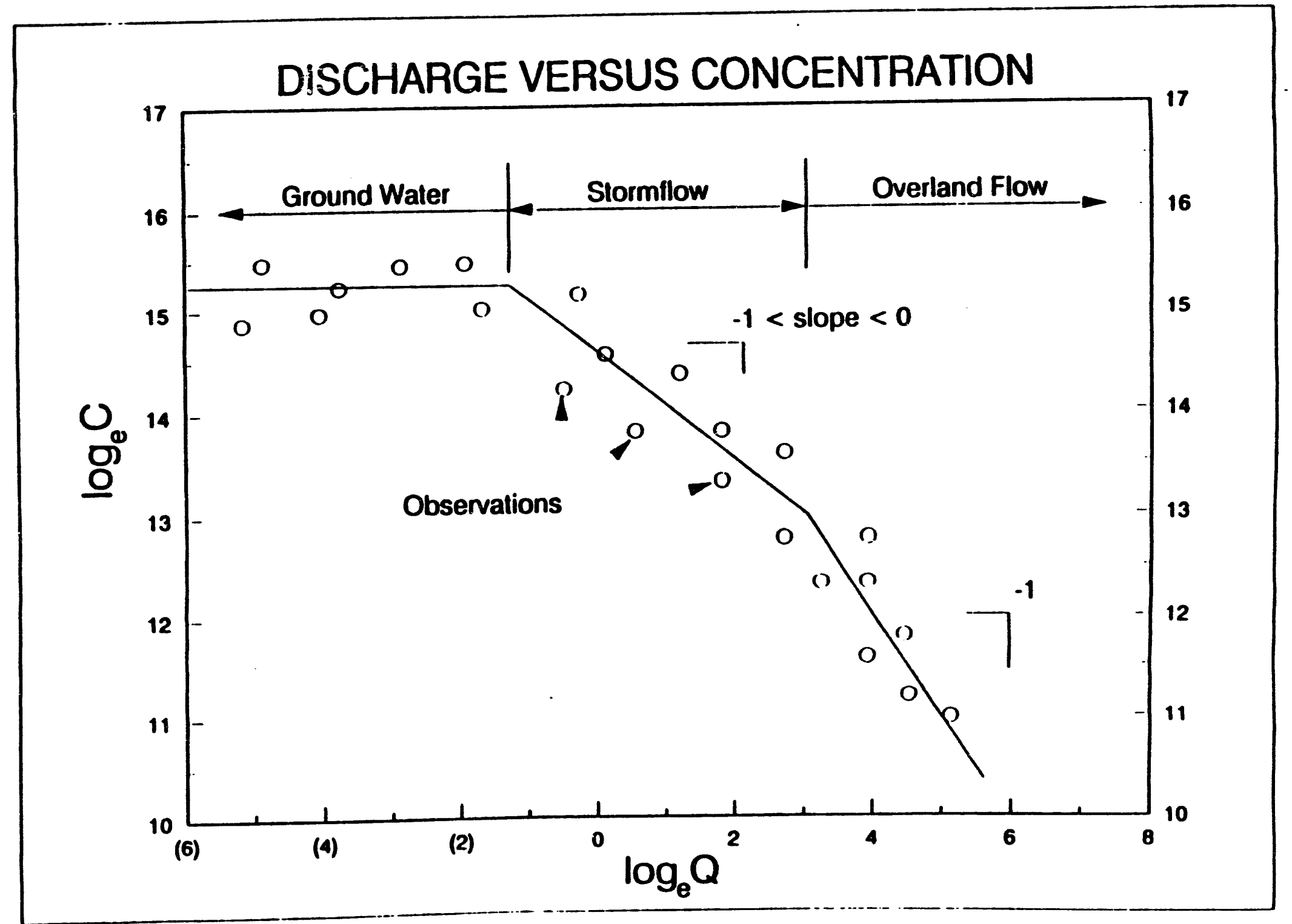

i

Fig. C.1. A generic C-Q relationship. 


\section{C.1.2 Methodology}

The relationships between discharge rate $(Q)$ and ${ }^{3} \mathrm{H}$ concentration $(C)$ for each drainage area in WAG 6 (i.e., drainage FB, DA, DB, and FA) are first established using a regression method. The regression analysis required that $Q$ and $C$ data be collected during base flow conditions (grab sampling) and storm samples be taken over the widest range of flows. A reliable $\log -\log C-Q$ relationship is judged statistically in terms of the estimated regression parameters (or coefficients) and associated standard deviations for the base flow, slopes of the storm flows, and "break points."

For a particular drainage area, the estimated annual ${ }^{3} \mathrm{H}$ flux can be computed from the developed C-Q relationship using measurements of discharge alone. Expected total annual ${ }^{3} \mathrm{H}$ flux from WAG 6 surface water is the sum of the estimated ${ }^{3} \mathrm{H}$ flux over the four drainage areas.

\section{C.1.3 The Data}

The data used in this estimation were collected by the Environmental Sciences Division staff March 1992 - February 1993. At the time of analysis, concentration data for developing $C-Q$ relationships were available only from March 1992 to August 1992, and discharge data are available at a 15-min time interval between March 1992 and February 1993 for drainage areas FB, DA, and DB. Only those data that were deemed reliable were used and missing data were not imputed. Figure C.2 shows the C-Q data for drainage FB, including 5 grab samples during base flow conditions and $42 \mathrm{storm}$ samples collected over 10 small and midsize storms. For the storms observed during period, pure dilution did not occur in any drainage area. Figure C.3 gives example flow rate for drainage FB during January 1993. Figure C. 4 is a cumulative relative frequency plot of stream flow for the observed period for drainage FB (missing data were ignored). The figure indicates that for drainage area FB during the observed period $.90 \%$ of the time the flow race is $<1 \mathrm{~L} / \mathrm{s}$. Concentrations of ${ }^{3} \mathrm{H}$ are recorded in units of pico Curie per liter $(\mathrm{pCi} / \mathrm{L})$ and discharge data are in liters per second.

\section{C.2 THE C-Q MODEL}

For each drainage area, the C-Q relationship is depicted in Fig. C.5 and is represented by a "twosegment" regression model as follows:

$$
\begin{aligned}
C_{j} & =C_{b} e^{*}, \quad \text { if } Q_{j} \leq Q_{b} \\
& =a Q_{j}^{-b} e^{2 j}, \text { if } Q_{j} \geq Q_{b}
\end{aligned}
$$

where

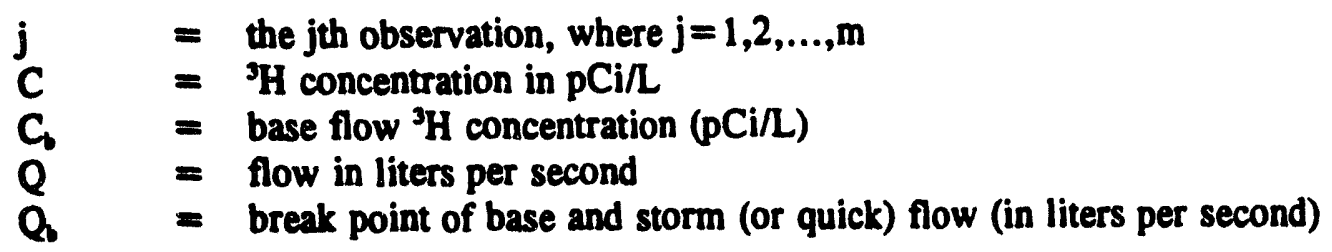




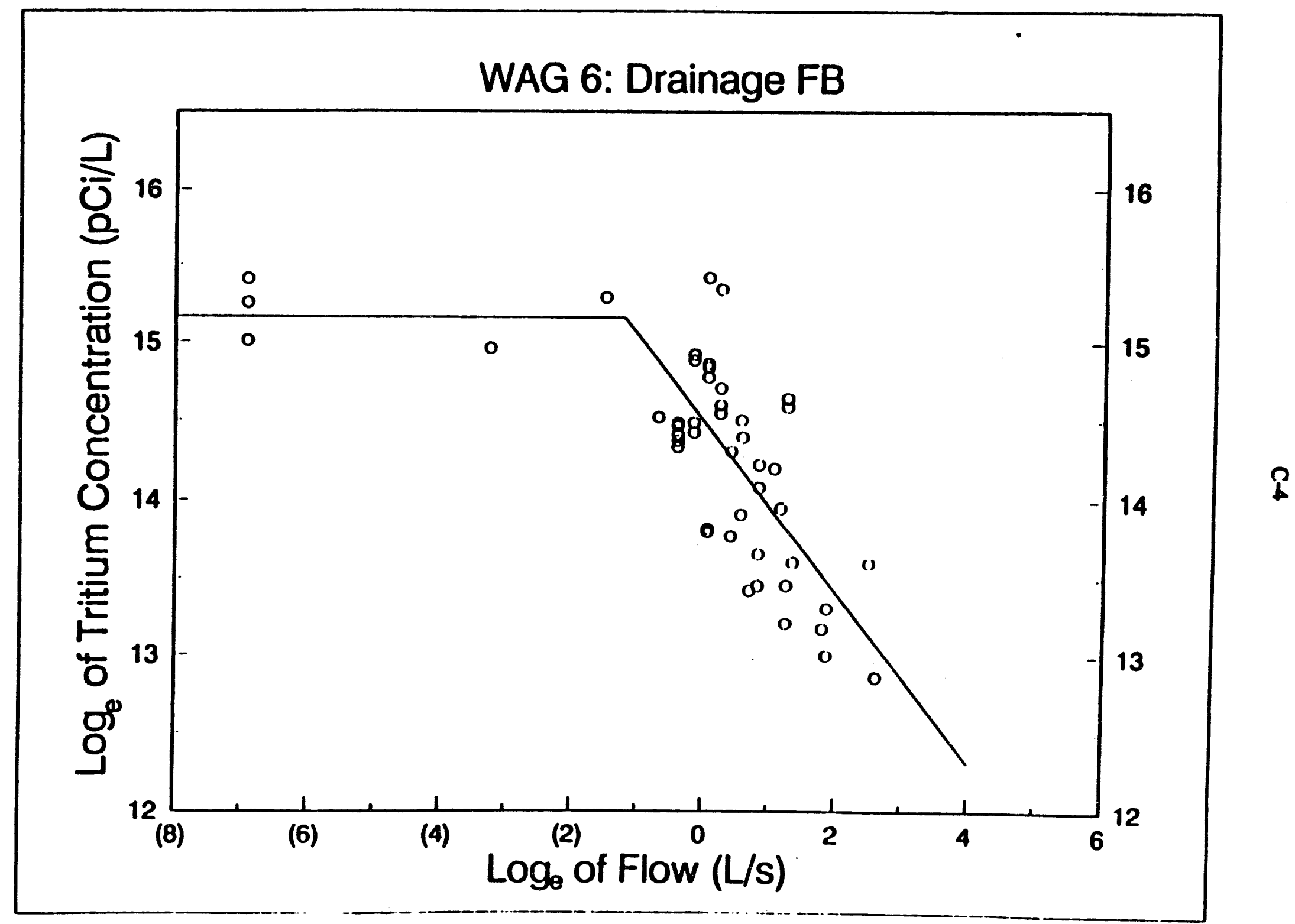

Fig. C.2. Example of C-Q relationship. 
- Breakpoinl stream flows for. The monlh of January 1993, for SWSA 6, Drainage FB

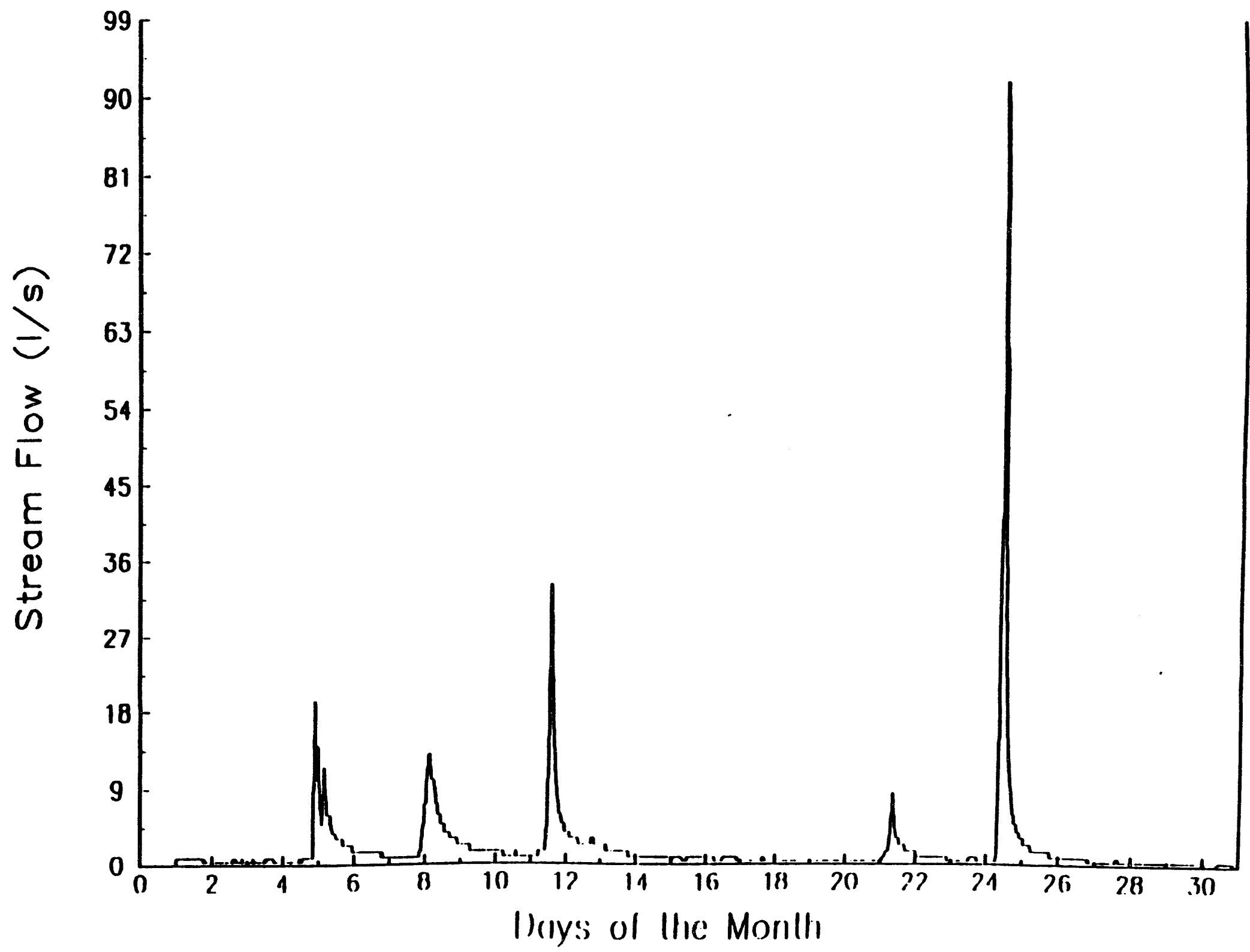

Fig. C.3. Example flow rate. 


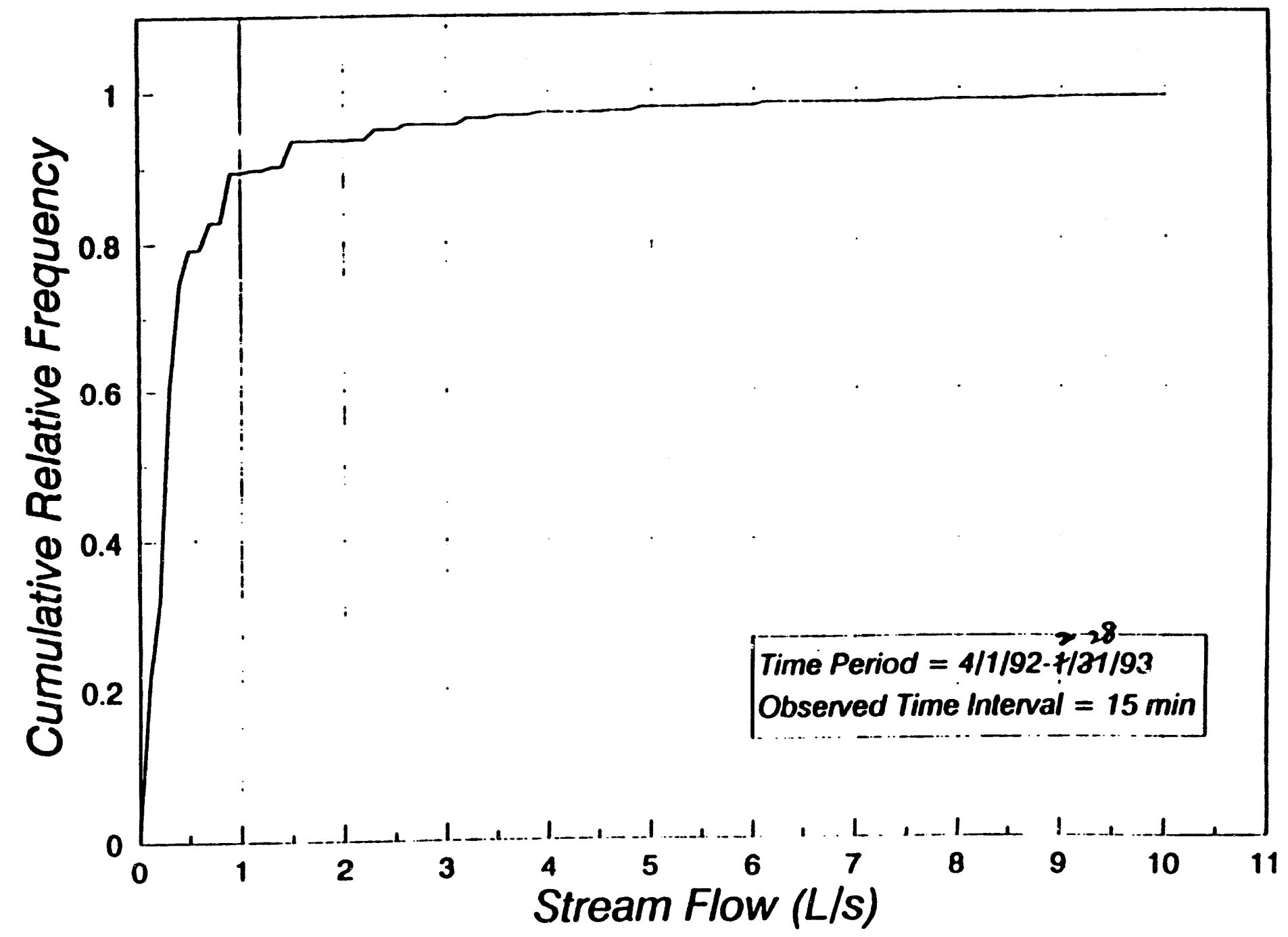

$\$$

Fig. C.4. Relative frequency of stream now. 
C-7

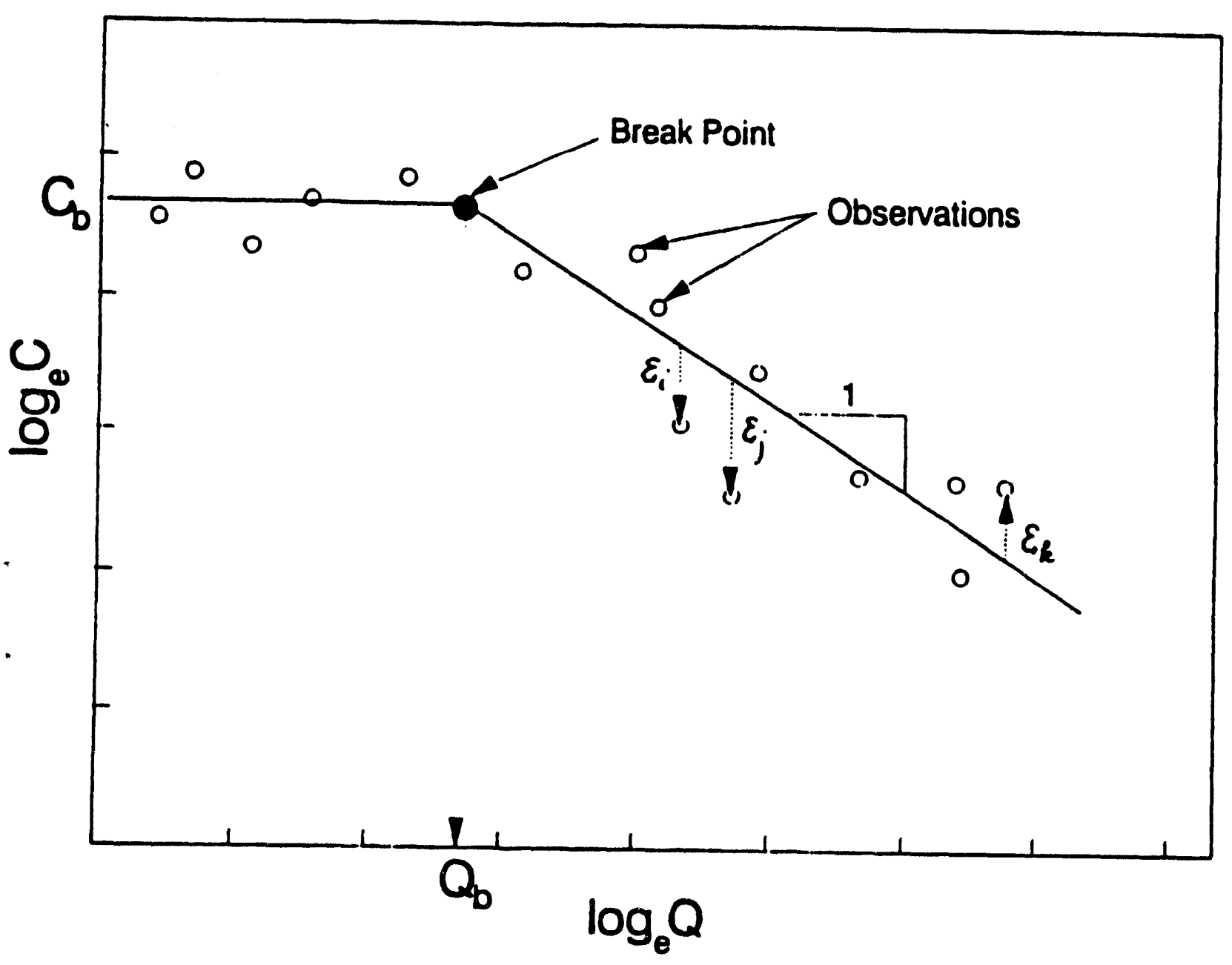

Fig. C.5. A schematic plot of $\mathrm{C}-\mathrm{Q}$ relationship. 
$\alpha, \beta=$ model parameters (constants)

$c=$ independent and normally distributed model residuals with zero mean and constant variance $\sigma_{z}^{2}$ (statistically, it is symbolized as $\varepsilon_{i}-N\left(0, \sigma_{b}^{2}\right)$.

To ensure that the two segments have the same concentration level at break point $Q$, we must have

$$
C_{b}=\alpha Q_{b}^{-\beta} \text { or } \alpha=C_{b} Q_{b}^{\beta}
$$

i.e., $\alpha$ is a function of $C_{b}, Q_{b}$, and $\beta$. If the values of $C_{b}, Q_{b}$, and $\beta$ are determined, then the value of $\alpha$ can be uniquely derived.

Equations (C-1) and (C-2) can be reexpressed in a natural log-log form as

$$
\begin{aligned}
\log \left(C_{j}\right) & =\log \left(C_{\downarrow}\right)+e_{j}, \quad \text { if } Q_{j} \leq Q_{b} \\
& =\log (\alpha)-\beta \log \left(Q_{j}\right)+\varepsilon_{j}=\log \left(C_{b}\right)-\beta\left[\log \left(Q_{j}\right)-\log \left(Q_{b}\right)\right]+e_{j}, \quad \text { if } Q_{j} \geq Q_{b}
\end{aligned}
$$

There are four unknown parameters that need to be estimated statistically in equation (C-3): $C_{b}, Q_{b}$, $\beta$, and $\sigma_{s}^{2}$. Since $\varepsilon_{j}, j=1,2, \ldots, m$, are assumed to be independent and identially distributed as normal with zero mean and constant variance, a nonlinear least squares method can be used to estimats the unknown parameters and associated statistics.

If $Q_{b}$ is known or predetermined by other physically-based methods, then equation (C-3) can be solved with the conventional linear least squares method (instead of a nonlinear least square method).

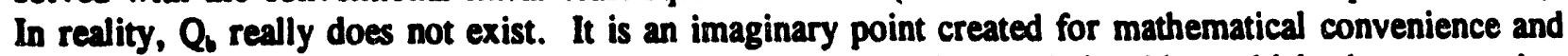
for an easy explanation of the $C-Q$ relationship. Other functional relationships, which give a smoother transition from the base flow region to the quick flow region, are possible. Also, the assumption of the model can be slightly relaxed by allowing the variance of residuals to be different for the two segments, e.g., $\sigma_{n}^{2}$ for the base flow segment and $\sigma_{z}^{2}$ for the quick flow segment. This would add one more unknown parameter $\left(\sigma_{n}^{2}\right)$ to the equation. The problem will have to be solved by an iterative nonlinear weighted least squares method.

\section{C.2.1 Annual 'H Flux and Average Concentration}

The ${ }^{3} \mathrm{H}$ flux for an observed period is defined as

$$
F=\int_{0}^{T} C_{1} Q_{1} d t
$$

where

$$
\begin{aligned}
& T=\text { the total amount of time in the period } \\
& C_{1}=\text { the concentration of }{ }^{3} \mathrm{H} \text { at time } \mathrm{t} \\
& Q_{1} \quad=\text { the flow rate at time } t \text {. }
\end{aligned}
$$

In practice, this integral is approximated by 


$$
\begin{gathered}
C-9 \\
F=\sum_{i=1}^{n} c_{i} Q_{i} \Delta t
\end{gathered}
$$

-where
n = the total number of time intervals,
$C_{i}=$ the average ${ }^{3} \mathrm{H}$ concentration during time interval $i$ (in $\mathrm{pCi} / \mathrm{L}$ )
$Q_{i}=$ the observed average flow rate (in $\left.L / s\right)$ during the ith time interval $(i=1,2, \ldots, n)$
$\Delta t=$ the time interval in seconds.

The time interval should be selected in such a way that $Q$ and $C$ are approximately constant within each time interval. [Recall $\Delta t=15 \mathrm{~min}=900$ seconds in this study].

Ideally, to compute the flux $F$, we can measure $Q$ and $C$ for every time interval. In such a case, the only uncertainty associated with the computed $F$ is the potential measurement errors of $Q$ and $C$, including instrument and human errors. If we can measure $Q$ and $C$ with negligible errors, then the flux computed from equation (C-5) is essentially error-free.

However, it is far too expensive to measure $C$ for every time interval. An alternative method is to collect $Q$ for each time interval and then obtain an estimate of $C$ using the developed $C-Q$ model, i.e., $C$ is estimated from $Q$ using equation (C-1). This method, however, introduces an additional source of uncertainty to the estimation of $F$, i.e, the uncertainty of the $C-Q$ model.

Now, by replacing $C_{i}$ with the $C-Q$ model in equation (C-1), we have

$$
\begin{aligned}
& F=\sum_{i=1}^{n}\left(C_{b} e^{\alpha^{2}}\right) Q_{i} \Delta t+\sum_{i=1}^{n}\left(\alpha Q_{i}^{-\beta} e^{\alpha_{0}}\right) Q_{i} \Delta t \\
& =\sum_{i=1}^{m}\left(C_{b} Q_{i} \Delta t\right) e^{e_{i}}+\sum_{i=1}^{i}\left(\alpha Q_{i}^{1-\theta^{i} \Delta t} \Delta e^{z_{i}}\right.
\end{aligned}
$$

where $m_{b}$ and $n_{4}$ are, respectively, the total number of time intervals where $Q_{i}$ is $\leq Q_{b}$ and $Q_{i}$ is $>Q_{b}$ $\left(\mathbf{n}=\mathbf{n}_{\mathbf{b}}+\mathbf{n}_{\mathbf{p}}\right)$.

Assuming that $\varepsilon_{i}$ is independent and identically distributed as normal with zero mean and constant variance and that flow rates $Q_{i}$ are measured without errors, the expected value of ${ }^{3} \mathrm{H}$ flux $F$ can be shown to be

$$
E(F)=\sum_{i=1}^{n_{b}}\left(C_{b} Q_{i} \Delta t\right) e^{\frac{1}{2} \sigma_{t}^{2}}+\sum_{i=1}^{n_{i}}\left(\alpha Q_{i}^{1-\beta} \Delta t\right) e^{\frac{1}{2} \sigma_{i}^{2}}
$$

An estimate of the expected flux is to replace the unknown parameters in equation (C-6) with the estimated parameters from the nonlinear least squares method: 


\section{C-10}

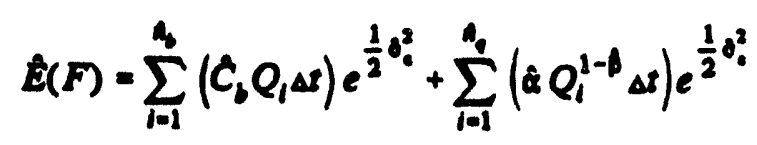

where

$$
Q=C_{b} Q_{b}^{\prime}
$$

Note that a symbolizes an estimate. Given the estimated $Q_{b}, n_{b}$ and $n_{1}$ can be determined.

The variance of the flux can be derived as follows:

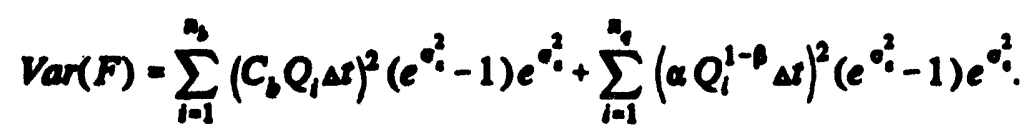

An estimate of the variance is then

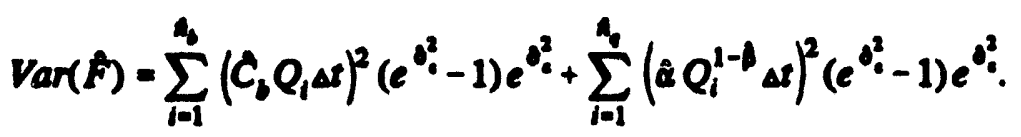

This variance is caused by the random nature of $c_{i}$ and will be called sampling errors.

An important statistic of interest is the variance of the estimated flux in equation (C-8), i.e., $\operatorname{Var}(\mathbf{E}(F))$. This variance indicates the uncertainty of flux estimate due to both the sampling errors and the uncertainty of the estimated parameters. This statistic will be derived through the DQO process.

The estimated average concentration for the observed period is

$$
\bar{C}=\frac{E(F)}{\sum_{i=1}^{n}\left(Q_{i} \Delta t\right)} .
$$

The variance of the estimated average concentration is then

$$
\operatorname{Var}(\bar{C})=\frac{\operatorname{Var}(\hat{E}(F))}{\left(\sum_{i=1}^{n} Q_{i} \Delta t\right)^{2}} .
$$




\section{C.3 PRELIMINARY RESULTS}

The unknown parameters of the $C-Q$ model were estimated using a nonlinear least squares method for each drainage area and are presented in Table C.1. Based on the C-Q model and the available flow data, 'H flux and average concentration were calculated and are presented in Table C.2 (periods with -missing data were ignored). Total numbers of valid flow data in observation-days are also given in the table. The estimates in Table C.2 were annualized and are presented in Table C.3. The annualization utilized an assumption that flow characteristics during the period where flow data are missing are the same as the rest of the period where data are available.

\section{C.4 POTENTIAL SOURCES OF UNCERTANTY}

There are several potential sources of uncertainty in estimating ${ }^{3} \mathrm{H}$ flux using the $\mathrm{C}-\mathrm{Q}$ model. These sources of uncertainty will be scrutinized and quantified (if quantifiable) through the DQO process. They are briefly discussed as follows.

- Measurement error of discharge Q: The error includes instrument and human errors. For the data considered in this appendix, errors result from difficulty in maintaining transducers and the fact that the flumes were not field rated under high flow conditions. If the data logging system is properly installed and the flumes can be field rated, it is possible to reduce this type of error to $5 \%$ or less.

- Measurement error of concentration C: If laboratory procedure is carefully carried out, this type of error is expected to be small $(<5 \%)$.

- Numerical approximation error: This error occurs when equation (C-5) is used to replace equation (C-4). If $Q_{i}$ and $C_{i}$ are the average discharge and concentration during time interval $i$, then there is no error introduced in computing $F$. However, in practice, $Q_{i}$ and $C_{i}$ are typically instantaneous measurements at a particular time point. If $Q_{i}$ and $C_{i}$ are approximately constant during the ith time interval then the error introduced in estimating $F$ will be small. A time interval of $15 \mathrm{~min}$. is currently judged to be appropriate.

- Model specification error: The size of this error depends on how good the hypothesized twosegment $C-Q$ model represents the true $C-Q$ relationship. Based on the available data, the $C-Q$ model seems to describe the variation of $C-Q$ data quite well.

- Sampling errors: This error can be statistically quantified using equation (C-11). Based on the available data, this source of error is responsible for only about $2 \%$ of the uncertainty in estimating annual ${ }^{3} \mathrm{H}$ flux.

- Uncertainty of the estimated parameters: The contribution of this source of error can be worked out statistically as described earlier. It is expected that the uncertainty of the estimated annual ${ }^{3} \mathrm{H}$ flux is increased by 5 to $10 \%$ as a result of this source of uncertainty.

- Missing data (annualization): For the current data, this error is not likely to be significant. 
C-12

Table C.1 Estimated parameters of the C-Q moded

\begin{tabular}{|c|c|c|c|c|c|c|}
\hline Dringge & $\begin{array}{c}\mathrm{C}_{\mathbf{C}} \\
(\mathrm{Ci} / \mathrm{L})\end{array}$ & $\beta$ & (L/s) & (base flow) & $\begin{array}{c}\sigma_{e}^{2} \\
\text { (quick flow) }\end{array}$ & $\begin{array}{r}\text { Adjusted R2 } \\
\text { of Eq. (C-3) }\end{array}$ \\
\hline $\mathbf{F B}$ & $\begin{array}{r}3.93413 \times 10^{-6} \\
\left( \pm 0.884 \times 10^{-9}\right)\end{array}$ & $\begin{array}{c}0.53915 \\
( \pm 0.084)\end{array}$ & $\begin{array}{c}0.27022 \\
( \pm 0.200)\end{array}$ & 0.0367 & 0.2041 & 0.58 \\
\hline DA & $\begin{array}{l}1.37450 \times 10^{6} \\
\left( \pm 0.198 \times 10^{9}\right)\end{array}$ & $\begin{array}{c}0.95318 \\
( \pm 0.065)\end{array}$ & $\begin{array}{c}1.02928 \\
( \pm 0.238)\end{array}$ & 0.2236 & 0.1354 & 0.89 \\
\hline DB & $\begin{array}{l}0.27502 \times 10^{6} \\
\left( \pm 0.096 \times 10^{-9}\right)\end{array}$ & $\begin{array}{c}0.38623 \\
( \pm 0.144)\end{array}$ & $\begin{array}{c}0.33286 \\
( \pm 0.450)\end{array}$ & 0.1647 & 0.6427 & 0.17 \\
\hline FA & & & & & & \\
\hline
\end{tabular}

Values in pareathenes are asymptomic standard deviations of estimated parameter values above.

Table C.2 Estimates of 'H nux and average concentration for the observed period

\begin{tabular}{|c|c|c|c|c|c|}
\hline \multirow{2}{*}{$\begin{array}{l}\text { Drainage (Available } \\
\text { Obaervation-Days) }\end{array}$} & \multicolumn{3}{|c|}{ JH Flux (in Ci) } & \multirow{2}{*}{$\begin{array}{c}\text { Total } \\
\text { flow volume } \\
\text { (L) }\end{array}$} & \multirow{2}{*}{$\begin{array}{c}\text { Average } \\
\text { concentration } \\
\text { (Ci/L) }\end{array}$} \\
\hline & Base flow & Quick flow & Total & & \\
\hline FB (303.55 days) & 8.48 & 22.60 & 31.08 & $20.45 \times 10^{6}$ & $1.52 \times 10^{6}$ \\
\hline DA (359.06 days) & 17.70 & 4.62 & 22.32 & $29.90 \times 10^{6}$ & $0.75 \times 10^{6}$ \\
\hline DB (356.67 days) & 0.67 & 1.70 & 2.37 & $14.02 \times 10^{6}$ & $0.17 \times 10^{6}$ \\
\hline FA & & & & & \\
\hline
\end{tabular}

Table C.3 Eotimates of annual 3 H fux and average concentration

\begin{tabular}{|c|c|c|c|c|c|}
\hline \multirow[b]{2}{*}{ Drainage } & \multicolumn{3}{|c|}{ Annual ' $\mathrm{H}$ Flux (in Ci) } & \multirow{2}{*}{$\begin{array}{l}\text { Annual total } \\
\text { flow volume } \\
\text { (L) }\end{array}$} & \multirow{2}{*}{$\begin{array}{c}\text { Average } \\
\text { concentration }(\mathrm{Ci} / \mathrm{L})\end{array}$} \\
\hline & Base flow & Quick flow & Total & & \\
\hline FB & 10.20 & 27.17 & 37.37 & $24.59 \times 10^{6}$ & $1.52 \times 10^{6}$ \\
\hline DA & 17.99 & 4.70 & 22.69 & $30.40 \times 10^{6}$ & $0.75 \times 10^{6}$ \\
\hline DB & 0.69 & 1.74 & 2.43 & $14.35 \times 10^{6}$ & $0.17 \times 10^{6}$ \\
\hline \multicolumn{6}{|l|}{$\mathbf{F A}$} \\
\hline Total & 28.88 & 33.61 & 62.49 & $69.34 \times 10^{6}$ & $0.90 \times 10^{6}$ \\
\hline
\end{tabular}




\section{C-13}

- Seasonal variations: The C-Q models developed in this appendix are based on data collected March - August 1992. Bias in estimating flux can occur if the true C-Q relationship is varying seasonally. More $C-Q$ data need to be processed to verify this kind of bias.

\section{-C.5 MONITORING THE CHANGES}

One of the quantitative rules for the DQO is to statistically determine a yearly change by a factor of 2 of the annual flux of contaminants and average concentration. However, as indicated earlier, contaminant flux and concentration in surface water are sensitive to climatic changes, and the change of contaminant transport process that is not rainfall-induced can be monitored through the change of $C-Q$ relationship. The following three possible rules can be used at the same time to monitor the change in water quality and to determine sample size requirements.

- A shift in level in the C-Q relationship as compared to the reference year.

Because the $C-Q$ relationship is relative independent of weather, one idea is to test whether there is a change in the $C-Q$ relationship between the monitored year and the referenced year. A simple statistical test for a change in level can be conducted as follows (see Fig. C.6):

$$
\begin{aligned}
\log \left(C_{j}\right) & =\log \left(C_{\downarrow}\right)+\theta I_{j}+\varepsilon_{j}, \quad \text { if } Q_{j} \leq Q_{b} \\
& =\log \left(C_{b}\right)-\beta\left[\log \left(Q_{j}\right)-\log \left(Q_{j}\right]+\theta I_{j}+\varepsilon_{j}, \text { if } Q_{j} \geq Q_{b}\right.
\end{aligned}
$$

where $I_{j}$ is a dummy variable equal to 0 if the observation was made during the reference year and equal to 1 if the observation was made during the monitored year.

The unknown parameters, including $\theta$, and their standard deviations and t-statistics can be estimated from the nonlinear least squares method mentioned earlier. If the $\theta$ is tested (using t-test) to be significantly different from zero at a 5\% $\alpha$ level, then we say there is a change in concentration level and something needs to be done about it (perhaps more studies to figure out why the change occurs). A factor of 2 change occurs when $\theta=0.69$.

Based on the data from drainage FB, to estimate $\theta$ with a value of 0.69 and a standard deviation of \pm 0.1 , a sample size of about 56 is required. It is more important, however, that samples be taken over the widest range of flows rather than the number of samples. The proposed monitoring plan is to collect 8 storms per year ( 2 per quarter) with an average of 10 samples per storm and 12 base flow samples to capture the seasonal variation.

- Determine if the estimated $E(F)$ in the monitored year is greater than the estimated $E(F)$ in the reference year by a factor of 2 or more.

- Determine if the estimated $\mathbf{C}$ in the monitored year is greater than the estimated $\mathbf{C}$ in the reference year by a factor of 2 or more. 
C-14

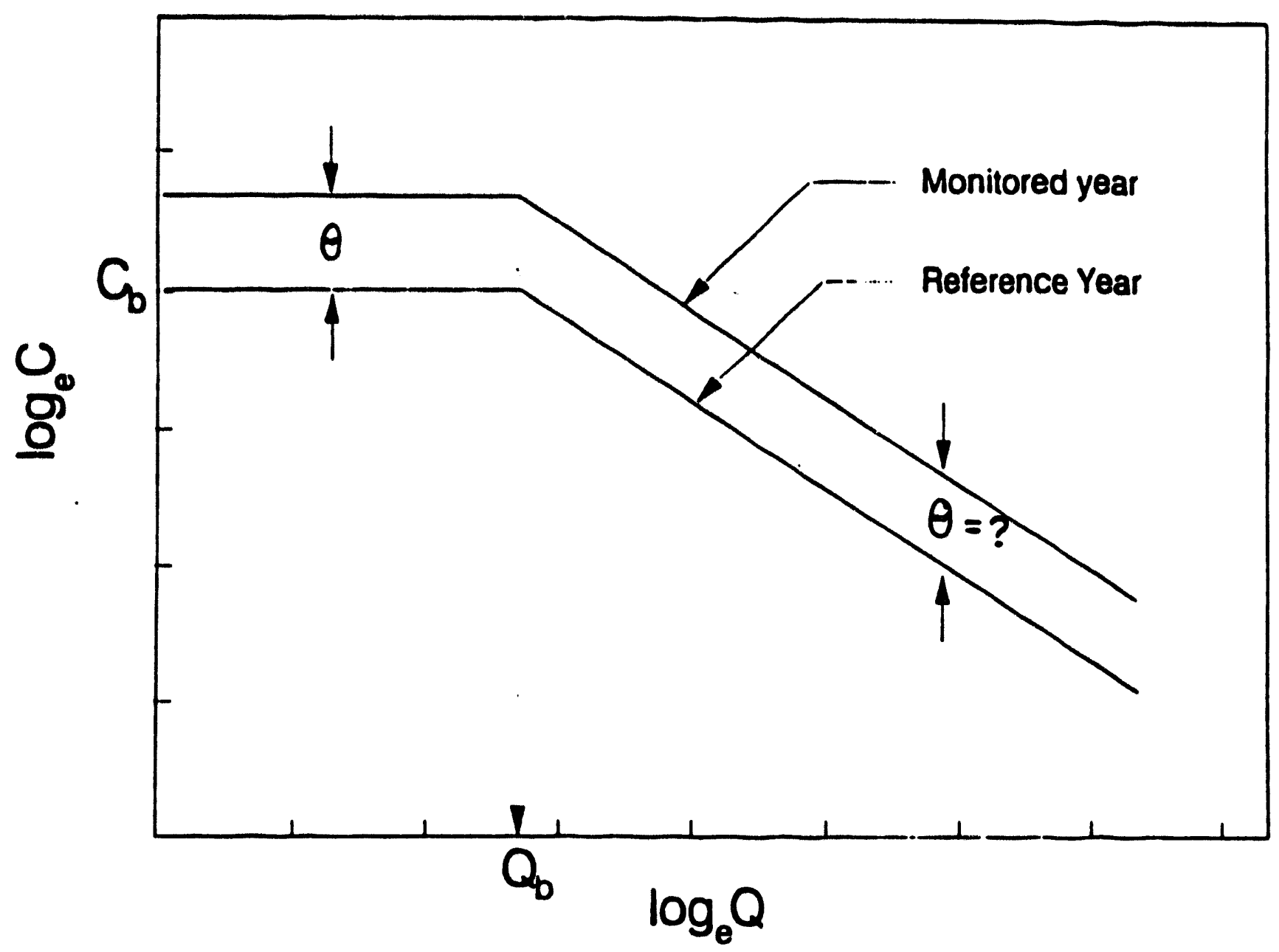

Fig. C.6. A statistical test of a change in concentration level. 


\section{C-15 \\ REFERENCES}

Molroy, L.A., and D.D. Huff, 1985. Annual Reduction of ${ }^{\circ 0}$ Sr Migration From Solid Waste Storage Area 4 to White Oak Creek by Flow Diversion. ORNL/TM-9620, Oak Ridge National Laboratory, Oak Ridge, Tennessee.

Solomon, D.K., J.D. Marsh, I.L. Larsen, D.S. Wickliff, R.B. Clapp, 1991. Transport of Contaminants During Storms in the White Oak Creek and Melton Branch Watersheds. ORNL/TM-11360, Oak Ridge National Laboratory, Oak Ridge, Tennessee. 


\section{APPENDIX D}

\section{CHEMICAL OF CONCERN SELECTION CRITERIA}


Table D.1. Federal drinkins water MCLs and MCLGs

(all units in ma/h unless otherwise noted)

\begin{tabular}{|c|c|c|c|c|c|}
\hline Chemical & $\begin{array}{c}\text { MCL: } \\
\$ 141.11\end{array}$ & $\begin{array}{l}\text { Proposed } \\
\text { MCL }\end{array}$ & $\begin{array}{c}\text { MCL } \\
\$ 141.60 \\
\$ 141.61 \\
\$ 141.62 \\
\end{array}$ & $\begin{array}{l}\text { MCLG } \\
\$ 141.50 \\
\end{array}$ & $\begin{array}{l}\text { Proposed } \\
\text { MCLG }\end{array}$ \\
\hline Acrylamide & - & -4 & - & $\mathbf{0}$ & \\
\hline Adipates [Di(ethylhexyl)adipate] & - & $0.5^{e}$ & & & $0.5^{e}$ \\
\hline Alachlor & - & - & 0.002 & $\mathbf{0}$ & - \\
\hline Aldicarb & - & - & 0.003 & 0.001 & - \\
\hline Aldicarb sulfoxide & - & - & 0.004 & 0.001 & - \\
\hline Aldicarb sulfone & - & - & 0.004 & 0.001 & - \\
\hline Antimony & - & $0.01 / 0.005$ & $0.006^{e}$ & $0.006^{e}$ & $0.003^{2}$ \\
\hline $\begin{array}{l}\text { Adjusted gross alpha emitters } \\
\text { (excluding Ra-226, U, and Rn-222 }\end{array}$ & - & 15 pCi/L' & - & - & $\boldsymbol{\sigma}$ \\
\hline Arsenic & 0.05 & - & - & - & - \\
\hline Atrazine & - & - & 0.003 & 0.003 & - \\
\hline Barium & 1.0 & - & 2.0 & 2.0 & - \\
\hline Benzene & - & - & 0.005 & $\mathbf{0}$ & - \\
\hline Beryllium & - & $0.001^{e}$ & $0.004^{e}$ & 0.04 & $\sigma$ \\
\hline $\begin{array}{l}\text { Bets and photon emitters } \\
\text { (excluding RA-228) }\end{array}$ & - & 4 mrem/ede/y & - & - & $\sigma$ \\
\hline Cadmium & 0.010 & - & 0.005 & 0.005 & - \\
\hline Carbofuran & - & - & 0.04 & 0.04 & - \\
\hline
\end{tabular}


Table D.1 (comtinued)

\begin{tabular}{|c|c|c|c|c|c|}
\hline Chemical & $\begin{array}{c}\text { MCL: } \\
\$ 141.11 \\
\end{array}$ & $\begin{array}{l}\text { Proposed } \\
\text { MCL } \\
\end{array}$ & $\begin{array}{c}\text { MCL } \\
\$ 141.60 \\
\$ 141.61 \\
\$ 141.62 \\
\end{array}$ & $\begin{array}{l}\text { MCLOE } \\
\$ 141.50\end{array}$ & $\begin{array}{l}\text { Proposed } \\
\text { MCLO }\end{array}$ \\
\hline Carbon tetrachloride & - & - & 0.005 & $\mathbf{0}$ & - \\
\hline Chlordane & - & - & 0.002 & $\mathbf{0}$ & - \\
\hline Chlorobenzene & - & - & - & - & - \\
\hline Chromium & 0.05 & - & 0.1 & 0.1 & - \\
\hline Copper & s & - & - & 1.3 & - \\
\hline Cyanide & - & $0.2^{e}$ & $0.2^{*}$ & $0.2^{\circ}$ & $0.2^{e}$ \\
\hline 2,4-D & - & - & 0.07 & 0.07 & - \\
\hline Dalapon & - & $0.2^{e}$ & $0.2^{e}$ & $0.2^{e}$ & $0.2^{*}$ \\
\hline Dibromochloropropane (DBCP) & - & - & 0.0002 & $\mathbf{0}$ & - \\
\hline m-Dichlorobenzene & - & - & 0.6 & 0.6 & - \\
\hline o-Dichlorobenzene & $\cdot$ & - & 0.6 & 0.6 & - \\
\hline p-dichlorobenzene & - & - & 0.075 & 0.075 & - \\
\hline 1,2-Dichloroethane & - & - & 0.005 & $\mathbf{0}$ & - \\
\hline 1,1-Dichloroethylene & - & - & 0.007 & 0.007 & - \\
\hline cis-1,2-Dichloroethylene & - & - & 0.07 & 0.07 & - \\
\hline trans-1,2-Dichloroethylene & - & - & 0.1 & 0.1 & - \\
\hline $\begin{array}{l}\text { Dichloromethane } \\
\text { (Methylene chloride) }\end{array}$ & - & $0.005^{\circ}$ & 0.005 & $\boldsymbol{\sigma}$ & - \\
\hline Di(2-ethylhexyl)adipate & - & $0.5^{*}$ & $0.4^{\circ}$ & $0.4^{\circ}$ & $0.5^{\circ}$ \\
\hline Di(2-ethylhexyl)pthalate & - & 0.004 & $0.006^{\circ}$ & $\sigma$ & $\boldsymbol{\sigma}$ \\
\hline
\end{tabular}




\section{Tablé D.1 (comtinued)}

\begin{tabular}{|c|c|c|c|c|c|}
\hline Chemical & $\begin{array}{c}\text { MCLe } \\
\$ 141.11 \\
\end{array}$ & $\begin{array}{c}\text { Proposed } \\
\text { MCL } \\
\end{array}$ & $\begin{array}{c}\text { MCL } \\
\$ 141.60 \\
\$ 141.61 \\
\$ 141.62 \\
\end{array}$ & $\begin{array}{l}\text { MCLOF } \\
3141.50 \\
\end{array}$ & $\begin{array}{c}\text { Proposed } \\
\text { MCLG }\end{array}$ \\
\hline Di(ethylhexyl)pthalate & - & 0.004 & - & - & $\sigma$ \\
\hline 1,2-Dichloropropane & - & - & 0.005 & $\mathbf{0}$ & - \\
\hline Dinoseb & - & 0.007 & $0.007^{e}$ & $0.007^{e}$ & 0.007 \\
\hline Diquat & - & $0.02^{*}$ & 0.02 & $0.02^{\circ}$ & $0.02^{\circ}$ \\
\hline p-Dioxane & - & - & - & - & - \\
\hline Endothall & - & $0.1^{\circ}$ & $0.1^{\circ}$ & $0.1^{*}$ & $0.1^{\circ}$ \\
\hline Endrin & - & 0.002 & $0.002^{\circ}$ & $0.002^{e}$ & 0.002 \\
\hline Epichlorohydrin & - & $d$ & - & o & - \\
\hline Ethylbenzene & - & - & 0.7 & 0.7 & - \\
\hline Ethylene dibromide (EDB) & - & - & $5.00 \mathrm{E}-05$ & $\mathbf{0}$ & - \\
\hline Ethylene glycol & - & - & - & - & - \\
\hline Flouride & - & - & 4 & 4 & - \\
\hline Glyphosate & - & $0.7^{\circ}$ & $0.7^{\circ}$ & $0.7^{e}$ & $0.7^{e}$ \\
\hline Heptaclor & - & - & 0.0004 & $\mathbf{0}$ & - \\
\hline Heptaclor epoxide & - & - & 0.0002 & $\mathbf{0}$ & - \\
\hline Hexachlorobenzene & - & $0.001^{e}$ & $0.001^{\circ}$ & $\sigma$ & $\boldsymbol{\sigma}$ \\
\hline Hexachlorocyclopentadiene & $\cdot$ & $0.05^{\circ}$ & $0.05^{e}$ & $0.05^{\circ}$ & $0.05^{\circ}$ \\
\hline n-Hexane & - & - & - & - & - \\
\hline Lead & 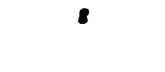 & - & - & $\mathbf{0}$ & - \\
\hline Lindane & 0.0002 & - & - & 0.0002 & - \\
\hline
\end{tabular}


Table D.1 (continesed)

\begin{tabular}{|c|c|c|c|c|c|}
\hline Chemical & $\begin{array}{c}\text { MCL: } \\
\$ 141.11 \\
\end{array}$ & $\begin{array}{c}\text { Proposed } \\
\text { MCL } \\
\end{array}$ & $\begin{array}{c}\text { MCL } \\
\$ 141.60^{\circ} \\
\$ 141.61 \\
\$ 141.62 \\
\end{array}$ & $\begin{array}{l}\text { MCLOe } \\
\$ 141.50 \\
\end{array}$ & $\begin{array}{l}\text { Proposed } \\
\text { MCLO }\end{array}$ \\
\hline Mercury & 0.002 & - & - & 0.002 & - \\
\hline Methoxychlor & 0.01 & - & 0.04 & 0.04 & - \\
\hline Methyl ethyl Ketone & - & - & - & - & - \\
\hline Monochlorobenzene & - & - & 0.1 & 0.1 & - \\
\hline Nickel & - & $0.1^{\circ}$ & $0.1^{e}$ & $0.1^{*}$ & $0.1^{e}$ \\
\hline Nitrate (as N) & 10 & - & 10 & 10 & - \\
\hline Nitrite (as N) & 1 & - & 1 & 1 & - \\
\hline Total Nitrate and Nitrite (as N) & 10 & - & 10 & 10 & - \\
\hline Oxamyl (Vydate) & - & $0.2^{*}$ & $0.2^{*}$ & $0.2^{2}$ & $0.2^{\circ}$ \\
\hline $\begin{array}{l}\text { PAHs } \\
\text { Benzo(a)pyrene }\end{array}$ & - & $0.0002^{*}$ & $0.002^{e}$ & $\boldsymbol{\sigma}$ & $\boldsymbol{\sigma}$ \\
\hline Benzo(a)anthracene & - & $0.0001^{n}$ & - & - & $\infty^{\infty}$ \\
\hline Benzo(b)fluoranthene & - & $0.0002^{n}$ & - & - & o \\
\hline Benzo(k)flouranthene & - & $0.0002^{n}$ & - & & $0^{n}$ \\
\hline Chryseme & - & $0.0002^{4}$ & - & - & $0^{*}$ \\
\hline Dibenz(a,h)anthracene & - & $0.0003^{n}$ & - & & on \\
\hline Indenopyrene & - & $0.0004^{4}$ & - & - & $0^{\infty}$ \\
\hline PCBs & - & - & 0.0005 & $\mathbf{0}$ & - \\
\hline Pentachlorophenol & - & - & 0.001 & $\mathbf{0}$ & - \\
\hline Picloran & - & $0.5^{\circ}$ & $0.5^{5}$ & $0.5^{e}$ & $0.5^{e}$ \\
\hline
\end{tabular}


'Table D.1 (continued)

\begin{tabular}{|c|c|c|c|c|c|}
\hline Chemical & $\begin{array}{c}\text { MCL: } \\
\$ 141.11\end{array}$ & $\begin{array}{l}\text { Proposed } \\
\text { MCL }\end{array}$ & $\begin{array}{c}\text { MCL } \\
\$ 141.60 \\
\$ 141.61 \\
\$ 141.62\end{array}$ & $\begin{array}{l}\text { MCLOC } \\
\$ 141.50\end{array}$ & $\begin{array}{c}\text { Proposed } \\
\text { MCLG }\end{array}$ \\
\hline Redium-226 & - & $20 \mathrm{pCi} / \mathrm{L}$ & - & - & $\boldsymbol{\sigma}$ \\
\hline Redium-228 & - & $20 \mathrm{pCi} / \mathrm{J}$ & - & - & $\boldsymbol{\sigma}$ \\
\hline Radon-222 & - & $300 \mathrm{pCi} / \mathrm{L}^{\prime}$ & - & - & $\boldsymbol{\sigma}$ \\
\hline Selenium & 0.01 & - & 0.05 & 0.05 & - \\
\hline Silver & 0.05 & - & - & - & - \\
\hline Simazine & - & $0.001^{e}$ & $0.004^{e}$ & $0.004^{e}$ & $0.001^{e}$ \\
\hline Sulfate & - & $400 / 500$ & Deferred & Deferred & $400 / 500$ \\
\hline Styrene & - & - & 0.1 & 0.1 & - \\
\hline 2,3,7,8-TCDD & - & 5E-08 & $3 E-08$ & $\boldsymbol{\sigma}$ & o \\
\hline Tetrachloroethylene & - & - & 0.005 & $\mathbf{0}$ & - \\
\hline Thallium & - & $0.002 / 0.001^{e}$ & $0.002^{e}$ & 0.005 & $0.0005^{\circ}$ \\
\hline Toulene & - & - & 1.0 & 1.0 & - \\
\hline Toxaphene & 0.005 & - & 0.003 & $\mathbf{0}$ & - \\
\hline 2,4,5-TP (Silvex) & 0.01 & - & 0.05 & 0.05 & - \\
\hline 1,2,4-Trichlorobenzene & - & 0.009 & $0.07^{\circ}$ & $0.07^{\circ}$ & 0.009 \\
\hline 1,1,1-Trichloroethane & - & - & 0.2 & 0.2 & - \\
\hline 1,1,2-Trichloroethane & - & $0.005^{e}$ & $0.005^{e}$ & $0.003^{e}$ & $0.003^{\circ}$ \\
\hline Trichloroethylene (TCE) & - & - & 0.005 & $\mathbf{0}$ & - \\
\hline
\end{tabular}


Table D.1 (comtinued)

\begin{tabular}{|c|c|c|c|c|c|}
\hline Chemical & $\begin{array}{c}\text { MCL } \\
\text { \$141.11 }\end{array}$ & $\begin{array}{c}\text { Proposed } \\
\text { MCL }\end{array}$ & $\begin{array}{l}\mathrm{MCL} \\
8141.6 \% \\
8141.61 \\
8141.62 \\
\end{array}$ & $\begin{array}{l}\text { MCLa } \\
\$ 141.50\end{array}$ & $\begin{array}{l}\text { Proposed } \\
\text { MCLO }\end{array}$ \\
\hline $\begin{array}{l}\text { Total trihalomethenes (TTHM) } \\
\text { (chloroform, bromoform, bromo- } \\
\text { dichloromethme, } \\
\text { dibromochloromethene) }\end{array}$ & 0.1 & - & - & - & - \\
\hline Uranium & - & $\begin{array}{c}0.02(20 \mu g / L) \\
30 \mathrm{pCi} / \mathcal{L}\end{array}$ & - & - & $\sigma$ \\
\hline Vinyi chloride & - & - & 0.002 & $\mathbf{0}$ & - \\
\hline Xylenes & - & - & 10 & 10 & - \\
\hline
\end{tabular}

-40 CFR 5141.11. Maximum Contaminant Levels for Inorganic Chemicals.

40 CFR 8141.60. National Revised Primary Drinking Water Regulations: Maximum Contaminant Levels.

'40 CFR 8141.50. Maximum Contaminant Level Goals for Organic Contaminants.

Treatment tochnique requirement limits the amount of the chemical which is used to treat drinking water.

'Final Rule, National Primary Drinking Water Regulations; Synthetic Organic Chemicals and Inorganic Chemicals. 57 FR 31776 (7-17-92).

Proposed Rule. National Primary Drinking Water Regulations, Radionuclides. 56 FR 33050 (7-18-91).

MCL deleted (use treatment instead) 56 FR 26460 (June 7, 1991). Effective date: 12-7-92.

hProposed Rule, National Primary and Secondary Drinking Water Regulations: Symthetic Organic Chemicals and Inorganic Chemicals. 55 FR 30370 (July 25, 1990). 


\begin{tabular}{|c|c|c|c|c|c|c|c|c|c|c|}
\hline \multirow[b]{2}{*}{ Chemical } & \multirow[b]{2}{*}{ CASRN } & \multicolumn{3}{|c|}{ Ingestion (mg/L) } & \multicolumn{3}{|c|}{ Inhalation (mg/L) } & \multicolumn{3}{|c|}{$\begin{array}{c}\text { Ingestion + Inhalation } \\
(m g h)^{b}\end{array}$} \\
\hline & & 10 & 10 & $\mathbf{m}=1$ & 10 & 100 & $m=1$ & 10 & 106 & $m=1$ \\
\hline ACENAPHTHENE & 83-32-9 & & & $2.2 E+\infty$ & & & & & & \\
\hline ACEPHATE & $30560-19.1$ & $9.8 E-01$ & $9.8 E-03$ & 1.SE-01 & & & & & & \\
\hline ACETALDEHYDE & $75-07-0$ & & & & & & 2.5E-02 & & & \\
\hline ACETONE & $67-64-1$ & & & $3.7 E+\infty$ & & & & & & \\
\hline ACETONE CYANOHYDREN & 75.26 .5 & & & $2.6 E+\infty$ & & & & & & \\
\hline ACETONITRULE & $75-05.8$ & & & $2.2 E-01$ & & & & & & \\
\hline ACETOPHENONE & $99-86-2$ & & & $3.7 E+\infty$ & & & $5.6 \mathrm{E}-05$ & & & 5.6E-05 \\
\hline ACROLIN & $107-02-8$ & & & $7.3 \mathrm{E}-01$ & & & $5.6 E-05$ & & & $5.6 E-05$ \\
\hline ACRYLAMADE & $79-06-1$ & $1.9 E-03$ & $1.9 E_{-0 S}$ & 7.3E-03 & & & & & & \\
\hline ACRYUC ACID & $79-10-7$ & & & $2.9 E+\infty$ & & & & & & \\
\hline ACRYLONITRILE & 107-13-1 & $1.6 \mathrm{E}-02$ & $1.6 E-04$ & & 9.5E-03 & 9.5E-05 & 5.6E-03 & $5.9 E-03$ & S.9E-0S & \\
\hline ALACHLOR & $15972-60.8$ & I.1E-01 & 1.1E-03 & $3.7 \mathrm{E}-01$ & & & & & & \\
\hline ALAR & $1596-84-5$ & & & $5.5 E+\infty$ & & & & & & \\
\hline ALDICARB & $116-06-3$ & & & 7.3E-03 & & & & & & \\
\hline ALDRIN & $309-00-2$ & $5.0 E-04$ & $5.0 E-06$ & 1.1E-03 & & & & & & \\
\hline AuY & $74223-64-6$ & & & $9.1 E+\infty$ & & & & & & \\
\hline ALLY ALCOHOL & $107.18-6$ & & & $1.8 E-01$ & & & & & & \\
\hline ALYYL CHLORJDE & $107-05-1$ & & & $1.8 E+\infty$ & & & 2.8E-03 & & & 2.8E-03 \\
\hline ALUMNUM PHOSPHIDE & 20059-73-8 & & & $1.5 E-02$ & & & & & & \\
\hline AMDRO & $67485-29-4$ & & & $1.1 E-02$ & & & & & & \\
\hline AMETRYN & $834-12-8$ & & & 3.3E-01 & & & & & & \\
\hline
\end{tabular}


Table D.2. (continued)

\begin{tabular}{|c|c|c|c|c|c|c|c|c|c|c|}
\hline \multirow[b]{2}{*}{ Chemical } & \multirow[b]{2}{*}{ CASRN } & \multicolumn{3}{|c|}{ Ingestion (mag) } & \multicolumn{3}{|c|}{ Inhalation (mg/L) } & \multicolumn{3}{|c|}{$\begin{array}{c}\text { Ingeation + Inhalation } \\
(m g / L)^{b}\end{array}$} \\
\hline & & 100 & 10 & $\mathbf{m = 1}$ & مصו & 10 & $w=1$ & 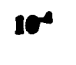 & 10 & m=1 \\
\hline AMINOFHENOL, M- & $591-27.5$ & & & $2.6 E+\infty$ & & & & & & \\
\hline AMANOPYRIDINE, 4- & 504.24 .5 & & & 7.3E-04 & & & & & & \\
\hline AMatrez & $33009-61-1$ & & & 9.1E-02 & & & & & & \\
\hline AMMONIA & $7664+1.7$ & & & & & & & & & \\
\hline AMMONIUM SULFAMATE & $m 73-06-0$ & & & $7.3 E+\infty$ & & & & & & \\
\hline ANIUNE & 62.53.3 & & & & & & & & & \\
\hline ANTHRACENE & 120.12 .7 & & & $1.1 E+01$ & & & & & & \\
\hline ANTIMONY (METALUC) & $7400.36-0$ & & & $1.5 \mathrm{E}-02$ & & & & & & \\
\hline ANTMONY PENTOXIDE & $1314-60.9$ & & & $1.0 E-02$ & & & & & & \\
\hline ANTIMONY POTASSIUM TARTRATE & $300-61-0$ & & & 3.3E-02 & & & & & & \\
\hline ANTIMONY TETROXIDE & $1332-81-6$ & & & $1.5 E-02$ & & & & & & \\
\hline ANTIMONY TRJOXIDE & $1309-64-4$ & & & $1.5 E-02$ & & & & & & \\
\hline APOLO & $74115-24-5$ & & & 4.7E-01 & & & & & & \\
\hline ARAMITE & 140.57 .8 & 3.4E-01 & 3.4E-03 & $1.8 E+\infty$ & & & & & & \\
\hline AROCLOR-1016" & $12674-11-2$ & $1.1 \mathrm{E}-03$ & $1.1 \mathrm{E}-05$ & & & & & & & \\
\hline AROCLOR-1221" & $11104-28-2$ & $1.1 E-03$ & 1.1E-05 & & & & & & & \\
\hline AROCLOR-1232 & $11141-16-5$ & $1.1 E-03$ & $1.1 E-05$ & & & & & & & \\
\hline AROCLOR-1242 & $53469-21-9$ & $1.1 \mathrm{E}-03$ & 1.IE-OS & & & & & & & \\
\hline AROCLOR-1248" & $12672-29-6$ & $1.1 \mathrm{E}-03$ & $1.1 \mathrm{E}-05$ & & & & & & & \\
\hline AROCLOR-1254 & $11097-69.1$ & 1.1E-03 & 1.1E-0s & & & & & & & \\
\hline AROCLOR-:Z260" & $11096-82.5$ & $1.1 E-03$ & 1.1E-0S & & & & & & & \\
\hline ARSENIC, INORGANIC & $7400-38-2$ & & & $1.1 E-02$ & & & & & & \\
\hline ASSURE & $76578-14-8$ & & & $3.3 \mathrm{E}-01$ & & & & & & \\
\hline
\end{tabular}


Table D.2. (continued)

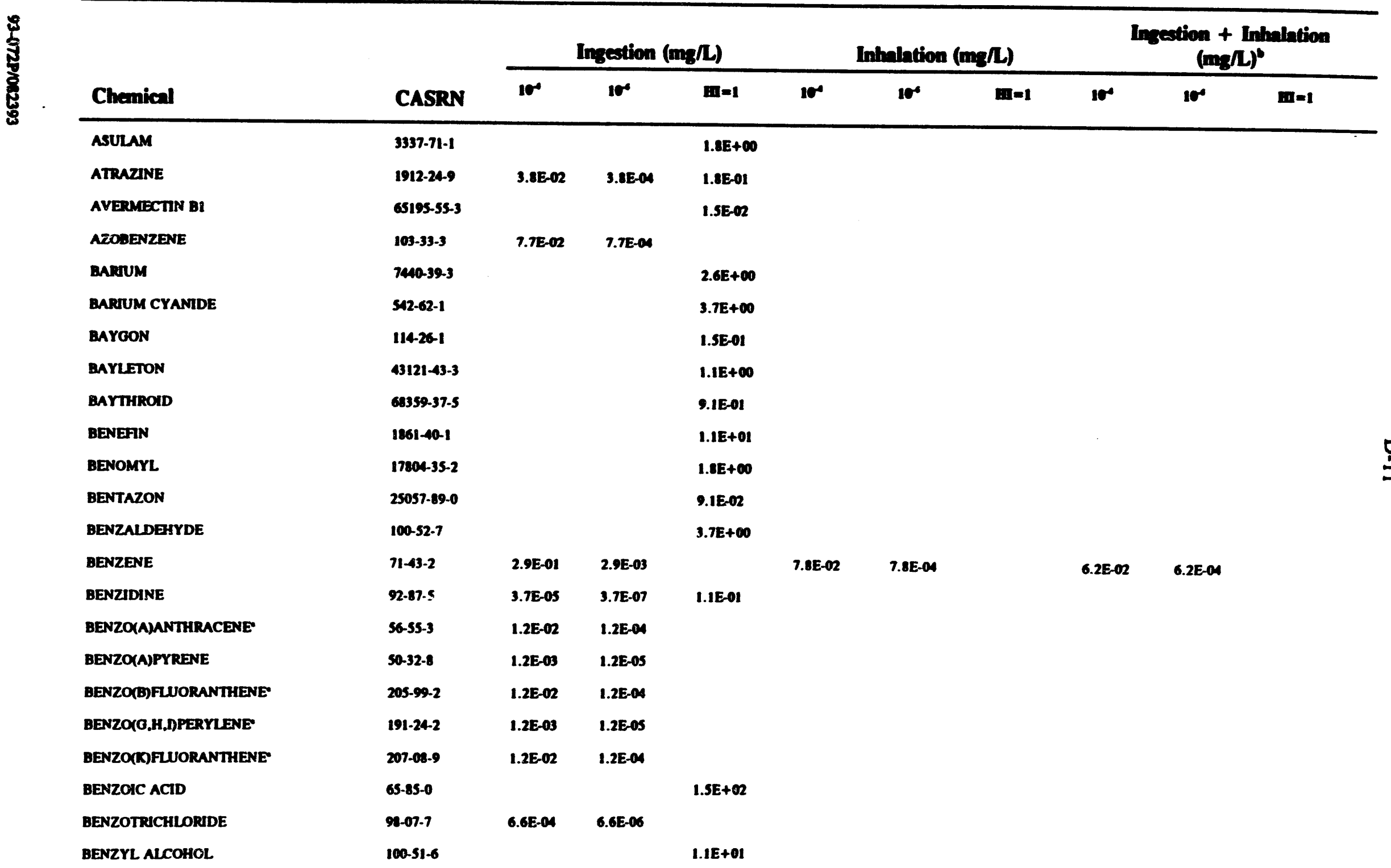


Table D.2. (continned)

\begin{tabular}{|c|c|c|c|c|c|c|c|c|c|c|c|}
\hline \multirow[b]{2}{*}{ Chemical } & \multirow[b]{2}{*}{ CASRN } & \multicolumn{3}{|c|}{ Ingestion (mg/L) } & \multicolumn{3}{|c|}{ Inhalation (man) } & \multicolumn{3}{|c|}{$\begin{array}{c}\text { Investion + Inhalation } \\
(\mathrm{mg} / L)^{\circ}\end{array}$} & \\
\hline & & 10 & 10 & $m=1$ & 10 & مص1 & $m-1$ & مיו & 10 & $=1$ & \\
\hline BENZYL CHLORDE & $100-4.7$ & $5.05-02$ & $5.05-04$ & & & & & & & & \\
\hline BERYUUM & 1940-11.7 & $2.05-03$ & $2.06-05$ & 1.0E-01 & & & & & & & \\
\hline BIDRN & $141-66-2$ & & & $3.7 E-03$ & & & & & & & \\
\hline DAPHENTHREN & $22657-04.3$ & & & S.SE-01 & & & & & & & \\
\hline GPHENYL, 1.1. & 92-52-4 & & & $1.8 E+\infty$ & & & & & & & \\
\hline MSS(2-CHLOROETHYLIETHER & $111-4+4$ & 7.7E-03 & $7.7 \mathrm{E}-0 \mathrm{~S}$ & & $2.18-03$ & 2.1E-05 & & $1.65-03$ & $1.6 E-08$ & & \\
\hline MS(2-ETHYLHEXYL)HTHALATE & $117-81.7$ & 6.1E-01 & $6.1 E-03$ & $7.3 E-01$ & & & & & & & \\
\hline BSSCHLOROMETHYLUETHER & $542-88-1$ & $3.9 E-05$ & $3.9 E-07$ & & $1.06-05$ & $1.0 E-07$ & & $8.1 E-06$ & $8.1 E-08$ & & \\
\hline BSPHENOLA & 2005-7 & & & $1.8 E+\infty$ & & & & & & & \\
\hline BORON TRARUORADE & $7637-07-2$ & & & & & & & & & & $\varphi_{1}$ \\
\hline BORON & $7460-12-8$ & & & $3.3 E+\infty$ & & & & & & & $\bar{N}$ \\
\hline BROMODICHLOROMETHANE & $75-27-4$ & $6.6 E-02$ & $6.6 E-04$ & $7.3 E-01$ & & & & & & & \\
\hline BROMOPORM & $75-25-2$ & $1.1 E+\infty$ & $1.1 E-02$ & 7.3E-01 & & & & & & & \\
\hline BROMOMETHANE & $74-83-9$ & & & $5.1 E_{-02}$ & & & $1.4 \mathrm{E}-02$ & & & $1.1 E-02$ & \\
\hline BROMOPHOS & $2104-96-3$ & & & $1.8 E-01$ & & & & & & & \\
\hline BROMOXYMIL & 1699-24-5 & & & 7.3E-01 & & & & & & & \\
\hline DROMOXYNIL OCTANOATE & $1689.99-2$ & & & 7.3E-01 & & & & & & & \\
\hline BUTADIENE,1.3- & $106-99-0$ & & & & $1.3 E-03$ & $1.3 \mathrm{E}-0 \mathrm{~S}$ & & & & & \\
\hline BUTANOL N. & $71 \cdot 36-3$ & & & $3.7 E+\infty$ & & & & & & & \\
\hline BUTYL BENZYL PHTHLATE & $85-68-7$ & & & $7.3 E+\infty$ & & & & & & & \\
\hline DUTYLATE & $2000-11 \cdot 5$ & & & $1.8 E+\infty$ & & & & & & & \\
\hline BUTYLPHTHALYL BUTYLLIYCOLATE & es-70-1 & & & $3.7 E+01$ & & & & & & & \\
\hline CACODYUC ACID & 75.60 .5 & & & $1.1 E-01$ & & & & & & & \\
\hline , & & & - & & & & & & $\cdot$ & · & \\
\hline
\end{tabular}


- Table D.2. (comtinened)

\begin{tabular}{|c|c|c|c|c|c|c|c|c|c|c|}
\hline \multirow[b]{2}{*}{ Chemical } & \multirow[b]{2}{*}{ CASRN } & \multicolumn{3}{|c|}{ Ingestion (mg/L) } & \multicolumn{3}{|c|}{ Intulation $(\mathrm{mg} / \mathrm{L})$} & \multicolumn{3}{|c|}{$\begin{array}{c}\text { Investion + Imbalation } \\
(m g h)^{\circ}\end{array}$} \\
\hline & & 104 & 10 & $m=1$ & مe & 100 & $m=1$ & 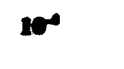 & en & $\mathbf{m = 1}$ \\
\hline CADITUM & $7400-43-9$ & & & $1.85-22$ & & & & & & \\
\hline CALCTUM CYANIDE & $592-01-8$ & & & $1.5 E+\infty$ & & & & & & \\
\hline CAPAOLACTAM & $105-60.2$ & & & $1.8 E+01$ & & & & & & \\
\hline CAPTAFOL & $2425-06-1$ & $9.9 E-01$ & 9.9E-03 & $7.3 E-02$ & & & & & & \\
\hline CAPTAN & $133-06-2$ & $2.4 E+\infty$ & 2.4E-02 & $4.7 E+\infty$ & & & & & & \\
\hline CARBARYL & $63-25-2$ & & & $3.7 E+\infty$ & & & & & & \\
\hline CARBAZOLE & $26.74-8$ & 4.3E-01 & 4.3E-03 & & & & & & & \\
\hline CARBOFURAN & $1563.66-2$ & & & $1.8 E-01$ & & & & & & \\
\hline CARBON DLSULAIDE & $75-15-0$ & & & $3 . T E+\infty$ & & & $2.8 E-2$ & & & 2.8E-02 \\
\hline CAREON TETRACHLORADE & s6-23-5 & $6.6 E-02$ & $6.6 E-04$ & $2.6 E-02$ & $4.3 E-02$ & $4.3 \mathrm{E}-04$ & & $2.65-62$ & $2.6 E-04$ & \\
\hline CARBOSULFAN & $55285-14-8$ & & & 3.TE-01 & & & & & & \\
\hline CARBOXXN & $5234-68-4$ & & & $3.7 E+\infty$ & & & & & & \\
\hline CHLORAL & $75-87-6$ & & & $7.3 \mathrm{E}-02$ & & & & & & \\
\hline CHLORAMBEN & $133.90-4$ & & & S.SE-01 & & & & & & \\
\hline CHLORANIL & $118-75-2$ & 2.1E-02 & 2.1E-04 & & & & & & & \\
\hline CHLORANIUNE, P- & $106-17-8$ & & & 1.5E-OI & & & & & & \\
\hline CHLORDANE & $57.74-9$ & 6.6E-03 & $6.6 E-05$ & 2.2E-03 & & & & & & \\
\hline CHLORMURON-ENTYL & $90982-32-4$ & & & 1.3E-01 & & & & & & \\
\hline CHLORANE CYANIDE & so6-77-4 & & & $1.8 E+\infty$ & & & & & & \\
\hline CHLORNE DrOXIDE & 100019-04-4 & & & & & & & & & \\
\hline CHLORO-1,3-BUTADIENE, 2. & 126.928 & & & $7.3 \mathrm{E}-01$ & & & $1.9 E-02$ & & & $1.9 E-02$ \\
\hline CHLORO-2-METHYLANIUNEHCL, 4. & 3165-93-3 & $1.9 E-02$ & $1.9 E-04$ & & & & & & & \\
\hline CHLORO-2-METHYYANUINE, 4 & $95-69-2$ & $1.5 E-02$ & 1.SE-OA & & & & & & & \\
\hline
\end{tabular}


Talble D.2. (condineded)

\begin{tabular}{|c|c|c|c|c|c|c|c|c|c|c|c|}
\hline \multirow[b]{2}{*}{ Chemical } & \multirow[b]{2}{*}{ CASRN } & \multicolumn{3}{|c|}{ Inpestion (mg/L) } & \multicolumn{3}{|c|}{ Intalation (ma/L) } & \multicolumn{3}{|c|}{ 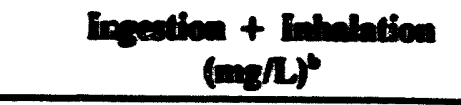 } & \\
\hline & & 10 & 10 & $\mathbf{m = 1}$ & & 10 & $m-1$ & مص & en & $\mathbf{m = 1}$ & \\
\hline CHLOROACETC ACID & 29-11-8 & & & $7.35-02$ & & & & & & & \\
\hline CHLOEDeENZENE & $100-90.7$ & & & 7.3E-01 & & & $5.65-02$ & & & $5.2 E-62$ & \\
\hline CHLoRosenzmate & $310-15-6$ & & & 7.3E-01 & & & & & & & \\
\hline CHLOROBENZOAC ACTD. P. & $74-11-3$ & & & $7.3 E+\infty$ & & & & & & & \\
\hline CHLOROBENZOTRAFWONDE, 4 - & 20-56-6 & & & 7.3E-01 & & & & & & & \\
\hline CHLOROBUTANE, I- & $109-69-3$ & & & $1.5 E+01$ & & & & & & & \\
\hline CHLORODRROMOETHANE & $73506-94-2$ & $1.0 E-01$ & $1.0 E-03$ & & & & & & & & \\
\hline CHLONOFORM & $67-66-3$ & $1.4 E+\infty$ & $1.4 E-02$ & $3.7 E-01$ & $2.8 E-02$ & 2.AE-04 & & $2 . \pi E-2$ & 2.TE-A & & \\
\hline CHLONOHSOPROPYL ETHER, DESR- & $100-60.1$ & $1.2 E-01$ & $1.2 E-03$ & $1.5 E+\infty$ & 6.5E-02 & $6.5 E-04$ & & $4.2 E-02$ & $4.2 \mathrm{E}-04$ & & \\
\hline CHLOROMETHANE & $74-87.3$ & 6.6E-01 & $6.65-03$ & & $3.6 E-01$ & $3.6 E-03$ & & 2.3E-01 & $2.3 E-63$ & & $\varphi$ \\
\hline CHLORONAPHTHALENE, BETA. & $91-58-7$ & & & $2.9 E+\infty$ & & & & & & & $\bar{A}$ \\
\hline CHLORONITROBENZENE, O- & 82-73-3 & 3.4E-01 & 3.4E-03 & & & & & & & & \\
\hline CHLORONITROBENZENE, P. & $121-73-3$ & 4.7E-01 & 4.7E-03 & & & & & & & & \\
\hline CHLOROPHENOL, 2 - & $95-57-8$ & & & $1.8 E-01$ & & & & & & & \\
\hline CHLOROPROPANE, 2 - & 75.29 .6 & & & & & & $2.8 E-01$ & & & & \\
\hline CHLOROTHALONL & 1097-45-6 & 7.7E-01 & $7.7 E-03$ & S.SE-01 & & & & & & & \\
\hline CHLOROTOLUENE, O. & $95-09-8$ & & & 7.3E-01 & & & & & & & \\
\hline CHLORPROPHAM & $101-21-3$ & & & $7.3 E+\infty$ & & & & & & & \\
\hline CHLORPYRIFOS & $2921-602-2$ & & & 1.1E-01 & & & & & & & \\
\hline CHLORPYRIFOS METHYL & $5592-13-0$ & & & 3.TE-01 & & & & & & & \\
\hline CHLORSULFURON & $60902-72-3$ & & & $1.2 E+\infty$ & & & & & & & \\
\hline CHLORTHOPHOS & $60238-56-4$ & & & $2.9 E-02$ & & & & & & & \\
\hline CHROMUM (m) & $16055-83-1$ & & & $3.7 E+01$ & & & & & & & \\
\hline . & & & • & & & & & & $\bullet$ & - & \\
\hline
\end{tabular}


Tabie D.2. (comained)

\begin{tabular}{|c|c|c|c|c|c|c|c|c|c|c|}
\hline \multirow[b]{2}{*}{ Chemieal } & \multirow[b]{2}{*}{ CASRN } & \multicolumn{3}{|c|}{ Ingestion (mg/L) } & \multicolumn{3}{|c|}{ Intalation (mall) } & \multicolumn{3}{|c|}{$\begin{array}{c}\text { Insestion + Inlmabation } \\
(m, h)^{\circ}\end{array}$} \\
\hline & & 10 & م & $m=1$ & 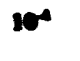 & م & $\mathbf{m}=1$ & مמת & مo & $m=1$ \\
\hline CHRONAUM (VI) & 18san-2ses & & & $1.08-1$ & & & & & & \\
\hline Charsene & 21E-01-9 & $1.2 \mathrm{E}-01$ & $1.2 \mathrm{E}-03$ & & & & & & & \\
\hline COAL TANS & MA & & & & & & & & & \\
\hline CORPER CYANIDE & $\operatorname{sen} 2-3$ & & & $1.85-01$ & & & & & & \\
\hline Cresol, $M$ & $100-394$ & & & $1.8 E+\infty$ & & & & & & \\
\hline Cresol, a & $95-48-7$ & & & $1.9 E+\infty$ & & & & & & \\
\hline Cresol, P. & $100-445$ & & & 1.0E-01 & & & & & & \\
\hline CROTONALDEHYDE & $123-73-9$ & 4.5E-03 & 4.5E-05 & & & & & & & \\
\hline CRYOMenZNNE & $60215-27.8$ & & & $2.7 E-01$ & & & & & & \\
\hline CUMENE & en-22-s & & & $1.5 E+\infty$ & & & $2.55-02$ & & & 2.SE-02 \\
\hline CYANAZZNE & $21725-40-2$ & & & 7.3E-02 & & & & & & \\
\hline CYANIDE (CN-) & $57-12-5$ & & & $7.3 E-01$ & & & & & & \\
\hline CYANOGEN & 460.19 .5 & & & $1.5 E+\infty$ & & & & & & \\
\hline CYANOOEN BROMADE & $5006-6$ & & & $3.3 E+\infty$ & & & & & & \\
\hline CYANOGEN CHLORADE & $506-774$ & & & $1.0 E+\infty$ & & & & & & \\
\hline $\begin{array}{l}\text { CYCLOHEXANE, } \\
\text { 1.2.3.4,5-PENTABROMO-CHLONO }\end{array}$ & 87.24-3 & 3.7E-el & $3.7 \mathrm{E}-03$ & & & & & & & \\
\hline CYCLOHEXANONE & $100-24-1$ & & & $1.0 E+02$ & & & & & & \\
\hline CYCLOHEXYMLANE & 100-91-8 & & & $1.3 E+\infty$ & & & & & & \\
\hline CYHALOTHRAN/CARATE & cocoss-es-8 & & & $1.8 E-01$ & & & & & & \\
\hline CYPERMETHINUN & 52315-07-9 & & & 3.7E-01 & & & & & & \\
\hline DALAPON & $75-99-0$ & & & $1.1 E+\infty$ & & & & & & \\
\hline DCHLOROFHENOXY ACETIC ACID. 2.4 & $94-75-7$ & & & $3 . \pi E-01$ & & & & & & \\
\hline DDD & $72-54-8$ & 3.5E-02 & 3.5E-O4 & & & & & & & \\
\hline
\end{tabular}


Table D.2. (cominimed)

\begin{tabular}{|c|c|c|c|c|c|c|c|c|c|c|c|}
\hline \multirow[b]{2}{*}{ Chemical } & \multirow[b]{2}{*}{ CASRN } & \multicolumn{3}{|c|}{ Inpestion $(\operatorname{meg} / \mathrm{L})$} & \multicolumn{3}{|c|}{ Inhalation $(m, / L)$} & \multicolumn{3}{|c|}{$\begin{array}{c}\text { Insection + Inhalation } \\
(\mathrm{mg} / \mathrm{h})^{6}\end{array}$} & \\
\hline & & 10 & 10 & $m=1$ & 10 & مo & $=1$ & مه & $\omega$ & $m=1$ & \\
\hline DDE & 72-ss-9 & $2.55-02$ & 2.5E-04 & & & & & & & & \\
\hline DDT & sa-2s.3 & $2.55-02$ & $2.5 E-04$ & $1.08-8$ & & & & & & & \\
\hline DECASROMODTHENY ETHER & $1163-19.5$ & & & $3.75-1$ & & & & & & & \\
\hline DEMETON & $\cos -40-3$ & & & $1.95-03$ & & & & & & & \\
\hline DH2-ETHYL HEXYLADIPATE & $103-23-1$ & $7.1 \mathrm{E}+\infty$ & 7.1E-02 & & & & & & & & \\
\hline DINLATE & 2303.164 & 1.4E-01 & 1.AE-03 & & & & & & & & \\
\hline DIAZINON & $333-41.5$ & & & $3.35-62$ & & & & & & & \\
\hline DREENZ(A.H)ANTHRACENE & $53-20-3$ & $1.2 \mathrm{E}-03$ & $1.2 E-05$ & & & & & & & & \\
\hline DLBROMO-.CHLOROPROPANE, 1,2- & $9-12-8$ & $6.1 E_{-03}$ & 6.1E-0S & & & & & & & & \\
\hline DABROMODENZENE, 1.4. & $106-37-6$ & & & $3.7 E-01$ & & & & & & & $\varnothing$ \\
\hline DEDROMOCHLOROMETHANE & $120-18-1$ & $1.06-01$ & $1.06-03$ & 7.3E-11 & & & & & & & $\dot{\sigma}$ \\
\hline DEBROMOETHANE, 1.2- & $106-93-4$ & $1.0 E-04$ & $1.08-06$ & & $3.0 E-03$ & 3.0E-05 & & 9.7E-05 & 9.7E-07 & & \\
\hline DIBROMOMETHANE & $74-95-3$ & & & $3.76-01$ & & & & & & & \\
\hline DABUTYL PHTHALATE & 24.74-2 & & & $3.7 \mathrm{E}+\infty$ & & & & & & & \\
\hline Dicaman & 1918-00.9 & & & $1.1 E+\infty$ & & & & & & & \\
\hline DICHLORO-2-BUTENE, 1,4. & $260+11-0$ & & & & 2.4E-00 & $2.4 E-06$ & & & & & \\
\hline DICHLOROBENZENE, 1.2- & 95.-5a-1 & & & $3.3 E+\infty$ & & & S.CE-01 & & & 4.8E-OI & \\
\hline DICHLOROBENZENE, 1.4. & $106-46.7$ & 3.JE-01 & 3.5E-03 & & & & $1.9 E+\infty$ & & & & \\
\hline DICHLOROBENZIDINE, 3.3. & $91-94-1$ & $1.95-02$ & $1.9 E-00$ & & & & & & & & \\
\hline DHCHLORODIFWOROMETHUNE & 75-71-4 & & & $7.3 E+\infty$ & & & S.CE-O1 & & & S.2E-01 & \\
\hline DICHLOROETHANE, 1.1. & 75-34-3 & & & $3.7 E+\infty$ & & & $1.4 E+\infty$ & & & $1.0 E+\infty$ & \\
\hline DKCHLOROETHANE, 1.2. & $107-06-2$ & Q.4E-02 & $9.4 E-04$ & & 2.5E-02 & $2.5 E-04$ & & $2.0 E-02$ & $2.0 E-04$ & & \\
\hline DACHLOROETHYLENE, 1.1- & 75-35-4 & 1.4E-02 & 1.4E-04 & $3.35-01$ & $1.9 E-03$ & $1.95-0 S$ & & $1.7 E-03$ & 1.TE-OS & & \\
\hline . & & & - & & & & & & - & - & \\
\hline
\end{tabular}


Table D.2. (comtinued)

\begin{tabular}{|c|c|c|c|c|c|c|c|c|c|c|}
\hline \multirow[b]{2}{*}{ Chemical } & \multirow[b]{2}{*}{ CASRN } & \multicolumn{3}{|c|}{ Ingestion (mg/L) } & \multicolumn{3}{|c|}{ Inhlation $(m g / L)$} & \multicolumn{3}{|c|}{$\begin{array}{c}\text { Investion + Inlablation } \\
(m, / L)^{p}\end{array}$} \\
\hline & & مo & 10 & $m=1$ & مטו & 10 & $m=1$ & 10 & 10 & $\mathbf{m = 1}$ \\
\hline DICHLOAOETHYLENE, 1,2-C. & $156-59-2$ & & & $3.7 E-01$ & & & & & & \\
\hline DICHLOEOETHYLENE, 1.2-T- & $156-60-5$ & & & 7.3E-01 & & & & & & \\
\hline DCHLONOMETHANE & $75-02-2$ & $1.1 E+\infty$ & $1.1 \mathrm{E}-02$ & $2.2 E+\infty$ & & & $8.3 E+\infty$ & & & $1.7 E+\infty$ \\
\hline DHCHLONOFHENOL, 2.4 & $120-83-2$ & & & 1.1E-01 & & & & & & \\
\hline $\begin{array}{l}\text { DICHLONOPHENOXYNOUTYRICACTD. } \\
\text { A-(2.4- }\end{array}$ & 92-82-6 & & & 2.9E-01 & & & & & & \\
\hline DICHLONOPROPANE, 1.2- & ne-87.5 & 1.3E-01 & $1.3 \mathrm{E}-03$ & & & & $1.1 E-02$ & & & \\
\hline DICHLOMOPAOPANOL, 2.3. & $616-23-9$ & & & 1.1E-01 & & & & & & \\
\hline DICHLOROPROPENE, 1,3. & S42-75-6 & $4.7 E-02$ & 4.7E-04 & I.1E-02 & $1.7 E-02$ & $1.7 E-04$ & $5.6 E-02$ & $1.3 \mathrm{E}-02$ & $1.3 E-04$ & 9.1E-03 \\
\hline Dichlonvos & 62.73 .7 & $2.9 E-02$ & 2.9E-04 & 2.9E-02 & & & & & & \\
\hline DICYCLOPENTADIENE & $77.73-6$ & & & $1.1 E+\infty$ & & & $5.65-04$ & & & $5.6 E-04$ \\
\hline DIEDRan & $60.57-1$ & S.3E-N & $5.3 E-66$ & $1.8 E-03$ & & & & & & \\
\hline DEETHYL PHTHALATE & 4a-66-2 & & & $2.9 E+01$ & & & & & & \\
\hline $\begin{array}{l}\text { DAETHYLENE GLYCOL MONOETHYL. } \\
\text { ETHER }\end{array}$ & $111-90-0$ & & & 7.3E+01 & & & & & & \\
\hline DIETHYLFORMAMADE & 617.84 .5 & & & $4.0 E-01$ & & & & & & \\
\hline DAETHYLSTILESTEROL. & 36-53-1 & $1.8 E-06$ & $1.8 E-08$ & & & & & & & \\
\hline DIFENZOQUAT & $43222-48-6$ & & & $2.96+\infty$ & & & & & & \\
\hline DHFUBENZURON & 35367.38-5 & & & 7.3E-01 & & & & & & \\
\hline DHSOPROPYL METHYLPHOSPHONATE & $1445.75-6$ & & & $2.9 E+\infty$ & & & & & & \\
\hline DMETHIFN & $55290-64-7$ & & & 7.3E-01 & & & & & & \\
\hline DIMETHOATE & $60.51-5$ & & & $7.3 E-03$ & & & & & & \\
\hline DIMETHOXYBENZIDINE, 3.3'- & 119.904 & 6.1E-01 & $6.1 E-03$ & & & & & & & \\
\hline DIMETHYLANIUNE HCL, 2,4- & $21436-96-4$ & $1.5 E-02$ & $1.5 E-04$ & & & & & & & \\
\hline
\end{tabular}


Table D.2. (comtinned)

\begin{tabular}{|c|c|c|c|c|c|c|c|c|c|c|}
\hline \multirow[b]{2}{*}{ Chemieal } & \multirow[b]{2}{*}{ CASRN } & \multicolumn{3}{|c|}{ Ingestion $(m g / L)$} & \multicolumn{3}{|c|}{ Inholation (magh) } & \multicolumn{3}{|c|}{$\begin{array}{c}\text { Ingeation + Inhalation } \\
(m g / L)^{6}\end{array}$} \\
\hline & & 10 & 10 & $m=1$ & 10 & 10 & $m=1$ & مo & هo & $m=1$ \\
\hline DMETHYYMNMUNE, 2.4 & $95-60-1$ & $1.1 E-02$ & $1.1 E-04$ & & & & & & & \\
\hline DIMETHYYMANIUNE, N.N- & $121-69.7$ & & & $7.3 E-02$ & & & & & & \\
\hline DIMETHYYLEEZZIDINE, 3,3'. & $119-93-7$ & 9.3E-04 & $9.3 E-06$ & & & & & & & \\
\hline DMETHYLPORMAMADE & $6-12-2$ & & & $3.7 E+\infty$ & & & & & & \\
\hline DMEETHYUHYDRAZINE, 1,1- & $57.14-7$ & 3.3E-63 & 3.3E-0s & & & & & & & \\
\hline DIMETHYYPHENOL, 2,4- & $105-67-9$ & & & $7.3 E-01$ & & & & & & \\
\hline DAMETHYYPHENOL, 2,6. & $576-26-1$ & & & $2.2 E-02$ & & & & & & \\
\hline DIMETHY TPHENOL, 3.4- & $95-65-8$ & & & 3.7E-02 & & & & & & \\
\hline DIMETHY YPTHALATE & $131-11-3$ & & & 3.7E+01 & & & & & & \\
\hline DMMETHYTTEREPHTHALATE & $120-61-6$ & & & $3.7 E+\infty$ & & & & & & \\
\hline DINIRO-CYCLOHEXYL PHENOL, 4,6- & $131-69-5$ & & & $7.3 E-02$ & & & & & & \\
\hline DINITROAENZENE, 1.2- & $528-29.0$ & & & $1.5 E-02$ & & & & & & \\
\hline DINITRODENZENE, 1,3- & $99-65-0$ & & & 3.7E-03 & & & & & & \\
\hline DINITROEENZENE, 1,4- & $100-25-4$ & & & $1.5 E-02$ & & & & & & \\
\hline DINITROFHENOL, 2,4. & 51-28-5 & & & 7.3E-02 & & & & & & \\
\hline DINITROTOLUENE, 2.4. & $121-14-2$ & $1.3 E-02$ & $1.3 E-04$ & & & & & & & \\
\hline DINITROTOLUENE, 2.6- & $\cos -20-2$ & $1.3 \mathrm{E}-02$ & $1.3 \mathrm{E}-04$ & & & & & & & \\
\hline DinOSEB & $88-85-7$ & & & 3.7E-02 & & & & & & \\
\hline DROXANE, 1,4- & $123-91-1$ & $7.7 E-01$ & $7.7 E-03$ & & & & & & & \\
\hline DIPHENAMAD & 957.51 .7 & & & $1.1 E+\infty$ & & & & & & \\
\hline DifHentaAmine & $122-39-4$ & & & $9.1 \mathrm{E}-01$ & & & & & & \\
\hline DIPHENYUHYYRAZINE, 1.2. & $122-66-7$ & $1.1 \mathrm{E}-02$ & $1.1 E-04$ & & & & & & & \\
\hline DHQUAT & $25-00.7$ & & & $8.0 E-02$ & & & & & & \\
\hline
\end{tabular}


Table D.2. (continued)

\begin{tabular}{|c|c|c|c|c|c|c|c|c|c|c|}
\hline \multirow[b]{2}{*}{ Chemical } & \multirow[b]{2}{*}{ CASRN } & \multicolumn{3}{|c|}{ Ingestion (mgh) } & \multicolumn{3}{|c|}{ Inhalation (mgh) } & \multicolumn{3}{|c|}{$\begin{array}{c}\text { Inseation + Inhalation } \\
(m g h)^{\circ}\end{array}$} \\
\hline & & م1 & 10 & $\mathbf{m = 1}$ & م10 & مo & $\mathbf{m}=1$ & 100 & 100 & $\mathbf{m = 1}$ \\
\hline DARECT ELACK 38 & 1937-37.7 & 9.9E-04 & $9.9 E-06$ & & & & & & & \\
\hline DARECT DUE 6 & $2602-46-2$ & 1.1E-03 & 1.1E-0s & & & & & & & \\
\hline DIRECT BROWN gs & $16071-86-6$ & $9.2 E-04$ & $9.2 E-06$ & & & & & & & \\
\hline DAsULfotion & 2xa-0ent & & & $1.5 E-03$ & & & & & & \\
\hline DRURON & $33 a-54-1$ & & & $7.3 \mathrm{E}-02$ & & & & & & \\
\hline DODINE & $2439-10-3$ & & & 1.SE-01 & & & & & & \\
\hline ENDOSULFAN & $115-28-7$ & & & 1.0E-03 & & & & & & \\
\hline ENDOTHALL & $145-73-3$ & & & 7.3E-01 & & & & & & \\
\hline ENDRIN & $72-20-8$ & & & 1.1E-02 & & & & & & \\
\hline EACHLOAOHYDRIN & $106-89-8$ & 8.6E-01 & 8.6E-03 & & S.4E-01 & S.4E-03 & 2.8E-03 & 3.3E-01 & 3.3E-03 & \\
\hline EPTC & 759.944 & & & $9.1 E-01$ & & & & & & \\
\hline ETHEPHON & $16672-87-0$ & & & $1.8 E-01$ & & & & & & \\
\hline ETHON & $563-12-2$ & & & $1.8 \mathrm{E}-02$ & & & & & & \\
\hline ETHOXYETHANOL ACETATE, 2 - & 111.15 .9 & & & $1.1 E+01$ & & & & & & \\
\hline ETHOXYETHANOL $2-$ & $110-80.5$ & & & $1.5 E+01$ & & & & & & \\
\hline ETHYL ACETATE & $141-78-6$ & & & $3.3 \mathrm{E}+01$ & & & & & & \\
\hline ETHYL ACRYATE & 140-82-5 & $1.8 E-01$ & $1.8 E-03$ & & & & & & & \\
\hline ETHYL CHLOPADE & $75-00-3$ & & & & & & $2.8 E+01$ & & & \\
\hline ETHYL ETHER & 60.29 .7 & & & $7.3 E+\infty$ & & & & & & \\
\hline ETHY, METHACRYLATE & $97-63-2$ & & & $3.3 E+\infty$ & & & & & & \\
\hline ETHYLP-NITROPHENYL PHOSPHONATE & $2104-64-5$ & & & 3.7E-0A & & & & & & \\
\hline ETHYLSENZENE & $100-414$ & & & $3.7 E+\infty$ & & & $2.8 E+\infty 0$ & & & $1.6 E+\infty 0$ \\
\hline ETHYLENE CYANOHYDRIN & $109.78-4$ & & & $1.1 E+01$ & & & & & & \\
\hline
\end{tabular}


Table D.2. (continned)

\begin{tabular}{|c|c|c|c|c|c|c|c|c|c|c|}
\hline \multirow[b]{2}{*}{ Chemical } & \multirow[b]{2}{*}{ CASRN } & \multicolumn{3}{|c|}{ Irgestion (ma/L) } & \multicolumn{3}{|c|}{ Inbulation $(\mathrm{mg} / \mathrm{L})$} & \multicolumn{3}{|c|}{$\begin{array}{c}\text { Insestion + Inhalation } \\
(\operatorname{mg} /)^{6}\end{array}$} \\
\hline & & 10 & 10 & $\mathbf{m = 1}$ & مo & 0 & $m=1$ & مص1 & o & $n=1$ \\
\hline ETHYLENE DUAMNE & 107-15.3 & & & 7.3E-01 & & & & & & \\
\hline ETHYLENE GLYCOL & 107.21 .1 & & & $7.3 \mathrm{E}+01$ & & & & & & \\
\hline $\begin{array}{l}\text { ETHYLENE OLYCOL MONOEUTYL } \\
\text { ETHER }\end{array}$ & $111-76-2$ & & & & & & & & & \\
\hline ETHYLENE OXIDE & $75-21-8$ & 8.3E-03 & 8.3E-05 & & $6.5 E-03$ & 6.5E-0S & & $3.7 \mathrm{E}-03$ & 3.7E-OS & \\
\hline ETHYLENE THOUREA & $96-45-7$ & $1.4 E-02$ & $1.4 E-04$ & 2.9E-03 & & & & & & \\
\hline ETHYLPHTHALYL ETHYL OLYCOLATE & $84-72-0$ & & & $1.1 E+02$ & & & & & & \\
\hline EXPRESS & $101200-48-0$ & & & 2.9E-01 & & & & & & \\
\hline FENAMAPHOS & $22224-92-6$ & & & 9.1E-03 & & & & & & \\
\hline FENPROPATHERN & $39515-41.8$ & & & $1.8 E-02$ & & & & & & \\
\hline FWOMETURON & $2164-17.2$ & & & 4.7E-01 & & & & & & \\
\hline FWORANTHENE & $20064-0$ & & & $1.5 E+\infty$ & & & & & & \\
\hline FWORENE & 86-73-7 & & & $1.5 E+\infty$ & & & & & & \\
\hline FWORIDE & $16924-48-8$ & & & $2.2 E+\infty$ & & & & & & \\
\hline FUORINE & $m 782-41-4$ & & & $2.2 E+\infty$ & & & & & & \\
\hline FWRIDONE & $59756-60-4$ & & & $2.9 E+\infty$ & & & & & & \\
\hline FURPRMMADOL & $56+25-91-3$ & & & 7.3E-01 & & & & & & \\
\hline FUTOLANIL & $66332-96-5$ & & & $2.2 E+\infty$ & & & & & & \\
\hline FUVAUNATE & 69409-94.5 & & & $3.7 E-01$ & & & & & & \\
\hline FOLPET & 133-07.3 & $2.4 E+\infty$ & 2.4E-02 & $3.7 E+\infty$ & & & & & & \\
\hline FOMESAFEN & $72178-02-0$ & $4.5 E-02$ & 4.5E-04 & & & & & & & \\
\hline FONOFOS & $2 \times 4-22-9$ & & & $7.3 E-02$ & & & & & & \\
\hline FORMALDEHYDE & $50-000$ & & & $7.3 E+\infty$ & & & & & & \\
\hline FORMIC ACID & 64-18-6 & & & $7.3 E+01$ & & & & & & \\
\hline
\end{tabular}




\section{Table D.2. (contimed)}

\begin{tabular}{|c|c|c|c|c|c|c|c|c|c|c|}
\hline \multirow[b]{2}{*}{ Chemical } & \multirow[b]{2}{*}{ CASRN } & \multicolumn{3}{|c|}{ Investion (ma/l) } & \multicolumn{3}{|c|}{ Inhalation (manh) } & \multicolumn{3}{|c|}{$\begin{array}{c}\text { Inseation + Imhalation } \\
(m g h)^{\circ}\end{array}$} \\
\hline & & 10 & מש & $\mathbf{m = 1}$ & مט1 & 100 & $=1$ & 100 & 10 & $\mathbf{m}=1$ \\
\hline POSETYLAL. & $39148-24-8$ & & & $1.1 E+02$ & & & & & & \\
\hline FURAN & 1100099 & & & $3.75-02$ & & & & & & \\
\hline FURAZOUIDONE & 67-45-8 & 2.25-03 & $2.2 E-05$ & & & & & & & \\
\hline FURFURAL. & 92-01-1 & & & 1.1E-01 & & & & & & \\
\hline FURTUM & $531-82.8$ & 1.7E-04 & $1.75-06$ & & & & & & & \\
\hline FURMECYCLOX & $60568-05-0$ & $2.0 \mathrm{E}-01$ & 2.8E-03 & & & & & & & \\
\hline OLWFOSINATE-AMAMONIUM & $77162-02-2$ & & & $1.5 E-02$ & & & & & & \\
\hline oLrcidrt. & $765-34-4$ & & & 1.5E-02 & & & & & & \\
\hline OLYPHOSATE & 1071-83-6 & & & $3.7 E+\infty$ & & & & & & \\
\hline GOAL & $42874-03-3$ & & & 1.1E-01 & & & & & & \\
\hline HALOXYFOP-METHYY & $60005-60.2$ & & & $1.2 E-03$ & & & & & & \\
\hline HARMONY & 79277.27 .3 & & & 4.7E-01 & & & & & & \\
\hline HEPTACHLOR & $26-4-8$ & 1.9E-03 & $1.9 E-05$ & $1.0 E-02$ & & & & & & \\
\hline HEPTACHLOR EPOXIDE & 1024.57.3 & 9.4E-04 & 9.4E-06 & 4.7E-04 & & & & & & \\
\hline HEXABROMODENZENE & $87.82-1$ & & & 7.3E-02 & & & & & & \\
\hline HEXACHLORODENZENE & $118-74-1$ & S.3E-03 & $5.3 E-05$ & $2.96-02$ & & & & & & \\
\hline HEXACHLOROBUTADIENE & 87-68-3 & 1.1E-01 & 1.1E-03 & 7.3E-02 & & & & & & \\
\hline HEXACHLOROCYCLOHEXANE, ALPHA. & $319-46-6$ & 1.4E-03 & $1.4 E-05$ & & & & & & & \\
\hline HEXACHLOROCYCLOHEXANE, BETA- & $319-25-7$ & 4.7E-03 & 4.7E-05 & & & & & & & \\
\hline HEXАCHLOROCYCLOHEXANE, OAMMA. & 58-89-9 & 6.6E-03 & $6.6 E-05$ & $1.1 E-02$ & & & & & & \\
\hline $\begin{array}{l}\text { HEXACHLOROCYCLOHEXANE, } \\
\text { TECHNICAL }\end{array}$ & $600-73.1$ & 4.7E-03 & 4.7E-05 & & & & & & & \\
\hline HEXАCHLOROCYCLOFENTADIENE & $77-47-4$ & & & 2.6E-01 & & & & & & \\
\hline
\end{tabular}


Table D.2. (continued)

\begin{tabular}{|c|c|c|c|c|c|c|c|c|c|c|}
\hline \multirow[b]{2}{*}{ Chemieal } & \multirow[b]{2}{*}{ CASRN } & \multicolumn{3}{|c|}{ Inzestion (m, } & \multicolumn{3}{|c|}{ Inhalation (man) } & \multicolumn{3}{|c|}{$\begin{array}{c}\text { In wation }+ \text { Inhalation } \\
(m, n)^{b}\end{array}$} \\
\hline & & مق1 & مه1 & $\mathbf{m = 1}$ & مق1 & مع1 & Eer & 10 & معi & nel \\
\hline $\begin{array}{l}\text { HEXACHLOAODHENZO-P.DLOXIN } \\
\text { MEXTURE }\end{array}$ & $19400-74-3$ & 1.4E-66 & 1.4E-65 & & & & & & & \\
\hline HEXACHLOROETHANE & $67-72-1$ & 6.1E-01 & 6.1E-03 & 3.7E-02 & & & & & & \\
\hline HEXACHLOROPHE'ंE & $70-30-4$ & & & $1.1 E-02$ & & & & & & \\
\hline $\begin{array}{l}\text { HEXAHYDRO-1,3,5-TMNITIRO-1,3,5- } \\
\text { TRIAZINE }\end{array}$ & $121-82-4$ & $7.7 \mathrm{E}-02$ & 7.TE-O4 & 1.1E-01 & & & & & & \\
\hline HEXANE. $N$ & $110-54-3$ & & & $2.2 E+\infty 0$ & & & $5.6 E-01$ & & & 4.4E-01 \\
\hline HEXAZINONE & $51235-04-2$ & & & $1.2 E+\infty 0$ & & & & & & \\
\hline HYDRAZINE & $302-01-2$ & 2.8E-03 & 2.0E-05 & & & & & & & \\
\hline HYDRAZINE SULFATE & $10034-93-2$ & 2.8E-03 & 2.0E-0S & & & & & & & \\
\hline HYDROGEN CHLORDE & $7647-01-0$ & & & & & & & & & \\
\hline HYDROOEN CYANIDE & $74-90-8$ & & & 7.3E-01 & & & & & & \\
\hline HYDROGEN SULFIDE & $7783-06-4$ & & & $1.1 E-01$ & & & & & & \\
\hline HYDROQUINONE & $123-31-9$ & & & $1.5 E+\infty 0$ & & & & & & \\
\hline mazauL & $35554-44-0$ & & & 4.7E-01 & & & & & & \\
\hline MazAQUIN & $81335-37.7$ & & & $9.1 E+\infty 0$ & & & & & & \\
\hline INDENO(1,2,3-CD)PYRENE & 193-39-5 & $1.2 E-02$ & $1.2 E-04$ & & & & & & & \\
\hline IPAODIONE & $36734-19-7$ & & & $1.5 E+\infty$ & & & & & & \\
\hline ISOBUTYL ALCOHOL & $78-83.1$ & & & $1.1 E+01$ & & & & & & \\
\hline ISOPHORONE & n-59-1 & $2.1 E+\infty$ & $2.1 E-02$ & $1.3 E+\infty$ & & & & & & \\
\hline ISOPROPALUN & $33820-53.0$ & & & S.SE-01 & & & & & & \\
\hline ISOXABEN & $82558-50-7$ & & & $1.8 E+\infty 0$ & & & & & & \\
\hline KARATE & 91465-08-6 & & & 1.0E-01 & & & & & & \\
\hline KERB & 23950-58-5 & & & $2.7 E+\infty 0$ & & & & & & \\
\hline
\end{tabular}


Tabie D.2. (comtineed)

\begin{tabular}{|c|c|c|c|c|c|c|c|c|c|c|}
\hline \multirow[b]{2}{*}{ Chemien } & \multirow[b]{2}{*}{ CASRN } & \multicolumn{3}{|c|}{ Ingestion (mg/L) } & \multicolumn{3}{|c|}{ Inhalation (manh) } & \multicolumn{3}{|c|}{$\begin{array}{c}\text { Ingestion + Imhalation } \\
(m a / L)^{\circ}\end{array}$} \\
\hline & & مo & مט & $\mathbf{m}=\mathbf{1}$ & م0 & o & $m=1$ & مו & 10 & $=1$ \\
\hline LACTOFES & $77501-63-4$ & & & $7.3 \mathrm{E}-02$ & & & & & & \\
\hline InNURON & $330.55-2$ & & & $7.3 \mathrm{E}-02$ & & & & & & \\
\hline LONDAX & $23055-99-6$ & & & $7.3 E+\infty$ & & & & & & \\
\hline MaLATHion & $121-75-5$ & & & 7.3E-01 & & & & & & \\
\hline MALEC ANHYYREDE & $100-31-6$ & & & $3.7 E+\infty$ & & & & & & \\
\hline MALEC ETYDRAZIDE & 123-33-1 & & & $1.8 E+01$ & & & & & & \\
\hline MALONONITRLE & $109-77-3$ & & & 7.3E-04 & & & & & & \\
\hline MnNCOZEP & $8018-01-7$ & & & $1.1 E+\infty$ & & & & & & \\
\hline MANED & $12427-38-2$ & & & $1.0 E-01$ & & & & & & \\
\hline MANOANEAE & 7439.96-5 & & & $3.7 E+\infty$ & & & & & & \\
\hline MCPA & 24.746 & & & $1.0 E-02$ & & & & & & \\
\hline MCPB & 94-81-5 & & & 3.7E-01 & & & & & & \\
\hline MCPP & $93-65-2$ & & & $3.7 E-02$ & & & & & & \\
\hline MEPHOSFOLAN & $950-10.7$ & & & $3.3 E-03$ & & & & & & \\
\hline MEPRQUAT CHLORIDE & $24307-26-4$ & & & $1.1 E+\infty$ & & & & & & \\
\hline MERCURY, INOROANIC & 7439.97 .6 & & & $1.1 E-02$ & & & & & & \\
\hline MERPHOS & 1so-sa-s & & & $1.1 E-03$ & & & & & & \\
\hline MERPHOS OXIDE & $78-48-8$ & & & 1.1E-03 & & & & & & \\
\hline METALATYL & 57037-19-1 & & & $2.2 E+\infty$ & & & & & & \\
\hline METHACKYLONITRLE & $126-96-7$ & & & $3.7 E-03$ & & & 1.9E-03 & & & 1.3E-03 \\
\hline METHAMEDOPHOS & $10265-92-6$ & & & $1.8 E-03$ & & & & & & \\
\hline METHANOL & $67.56-1$ & & & $1.8 E+01$ & & & & & & \\
\hline METHIDATHION & $950-37-8$ & & & $3.7 E-02$ & & & & & & \\
\hline
\end{tabular}


Table D.2. (contimued)

\begin{tabular}{|c|c|c|c|c|c|c|c|c|c|}
\hline \multirow[b]{2}{*}{ Chemical } & \multirow[b]{2}{*}{ CASRN } & \multicolumn{3}{|c|}{ Ingestion (mg/L) } & \multicolumn{3}{|c|}{ Inhabtotion (mg/l) } & \multicolumn{2}{|c|}{$\begin{array}{c}\text { Investion + Inhaliation } \\
(\operatorname{mg} h)^{\circ}\end{array}$} \\
\hline & & 10 & 10 & $m=1$ & r & مo & $\mathbf{m = 1}$ & 10 & $\mathbf{m = 1}$ \\
\hline METHOMY & $16752-77.5$ & & & 9.1E-01 & & & & & \\
\hline METHOXY-S-MITROANIUNE, 2 - & 9e-se-2 & 1.9E-01 & $1.9 \mathrm{E}-03$ & & & & & & \\
\hline METHOXYCHIOR & $72-43-5$ & & & 1.8E-01 & & & & & \\
\hline METHOXYETHANOL ACETATE, 2 - & $110-496$ & & & 7.3E-02 & & & & & \\
\hline METHOXYETHUNOL 2- & $100-864$ & & & $1.5 E-01$ & & & & & \\
\hline METHYL ACETATE & $79-20.9$ & & & $3.7 E+01$ & & & & & \\
\hline METHYL ACRYLATE & 96-33-3 & & & $1.1 E+\infty$ & & & & & \\
\hline METHYL ETHYL KETONE & 70-93-3 & & & $1.8 E+\infty$ & & & $2.8 E+\infty$ & & $1.1 E+\infty$ \\
\hline METHYL ASOBUTYL KETONE & $108-10-1$ & & & $1.8 E+\infty$ & & & $2.2 E-01$ & & $2.0 E-01$ \\
\hline METHYL MERCURY & $22967-92-6$ & & & $1.1 E-02$ & & & & & \\
\hline METHYL METHACRYATE & 20-62.6 & & & $2.9 E+\infty$ & & & & & \\
\hline METHYL PARATHON & $298-000$ & & & $9.1 \mathrm{E}-03$ & & & & & \\
\hline METHYLL STYRENE (MIXED ISOMERS) & $25013.15-4$ & & & 2.2E-01 & & & & & \\
\hline METHYL-S-NITROANIUNE, 2- & 99-55.8 & $2.6 E-01$ & $2.6 \mathrm{E}-03$ & & & & & & \\
\hline METHYLANIUNE HYDROCHLORIDE, 2 - & $636-21-5$ & $4.7 E-02$ & 4.7E-04 & & & & & & \\
\hline METHYLENE CHLORADE & $75-09.2$ & $1.1 E+\infty$ & $1.1 E-02$ & $2.2 E+\infty$ & & & $8.3 E+\infty$ & & $1.7 E+\infty$ \\
\hline $\begin{array}{l}\text { METHYLENE-EISS-CHLOROANIUNE. } \\
\text { 4.4:- }\end{array}$ & $101-14-4$ & $6.6 \mathrm{E}-02$ & $6.6 E-04$ & $2.6 \mathrm{E}-02$ & & & & & \\
\hline $\begin{array}{l}\text { METHYLDNE-BLSON,N-DNMETHYL } \\
\text { ANIUNE, 4.4:- }\end{array}$ & $101-61-1$ & $1.9 \mathrm{E}-01$ & $1.95-03$ & & & & & & \\
\hline METHYYLENEASBENZENAMANE, 4.49- & $101-77-9$ & 3.4E-02 & 3.4E-04 & & & & & & \\
\hline $\begin{array}{l}\text { METHYLENEDIPHENYL ISOCYANATE, } \\
\text { 4.4:- }\end{array}$ & $101-68-8$ & & & & & & & & \\
\hline METHYLSTYRENE, ALPHA- & 98-83-9 & & & $2.6 E+\infty 0$ & & & & & \\
\hline
\end{tabular}


Table D.2. (contimed)

\begin{tabular}{|c|c|c|c|c|c|c|c|c|c|c|}
\hline \multirow[b]{2}{*}{ Chemical } & \multirow[b]{2}{*}{ CASRN } & \multicolumn{3}{|c|}{ Ingestion (mg/L) } & \multicolumn{3}{|c|}{ Inhalation (men) } & \multicolumn{3}{|c|}{$\begin{array}{c}\text { Ingeation + Inhalation } \\
\left(m_{i} / L\right)^{6}\end{array}$} \\
\hline & & مص1 & 100 & mel & مו & 100 & $m=1$ & 104 & مе & $\mathbf{m}=\mathbf{1}$ \\
\hline METOLACHLOR & $51212-45-2$ & & & $5.5 E+\infty$ & & & & & & \\
\hline METrabuzan & 21067-64-9 & & & $9.1 E-01$ & & & & & & \\
\hline $\operatorname{mans}$ & 2385-.25-5 & $4.7 E-03$ & 4.TE-0s & & & & & & & \\
\hline MOUNATE & $2212-67-1$ & & & $1.3 E-02$ & & & & & & \\
\hline MOLYhDenum & 7439-.98.7 & & & $1.8 E-01$ & & & & & & \\
\hline MONOCHLOROBUTANES & $25154-42-1$ & & & $1.5 E+01$ & & & & & & \\
\hline NALED & $300-76-5$ & & & $7.3 \mathrm{E}-02$ & & & & & & \\
\hline NAPHTHALENE & $91-20.3$ & & & $1.5 E+\infty$ & & & & & & \\
\hline NAPROPAMADE & $15299-99.7$ & & & $3.7 E+\infty$ & & & & & & \\
\hline MCKE. (METANUC) & $2400-02-0$ & & & $7.3 E-01$ & & & & & & \\
\hline MCKE. RERANERY DUST & NA & & & & & & & & & \\
\hline MCKE. SUBSULFIDE & $12035-72-2$ & & & & & & & & & \\
\hline NITRAPYTEN & $1929-82-4$ & & & $5.5 E-02$ & & & & & & \\
\hline NITATE & 14797-55-8 & & & S.8E+01 & & & & & & \\
\hline NITRIC OXXDE & $10102-43-9$ & & & $3.7 E+\infty$ & & & & & & \\
\hline NITRTE & $14797-65-0$ & & & $3.7 E+\infty$ & & & & & & \\
\hline NIROBENZENE & $98-95-3$ & & & $1.8 E-02$ & & & S.6E-03 & & & 4.3E-03 \\
\hline NITROFURANTOIN & $67-20-9$ & & & $2.6 E+\infty 0$ & & & & & & \\
\hline NITROFURAZONE & $59-87-0$ & $5.7 E-03$ & S.7E-0S & & & & & & & \\
\hline NITROOEN DIOXIDE & $10102-4-0$ & & & $3.7 E+01$ & & & & & & \\
\hline NITROOUANIDINE & $556-88.7$ & & & $3.7 E+\infty$ & & & & & & \\
\hline NITROPROPANE, 2- & $79-46-9$ & $9.0 E-04$ & $9.0 E-06$ & & 2.4E-04 & 2.4E-05 & S.6E-02 & $1.9 \mathrm{E}-04$ & $1.9 E-06$ & \\
\hline NITROSO-DI-N-DUTYLAMaNE, N- & $24-16-3$ & 1.6E-03 & $1.6 E-05$ & & $4.2 E-04$ & $4.2 E-06$ & & $3.3 \mathrm{E}-04$ & 3.3E-06 & \\
\hline
\end{tabular}


Table D.2. (comdinned)

\begin{tabular}{|c|c|c|c|c|c|c|c|c|c|c|}
\hline \multirow[b]{2}{*}{ Chemical } & \multirow[b]{2}{*}{ CASRN } & \multicolumn{3}{|c|}{ Ingestion (mg/L) } & \multicolumn{3}{|c|}{ Inhalation (mg/L) } & \multicolumn{3}{|c|}{$\begin{array}{c}\text { Insection + Imhabation } \\
(m g / L)^{\circ}\end{array}$} \\
\hline & & 10 & مאו & $m=1$ & 10 & 10 & $m=1$ & مטו & 100 & $m=1$ \\
\hline NITROSO-DH-N-ROPYLAMaNE,N- & $621-44-7$ & $1.2 \mathrm{E}-0 \mathrm{0s}$ & $2.2 \mathrm{E}-0 \mathrm{~S}$ & & & & & & & \\
\hline NITROSODEETHANOLAMANE, N- & $1116-54.7$ & $3.06-03$ & 3.0E-0s & & & & & & & \\
\hline NITROSODAETHYLANANE, N. & ss-12-s & S.TE-OS & $5.75-07$ & & & & & & & \\
\hline NImOSODMAETHYYMANE, N- & $62-75-9$ & $1.75-04$ & $1.75-06$ & & & & & & & \\
\hline NITROSODIPHENYLAMaNE, N. & $26-30.6$ & $1.7 E+\infty$ & $1.7 \mathrm{E}-02$ & & & & & & & \\
\hline NITROSOMETHYLETHYLAMANE, N. & 10595-95-6 & $3.9 E-04$ & $3.9 E-06$ & & & & & & & \\
\hline NITROSOPYRROUDINE, N. & 930-5s.-2 & $4.1 E-03$ & 4.1E-0s & & & & & & & \\
\hline NITROTOUVENE, $M$ - & $200-1$ & & & 3.7E-1 & & & & & & \\
\hline NInOTOWENE, O & 32-72-2 & & & 3.7E-O1 & & & & & & \\
\hline NITROTOLENE, P- & $99.99-0$ & & & $3.76-01$ & & & & & & \\
\hline NORFWRnzON & $27314-13-2$ & & & $1.5 E+\infty$ & & & & & & \\
\hline NUSTAR & $85509-19.9$ & & & $2.6 E-02$ & & & & & & \\
\hline OCTABROMODIFHENYL ETHER & $32536-52-0$ & & & 1.1E-01 & & & & & & \\
\hline $\begin{array}{l}\text { OCTAHYDAO-1,3.5.7-TETRANITRO } \\
\text { 1,3.5.7-TETRA }\end{array}$ & $2691+1.0$ & & & $1.8 E+\infty$ & & & & & & \\
\hline $\begin{array}{l}\text { OCTAMETHYUPYROPHOSPHOR. } \\
\text { AMDDE }\end{array}$ & $152-16-9$ & & & $7.3 \mathrm{E}-02$ & & & & & & \\
\hline OCTYL, PHTHNLATE, DA-N. & $117-84-0$ & & & $7.35-01$ & & & & & & \\
\hline ORYZAUN & 1904a-88-3 & & & $1.8 E+\infty$ & & & & & & \\
\hline OXADINZON & $19666-30.9$ & & & $1.8 E-01$ & & & & & & \\
\hline OXAMYL & $23135-22-0$ & & & 9.1E-01 & & & & & & \\
\hline PACLOBUTRAZOL. & $76738-62-0$ & & & $4.7 E-01$ & & & & & & \\
\hline PARAQUAT & 1910-42-5 & & & $1.6 \mathrm{E}-01$ & & & & & & \\
\hline PARATHION & $56-38-2$ & & & $3.7 E-01$ & & & & & & \\
\hline - & & & , & & & & & & ; & - \\
\hline
\end{tabular}


Table D.2. (comineded)

\begin{tabular}{|c|c|c|c|c|c|c|c|c|c|c|}
\hline \multirow[b]{2}{*}{ Chemienl } & \multirow[b]{2}{*}{ CASRN } & \multicolumn{3}{|c|}{ Ingection $(\operatorname{mg} / L)$} & \multicolumn{3}{|c|}{ Inlatation (man) } & \multicolumn{3}{|c|}{ 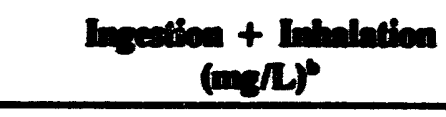 } \\
\hline & & مט & $\omega$ & $m=1$ & n & 100 & $\mathbf{m}=1$ & $\infty$ & 100 & $m=1$ \\
\hline Pevulate & $1114-71-2$ & & & $1.0 E+\infty$ & & & & & & \\
\hline PENDMATtinuN & $\operatorname{sens7-42-1}$ & & & $1.5 E+\infty$ & & & & & & \\
\hline PENTABLOMODIPHENY, ETHER & 32534-81-9 & & & $7.38-02$ & & & & & & \\
\hline PENTACHLONODENZENE & con-ses.s & & & $2.55-2$ & & & & & & \\
\hline PENTACHLORONITROBgnzENE & 22-6e-s & $3.35-02$ & $3.3 \mathrm{E}-\mathrm{OA}$ & $1.15-01$ & & & & & & \\
\hline PENTACHLOROFHENOL. & 87.e6-5 & $7.15-02$ & $7.15-04$ & $1.1 E+\infty$ & & & & & & \\
\hline PERMETHEN & 525045-53-1 & & & $1.2 E+\infty$ & & & & & & \\
\hline PHENANTHRENE" & 25-01-8 & $1.25-03$ & $1.25-05$ & & & & & & & \\
\hline PHENMIEDTFHAM & $13604-63-4$ & & & $9.1 E+\infty$ & & & & & & \\
\hline PHENoL & $100-95-2$ & & & $2.2 E+01$ & & & & & & \\
\hline PHenYlenedulane, 4 & $100-45-2$ & & & $2.25-01$ & & & & & & \\
\hline PHENYLENEDAaLINE, 0 - & 95-s4-s & 1.8E-01 & $1.0 E-03$ & & & & & & & \\
\hline PHENYLENEDLAMaNE, P. & $106-50-3$ & & & $6.9 E+\infty$ & & & & & & \\
\hline PHENYUMERCURAC ACETATE & $62-38-4$ & & & 2.9E-03 & & & & & & \\
\hline PHENYLTHENOL, 2. & $90-43-7$ & $4.4 E+\infty 0$ & $4.4 E-02$ & & & & & & & \\
\hline PHOSATE & $202-02-2$ & & & 7.3E-03 & & & & & & \\
\hline FHOSMET & $232-11-6$ & & & 7.3E-01 & & & & & & \\
\hline PHOSPHaNe & $72003.51-2$ & & & $1.1 E-02$ & & & & & & \\
\hline PHTHAUC ACTD, P. & $100-21-0$ & & & $3.7 E+01$ & & & & & & \\
\hline PHTHAUC ANHYDRADE & essen-9 & & & $7.3 E+01$ & & & & & & \\
\hline PCLORAM & 1918-02-1 & & & $2.6 E+\infty$ & & & & & & \\
\hline MRRMAPHOS-METHYL & 29232-93-7 & & & 3.7E-01 & & & & & & \\
\hline POLYBROMINATED BUPHENYLS & NA & $9.6 E-04$ & $9.6 E-06$ & 2.6E- & & & & & & \\
\hline
\end{tabular}


Table D.2. (contioned)

\begin{tabular}{|c|c|c|c|c|c|c|c|c|c|c|c|}
\hline \multirow[b]{2}{*}{ Chemical } & \multirow[b]{2}{*}{ CASRN } & \multicolumn{3}{|c|}{ Incestion (ma/l) } & \multicolumn{3}{|c|}{ Intulation (ma/l) } & \multicolumn{3}{|c|}{$\begin{array}{c}\text { Ingedien + Intalotion } \\
(m g h)^{\circ}\end{array}$} & \\
\hline & & عפו & مor & $\mathbf{m - 1}$ & מסו & مo & $\mathbf{m - 1}$ & مט & مo & $m=1$ & \\
\hline POLYCHLOMNATED BUPHENYLS & 1336-36-3 & $1.1 E-03$ & $1.1 E-05$ & & & & & & & & \\
\hline POTASSUUM CYANIDE & 151-sa.s & & & $1.28+\infty$ & & & & & & & \\
\hline POTASSUUM SHVER CYANIDE & $505-61-6$ & & & $7.3 E+\infty$ & & & & & & & \\
\hline PROCHLORnz & $67747-00-5$ & $3.7 \mathrm{E}-\mathrm{e} 2$ & S.7E-NA & $3.38-01$ & & & & & & & \\
\hline PROFURAUN & $26399-360$ & & & $2.2 \mathrm{E}-91$ & & & & & & & \\
\hline PROMETON & $1610-12-0$ & & & S.5E-01 & & & & & & & \\
\hline PROMETRYN & $7287-196$ & & & 1.SE-01 & & & & & & & \\
\hline PROPACHLR & 1912-16-7 & & & 4.7E-11 & & & & & & & \\
\hline PROPAMIL & 709-9e-8 & & & 1.8E-01 & & & & & & & \\
\hline PROPAROTE & 2312-35-8 & & & 7.3E-01 & & & & & & & $\varnothing$ \\
\hline PROPAROYL ALCOHOL & 107.19 .7 & & & $7.38-02$ & & & & & & & $\infty$ \\
\hline PropazINe & $139-40-2$ & & & 7.3E-01 & & & & & & & \\
\hline PROPHAM & $122-42-9$ & & & 7.3E-01 & & & & & & & \\
\hline PROPCONAZOLE & 60207-90-1 & & & 4.7E-01 & & & & & & & \\
\hline PROPYLENE GLYCOL. & 57.55 .6 & & & $7.3 E+02$ & & & & & & & \\
\hline $\begin{array}{l}\text { PROPYLENE OLYCOL MONOETHYL } \\
\text { ETHER }\end{array}$ & $1502-024$ & & & $2.6 E+01$ & & & & & & & \\
\hline $\begin{array}{l}\text { PROPYLENE GLYCOL MONOMETHYL } \\
\text { ETHER }\end{array}$ & $107-90-2$ & & & $2.6 E+01$ & & & & & & & \\
\hline PROPYLENE OXIDE & $75-56-9$ & $3.58-02$ & 3.5E-4 & & $1.75-01$ & $1 . T E-03$ & $2.35-02$ & $2.95-02$ & $2.96-04$ & & \\
\hline PUREUTT & 81335-77.5 & & & $9.1 E+\infty$ & & & & & & & \\
\hline PYDRerN & s163a-se-1 & & & 9.1E-01 & & & & & & & \\
\hline PYRENE & $129-00.0$ & & & $1.1 E+\infty$ & & & & & & & \\
\hline PYRADINE & $110-26-1$ & & & $3.75-02$ & & & & & & & \\
\hline V & & & . & & & & & & ' & • & \\
\hline
\end{tabular}



Table D.2. (cometimed)

\begin{tabular}{|c|c|c|c|c|c|c|c|c|c|c|c|}
\hline \multirow[b]{2}{*}{ Chemieal } & \multirow[b]{2}{*}{ CASRN } & \multicolumn{3}{|c|}{ Insestion $(m a / h)$} & \multicolumn{3}{|c|}{ Intalation (ma/L) } & \multicolumn{3}{|c|}{$\begin{array}{c}\text { Inyestion + Imbalation } \\
(m, \Lambda L)^{6}\end{array}$} & \\
\hline & & مט & 10 & $\mathbf{m}=1$ & en & مט & $\mathbf{m}=1$ & مص & 10 & $\mathbf{m = 1}$ & \\
\hline TCDD. 2.3.7.2 & $1746-016$ & $5.75-68$ & $5 . \pi E-10$ & & & & & & & & \\
\hline TCMm & $21564-170$ & & & $1.1 E+\infty$ & & & & & & & \\
\hline TEDUTHUNON & $30014-18-1$ & & & $2.6 E+\infty$ & & & & & & & \\
\hline TEMERHos & 3383-96-5 & & & 7.3E-01 & & & & & & & \\
\hline TEanch. & $5902-51-2$ & & & 4.TE-01 & & & & & & & \\
\hline TEReUfos & $13071-79-9$ & & & 9.1E-4 & & & & & & & \\
\hline TEReUTKKn & eec-50-0 & & & $3 . \pi \mathrm{E}-2$ & & & & & & & \\
\hline TETRACHLOAOSENZENE, 1,2.4.5. & 95-94-3 & & & $1.1 \mathrm{E}-02$ & & & & & & & \\
\hline TETRACHLONOETHANE, 1,1.1.2- & $630-20-6$ & 3.3E-01 & 3.3E-03 & $1.1 E+\infty$ & $8 . \pi E-02$ & I.7E-en & & 6.9E-22 & $6.95-4$ & & \\
\hline TETRACHLOMOETHANE, 1.1.2.2- & 20-34-5 & $4.3 \mathrm{E}-02$ & $4.3 \mathrm{E}-04$ & & $1.16-02$ & 1.1E-A & & $2.05-00$ & .00505 & & $\underset{0}{0}$ \\
\hline TETRACHLOMOETHYLENE & $127-18-4$ & & & $3.7 E-01$ & & & & & & & $\ddot{g}$ \\
\hline TETRACHONOFHENOL, 2,3,4,6. & 58-90-2 & & & $1.1 E+\infty$ & & & & & & & \\
\hline $\begin{array}{l}\text { TETRACHLOROTERERTTHAUC ACID. } \\
\text { 2,3.5,6. DMM }\end{array}$ & $1861-32-1$ & & & $1.2 E+01$ & & & & & & & \\
\hline $\begin{array}{l}\text { TETRACHLOROTOWENE, P. ALPHA. } \\
\text { ALPA, ALPHA- }\end{array}$ & $5216-25-1$ & 4.3E-0A & 4.3E-06 & & & & & & & & \\
\hline TETRAETHYL DITHOOPYROPHOSFHATE & $3699-24-5$ & & & $1.8 E-02$ & & & & & & & \\
\hline THAUUC OXODE & 1314-32-5 & & & $2.6 E-03$ & & & & & & & \\
\hline THALUM ACETATE & $563-62.8$ & & & $3.3 \mathrm{E}-03$ & & & & & & & \\
\hline THALUUM CAFEONATE & 6533-73-9 & & & $2.95-03$ & & & & & & & \\
\hline THAUYUM CHLOADE & $7791.12-0$ & & & $2.95-03$ & & & & & & & \\
\hline THAUUYM SELEIDE & $12039-52-0$ & & & 3.3E-03 & & & & & & & \\
\hline THALUUM SULFATE & $7406-18-6$ & & & $2.95-03$ & & & & & & & \\
\hline THALUMS (I) NTRATE & $10102-45-1$ & & & 3.3E-03 & & & & & & & \\
\hline . & & & + & & & & & & , & - & \\
\hline
\end{tabular}




\section{Table D.2. (combinened)}

\begin{tabular}{|c|c|c|c|c|c|c|c|c|c|c|}
\hline \multirow[b]{2}{*}{ Chanion } & \multirow[b]{2}{*}{ CASMN } & \multicolumn{3}{|c|}{ Investion (mg/L) } & \multicolumn{3}{|c|}{ In'mintion $(\mathrm{m} / \mathrm{h})$} & \multicolumn{3}{|c|}{ 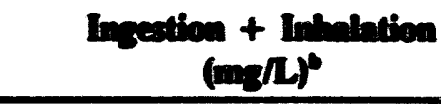 } \\
\hline & & مe & مט & $n=1$ & 10 & 10 & $m=1$ & $\boldsymbol{m}$ & می & Din=1 \\
\hline THOOENCATE & $20200-\pi 16$ & & & 3.7E-01 & & & & & & \\
\hline THOFANOX & 39196-16-4 & & & $1.15-02$ & & & & & & \\
\hline THOPHANATE-METIM & $23 \operatorname{sen}-05-8$ & & & $2.9 E+\infty$ & & & & & & \\
\hline TmRa & $137-20-8$ & & & 1.esen & & & & & & \\
\hline INN AND COMPOUHDS & MA & & & $2.2 E+01$ & & & & & & \\
\hline TOLUIEE & $104-24-3$ & & & $7.3 E+\infty$ & & & $3.1 E+60$ & & & 9.7E-01 \\
\hline TOUUENE-2,4-DLALANE & ss-eat & $2.7 \mathrm{E}-03$ & 2. $\pi E-05$ & & & & & & & \\
\hline TOLUENE-2,5-DHANNE: & es-res & & & $2.2 E+01$ & & & & & & \\
\hline TOUUENE-2,6-DHANE & $223-40-5$ & & & $7.3 E+\infty$ & & & & & & \\
\hline TOUIDINE 0 & $95-53-4$ & $3.5 E-2$ & 3.5E-94 & & & & & & & \\
\hline TOLUDDINE, P- & $100-190$ & $4.5 E-92$ & $4.55-04$ & & & & & & & \\
\hline TOXARHENE & $8001-35-2$ & $7.75-03$ & $7.7 \mathrm{E}-\mathrm{es}$ & & & & & & & \\
\hline TRLOMIETHEN & $66241-25-6$ & & & 2.TE-01 & & & & & & \\
\hline THALATE & 2303-17.5 & & & $4.7 E-01$ & & & & & & \\
\hline TMasuLPURON & 82097-s0-5 & & & 3.TE-01 & & & & & & \\
\hline TREDOMODERZENE, 1,2.4 & $615-54-3$ & & & $1.08-01$ & & & & & & \\
\hline TENTMTH OXIDE & sc-3s-s & & & $1.18-03$ & & & & & & \\
\hline 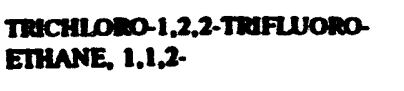 & $x-13-1$ & & & $1.1 E+63$ & & & $8.3 E+01$ & & & 7.8E+01 \\
\hline TWCHLOSOANMUNE HCL, 2,4,6 & $33663-50-2$ & $2.95-01$ & $2.95-03$ & & & & & & & \\
\hline THCHLONOSENZENE, 1,2.4 & $120-12-1$ & & & $3.7 E-01$ & & & $2.5 E-62$ & & & 2.3E-02 \\
\hline THCHLODETHANE, 1.1.1- & $71-55-6$ & & & $3.3 E+\infty$ & & & $2.0 E+\infty$ & & & $1.5 E+\infty$ \\
\hline TMCHIOAOETHANE, 1,1,2- & $7900-5$ & 1.SE-91 & t.5sos & 1.SE-01 & $4.06-02$ & 4.0E-04 & & $3.18-2$ & $3.1 E-04$ & \\
\hline THCHLDOETHYLENE & 79-01-6 & $7.7 \mathrm{E}-11$ & $7.7 E-8 B$ & & $1.3 \mathrm{E}-01$ & $1.3 E-03$ & & $1.15-01$ & 1.1E-03 & \\
\hline
\end{tabular}


Table D.2. (continued)

\begin{tabular}{|c|c|c|c|c|c|c|c|c|c|c|c|}
\hline \multirow[b]{2}{*}{ Chemical } & \multirow[b]{2}{*}{ CASRN } & \multicolumn{3}{|c|}{ Ingestion (man) } & \multicolumn{3}{|c|}{ Intalation (min) } & \multicolumn{3}{|c|}{$\begin{array}{c}\text { Ingection + Inhalation } \\
(\operatorname{men} / L)^{\circ}\end{array}$} & \\
\hline & & 100 & 106 & $m=1$ & مo & 10 & $m=1$ & م & 10 & $m=1$ & \\
\hline TUCEnONOFWOROMETHANE & $75-694$ & & & $1.1 \mathrm{E}+01$ & & & $1.9 E+\infty 0$ & & & $1.7 E+\infty$ & \\
\hline TMCHLOMOFHENOL, 2,4.5- & 95-95-4 & & & $3.7 E+\infty$ & & & & & & & \\
\hline TRECELOXOPHENOL, 2,4.6. & $20-00-2$ & $7.7 \mathrm{E}-01$ & $7 . \pi E-03$ & & & & & & & & \\
\hline $\begin{array}{l}\text { TUCHLONOFHENOXY PROPIONIC ACID. } \\
2(2,4,5 \text { - }\end{array}$ & 33-72-1 & & & $2.95-01$ & & & & & & & \\
\hline $\begin{array}{l}\text { TWCHLONOFHENOXYACERC ACTD. } \\
\text { 2,4.5. }\end{array}$ & $93.76-5$ & & & 3.7E-01 & & & & & & & \\
\hline TWCHLONOPROPANE, 1.1.2. & $520-77 \cdot 6$ & & & $1.8 E-01$ & & & & & & & \\
\hline TMCHLOMOPROPANE, 1.2,3. & $36-18-4$ & & & $2.2 \mathrm{E}-01$ & & & & & & & \\
\hline TMCHLOMOPROPENE, 1.2.3. & $9-19.5$ & & & 1.9E-01 & & & & & & & \\
\hline TRDIPHANE & $50138-00-2$ & & & 1.1E-01 & & & & & & & 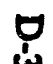 \\
\hline TWETHYYAMANE & $121-4+8$ & & & & & & $1.9 E-02$ & & & & N \\
\hline TEFURAuN & 1582.09 .8 & $1.1 E+\infty$ & $1.1 \mathrm{E}-02$ & $2.7 \mathrm{E}-01$ & & & & & & & \\
\hline TRMMETHYL PHOSPHATE & $312-56-1$ & 2.3E-01 & 2.3E-03 & & & & & & & & \\
\hline TRANIRODENZENE, 1,3.5. & $99.35-4$ & & & $1.8 E-03$ & & & & & & & \\
\hline $\begin{array}{l}\text { TRINTROPHENYLMETHYL } \\
\text { NITRNANE }\end{array}$ & 479-45-1 & & & 3.7E-01 & & & & & & & \\
\hline TRINIROTOUUENE, 2,4,6- & $118-96-7$ & 2.8E-01 & 2.8E-03 & $1.85-02$ & & & & & & & \\
\hline URANTUM (SOLUDLE SALTS) & NA & & & $1.1 E-01$ & & & & & & & \\
\hline VANADIUM FENTOXIDE & 1314-62-1 & & & S. JE-01 & & & & & & & \\
\hline VANADRUM, METALWC & $7400-62-2$ & & & 2.6E-01 & & & & & & & \\
\hline VANADYLSULFATE & $27774-13-6$ & & & 7.3E--1 & & & & & & & \\
\hline VERNOLATE & $1929-77.7$ & & & $3.7 E-02$ & & & & & & & \\
\hline VINCLOZOUN & $\operatorname{son} 71-4-8$ & & & $9.1 E-01$ & & & & & & & \\
\hline , & & & ${ }^{\star}$ & & & & & & > & - & \\
\hline
\end{tabular}




\begin{tabular}{|c|c|c|c|c|c|c|c|c|c|c|}
\hline \multirow[b]{2}{*}{ Cremical } & \multirow[b]{2}{*}{ CASRN } & \multicolumn{3}{|c|}{ Ingection $(m, / L)$} & \multicolumn{3}{|c|}{ Inhalation (man) } & \multicolumn{3}{|c|}{$\begin{array}{c}\text { Insestion + Inhalation } \\
(m g / L)^{6}\end{array}$} \\
\hline & & مטt & $\omega$ & $\operatorname{mel}$ & م' & 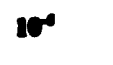 & $\mathbf{m = 1}$ & 10 & 10 & Bat $=1$ \\
\hline VWNYACETATE & 10eeses & & & $3.7 \mathrm{E}+01$ & & & $5.6 \mathrm{~B}-01$ & & & S.5E-01 \\
\hline varr enomide & $\operatorname{ses}-602$ & & & & $2.1 E-02$ & $2.1 \mathrm{E}-\mathrm{an}$ & & & & \\
\hline virm chomese & $75-014$ & $4.55-83$ & 4.5808 & & $7.6 \mathrm{E}-0 \mathrm{~B}$ & 1.6E-0S & & $2.05-00$ & 2.8E-05 & \\
\hline WABFaras & 11-41-2 & & & $1.15-02$ & & & & & & \\
\hline Whitr moshows & $m 23-140$ & & & $7.38-04$ & & & & & & \\
\hline XYLENE, MaXTURE & 1330.20 .7 & & & $7.3 \mathrm{E}+01$ & & & & & & \\
\hline XTENE, M & $100-32-3$ & & & $7.3 E+01$ & & & & & & \\
\hline XYUENE, 0 & $95-47-6$ & & & $7.3 E+01$ & & & & & & \\
\hline ZNC (MIETALUK) & 7400060 & & & $7.3 E+\infty$ & & & & & & \\
\hline ZNAC CYANIDE & $557-21-1$ & & & $1.0 E+01$ & & & & & & \\
\hline ZnNC mospride & 1314-24-7 & & & $1.1 E-02$ & & & & & & \\
\hline ZnNE & $12122-67.7$ & & & $1.8 E+\infty$ & & & & & & \\
\hline
\end{tabular}

- Under residential had wee, riak from surfice water or groundwater contaminants is assumed to be due primarily to direct ingection and to inhalation of volatiles (by aduhas) from houschold waler use. The riaks from these two exposure pathways are combined, and the risk-based concentration in derived to be protective for exposures from both

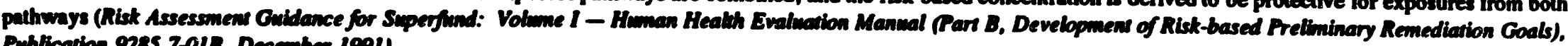
Publication 9285.7-018, December 1991).

- If slope fretors andVor RDs were available for only one pettrway (i.e., ingeation OB inhahation), the lotal for ingeation plus inhalation was not calculated.

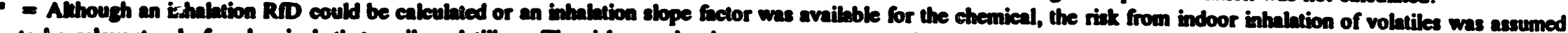
to be relevant only for chemicals that easily voletilize. The riak equation incorporntes a water-air concentration relationahip that is applicable only to chemicals with a

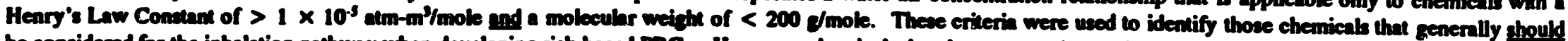
be considered for the inhalation pathway when developing risk-based PRGs. However, chemicals that do not meet these criteria may pose significant site risks (and require riakt based goelb) through volatiles inhalation. The uhimate docision rezanding which contaminants should be considered in the feasibility atudy mest be made on a sitespecific basis following completion of the baseline risk assesument.

- = Same oral slope fector as used for polychlorineted biphenyb.

- = PRG caleubed comsidering New Interin Resion IV Guidune from EPA (received February 11, 1992). The slope factors for chemicals so marked indicate that a loxicity equivalency factor (TEF) method was uned for carcinogenic polyaromatic hydrocarbons (PAHs) based on each compound's relative potency to the potency of benzo(a)pyrene. The following TEFa were used to convert cach PAH slope finctor to an equivalent slope fictor of benzo(a)pyrene (that has a new cancer slope factor of 7.3 (mg/kg/day). identifiod by EPA's CRAVE workgroup]: (1) Benzo(a)pyrene; TEF = 1.0, (2) Benzo(a)anthrncene; TEF $=0.1$, (3) Benzo(b)fuoranthene; TEF = 0.1, (4) 
Table D.2. (continued)

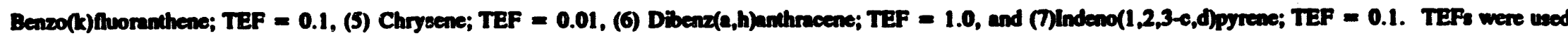
only for the ornl slope fector in the ingeation pathmay.

- = The elope factor for trichlorocthylene has been withdrawn from IRIS and HEAST; however, because this is a common contaninast, the old alope fector has been used to calculate the PRO.

NA $=$ Not avaibble. 

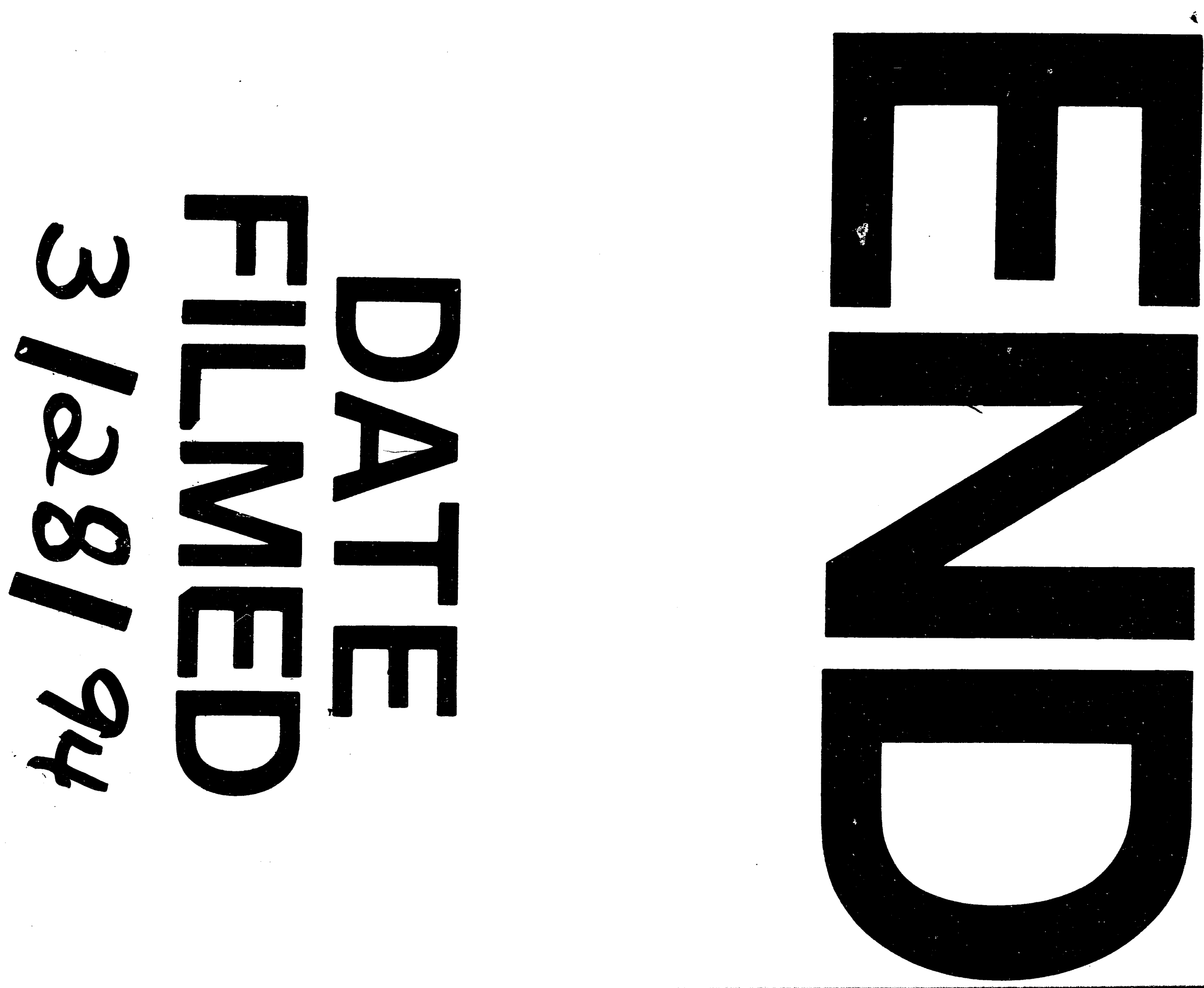
. 